um Glossário Poético

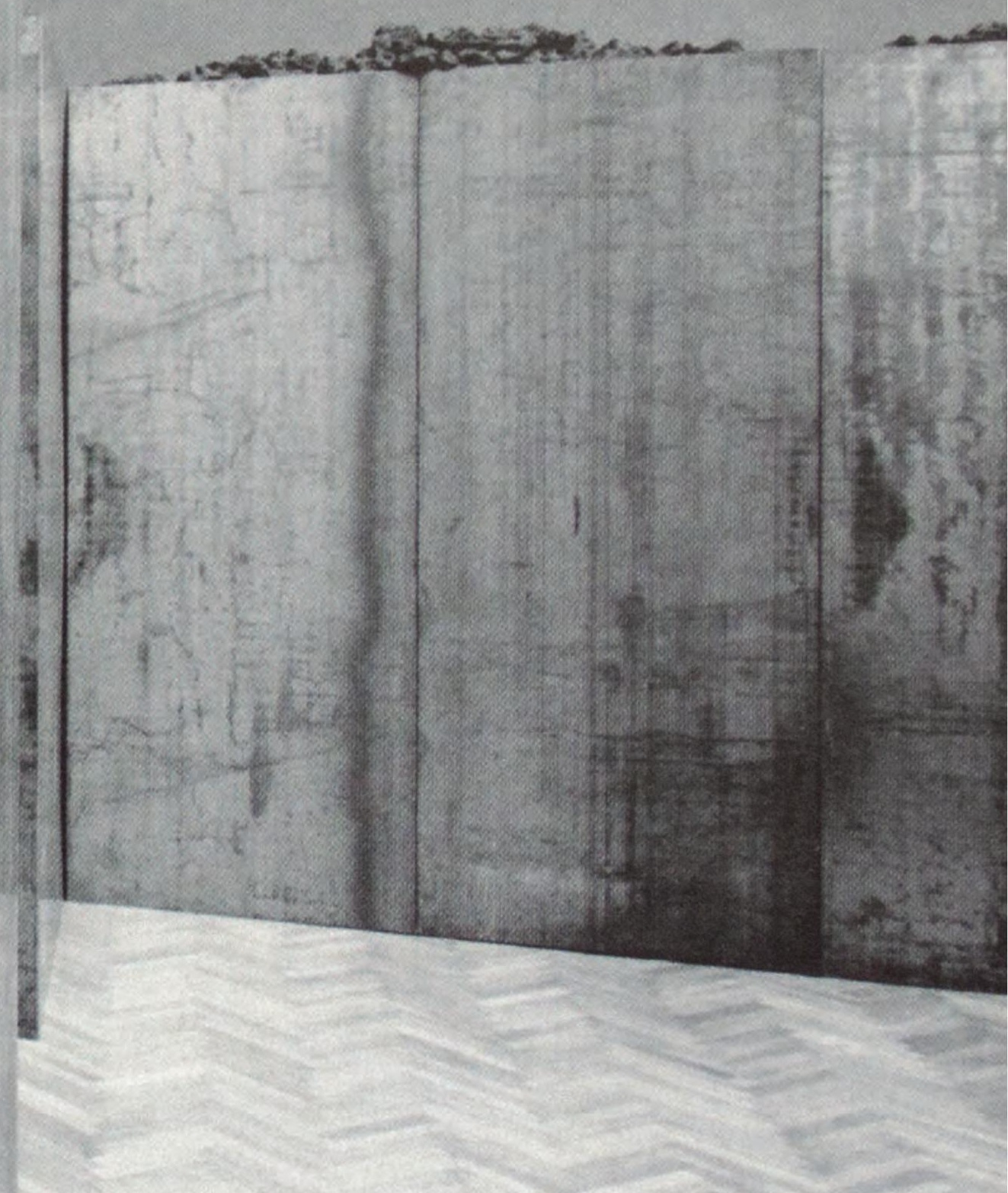

da obradeJannis Kounellis 


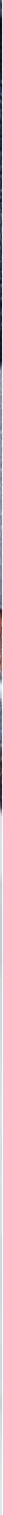




UNIVERSIDADE DE SÃO PAULO

ESCOLA DE COMUNICAÇÕES E ARTES

PROGRAMA DE PÓS-GRADUAÇÃO EM ARTES VISUAIS

Um glossário poético da obra de Jannis Kounellis

Jimson Vilela

São Paulo 

UNIVERSIDADE DE SÃO PAULO

ESCOLA DE COMUNICAÇÕES E ARTES

PROGRAMA DE PÓS-GRADUAÇÃO EM ARTES VISUAIS

\section{Um glossário poético da obra de Jannis Kounellis}

Jimson Vilela

Tese apresentada ao Programa de Pós-Graduação em Artes Visuais, da Escola de Comunicações e Artes, da Universidade de São Paulo, como requisito parcial para a obtenção do título de Doutor em Artes Visuais.

Orientador: Prof. Dr. Mario Celso Ramiro de Andrade 
Autorizo a reprodução e divulgação total ou parcial deste trabalho, por qualquer meio convencional ou eletrônico, para fins de estudo e pesquisa, desde que citada a fonte.

\section{Capa e contracapa:}

Vista da exposição Fannis Kounellis - Ato Único, Galeria Nacional de Arte Moderna, Roma, 2002. Foto: Claudio Abate.

Contraguarda inicial:

Vista da exposição Kounellis, Galeria Giorgio Persano, Turim, 2012. Foto: Michelle Coudray.

Contraguarda final:

Sem título, 1971. Maçarico sobre o piso. Foto: Paolo Mussat Sartor.

Catalogação na Publicação

Serviço de Biblioteca e Documentação

Escola de Comunicações e Artes da Universidade de São Paulo

Dados fornecidos pelo(a) autor(a)

VILELA, Jimson

Um glossário poético da obra de Jannis Kounellis / Jimson Vilela; orientador: Mario Ramiro. --São Paulo, 2020.

342 p.: il.

Tese (Doutorado) - Programa de Pós-Graduação em Artes Visuais Escola de Comunicações e Artes / Universidade de São Paulo.

Bibliografia

Versão original

1. Glossário poético; 2. Kounellis, Jannis (1936-2017); 3. Arte contemporânea; 4. Pintura; 5. Escritos de artistas; 6. Arte Povera; 7. Poéticas visuais; 8. Artes visuais. I. Ramiro, Mario II. Título.

CDD 21. ed. -700 
Vilela, Jimson

\section{Um glossário poético da obra de Jannis Kounellis}

Tese apresentada ao Programa de Pós-Graduação em Artes Visuais, da Escola de Comunicações e Artes, da Universidade de São Paulo, como requisito parcial para a obtenção do título de Doutor em Artes Visuais.

Aprovado em:

Banca Examinadora:

Prof. Dr.

Instituição

Julgamento Assinatura

Prof. Dr.

Instituição

Julgamento Assinatura

Prof. Dr.

Instituição

Julgamento Assinatura

Prof. Dr.

Instituição

Julgamento Assinatura

Prof. Dr.

Instituição

Julgamento Assinatura 

O presente trabalho foi realizado com apoio do CNPq, Conselho Nacional de Desenvolvimento Científico e Tecnológico - Brasil. 


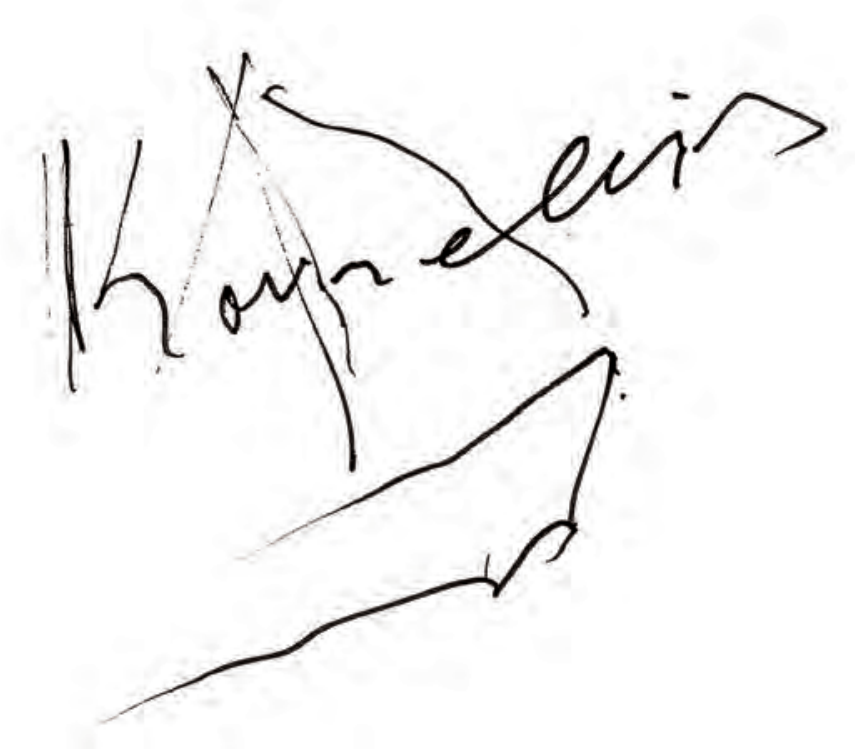


Meus agradecimentos:

Ao Prof. Dr. Mario Ramiro, pela interlocução precisa e atenciosa, pelo exemplo de generosidade intelectual e de dedicação à atividade artística e à docência;

À Profa. Dra. Galciani Neves e ao Prof. Dr. José Spaniol, pelas preciosas críticas e sugestões;

Aos professores, alunos e funcionários do Departamento de Artes Visuais da ECA-USP, em especial à professora Sônia Salzstein, ao professor Luiz Claudio Mubarac, à Karina Andrade, ao Olavo José da Silva, ao Vanderlei Martins de Souza e ao Antonio Henrique Sobrinho;

À Profa. Dra. Dora Longo Bahia, à Profa. Dra. Fernanda Fernandes e ao Prof. Dr. Guilherme Wisnik, pelas aulas;

Ao Prof. Dr. Agnaldo Farias e à Profa. Dra. Glória Ferreira, pelas magníficas conversas;

Aos funcionários do Espaço das Artes e ao seu diretor, João Bandeira;

Aos meus familiares Marcos Vilela, Maria Cândida, Jimson Flávio, Lucy Vilela, Helena Benetti e José Antonio Benetti, pelo apoio incondicional;

À Profa. Dra. Dária Jaremtchuk, Paola Colacurcio, Nilton Bueno e Geraldo Valério, pela gentileza e pelos livros;

Aos funcionários dos arquivos, bibliotecas e instituições visitadas no exterior, em especial ao Vincenzo Rutiglano, à Karolina Chojnowska e à Michelle Coudray, presidente do Archivio Kounellis e viúva do artista e aos amáveis bibliotecários da Universidade de São Paulo;

À Yukie Hori, pela amizade e pela ajuda com o projeto gráfico;

Aos amigos que, de alguma maneira, estiveram presentes nesses quatro anos de pesquisa e trabalho, em especial ao Andrey Zignnatto, ao Lucas Carpinelli, ao Luiz Fabio Antonioli, ao Daniel Rubim, ao Júlio Martins, ao Marco Antonio, ao Erico Marmiroli, ao Antonio Ewbank, ao Pedro Carneiro, à Danielle Abrahamsson, ao Vitor Iwasso, à Alline Nakamura, ao Matias Monteiro, ao Filipe Barrocas, ao Diego Alves e à Amanda Cristina;

Ao João Magalhães, por tudo, em memória. 

Para Liliane Benetti

O escritor diz quase o que tudo deve ser entendido. Na pintura, um vínculo misterioso é estabelecido entre as almas dos assistidos e do espectador.

Eugène Delacroix 



\section{Resumo}

Um glossário poético da obra de Fannis Kounellis parte da análise dos trabalhos e escritos do artista com o intuito de apontar, delinear e compreender o repertório de conceitos, elementos, procedimentos e referências de sua linguagem artística. O glossário poético foi elaborado, nesta tese, como uma ferramenta de aproximação à obra de Jannis Kounellis (1936-2017) e articula um conjunto de verbetes com imagens selecionadas na vasta produção do artista, mapeando a sua poética. Por 56 anos ininterruptos, a produção de Jannis Kounellis teceu labirínticos diálogos com a fundação mítica da pintura; com a história da pintura enquanto arte liberal e seus desdobramentos linguísticos na modernidade; com os contextos políticos e sociais do pós-Segunda Guerra Mundial; e terminou por conceituar a passagem da linguagem pictórica da representação à apresentação. Além do estabelecimento de um panorama da poética de Kounellis, esta tese propõe, por meio do exame da produção do artista, uma reflexão em torno da linguagem artística, suas formas de organização e dinâmicas internas, que, por vezes, retomam e reelaboram problemas inerentes ao campo da arte desde sua conformação. Quando os debates sobre o fim da pintura se amplificaram, Kounellis foi dissonante e não a abandonou: designouse pintor para questionar a natureza da pintura e, em sua prática artística, engendrou uma lógica que entendia a tinta sobre a tela como apenas um dos meios possíveis da pintura. Esta abordagem privilegia a experiência do fazer artístico, ou seja, o debate e a apresentação da obra de Kounellis por meio do glossário poético se dá sob a perspectiva de um artista que pesquisa outro artista.

Palavras-chave: Glossário poético; Jannis Kounellis; arte contemporânea; pintura; escritos de artistas; Arte Povera; poéticas visuais; artes visuais. 



\begin{abstract}
A poetic glossary of Fannis Kounellis work is based on the analysis of the artist's works and writings in order to indicate, outline and understand the repertoire of concepts, elements, procedures and references of his artistic language. In this Thesis, the poetic glossary developed here serves as a tool to approach the work of Jannis Kounellis (1936-2017) and articulates a set of entries with selected images from the artist's vast production, mapping his poetics. For 56 consecutive years, Jannis Kounellis' production wove labyrinthine dialogues with the mythical foundation of painting; with the history of painting as a liberal art and its linguistic developments in modernity; with post-World War II political and social contexts; and ended up conceptualizing the passage of pictorial language from representation to presentation. In addition to establishing a panorama of Kounellis' poetics, this study examines the artist's production to reflect upon his artistic language, forms of organization and internal dynamics, which, at times, reconsider and reelaborate problems inherent to the art field since its conformation. When the debates over the end of painting grew, Kounellis followed his own path and did not abandon it: he called himself a painter to question the nature of painting and, in his artistic practice, devised a specific logic that understood paint on canvas as just a possible means of painting. This approach favors the experience of artistic making, that is, the debate and presentation of Kounellis' work through this poetic glossary takes place from the perspective of an artist who researches artists.
\end{abstract}

Keywords: Poetic glossary, Jannis Kounellis; contemporary art; painting; artist's writings; Arte Povera; visual poetics; visual arts. 



\section{Sumário}

$\begin{array}{ll}\text { Por que Kounellis? } & 19\end{array}$

Kounellis, porque Kounellis $\quad 22$

Um glossário poético da obra de Jannis Kounellis 25

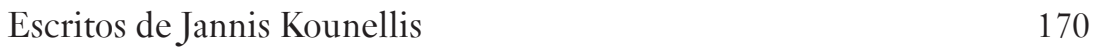

Bibliografia 334

Outros textos não incluídos neste trabalho 340 


\section{Por que Kounellis?}

Em 2016, quando iniciei minha pesquisa junto ao PPGAV, havia uma pergunta para a qual eu buscava, tanto como pesquisador quanto como artista, uma resposta: de que maneira, em quatro anos, eu poderia construir e praticar um glossário poético?

A questão era um desdobramento de minha dissertação de mestrado, na qual meu trabalho de arte e seu processo de criação foram analisados tendo como caixa de ressonância escritos de minha autoria contemporâneos do conjunto de obras estudado. Logo, o objetivo do Doutorado era mapear meu vocabulário de trabalho, para definir quais materiais, formas, técnicas, conceitos e procedimentos eu estava utilizando - e que outros eu poderia usar, tendo em vista um repertório já estabelecido na construção de minha própria dinâmica artística - e, de modo claro e conciso, explanar aos meus interlocutores por meio de verbetes.

Nos dois primeiros anos do Doutorado, paralelamente à dedicação à pesquisa, tive minha primeira experiência como docente no ensino superior, no curso de Artes Visuais da Escola de Belas Artes da Universidade Federal do Rio de Janeiro (EBA-UFRJ), cujo programa era voltado à formação de artistas. Durante minha atuação enquanto professor atentei para a complexa conjuntura da formação do artista, dado que um dos valores qualitativos de uma produção artística, ainda hoje, é a sua singularidade. Nesse período, pautando-me pelos trabalhos e interesses pessoais dos jovens artistas em formação, busquei iniciar e consolidar junto aos alunos um léxico comum que abrangesse os aspectos técnicos, teóricos e históricos mais elementares da arte. Tal tarefa exigia o reconhecimento de similaridades entre as obras e os artistas usados por mim enquanto referência para, no decurso das aulas, apresentar aos estudantes um fio condutor que alinhava todas aquelas experiências particulares sob o conceito de arte, sem, no entanto, encerrá-lo.

No Doutorado, além da pesquisa direcionada ao próprio trabalho de arte, fui estabelecendo contato com escritos de artistas historicamente consolidados na diligência de encontrar nos textos de um artista mais experiente subsídios que me ajudassem na construção de meu glossário poético. Nesse momento, dois artistas me chamavam a atenção pela coerência na articulação de ideias, conceitos e referências: Richard Serra e Jannis Kounellis. Entretanto, a escrita de Kounellis, por sua 
versatilidade na criação de vozes e situações ficcionais, fixou meu interesse, pois enxergava nela semelhanças com a minha escrita e com o tipo de relação que gostaria de arquitetar entre obra e texto.

Existia também outro ponto de atração, a experiência docente de Kounellis na Academia de Artes de Düsseldorf, que, para mim, havia sido guiada pelas mesmas preocupações que eu estava tendo no ínterim de minha atuação como professor. Por conta disso, imediatamente dei início a uma leitura aprofundada dos textos do artista com o intuito de extrair dali indicações que me ajudassem tanto na pesquisa quanto em sala de aula e foi ali que percebi meu objeto de investigação ganhar um novo foco. Pois, ao entrar em contato com escritos de Kounellis, notei que meu objetivo inicial, voltado à criação de um glossário poético de meu fazer artístico, tinha potencial para ser uma ferramenta capaz de mapear, inclusive, a poética de outros artistas. Em outras palavras, a criação de verbetes para dar conta de outras produções se mostrava viável como metodologia, até mesmo no caso de produções artísticas incipientes, tendo em vista que uma das tarefas do professor de artes é promover no jovem artista a tomada de consciência de suas escolhas.

É inegável que a experiência em sala de aula somada ao encontro com os textos de Kounellis contribuiu para formulação da ferramenta do glossário poético para além dos limites de minha prática artista. Contudo, a decisão de abdicar da escrita de um doutorado específico sobre o meu trabalho de arte foi tomada alguns meses após o exame de qualificação, em 2018. Ainda mergulhado na escrita de Kounellis, realizei uma viagem à cidade de Nova York para ver pessoalmente as obras do artista em coleções e museus locais, A escolha por Nova York visava também localizar certas obras de artistas citados por Kounellis, e posteriormente, em 2019, consegui realizar uma nova viagem para a cidade, em que pude levantar mais material e visitar outros acervos. Ao retornar ao Brasil, munido de novas bibliografias e do contato com as obras, informei ao meu orientador o meu desejo de produzir um glossário poético sobre a obra de Jannis Kounellis. O Prof. Dr. Mario Ramiro vislumbrou no trabalho uma possibilidade de contribuição para o debate acadêmico, considerando a relevância da produção de Kounellis para a arte contemporânea. Entretanto, fui advertido sobre a natureza de um Doutorado na área de Poéticas Visuais cuja abordagem investigativa privilegia a experiência do fazer artístico, ou seja, caberia a mim debater e apresentar a obra de Kounellis por meio do glossário poético sob a perspectiva de um artista escrevendo sobre outro artista. 
Após meu período de docência na EBA-UFRJ, retornei à sala de aula como estagiário do Programa de Aperfeiçoamento de Ensino em 2019, na disciplina Prática de Escultura I, cujo docente responsável era o Prof. Dr. Ramiro. Cito essa vivência em sala de aula tutorada por um artista e docente mais experiente, pois julgo que ela contribuiu tanto quanto as reuniões de orientação para a escrita deste trabalho, uma vez que foi presenciando a forma como um artista que domina o vocabulário da arte assume o papel de professor e apresenta os conhecimentos da arte que encontrei os parâmetros exatos para a calibração da escrita e da voz narrativa, dado que o artista também fala por seus materiais, gestos e imagens.

Isto é, a experiência em sala de aula serviu para reiterar que a linguagem do artista não se limita às palavras. Logo, escrever um glossário poético não se restringe ao texto, mas vai além dele e requer a compreensão de que o pensamento verbal na arte está lastreado pela materialização de um raciocínio plástico e todas as etapas do processo artístico estão em questão, da concepção ao registro. Por conta disso, faz-se necessária uma instância imagética junto ao texto para abarcar o que as palavras, por sua natureza, não podem expressar.

Em síntese, o glossário poético é um conjunto de verbetes que articulam e relacionam procedimentos, conceitos, materiais e referências usados por um artista associado às imagens dessa produção, que dialogam com o texto e revelam ao leitor aspectos da obra. E é essa ferramenta que foi utilizada para a escrita deste trabalho.

Feita essa digressão sobre o percurso da pesquisa e seu objeto restame finalizar alguns pontos da apresentação e posicionar este trabalho no contexto atual da pesquisa em arte contemporânea no Brasil, pois espera-se que a ferramenta do glossário poético aqui desenvolvida possa contribuir para a análise da obra de outros artistas independentemente de sua trajetória. 


\section{Kounellis, porque Kounellis}

Nas páginas que se seguem, o leitor irá encontrar um glossário poético da obra de Kounellis constituído por um conjunto de verbetes que apresentam os principais conceitos, materiais e referências artísticas que o artista utilizou em seus 56 anos de trabalho. A escolha dos termos vertidos em verbetes se baseou não apenas na recorrência quantitativa desses, mas igualmente na relevância imagética, técnica e teórica dada pelo artista e sua respectiva fortuna crítica. É parte do glossário uma seleção de imagens das obras de Kounellis que estabelece com o texto uma dinâmica dialética.

Esse compilado de imagens se estende até a segunda seção da Tese, composta por textos do artista traduzidos para o português. Trazer essa coletânea de escritos para este trabalho se fez necessário pela maneira com que Kounellis, em seus textos, articulou seu pensamento crítico e artístico em relação ao seu fazer, relevando uma parcela significativa de seu vocabulário de procedimentos e referências.

No contexto do Doutorado em Artes Visuais, julgo relevante destacar novamente a atividade docente Kounellis, entre 1993 e 2001, na Academia de Artes de Düsseldorf. A dedicação do artista ao ensino e formação das futuras gerações de artistas mostrava um compromisso com a arte e seu campo de pesquisa que ia além da laboração artística solitária no ateliê, sendo a constante articulação de citações e referências artísticas uma das mais notáveis características de Kounellis como artista e professor.

Por fim, antes de passar ao glossário poético, gostaria de posicionar a obra de Kounellis em relação à produção artística internacional, sobretudo a brasileira, de modo a evidenciar pontos de interesse que justificam a pesquisa desse artista mundialmente reconhecido, porém pouco estudado por aqui, ainda mais tendo em vista o número de publicações que abordam ou citam seus contemporâneos americanos.

Como se sabe, a obra de Kounellis está historicamente vinculada à produção italiana da segunda metade da década de 1960, conhecida como Arte Povera. No entanto, não seria um exagero dizer que a produção do artista manteve sua relevância global por um longo período, dada sua participação em quatro edições da Documenta de Kassel 
(1972, 1977, 1982 e 1992) e em nove edições da Bienal de Veneza (1972, 1976, 1978, 1980, 1984, 1988, 1993, 2011 e 2015). Além disso, Kounellis realizou dezenas de exposições individuais nos principais museus do mundo e cenografias para peças de teatro e ópera de importantes diretores, como Carlo Quartucci, Heiner Müller e Pierre Audi.

É sensível que a produção de Kounellis se modificou com o passar do tempo, abdicando de certos materiais para incorporar outros elementos, focalizando algumas questões em determinados períodos, fazendo de cada investigação plástica o alicerce para a seguinte. Porém ele sempre preservou a criação de um ambiente de tensão entre os sentidos do espectador e a obra, enquanto um atributo fundamental de sua poética. Isso é perceptível nos cavalos na galeria l'Attico, nas performances com músicos, no emprego de materiais com odor, no uso de facas e maçaricos, nos pedaços de carne, nas exposições com labirintos e até mesmo no uso do ouro, obras em que o artista busca com frequência a elaboração de uma situação disruptiva na qual o observador é interrogado a respeito de sua presença naquele lugar. Todavia, não se trata meramente de uma confrontação, mas de um gatilho que torna o espectador ciente do contexto no qual ele e a obra estão inseridos.

Nesse sentido, Kounellis estabeleceu um lugar bem distinto da aridez da experiência minimalista e seus respectivos desdobramentos que, em larga maioria, reconhecia a neutralidade do cubo branco, fazendo dele o ambiente privilegiado de uma investigação cujo interesse central era a percepção do espectador.

Com relação à produção brasileira, em especial o neoconcretismo e a geração de 1970, é preciso considerar o contexto de ditadura militar, que reduziu drasticamente as liberdades expressivas dos artistas no ambiente institucional, o que nos anos de 1960, creio, contribuiu para a elaboração de obras que se comportavam como dispositivos para a instauração de espaços de liberdade em paralelo à realidade de controle dos corpos pelo Estado, vide as produções de Lygia Clark, Lygia Pape e Hélio Oiticica e outros. Posteriormente, com o endurecimento do regime, nota-se que os artistas dos anos 1970 desenvolvem em suas práticas temáticas de contestação e denúncia que terminam por alargar o repertório de meios, materiais e lugares de apresentação. Aqui, a performance registrada fotograficamente ocupa um espaço relevante nas obras de Carlos Zílio, Artur Barrio e Cildo Meireles, que por vezes beiram o anonimato. Ou seja, a produção brasileira contemporânea à Arte Povera se estabelece para além das paredes das instituições, tanto 
por conta do contexto de uma ditadura, quanto pelo repertório plástico desenvolvido na época. Logo, essa produção, grosso modo, entre 1960 e 1970, desenvolveu e rompeu com os conceitos de objeto de arte, espaço expositivo e público, ao passo que a preocupação de Kounellis naquele momento era o estabelecimento de um elo conceitualmente estável entre a linguagem da apresentação e a linguagem historicamente consolidada da arte.

Tendo em vista esse breve contexto aqui tecido, acredito que o presente trabalho, Um glossário poético da obra de Fannis Kounellis, pode contribuir, inclusive, para pesquisas cujo objeto esteja relacionado às produções artísticas contemporâneas à Arte Povera. 


\section{Um glossário poético da obra de Jannis Kounellis}

Sem titulo $^{(\mathrm{v})}$ (Cavalo $^{(\mathrm{v})}$ ), obra realizada por Jannis Kounellis no dia 14 de janeiro de 1969 na Galeria l'Attico, Roma. Gerou a imagem ${ }^{(v)}$ mais emblemática da produção artística conhecida como Arte Povera ${ }^{(v)}$, permanecendo no imaginário daquela década e se juntando a outras paradigmáticas obras do século XX, como Les demoiselles d'Avignon, de Pablo Picasso ${ }^{(v)}$, e o Quadrado ${ }^{(v)}$ preto sobre fundo branco, de Kazimir Malevich $^{(v)}$.

Para além do espanto provocado pela inesperada situação, os doze

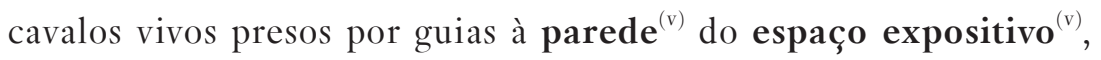
demarcando o perímetro $^{(v)}$ do lugar, eram um contundente gesto baseado na pesquisa que o artista vinha desenvolvendo ao menos desde 1967. Nas obras desse período, Kounellis associou materiais, objetos, fenômenos e formas de vida que denominou de sensibilidade ${ }^{(v)}$, como saco de juta ${ }^{(v)}, \operatorname{pedra}^{(v)}$, carvão $^{(v)}$, cabelo $^{(v)}$, $\operatorname{algodão}^{(v)}$, balança $^{(v)}$, gancho $^{(\mathrm{v})}$, ovo $^{(\mathrm{v})}$, prateleira $^{(\mathrm{v})}, \operatorname{trapo}^{(\mathrm{v})}$, fogo $^{(\mathrm{v})}$, papagaio $^{(\mathrm{v})}$, peixe $^{(\mathrm{v})} \mathrm{e}$ $\operatorname{plantas}^{(v)}$, a suportes de ferro ${ }^{(v)}$, definidos então como estrutura ${ }^{(v)}$.

Em Sem título (Papagaio), 1967, por exemplo, a apresentação ${ }^{(v)}$ da ave viva acontece em uma estrutura de ferro que possui as dimensões de uma folha de papel Fabriano(v) ${ }^{(v)} 100 \times 70 \mathrm{~cm}$. Com isso, o artista relaciona a vida, dada pela presença do animal, à cultura expressa pela folha para desenho. Essa combinação evocava a imagem da pintura Mulher com Papagaio, de Gustave Courbet $^{(\mathrm{v})}$, e a cultura do humanismo ${ }^{(\mathrm{v})}$ que se difundiu na Europa do século XV através do livro ${ }^{(v)}$ multiplicado pelas prensas de tipos móveis de Gutemberg abastecidas pela indústria papeleira de cidades como Fabriano, na Itália.

Em Sem título (Cavalo) a galeria era a estrutura, logo os doze cavalos, a sensibilidade. A dinâmica dialética entre os termos elaborados por Kounellis permitiram que ele formulasse outro conceito: a cavidade teatral $^{(v)}$. Ao pontuar tal conceito, o artista estabeleceu uma distinção entre a pintura $^{(v)}$ e seu antecessor histórico, o afresco ${ }^{(v)}$. Para ele, o afresco possuía uma relação física com a arquitetura, de suporte e imagética. Em outras palavras, se arquitetura encerrava o afresco dentro de um espaço, a imagem pintada abria a arquitetura, por meio de uma "janela". Aqui, encontramos um conjunto significativo de paralelos com a reflexão desenvolvida em 1972 por Hubert Damisch no livro Théorie 
$d u$ /nuage/, abordada nesta tese. Por ora, cabe apenas resumir que a conceitualização tecida por Kounellis articulava uma continuidade da pintura segundo uma lógica que entendia a pintura como a relação entre suporte e imagem, contexto e representação, estrutura e sensibilidade.

Portanto, tanto o papagaio com a chapa de ferro, de 1967, quanto os doze cavalos na galeria, de 1969, eram pinturas para o artista, pois apresentavam um desenvolvimento histórico da relação anteriormente citada e da linguagem $^{(v)}$ da pintura, contrapondo radicalmente o discurso da crítica de que Kounellis trabalhava para o fim da pintura, algo que o artista negou durante toda sua carreira ao se denominar repetidas vezes um pintor $^{(v)}$.

A definição de pintura de Kounellis, que o levou à criação das obras da segunda metade da década de 1960, foi formulada em duas séries de pinturas anteriores, realizadas em meios e suportes tradicionais, tinta sobre tela. Na primeira, feita entre 1958 e 1964, o artista produziu uma partitura $^{(v)}$ composta por números $^{(v)}$, letras e outros signos gráficos que correspondiam a uma espécie de alfabeto recitado pelo artista no decorrer das sessões de pintura. Por raramente articular uma palavra ${ }^{(v)}$ ou texto inteligível, essa linguagem do fragmento ${ }^{(v)}$ se aproximava das poesias fonéticas de Hugo Ball ${ }^{(v)}$ e Kurt Schwitters ${ }^{(v) 1}$. Na segunda série, produzida entre 1964 e 1967, Kounellis realizou sobre a tela jogos de linguagem nos quais a cor era usada para alterar a percepção e a ordem de representação das palavras e silhuetas - em forma de flor pintadas $^{2}$.

Ao observar os desenvolvimentos internos da poética de Kounellis entre 1958 e 1969 , percebermos que para ele a linguagem artística era a indissociável junção entre técnica e teoria, entre o fazer e a conceitualização. Contudo, essa convergência não era inédita, já que, por exemplo, a escolha técnica de Masaccio ${ }^{(v)}$ por um tipo de escorço que reproduzia com mais exatidão do que seus antecessores o peso ${ }^{(v)}$ das figuras, no plano teórico, sinalizava a compreensão delas não apenas em termos de superfície, mas também de massa.

1 Ver exposição Kounellis. Roma: Galleria La Tartaruga, 1960.

2 Ver exposições Jannis Kounellis. /l giardino/ I givochi e I giuochi di Jannis Kounellis. Roma: Galleria I'Attico, 1967.
Para Kounellis, o conhecimento da linguagem da arte era o saber do $\operatorname{artista~}^{(v)}$, que também era o seu guardião ${ }^{(v)}$. Logo, quando ele citava Giovanni Piranesi $^{(v)}$, Caravaggio ${ }^{(v)}$, Georges La Tour ${ }^{(v)}$, Francisco Goya $^{(v)}$, Jacques-Louis David ${ }^{(v)}$, Eugène Delacroix ${ }^{(v)}$, Edvard Munch ${ }^{(v)}$, Vincent van Gogh $^{(v)}$, Alberto Giacometti ${ }^{(v)}$, Jackson Pollock ${ }^{(v)}$, Henry 
Moore $^{(v)}$, Alberto Burri ${ }^{(v)}$, Lucio Fontana ${ }^{(v)}$ e outros artistas era, na maioria das vezes, para estabelecer relações em termos de linguagem a fim de frisar os laços entre a sua poética e o campo da arte.

Voltando ao conceito de estrutura, é importante mencionar que, além das dimensões do papel Fabriano e do espaço expositivo, ainda na década de 1960 , Kounellis elegeu também a medida da cama ${ }^{(v)}$ de solteiro, $200 \times 90 \mathrm{~cm}$, como modo de evocar em suas peças a escala ${ }^{(v)}$ humana e consequentemente a cultura. Nos anos seguintes, ele aplicou essas medidas a chapas de ferro e, através da junção de vários desses painéis, chegou a novas dimensões.

Outra obra representativa do artista produzida nos anos de 1960, e posteriormente desdobrada em novos trabalhos, foi Sem título, 1969, na qual um conjunto de balanças continha porções de café ${ }^{(v)}$ em pó. O forte odor $^{(v)}$ do café promovia, pelo olfato, uma antecipação ${ }^{(v)}$ da experiência sensorial do olhar no espaço expositivo.

Kounellis continuou a desenvolver na década seguinte obras nas quais outros sentidos eram privilegiados em detrimento da visão, em especial com o uso da música ${ }^{(v)}$. A performance ${ }^{(v)}$ de músicos profissionais executando fragmentos de peças clássicas, em diferentes trabalhos, além de inserir no léxico de objetos de Kounellis os instrumentos musicais ${ }^{(v)}$, gerava reverberações acústicas pelo espaço expositivo, fazendo com que a experiência sonora antecipasse a visual. Em uma parcela dessas performances, Kounellis permanecia em cena trajando uma máscara ${ }^{(v)}$ de gesso que representava Apolo, deus associado às artes e à música. $\mathrm{O}$ preenchimento sonoro do espaço me parece ser "traduzido" visualmente em Sem título, 1976, obra na qual um forno com chaminé(v) foi instalado e ligado no interior da galeria Salvatore Ala, em Milão. A fumaça ${ }^{(v)}$ gerada pela queima de madeira criava uma grande mancha ${ }^{(v)}$ de fuligem nas paredes do espaço.

Outro conjunto de obras realizado pelo artista nesse período articulava a ideia de viagem ${ }^{(v)}$. Nessas peças, velas de barco $^{(v)}$ e modelos de embarcações $^{(v)}$ evocavam rotas marítimas; para caminhos por terra, uma locomotiva $^{(v)}$ em miniatura era associada, em geral, a uma coluna ${ }^{(v)}$. Peças de vestuário ${ }^{(v)}$, como sapatos, casacos e chapéus associados ao ouro ${ }^{(v)}$ também auxiliavam na criação da imagem de deslocamento, só que nesse caso, espiritual e histórico, correspondendo ao uso do material por artistas como Andrei Rublev ${ }^{(v)}$ e Gustav Klimt ${ }^{(v)}$. 
Contudo, um terceiro grupo de trabalhos, produzidos por Kounellis por meio da obstrução com diversos materiais de uma porta ${ }^{(v)}$ ou janela $^{(v)}$ do espaço expositivo, à primeira vista parece contradizer as ideias de reverberação e mobilidade presentes nas obras produzidas em simultâneo. No entanto, segundo o artista, a intenção dessas peças não era o fechamento, mas a revelação da escala humana na arquitetura. Logo, a presença do humano se mostrava como um contexto para os materiais usados nos trabalhos. O jogo entre oclusão e revelação também foi explorado por Kounellis na elaboração de máscaras baseadas no bloqueio de sua boca ${ }^{(v)}$ por um material ou objeto, para indicar aspectos de uma língua que fala por meio das coisas.

Nos anos de 1980 e 1990, há uma significativa ampliação das dimensões das obras de Kounellis, o que põe em evidência o procedimento de acumulação ${ }^{(\mathrm{v})}$. Além disso, no decorrer de inúmeras exposições individuais, são incorporados novos elementos ao repertório do artista, dentre os quais se destacam: faca ${ }^{(v)}$, $\operatorname{cortina}^{(v)}$, carne $^{(v)}$, $\operatorname{armário}^{(v)}$, mesa $^{(v)}$, máquina de costura ${ }^{(v)}, \operatorname{sino}^{(v)}, \operatorname{grapa}^{(v)}, \operatorname{cadeira}^{(v)}$ e flores $^{(\mathrm{v})}$. Já o procedimento de acumulação é nitidamente percebido quando Kounellis passa a remontar obras concebidas em função das dimensões do espaço expositivo. Ao invés de adaptar o espaço para receber essas peças na nova situação de montagem, o artista opta por preservar a escala original dos trabalhos, mas os dispõem no espaço de modo que fique evidente o descompasso entre a escala do lugar e a escala da obra. Assim, cada exposição corresponde a uma etapa de migração $^{(v)}$ realizada pelas obras, que saem de seus locais de origem, mas carregam em sua escala e materiais aspectos essenciais daquele lugar.

Sobre o léxico de objetos usados por Kounellis, creio que, além da direta associação com a poética do ready-made duchampiano, as escolhas do artista se aproximam da rigorosa seleção de objetos feita por Paul Cézanne ${ }^{(v)}$, que a um só tempo se referia a aspectos do contexto da vida em Aix-en-Provance e à história da arte. Já a repetição do objeto para a construção da obra, tendo em vista a ideia de acumulação, se aproxima da lógica da litania ${ }^{(v)}$ na qual cada repetição insere também uma nova variação.

Kounellis também desenvolveu nessa época o conceito de catedral ${ }^{(\mathrm{v})}$ por meio das ideias de centralidade ${ }^{(v)}$ e verticalidade ${ }^{(v)}$, inclusive, no decorrer de sua atividade como professor $^{(v)}$, entre 1993 e 2001, na Academia de Artes de Düsseldorf, herdando a cátedra anteriormente 
ocupada por Joseph Beuys. Além disso, esse arco temporal de vinte anos concentra uma parcela significativa da produção de Kounellis na área de cenografia para teatro ${ }^{(v)}$, atividade que o artista manteve ao logo de toda a sua carreira. Foi também nos anos 1980 e 1990 que se intensificou a produção textual de Kounellis, sendo essa uma franca declaração ${ }^{(v)}$ do artista sobre suas referências, interesses e posições em relação ao sistema da arte.

Nos textos de Kounellis, não há uma preocupação com a diagramação, mas com a narrativa e se nota, no decorrer da produção escrita, uma experimentação de vozes narrativas, tons e distâncias entre narrador e leitor.

Na segunda parte deste trabalho há uma seção com textos do artista, em grande parte extraídos e traduzidos das coletâneas Odysée lagunaire: écrits et entretiens 1966-1989 (1990), Fannis Kounellis: works, writings 19582000 (2001) e Echoes in the darkness: writings and interviews 1966-2002 (2002). No Brasil, até então apenas um texto de Kounellis havia sido traduzido para o português e publicado em Escritos de Artista: anos 60/70 $(2006)^{3}$, coletânea organizada por Glória Ferreira e Cecília Cotrim.

Entre 2000 e 2016, Kounellis desenvolveu dois modos de organização de suas obras no espaço, o labirinto ${ }^{(v)}$ e a caravana $^{(v)}$, e começou a realizar peças em forma de esquife ${ }^{(v)}$. Para o labirinto, o artista utilizava dezenas de estruturas de ferro com o topo vazado e, em geral, preenchido com carvão. Após dispor essas peças no espaço expositivo desenhando um labirinto, Kounellis fixava no interior deste um conjunto de obras. Já no formato de caravana, ele dispunha suas peças no espaço de modo que essas determinassem uma linha atravessando-o. Nesse período, Kounellis também retomou certas formas utilizadas anteriormente ao longo de sua carreira, porém as materializou com outros elementos. Ao observar essas obras e exposições, tendo em vista seus "originais" de décadas anteriores, percebe-se a produção de uma sensação de encerramento, de término, dada pela aspereza, sobriedade e síntese formal desses trabalhos. 

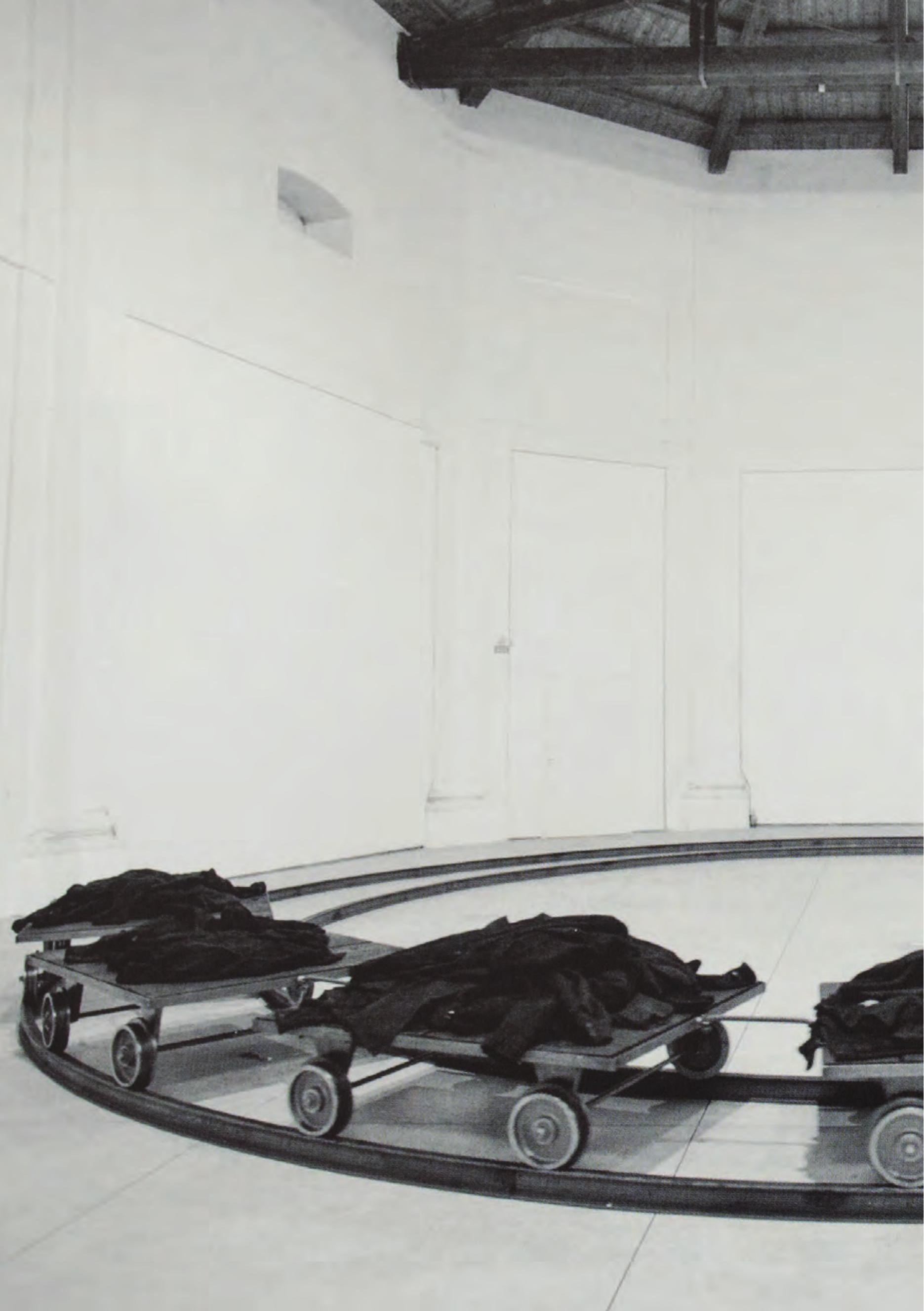


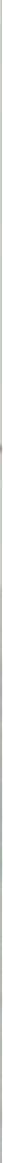




\section{Acumulação}

Perto do Panteão (em Roma) há uma escultura de Bernini que representa um pequeno elefante carregando em suas costas um pequeno obelisco egípcio. Bernini combinou o obelisco - forma muito antiga - com um elefante que ele retirou de um desenho de Rafael. Isso é um exemplo de acumulação. Em seus trabalhos dos últimos quinze anos, os artistas americanos fizeram sua escolha por eliminar a ideia de acumulação. Eles escolheram outro tipo de lógica. O quadrado elimina a possibilidade de acumulação ${ }^{1}$.

A ideia de acumulação é um conceito fundamental para a compreensão da produção artística de Kounellis e para o entendimento do artista sobre arte e produção artística. A acumulação, segundo Kounellis, é um procedimento inerente ao fazer artístico europeu. Para ele, o artista europeu olha para a história e busca a partir da retomada do passado estabelecer um diálogo constante com o presente para, assim, avançar. Essa lógica é diferente da utilizada pelos artistas americanos que, nas palavras de Kounellis, "descobrem o fio dourado e depois o abandonam. Mudança. O tipo de história nômade. $\mathrm{O}$ medo de que o fio estivesse esgotado. Portanto não pode haver progresso. Enquanto somos exatamente o oposto. Temos revolução, um retorno ao passado" Posteriormente, em "Omelia", de 1985, ao citar Donald Judd, Kounellis explicitou que se referia à produção minimalista quando enunciava a lógica americana. Logo, segundo o ponto de vista do artista, podemos supor que existem, ao menos, dois modos de produção artística que resultam de construções distintas da história de arte.

No exemplo da escultura de Bernini, vemos um trabalho que é o resultado da junção de dois objetos. A interpretação tridimensional do desenho de Rafael carrega um obelisco, objeto egípcio e forma que Bernini já havia utilizado em obras anteriores como a Fonte dos quatro rios, localizada na Praça Navona. Para Stephen Bann, Bernini estava acostumado a incorporar objetos preexistentes, baseado na complexa noção de influência. Esse procedimento serviu para construir uma narrativa histórica: "É a criação estratégica de novas entidades compostas que representam a estratificação e, portanto, a intensificação mútua de diferentes estratos históricos" ${ }^{3}$. Em outras palavras, o presente se assenta sobre o passado. Para o artista que utiliza a lógica da acumulação sempre há um ponto de partida já solidificado. Conforme Kounellis apontou em conversa com Joseph Beuys, Enzo Cucchi e Anselm Kiefer:
1 Sem título, 2016. Cavalo, condutor, trilho e cinco carrinhos com casacos. Exposição fannis Kounellis, Centro de Artes Visuais Pescheria, Pésaro, 2016.

Foto: Michele Alberto Sereni. [Página dupla]

2 Sem título, 1977.

Miniatura de trem elétrico

sobre círculo de ferro fixado a uma coluna. Claustro de Santa Maria Novella, Florença, 1977. Foto: Paolo Pellion di Persano.

1 (KOUNELLIS, 1990 p. 79, tradução nossa). Salvo indicação em contrário, todas as traduções utilizadas neste trabalho são nossas. 
Um monumento como a Catedral de Colônia indica uma centralização, abrange uma cultura e indica o caminho para um desenvolvimento vindouro. Sem esses sinais, correríamos o risco de nos tornar nômades ${ }^{4}$.

Antes de apontar como Kounellis trabalhou a partir da ideia de acumulação, cabe salientar que as peças do artista não são monumentos ${ }^{5}$, como é a escultura de Bernini, ou seja, não foram pensados para se fixarem permanentemente em determinado lugar ${ }^{6}$, apesar de quase sempre se relacionarem ao contexto no qual são apresentadas.

A produção de Kounellis localizada entre os anos de 1967 e 1979 demonstra refinado senso e capacidade de evocação de imagens procedentes da história da arte e de seu repertório artístico. Nesse período, Kounellis desenvolveu o que chamava de "estrutura(v) e sensibilidade $^{(v)}$ ". Na produção anterior, de 1959 a 1966, Kounellis se dedicou a pinturas realizadas com tinta de parede sobre lonas esticadas diretamente nas paredes de seu ateliê. Nas sessões de pintura Kounellis vestia uma de suas telas e, à medida que ia pintando letras, números $^{(v)}$ e símbolos que se assemelhavam a pichações, recitavaos em voz alta. O inusitado traje e a ação de recitar eram uma clara referência à performance de Hugo Ball ${ }^{(\mathrm{v})}$ realizada em 1916 no Cabaré Voltaire. Além disso, as pinturas, ao serem apresentadas em exposições, guardavam em si a escala do lugar de trabalho; logo, ao serem exibidas, essas pinturas acumulavam o deslocamento de signos do espaço público para o privado e a transposição de escalas do ateliê para a galeria. Por fim, nos trabalhos feitos entre 1980 e 2016, sem abdicar de procedimentos anteriores, Kounellis expande seu repertório de três formas. Primeiramente, Kounellis começa a usar o espaço expositivo ${ }^{(v)}$ como "molde". Os trabalhos são construídos no lugar de exibição e incorporando sua escala. Ao reapresentar essas peças em exposições posteriores, Kounellis mantém as dimensões originais do trabalho isso é visível quando o artista usa vigas de metal para criar um frame que contém e é a obra (ver e comparar imagens na sequência 23, 24, $25,180,105,124)$. Esse procedimento recupera a ideia de transposição de escala das pinturas iniciais. Os trabalhos resultantes carregam, em suas dimensões, a "memória" de um espaço. Além disso, os materiais que compõem essas obras aludem ao histórico de uso e ao contexto no qual se localiza o espaço usado como gabarito. Em paralelo, Kounellis adapta trabalhos anteriores a 1979 a novas situações de montagem, modificando certos elementos, mas preservando sua imagem ${ }^{(v)}$ (ver e comparar imagens na sequência 49,141, 17, 59). E, por fim, mas não menos importante, Kounellis junta trabalhos já existentes para elaborar
4 (BEUYS; CUCCHI; KIEFER; KOUNELLIS, 1986).

5 Neste trabalho utilizo a noção de monumento usada como ponto de partida por Rosalind Krauss em seu ensaio "Sculpture in the expanded field", publicado em 1979 na revista October, no volume oito.

6 Kounellis realizou poucas obras destinadas à permanência em espaço público, entre essas destaco: Sem título, de 1992, instalada originalmente instalada na esquina das ruas Baluard e Almirall Cervera, em Barceloneta, e atualmente instalada na área externa do Centro Cívico, na esquina das ruas Miquel Boera e Andrea Dòria, Barcelona, Espanha; Sem título (Resistência e Libertação), de 1994, instalada na Universidade de Pádua; Sem título, 1995, instalada na Praça do Plebiscito em Nápoles; e Sem título, 2001, instalada na estação Dante do metrô de Nápoles (ver imagens 93, 187, 56 e 88, respectivamente). 

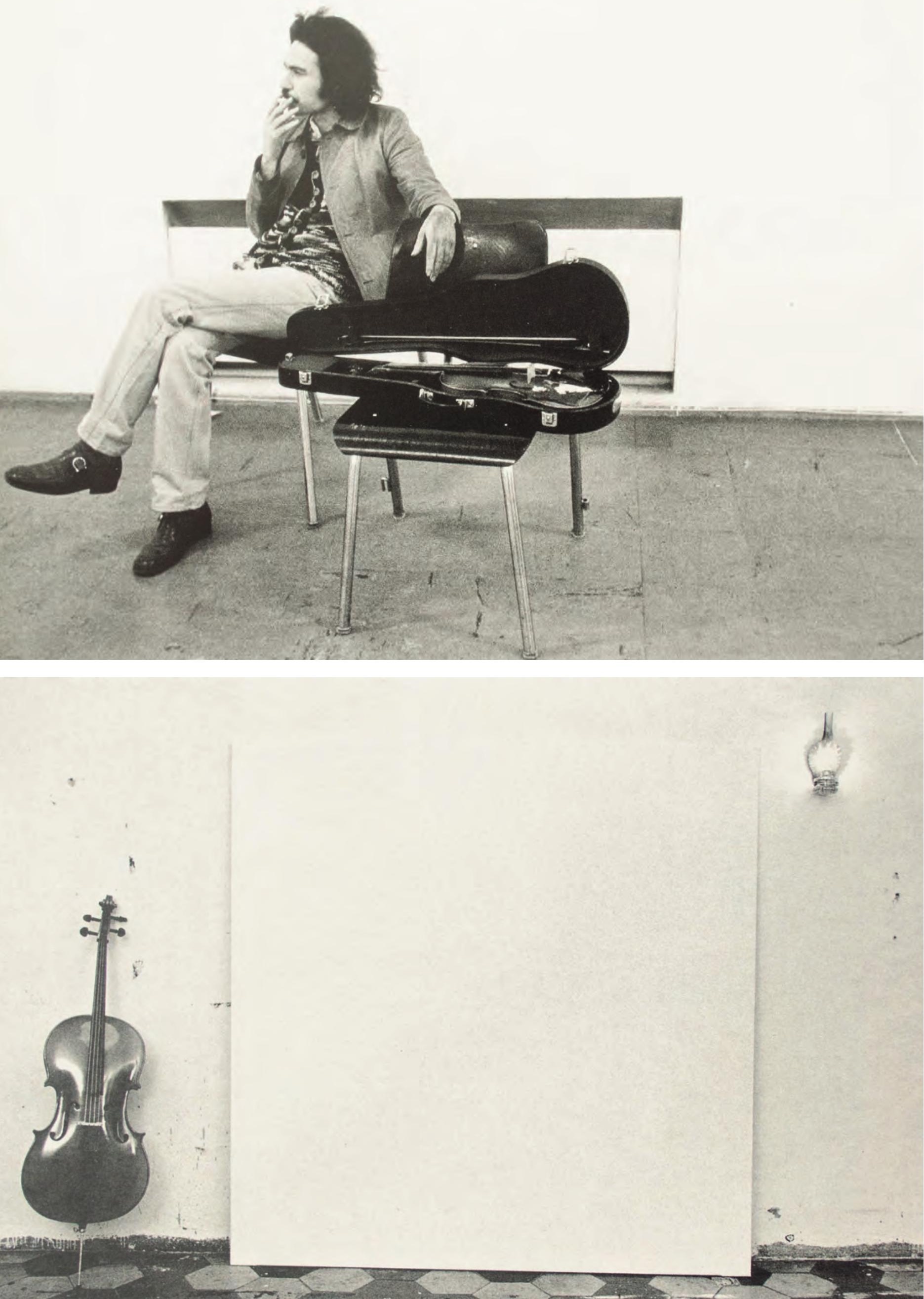
novas peças (ver e comparar imagens na sequência 58, 161, 62, 143, 70, 69, 71, 167, 72, 73). Em suma, nos últimos 36 anos de carreira, Kounellis desenvolveu a acumulação como uma experiência interna de sua poética.

\section{Afresco}

Kounellis, em diferentes ocasiões, distinguiu afresco de pintura $^{(v)}$, pois, para ele, cada um desses termos opera uma lógica técnica distinta.

Naqueles primeiros anos, os afrescos ofereciam um suporte para a pintura, amarrando-a à arquitetura e ao público. [...] mas o afresco implica não apenas a aplicação de tinta na parede... é uma questão de dimensões físicas e suporte arquitetônico, a formação de uma imagem dentro dos limites oferecidos pela arquitetura e por aquilo que o pintor tem à mão, por acaso. [...] Estava conectado a um espaço público, a um teatro, à igreja com seu poder e ideologia?.

Ao colocar em questão a natureza do afresco - recordando que tecnicamente o afresco é a aplicação de pigmento e aglutinante no reboco de gesso ainda fresco -, Kounellis sinalizava primeiramente a relação existente entre técnica e suporte que se desdobra também na relação entre obra e contexto. A técnica do afresco possui limitações físicas de mobilidade impostas por seu suporte, no caso pela arquitetura, ou seja, o afresco é uma obra fixa. Porém, se o afresco está encerrado e fixado no interior da arquitetura, a imagem produzida dialogará com o espaço físico de modo a produzir janelas que prolongam imageticamente o espaço. Em outras palavras, a técnica do afresco está intimamente ligada à teoria pictórica da perspectiva e, consequentemente, da janela renascentista. A inovação técnica da pintura a óleo sobre madeira e, logo em seguida, sobre a tela esticada em chassi de madeira formulou, posteriormente, um novo problema dado pela perda do contexto, pois, com a mobilidade do suporte, a imagem pictórica não estava mais confinada a um único espaço. Os artistas modernos, grosso modo, compreenderam essa ruptura técnica entre a imagem pictórica e o espaço arquitetônico por meio do estabelecimento de uma nova teorização da arte cujo problema central seria a relação entre arte e vida. Contudo, a produção artística não se dissolveu no fluxo da vida, apesar de algumas experiências artísticas conseguirem suspender temporariamente a fronteira entre elas. O cubo branco como espaço expositivo(v) $^{(v)}$ tornou-se o lugar de "estadia" da produção moderna e
4 Homenagem à Louis

Morris, 1971. Kounellis

com a mão esquerda suja de

tinta azul, verde, amarela,

roxa e vermelha, cadeiras,

violino, estojo de violino

e partitura da Sinfonia $n^{\circ} 9$

de Antonín Dvořák. Foto:

Claudio Abate.

5 Sem título, 1974.

Violoncelo, tela e

lamparina. Foto: Claudio

Abate.
7 (KOUNELLIS; CODOGNATO; D'ARGENZIO, 2002, p. 289-291). 


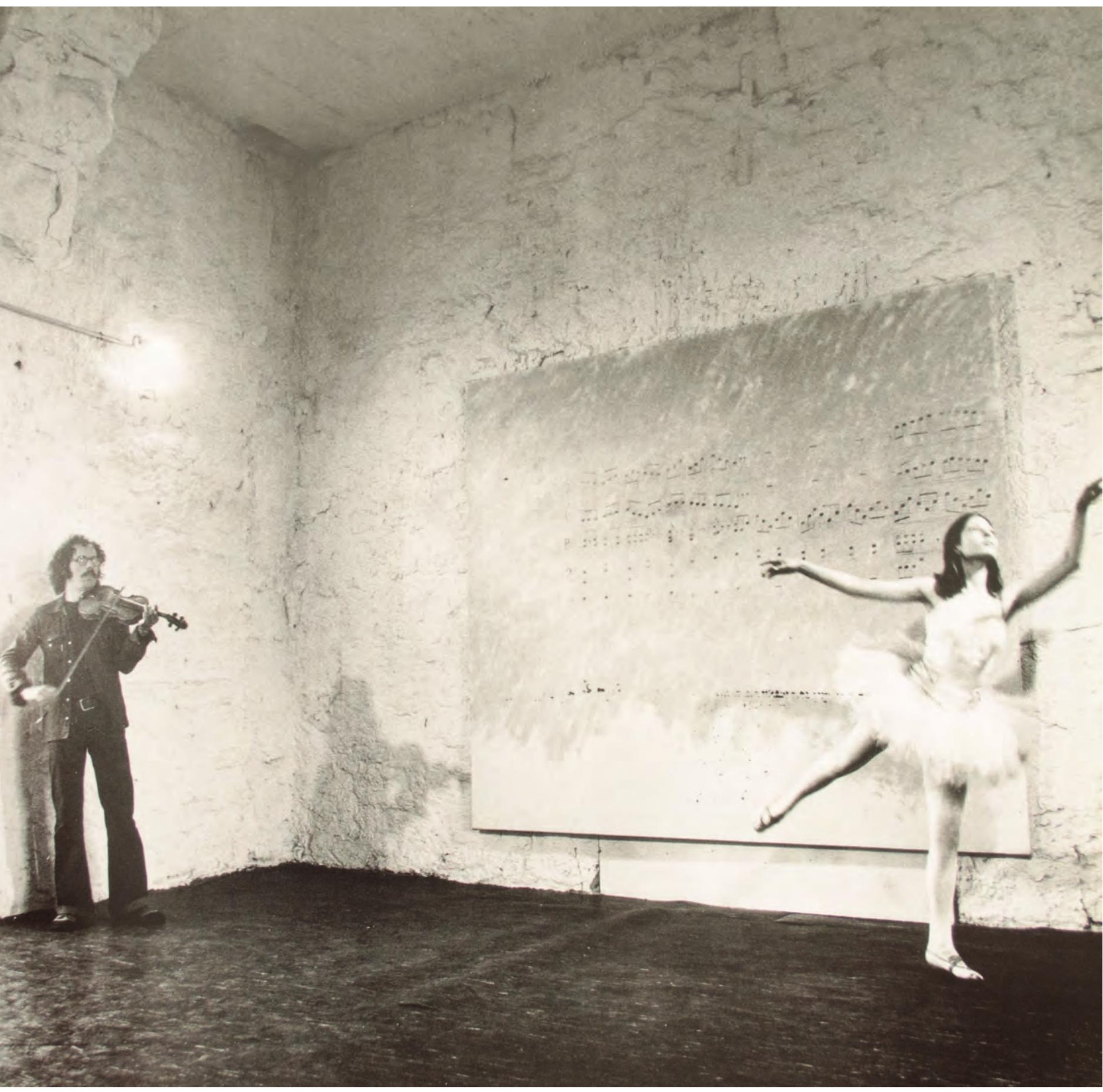


contemporânea, oferecendo-lhe inicialmente um contexto vinculado ao campo da arte. A partir dessa discussão sobre a técnica do afresco, Kounellis desenvolveu o conceito de cavidade teatral ${ }^{(v)}$.
6 Sem título (a ser inventado no local), 1972. Óleo sobre tela, bailarina e violinista executando fragmento da Tarantela de Stravinsky. Foto: Claudio Abate.

\section{Algodão}

O algodão é um material orgânico que evoca setores da atividade produtiva e de consumo, como a agricultura, a indústria e o comércio. $\mathrm{O}$ algodão, em seu estado bruto, é um aglomerado de fibras entrelaçadas cuja forma é definida por seu continente. Em 1967, Kounellis associou esse material à ideia de sensibilidade $^{(v)}$ para produzir Sem título, uma estrutura ${ }^{(v)}$ de ferro ${ }^{(v)}$ que contém um volume de algodão (ver imagem 22).

\section{Antecipação}

Dentro do léxico de material de Kounellis, encontramos matérias intangíveis como o som e o odor ${ }^{(\mathrm{v})}$. Por se relacionarem a outro modo de apreensão do sensível que não o visual, essas matérias sonoras ou olfativas antecipam, no espaço expositivo ${ }^{(v)}$, determinadas experiências físicas do observador com a obra em detrimento da visão. Em geral, essas matérias intangíveis se relacionam ao conceito de sensibilidade ${ }^{(v)}$.

\section{Apresentação}

Desde os anos 1960, inúmeros termos foram usados pela crítica de arte para designar a produção artística de Kounellis e, assim, apontar suas filiações. Kounellis, ao longo de sua carreira, se definiu como um pintor $^{(v)}$ cuja poética se constituiu por meio da linguagem ${ }^{(v)}$ plástica da apresentação. Ou seja, ao invés de representar objetos, o artista os apresenta segundo uma determinada lógica de concisão. Embora o debate sobre a representação e a apresentação dentro do campo das artes visuais seja comumente associado ao período histórico da Arte Moderna, é importante salientar que a preocupação dos artistas anteriores à modernidade em criar sistemas técnicos e teóricos capazes de representar o mundo visível fundou e construiu a linguagem da pintura e da escultura. Por conseguinte, esses sistemas de representação se estabeleceram como modos de apresentação do visível segundo determinados parâmetros, tornando, inclusive, a apresentação do objeto um procedimento válido dentro do campo da arte. 

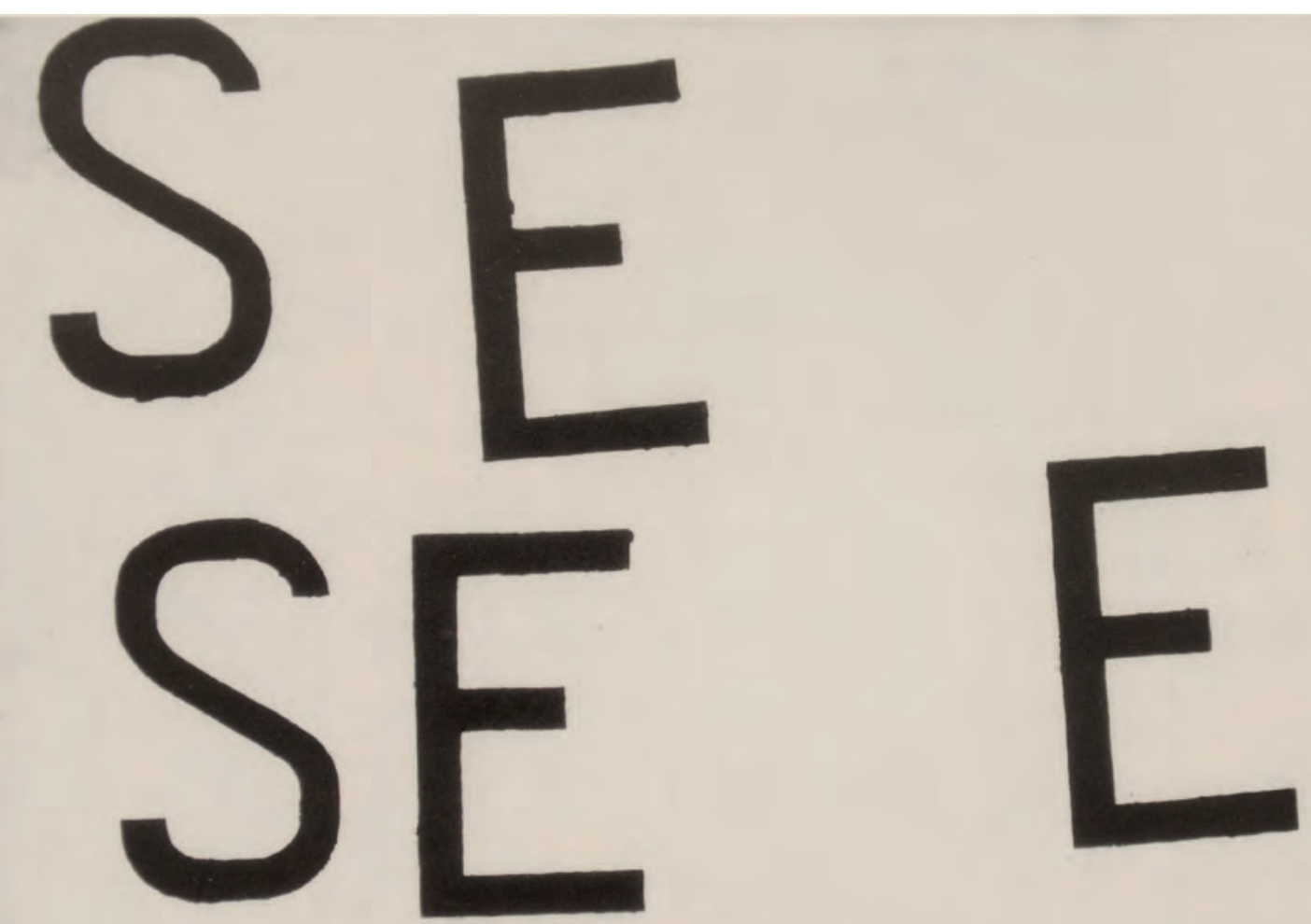

SI LTF PS EUTIII. II I)

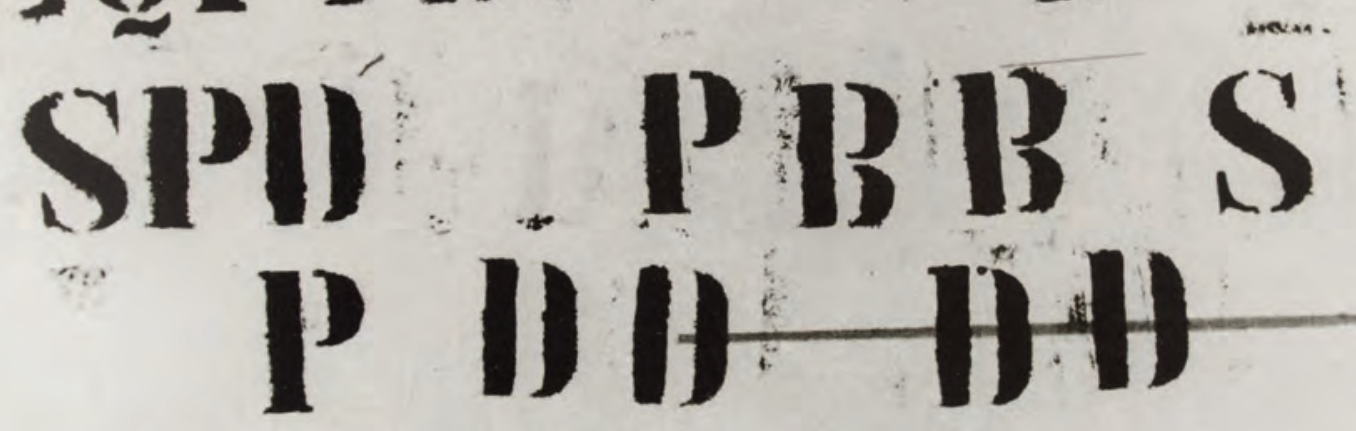




\section{Armário}

O armário é uma peça de mobiliário que possui a ideia de armazenamento, no entanto, raramente foi preenchido na obra de Kounellis com outros materiais ou objetos. O armário foi, em geral, apresentado em conjunto de quatro ou mais e em duas configurações distintas. Na primeira, em linha ou fila, é sugerida a imagem ${ }^{(v)}$ de cortejo ou caravana $^{(v)}$. Na segunda configuração, em agrupamentos regulares, parece indicar uma conversa em grupo. Em ambos os casos há a sugestão de antropomorfismo (ver imagens 12, 35).

\section{Arte Povera}

Nomenclatura cunhada pelo crítico italiano Germano Celant, em 1967, para designar inicialmente uma parcela da produção artística italiana dos anos 1960 que utilizava materiais pouco familiares ao campo da arte. Posteriormente, em 1969, Celant usou o conceito para abarcar também parte da produção europeia e americana contemporânea da italiana ${ }^{8}$. Para Michelangelo Pistoletto, artista cuja produção foi identificada por esse conceito, a Arte Povera foi o último movimento moderno, por conta da radicalidade de suas proposições artísticas. Em palestras realizadas no Brasil em 2018, Pistoletto também afirmou que para os artistas italianos identificados com a Povera havia a preocupação de diálogo com a história da arte: "em italiano, a palavra radical tem origem na palavra raiz, ou seja, há um direcionamento. Há algo de pertencer e fazer arte a partir de uma raiz, de uma história" . A afirmação de Pistoletto sobre a ligação entre radicalidade e história encontra paralelos nos conceitos de acumulação ${ }^{(v)}$, cavidade teatral $^{(v)}$ e linguagem $^{(v)}$ formulados por Kounellis.

\section{Artista}

"Eu sou uma pessoa grega, mas um artista italiano"10. Apesar de Kounellis contrapor em alguns momentos o termo artista a pintor ${ }^{(v)}$, creio que não há contradição nessa declaração, uma vez que ela está relacionada à sua formação como artista, o que, indiretamente, evoca a tradição da arte italiana, apontado para o lastro histórico ao qual ele escolheu se filiar. Para Kounellis, o artista era o guardião ${ }^{(v)}$ da linguagem $^{(v)}$ da arte, ele a domina e a transmite seja por meio de suas obras seja pela atividade como professor $^{(\mathrm{v})}$.
7 Sem título, 1959. Esmalte sobre tela. $138 \times 245 \mathrm{~cm}$. Foto: Claudio Abate. 8 Sem título, 1959. Nanquim sobre papel. $47 \times 66 \mathrm{~cm}$. Foto: Claudio Abate. 


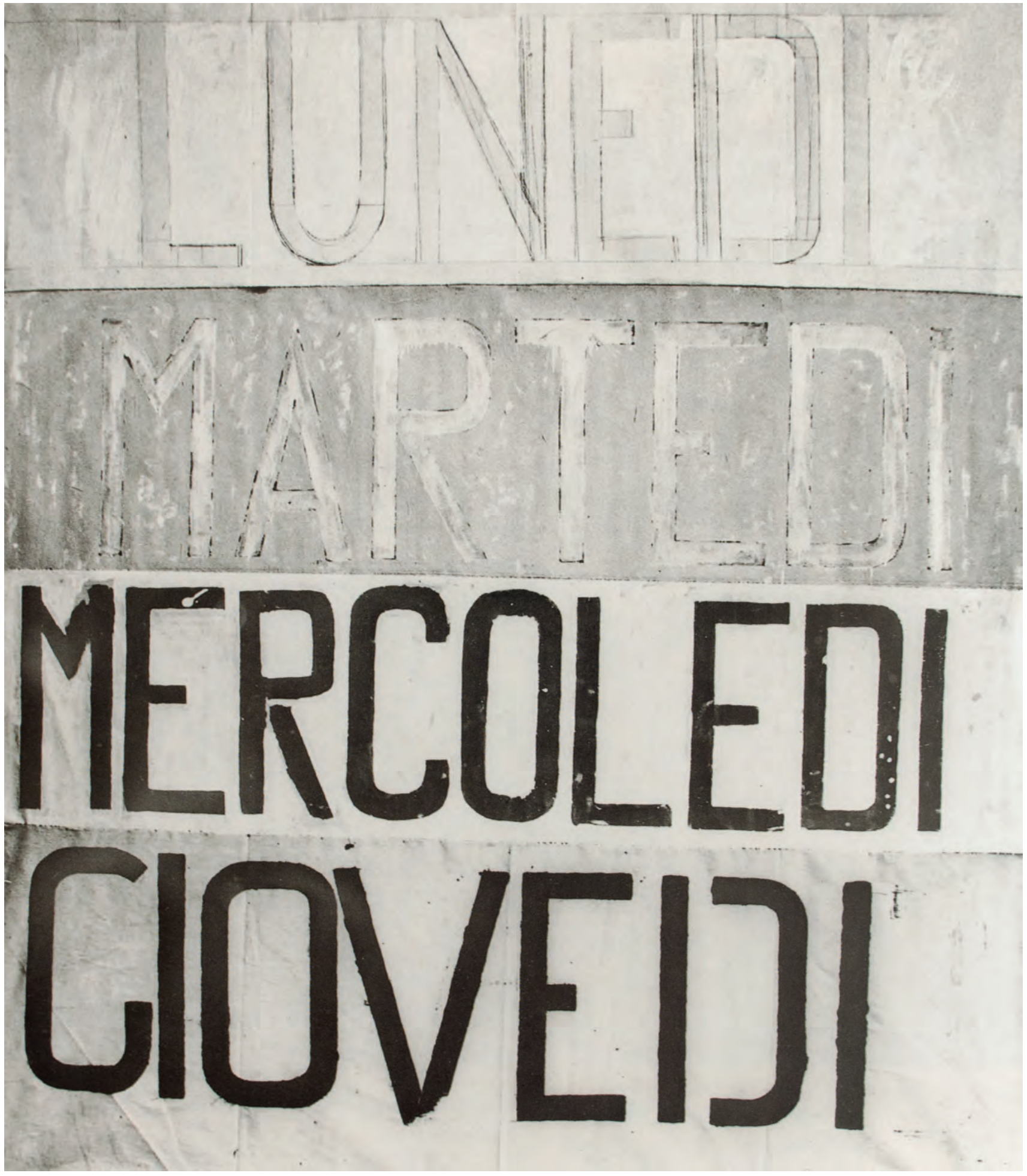


Outro dado que essa declaração parcialmente revela foi a escolha de Kounellis em mudar-se, ainda jovem, aos 20 anos, do Pireu para a cidade de Roma, onde estudou, trabalhou e residiu. Simbolicamente, o artista migra entre centros históricos da cultura ocidental, da Grécia para a Itália.

\section{Balança}

A forma balança foi, na produção de Kounellis, uma das manifestações do conceito de estrutura ${ }^{(v)}$. Inserida no ano 1969, em trabalhos para ambientes internos, inicialmente continha elementos como café ${ }^{(v)}$ e fogo $^{(v)}$ (ver imagens 156, 163). Posteriormente, as balanças passam a conter também outros materiais, como: porcelanas, taças, copos e jarras de vidro e de vidros coloridos de murano. A balança, por sua imagem $^{(v)}$, sugere as ideias de comércio e peso ${ }^{(v)}$, sendo que a ideia de peso se refere tanto à prática da mensuração quanto ao sistema de representação pictórico. Porém, é importante salientar que as balanças de Kounellis não atuam como instrumentos de medição, pois não há contrapeso para ajuste e aferição do peso dos objetos. Por sua vez, os objetos escolhidos por Kounellis, por suas propriedades materiais como odor $^{(v)}$ (café), transparência (vidro) e duração (chama do combustível sólido), parecem ser dotados de extrema leveza. Essa relação entre conteúdo e continente, marcada pela sugestão de pesar aquilo cujo peso é ínfimo, reitera a incapacidade da balança atuar como instrumento de medição, revelando aspectos da natureza de objetos e materiais que devem ser mensurados pelo observador através de outros critérios. Em obras externas, a balança foi usada pela primeira vez em Barcelona, em 1992, e continha sacos de café. Sobre esse trabalho, Kounellis publicou "Onde quer que eu tenha deixado minha capa de chuva", onde estabeleceu as relações de escala entre as balanças feitas para espaços internos e a balança apresentada numa pequena praça de Barceloneta, em Barcelona (ver imagem 93).

\section{Ball, Hugo (1886-1927)}

Poeta alemão, Ball foi um dos primeiros poetas a desenvolver a poesia fonética, que sobrepõe a qualidade sonora presente nas letras, sílabas e palavras aos valores semânticos e sintáticos. Uma parte significativa dos poemas de Ball foi apresentada pelo próprio em recitais realizados no Cabaré Voltaire, em Zurique, durante a década de 1910. Na 

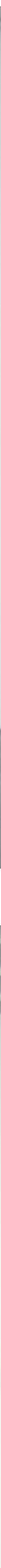
performance $^{(v)}$ de 1958 em seu ateliê, Kounellis vestido com uma de suas pinturas realizava uma sessão de pintura $^{(v)}$ na qual cada letra, número e signo gráfico pintado sobre a tela era posteriormente recitado pelo artista, que afirmava que essas pinturas indicavam uma partitura ${ }^{(v)}$. Nessa performance, Kounellis, assim como Ball, estava interessado nos aspectos sonoros da palavra ${ }^{(v)}$. Além disso, pela semelhança visual entre a vestimenta de Kounellis e a roupa usada por Ball em seus recitais, temos a confirmação de que o artista buscava evocar o poeta (ver imagem 169) [ver números $\left.{ }^{(\mathrm{v})}\right]$.

\section{Boca}

Na década de 1970, Kounellis realizou um grande conjunto de performances. Desse conjunto, destacam-se duas peças em que a boca do artista era um dos elementos centrais. Em 1972, para a exposição Roma - Mappa $72^{11}$, Kounellis apresentou uma performance ${ }^{(v)}$ na qual um pianista e uma cantora lírica repetiam uma parte da ópera Carmen, de Georges Bizet, enquanto ele permanecia sentado à mesa calado e com seus lábios selados por folhas de ouro(v) (ver imagens 92, 74). Já em 1973, na Galeria Lucio Amelio, em Nápoles, Kounellis apresentou uma performance em que segurava, com a boca, um maçarico aceso (ver imagem 109). Na década de 1980, Kounellis não realizou performances, mas nos anos 1988, 1989 e 1990 voltou a usar a própria boca como elemento compositivo em fotografias utilizadas, em geral, na confecção de peças gráficas destinadas à divulgação de exposições. As imagens frontais e de perfil apresentavam uma miniatura de trem (1988), uma vela acesa sobre uma pequena chapa de metal (1989) e um pedaço de carvão (1990) "fechando" a boca do artista (ver imagens 3, 185 e 149 respectivamente). Segundo Philip Larratt-Smith, "para Kounellis, a cavidade da boca é um portal entre o interior e o exterior, um espaço transicional que é metaforicamente equivalente a uma porta: 'em vez de bloquear uma abertura arquitetônica, eu bloqueio uma abertura orgânica"'12. Contudo, como o próprio Kounellis afirma em "As palavras que me explicam", a oclusão da cavidade de uma porta permitiu a ele construir uma imagem ${ }^{(v)}$ com pedras que revela o tamanho de uma porta $^{(v)}$ e, consequentemente, a escala humana da arquitetura. Nesse sentido, a obstrução da boca do artista constrói a imagem de uma linguagem $^{(v)}$ que confere aos objetos e materiais um valor equivalente ao verbal. Em outras palavras, esses trabalhos revelam que o artista fala através de determinados objetos [ver pedra $\left.{ }^{(v)}\right]$.
10 Sem título, 1988. Ferro, sacos de juta e lamparina. $420 \times 1290 \times 50 \mathrm{~cm}$. Foto: Claudio Abate.

11 Sem título, 1988. Ferro e sacos de juta. Foto: Claudio Abate.
11 Roma - Mappa 72, Encontro Internacional de Arte, Palazzo Taverna, Roma, Itália, de 20 de novembro a 18 de dezembro de 1972. Kounellis realizou essa performance no dia 11 de dezembro de 1972. 12 (KOUNELLIS; LARRATTSMITH; FUCHS, 2019, p. 72). 


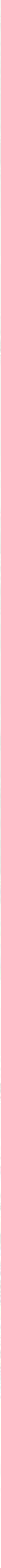


Artista italiano, Burri foi um dos pioneiros no uso de materiais pouco familiares ao fazer pictórico, como: saco de juta ${ }^{(v)}$, plástico e barro, chegando a substituir o pincel pelo maçarico - assim como Yves Klein. A experimentação de Burri constituiu um vasto repertorio plástico que inseriu na pintura materialidades e visualidades que borraram os limites entre a representação e a apresentação ${ }^{(v)}$ do objeto. O artista foi uma das principais referências de Kounellis e da Arte Povera ${ }^{(v)}$. Em "Burri e Fontana", Kounellis descreve como a obra de Burri desempenhou um papel fundamental em sua formação.

\section{Cabelo}

O cabelo, em diversas culturas antigas do ocidente, era associado à força, à vitalidade e à alma do indivíduo. Nesse sentido, o corte ou a manutenção dos fios simbolizava mudanças ou conservação do estatuto do sujeito perante a sociedade. Kounellis utilizou cabelo humano em diversas peças e de diferentes modos: na forma de trança sobre chapas de ferro $^{(v)}$ (ver imagem 83), em instalações com performance ${ }^{(v)}$ (ver imagem 77, 79) e preenchendo sacos de juta (ver imagem 179).

\section{Café}

O café é um alimento que contém alto potencial energético. Em diversas peças produzidas por Kounellis, o café torrado ou moído, quase sempre, está associado a balanças de ferro ${ }^{(v)}$ (ver imagens 156, 31, 93). A construção imagética do café sobre a balança ${ }^{(v)}$ sugere a ideia de comércio: o café pesado para ser vendido, mas também a mensuração do peso do café corresponde a um contraponto gravitacional ao aspecto fugidio do cheiro desse material. No plano sensorial o café, por seu cheiro intenso, cria um campo aromático que, em determinadas exposições, resulta na antecipação ${ }^{(v)}$ da percepção olfativa em relação à visual, ou seja, por alguns instantes a visão perde sua preponderância no reconhecimento do trabalho. Por suas características, Kounellis associou o café ao conceito de sensibilidade ${ }^{(v)}$.

Em obra realizada em 1989, na galeria Pièce Unique, em Paris, Kounellis utilizou o café torrado e em grãos entre duas lâminas de vidro que formavam uma vitrine entre a rua e o espaço interno, criando um 

muro de café (ver imagem 152, 153). Nessa exposição individual, o cheiro do café antecipava a experiência do olhar, já que os grãos de café bloqueavam a visão das obras que estavam no interior da galeria.

O odor ${ }^{(v)}$ do café também remete aos cafés e bares europeus, de Paris a Viena, onde os artistas modernos se encontravam para conversar e debater os problemas da arte. Contudo, cabe lembrar que o café, segundo Marc Scheps, é "igualmente um lembrete histórico da escravidão e do comércio colonial que o trouxe para nossas lojas e o introduziu em nossa cultura"13.

Embora nunca citado por Kounellis ou por qualquer outro autor, associo o aroma do café à Exposition Internationale du Surréalisme realizada em 1938. Nessa exposição, segundo Marcel Duchamp, os surrealistas montaram "um fogareiro elétrico sobre o qual grãos de café eram torrados. Isso produzia um odor maravilhoso em toda a sala, e fazia parte da exposição" ${ }^{14}$.

\section{Cadeira}

A cadeira é um dos objetos que dentro da obra de Kounellis pressupõe a presença do ser humano, por sua escala ${ }^{(v)}$ e função. No entanto, a cadeira quase sempre foi utilizada como base para apoiar outros materiais e objetos. Raramente uma cadeira foi exibida "vazia", salvo quando, em grupos de doze, desenhavam no espaço expositivo um perímetro $^{(v)}$ circular que Kounellis preenchia com outros objetos ou materiais para criar um trabalho. Essa disposição circular e em conjunto

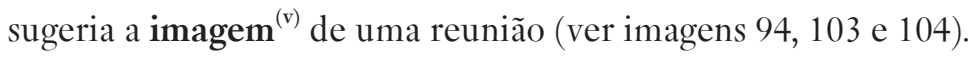

\section{Cama}

As dimensões da cama de solteiro $(200 \times 90 \mathrm{~cm})$ ou de casal $(200 \times 180 \mathrm{~cm})$ são para Kounellis escalas de $\operatorname{apresentação~}^{(\mathrm{v})}$ do humano. Nos anos 1970, Kounellis começou a usar camas de solteiro como estrutura $^{(\mathrm{v})}$ (ver imagens 85,86 ). Gradativamente, o artista transpôs para painéis de ferro ${ }^{(v)}$ as dimensões das camas de solteiro, substituindo, parcialmente, um objeto pelo outro (ver imagens 10, 18 e 24). Posteriormente, ao juntar duas chapas de $200 \times 90 \mathrm{~cm}$, Kounellis chegou à medida de $200 \times 180 \mathrm{~cm}$, a dimensão de uma cama de casal (ver imagens 38, 40, 195). Por meio desses painéis de metal, o $\operatorname{artista}^{(v)}$ continuou a articular o conceito de estrutura.
13 Sem título, 2004.

Estruturas de ferro em

forma de cruz sobre tapetes, gancho, casaco e chapéu. Foto: Manolis Baboussis.

14 Vista da cenografia para a peça Funerale, da un'immagine di fannis Kounellis, escrita por Roberto Lerici e dirigida por Carlo Quartucci, $7^{\mathrm{a}}$ Documenta, Kassel, 1982. Foto: Claudio Abate. 

A princípio, é inevitável não associar a escolha de Kounellis pela escala $^{(v)}$ da cama ao mito de Procrusto, que significa "aquele que estica". No mito, Procrusto era um assassino que

usava de uma "técnica" singular com suas vítimas: deitava-as em um dos dois leitos de ferro que possuía, cortando os pés dos que ultrapassavam a cama pequena ou distendia violentamente as pernas dos que não preenchiam o comprimento do leito maior. [...] reduzindo suas vítimas às dimensões que desejava ${ }^{15}$.

No entanto, Kounellis ao utilizar as medidas de leitos calibrou e definiu sua escala de trabalho, reiterando-a pelo constante uso das mesmas dimensões em diversas peças. Ao selecionar as medidas da cama como dimensões para suas estruturas, o artista delineou que os demais objetos e formas, adicionados ao trabalho - que corresponde ao conceito de sensibilidade ${ }^{(v)}$-, interagem em função da escala humana e, sucessivamente, da cultura. Ou seja, a presença do humano é o fio condutor das relações entre os demais elementos dos trabalhos, circunscrevendo-os dentro do domínio da cultura. Diferentemente de Procrusto que simboliza a redução do humano a uma medida predeterminada, Kounellis descreveu o perímetro $^{(\mathrm{v})}$ de sua prática artística por meio da escala humana. Tal escolha revela o interesse do artista pelo humanismo ${ }^{(\mathrm{v})}$.

\section{Caravaggio (1571-1610)}

Pintor italiano. Em "Caravaggio e o poder da sombra", Kounellis tece um elogio à obra do pintor, que para ele era fundamental para a compreensão da dramaticidade presente na produção artística italiana.

Para Kounellis, a pintura de Caravaggio correspondia imageticamente à ideologia da Contrarreforma Católica que, para responder à Reforma Protestante de Lutero, modificou os paradigmas de representação das figuras religiosas, conferindo a elas aspectos "mais humanos". Quando citava Caravaggio, Kounellis também frisava que se tratava de um momento nevrálgico da história da pintura, pois Caravaggio redefiniu a ideia da pintura a partir de seu processo de trabalho, ao conceber a superfície da pintura como um espelho que reflete a realidade.

A concepção da pintura como espelho de Caravaggio pode ser verificada em obras como Medusa, de 1597, pintada sobre uma superfície
15 Sem título, 1969. Chapa de ferro e vela. $100 \times 70 \mathrm{~cm}$. Foto: Claudio Abate. 


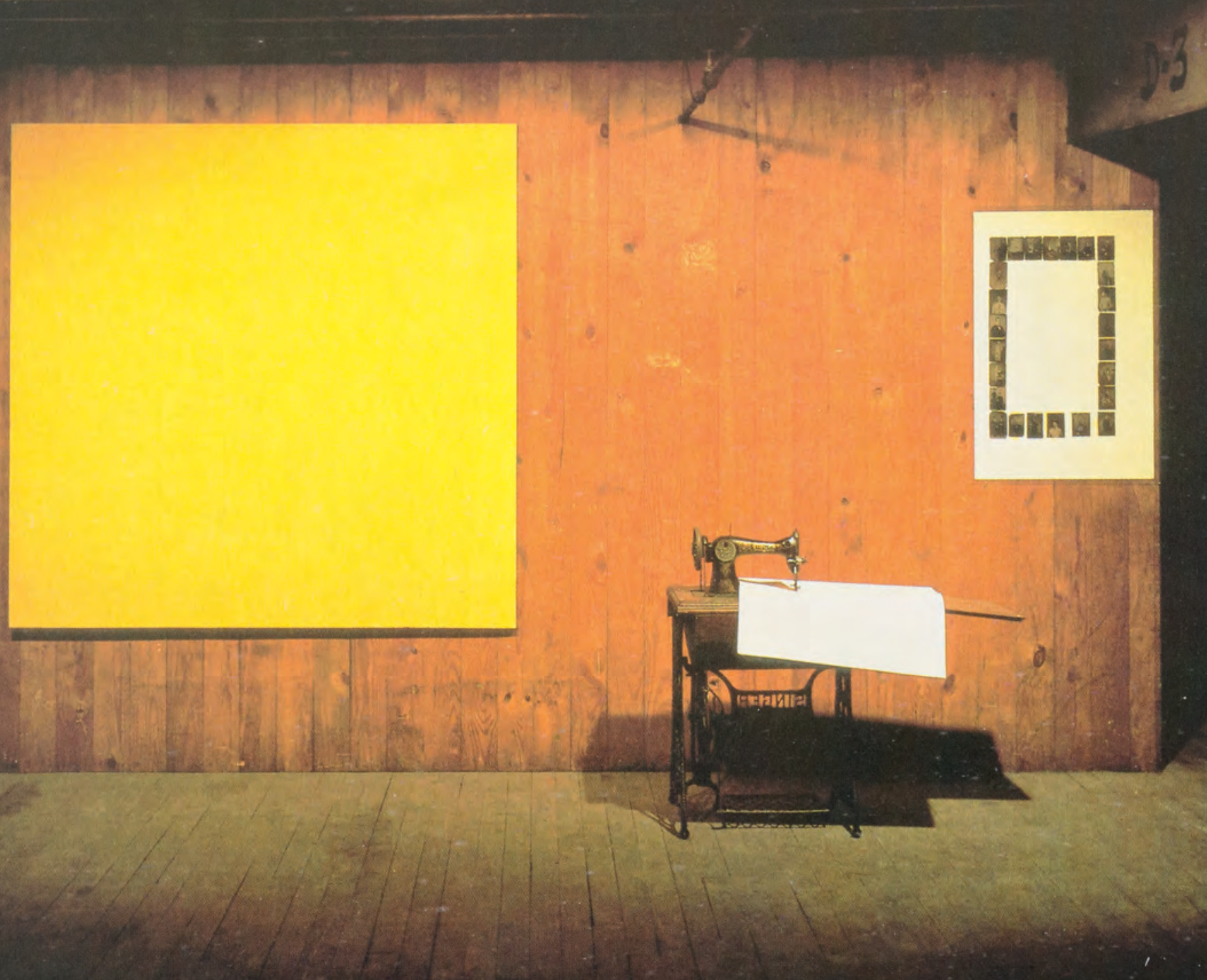


de formato circular que faz referência à forma escudo de Perseu que, além de circular, era convexo e espelhado. A imagem ${ }^{(v)}$ da cabeça decapitada corresponde ao reflexo da cabeça da górgona no escudo do herói no instante seguinte após a lâmina da espada realizar o corte.

A carga dramática da pintura é dada pela somatória das deformações da imagem da cabeça que se referem, a um só tempo, à expressão de dor, ao reflexo dado pela superfície espelhada e convexa do escudo e ao reflexo da face do próprio artista na superfície da tela.

Para estabelecer a pintura como espelho, Caravaggio precisou romper com a ideia renascentista da pintura como janela e da representação de modelos ideais. $\mathrm{O}$ pintor aboliu o uso de desenhos preparatórios ${ }^{16}$ para, então, pintar a partir daquilo que o olho vê, ou seja, sem recorrer a esquemas ideais. Ao optar por esse procedimento, Caravaggio eliminou a profundidade do espaço em perspectiva ${ }^{17}$ para conceber o espaço em termos de composição dramática, concentrando, assim, toda a ação de sua pintura no primeiro plano. Aqui, o controle das fontes de luz que iluminavam os modelos era fundamental para produzir as figuras que emergem e submergem no fundo negro, ponto-chave na construção de uma espacialidade modelada por luz e sombra.

Desse modo, a concepção pictórica de Caravaggio criou uma fissura dentro da linguagem ${ }^{(v)}$ da pintura de seu tempo, o que para Kounellis revelava também que não há neutralidade na linguagem. Toda escolha técnica e teórica corresponde a uma tomada de posição do artista, que promove através dessa uma declaração ${ }^{(v)}$.

\section{Caravana}

A caravana foi uma das formas de organização espacial dos objetos usada por Kounellis para a construção de uma obra ou exposição (ver imagens 12, 84 e 88). Diferentemente da afirmação ou demarcação do perímetro $^{(v)}$, a disposição em linha ou, melhor dizendo, em sequência estabelece outra dinâmica espacial entre observador e obra. Trata-se de uma dinâmica de partitura $^{(\mathrm{v})}$, que retoma aspectos visuais presentes em outras obras do artista cujas composições apresentam relações rítmicas com a litania ${ }^{(v)}$. Opto pelo termo caravana, pois a disposição dos objetos realizada por Kounellis parece, além de pontuar uma direção, determinar um sentido, embora tudo seja estático. Essa organização evoca as ideias de migração ${ }^{(v)}$ e viagem $^{(v)}$. Em 1982, em parceria
16 Sem título (Manifesto para um teatro utópico), 1973. Máquina de costura com papel costurado, pintura amarela, lamparina e colagem sobre papel com desenho. Foto: Claudio Abate.
160 ponto é controverso, pois não se sabe com segurança se Caravaggio produzia esboços e depois os destruía.

17 Nesse momento histórico existia uma limitação técnica que impedia a realização de pinturas ao ar livre, ou seja, o pintor realizava desenhos preparatórios e, posteriormente, transpunha-os para a pintura quando necessitava descrever uma paisagem no fundo de sua cena. 

com Carlo Quartucci, Kounellis realiza na $7^{\text {a }}$ Documenta de Kassel o espetáculo Funeral, a partir de uma imagem de Fannis Kounellis. A peça se

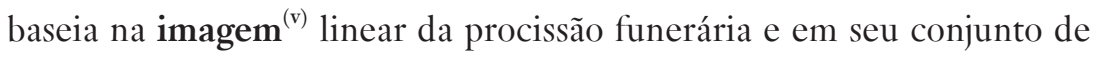
gestos e objetos específicos (ver imagem 14). Nessa obra, o cortejo era também uma caravana em deslocamento, o que para Kounellis, além de manifestar uma determinada identidade cultural, expressava também os ciclos de descoberta e esquecimento da sociedade.

\section{Carne}

A carne foi utilizada pela primeira vez na exposição de 1989 no Espai Poblenou, em Barcelona. Nessa exposição, grandes pedaços de carne, enganchados e montados sobre diversos painéis de metal de $200 \times 180 \mathrm{~cm}$ e sobre um grande painel de $200 \times 1330 \mathrm{~cm}$, estavam associados a lamparinas e maçaricos (ver imagens 18, 90, 136, 144 e 154). A carne, como objeto, evoca as pinturas Rembrandt, Soutine e Ticiano que retratam cenas de esfolamento. No entanto, Kounellis, ao associar os pedaços de carne às chapas de ferro ${ }^{(v)}$ (de dimensões similares a camas de casal e solteiro) e a lamparinas e maçaricos nas obras dessa exposição, criou uma imagem $^{(\mathrm{v})}$ que remetia à Guernica, de Pablo Picasso ${ }^{(v)}$. Em Guernica, a cena é iluminada por dois pontos de luz: um fixo no topo da pintura (a luminária com lâmpada) e outro que se projeta sobre as figuras (a lamparina). São esses pontos de luz que revelam os horrores contidos na cena, da mesma forma que a luz emitida por lamparinas e maçaricos tateia o espaço do trabalho de Kounellis [ver cama ${ }^{(\mathrm{v})}$ ].

\section{Carvão}

O carvão é uma fonte de energia e foi o principal combustível utilizado na Revolução Industrial. Segundo Kounellis, "ferro e carvão são os materiais que melhor evocam o mundo da Revolução Industrial, a origem da civilização contemporânea" ${ }^{\prime 1}$. As primeiras peças com carvão datam de 1967, mas foi apenas na segunda metade da década de 1980 que Kounellis usou o material em larga escala (ver imagens 117, 118, 119, 120, 121 e 131). Para Kounellis, o carvão e outros materiais "são portadores de uma 'nostalgia' e de um 'incomodo' [...] para os espectadores, que são positivamente condicionados a eles e os admitem como 'sinal' de alteridade e como 'indicadores' de não convencionalidade” ${ }^{\text {"1 }}$. O carvão é um elemento ligado ao conceito de sensibilidade ${ }^{(v)}$.
17 Sem título (Tragédia

Civil), 1975. Parede coberta com folhas de ouro, portacasacos, chapéu, casaco e lamparina. Foto: Mimmo Jodice.

18 Detalhe de Sem título, 1989. Chapas de ferro, pedaços de carne e maçarico presos por ganchos em tubos de metal. $200 \times 1330 \mathrm{~cm}$. Espai Poblenou, Barcelona, 19891990. Foto: Claudio Abate.
18 (KOUNELLIS;

CODOGNATO; D'ANGELO, 2002, p. 237).

19 (MOURE, 1990, p. 332). 


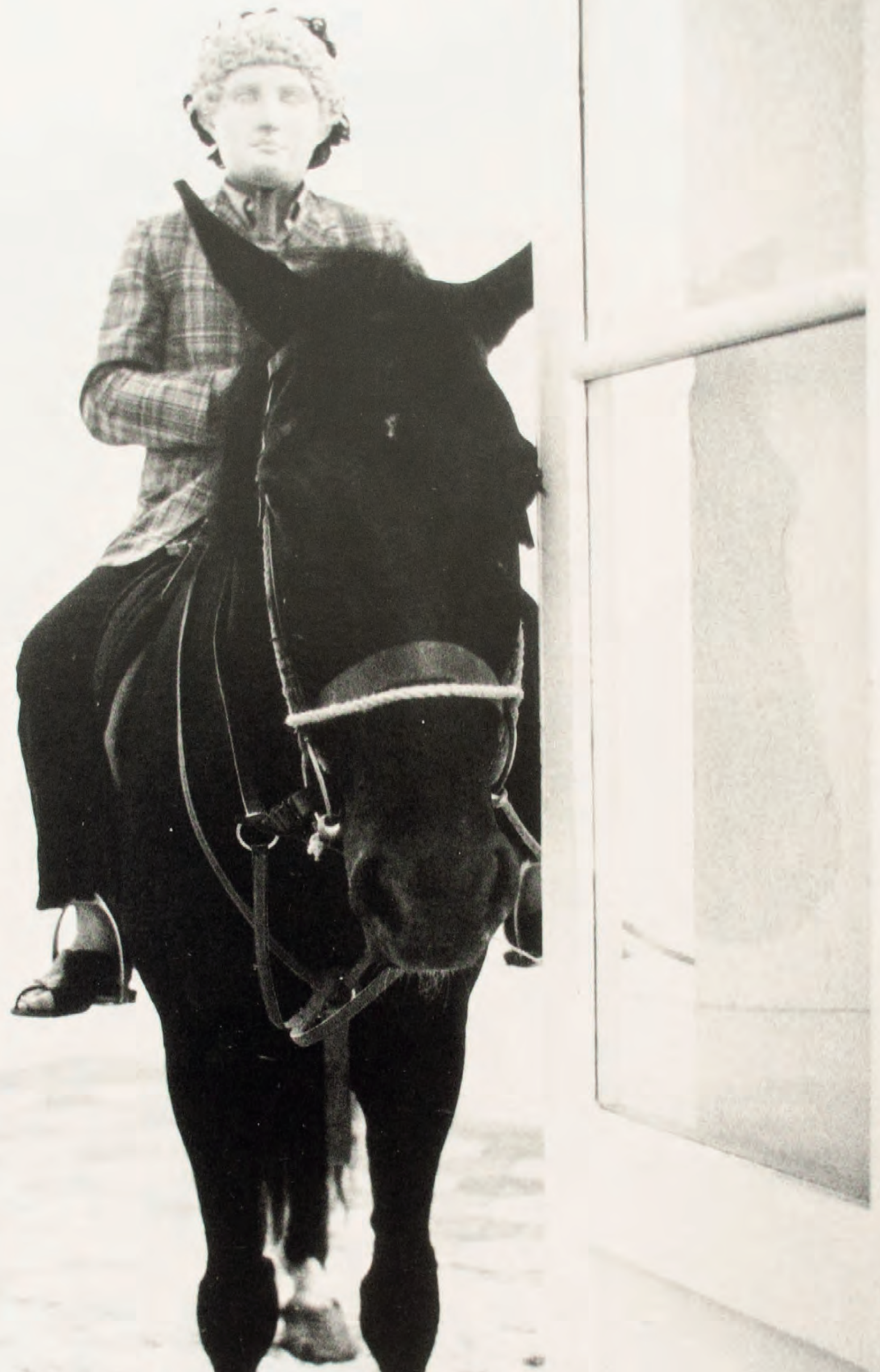




\section{Cavalo}

O cavalo é, talvez, a sensibilidade ${ }^{(v)}$ mais emblemática da poética de Kounellis. Ele foi usado pela primeira vez em 1969, na Galeria L'Attico (Roma), na obra Sem título (Cavalo), que de imediato tornou-se uma das obras fundamentais da Arte Povera ${ }^{(v)}$. Nessa peça, doze cavalos são distribuídos e amarrados no perímetro ${ }^{(v)}$ da galeria, convertendo-a num estábulo (ver imagem 160). Posteriormente, o cavalo reaparece em peças como: Sem título, de 1974; Funeral, a partir de uma imagem de Fannis Kounellis, de 1982; e Sem título, de 2016 (ver imagens 19, 14 e 1, respectivamente). A presença do cavalo nos trabalhos de Kounellis evoca um tempo anterior à industrialização, quando esse animal foi incorporado à vida social como meio de transporte e arma de guerra ${ }^{20}$. O cavalo é visto como um animal domesticado cuja força e potência estavam contidas pelo fato de ele estar amarrado, selado e confinado ao espaço da galeria. Porém, à disposição do artista, essa energia era libertada por meio de relações conceituais e percepções sensoriais. Por sua função, história e tamanho, o cavalo, diferentemente dos demais animais domesticados, suscita a presença do humano: de uma amazona ou de um cavaleiro, construindo um jogo de escalas que afirma o domínio da natureza pela cultura. Cabe ressaltar que a imagem ${ }^{(v)}$ do cavalo foi anteriormente trabalhada por outros artistas como Caravaggio $^{(v)}$, David ${ }^{(v)}$, Delacroix ${ }^{(v)}$ e Picasso ${ }^{(v)}$. Por conta disso, sua aparição em determinados trabalhos produz no observador uma série de associações imagéticas relacionadas à história da arte.

\section{Cavidade teatral}

A arte precisa de cavidades, uma cavidade. Uma igreja era uma cavidade. O teatro é uma cavidade. A pintura começou em cavernas. A pintura nas paredes está ligada ao perímetro de uma caverna, que mais tarde se tornou arquitetura, um grupo de sinais, sinais plásticos e, também, um local de culto, de afirmação da fé e da vontade de criar drama, teatro, em um sentido absolutamente não decorativo. A pintura sempre se apoia em um suporte. Mesmo ao ar livre, deve sempre ter um suporte. A imensidão não existe, apenas a relação entre uma escultura e uma praça da cidade existe, por exemplo, ou então entre uma escultura e a fachada de uma igreja. É sempre uma questão de relação ${ }^{21}$.

Uma galeria, na medida em que é um espaço público, como um museu, é basicamente uma cavidade teatral. É a sede de atos ou eventos únicos,
19 Sem título, 1974. Sala pintada de amarelo,

Kounellis montado a cavalo usando a máscara de Apolo e lamparina. Galeria L'Attico, Roma, 1974. Foto: Claudio Abate.
20 (BRANDÃO, 2007, p. 50).

21 (KOUNELLIS; CODOGNATO; D'ANGELO, 2002, p. 265). 

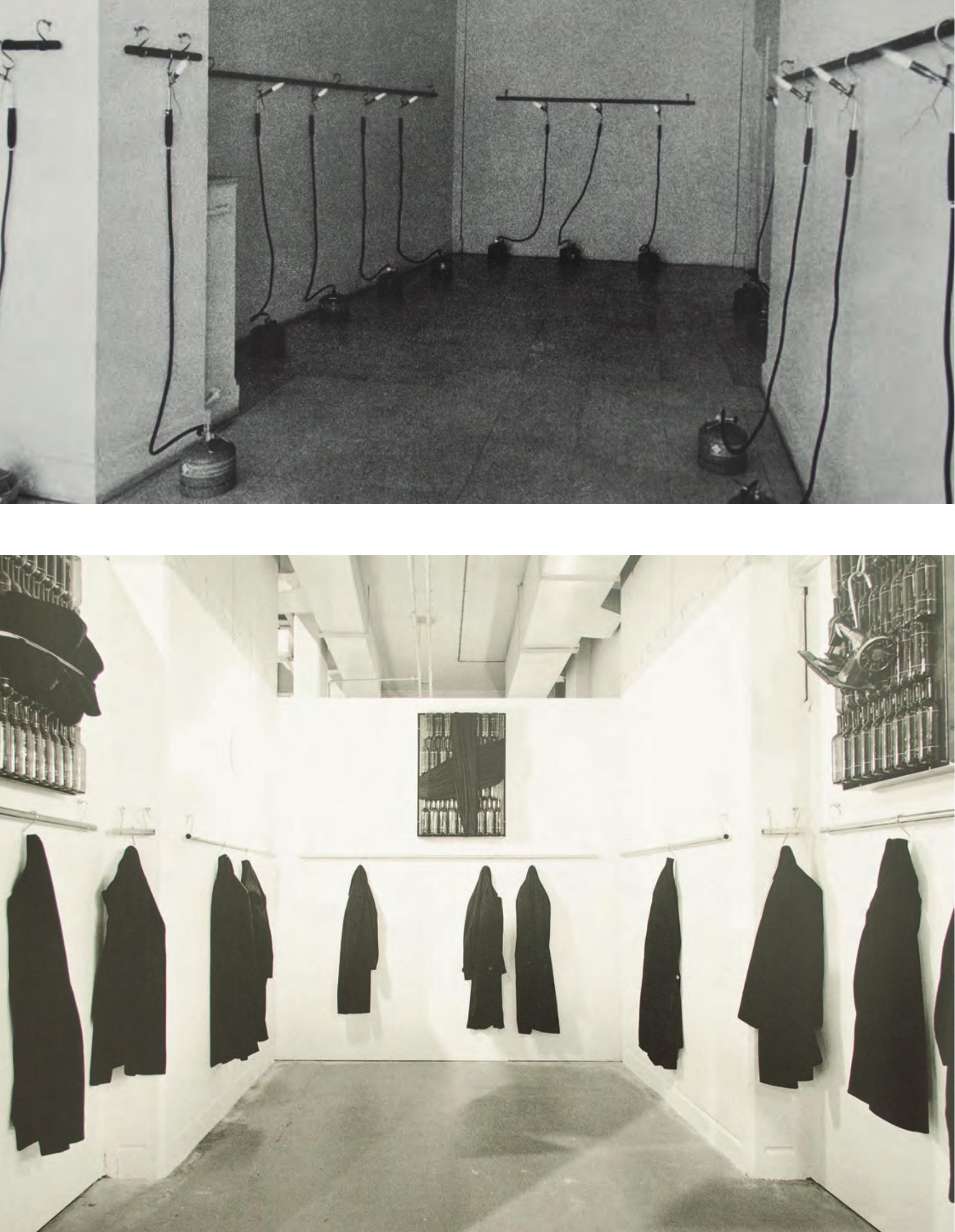
repetidas vezes. Portanto, os cavalos, que não eram cavalos livres, mas confinados aos limites da galeria, naquele espaço público chamado galeria, constituíam um ato único. Na verdade, o elemento, a indicação, acentuado na exposição de 1969 foi a consideração do espaço público ${ }^{22}$.

Kounellis, ao indicar o conceito de cavidade teatral, automaticamente, posicionou sua produção artística dentro de uma genealogia da produção plástica humana. E, por meio desse conceito, fica evidente porque Kounellis se denominava pintor $^{(v)}$. Podemos constatar que, para $o$ artista, a pintura ${ }^{(v)}$ era um meio cuja linguagem ${ }^{(v)}$ se constitui na relação com seu suporte; logo, supomos uma distinção entre afresco $^{(\mathrm{v})}$ e pintura sobre suportes móveis - pintura sobre papel, madeira ou tela esticada em chassi.

Em suma, Kounellis, ao formular o conceito de cavidade teatral, estabelece a relação entre pintura e suporte enquanto fundamento teórico do fazer pictórico. Logo, os doze cavalos na Galeria L'Attico (ver imagem 160) ou o papagaio ${ }^{(v)}$ repousado sobre um poleiro fixado numa chapa de ferro ${ }^{(v)}$ com as dimensões de uma folha de papel Fabriano ${ }^{(v)}$ (ver imagem 51) são pinturas, pois se articulam em relação a um suporte que oferece o contexto da arquitetura do espaço expositivo ${ }^{(\mathrm{v})}$, no primeiro caso, e do painel de metal, no segundo. Por fim, cabe frisar que o contexto expresso pelo suporte corresponde ao conceito de estrutura $^{(v)}$.

\section{Catedral}

Kounellis, no decorrer da carreira e, em especial, na entrevista com Joseph Beuys, Anselm Kiefer e Enzo Cucchi ${ }^{23}$, manifestou o que definiu como um desejo por centralidade ${ }^{(v)}$ e verticalidade $^{(v)}$, que se materializaria, segundo ele, na imagem ${ }^{(v)}$ de uma catedral. Para Kounellis, a catedral como edificação era o produto do esforço combinado de vários saberes, sendo o símbolo de um pacto do avanço técnico e da construção artística e cultural no qual todas as artes estão presentes e são pensadas para interagir em conjunto, potencializando-se mutuamente. As considerações de Kounellis sobre a catedral encontram paralelos no ensaio de Auguste Rodin sobre as catedrais francesas ${ }^{24}$. Nesse texto, Rodin pontua como a catedral redefine o espaço urbanístico da cidade, construindo uma imagem sintetizada do que está ao redor e, também, de como os mestres do gótico trabalhavam em conjunto:
20 Sem título, 1969

Maçaricos pendurados em tubos de metal com ganchos (cilindros de propano no chão). Galeria Iolas, Paris, 1969. Foto: Claudio Abate.

21 Vista da exposição Jannis Kounellis, Ambika P3, Londres, 2010. Foto Manolis Baboussis.
22 (KOUNELLIS; CODOGNATO; D'ANGELO, 2002, p. 252).

23 (BEUYS; CUCCHI: KIEFER; KOUNELLIS, 1986a). Uma versão reduzida da entrevista foi publicada em 1986 na revista Flash Art, número 128, sob o título "The cultural-historical tragedy of the European Continent".

24 Cf. Rodin (2002). 


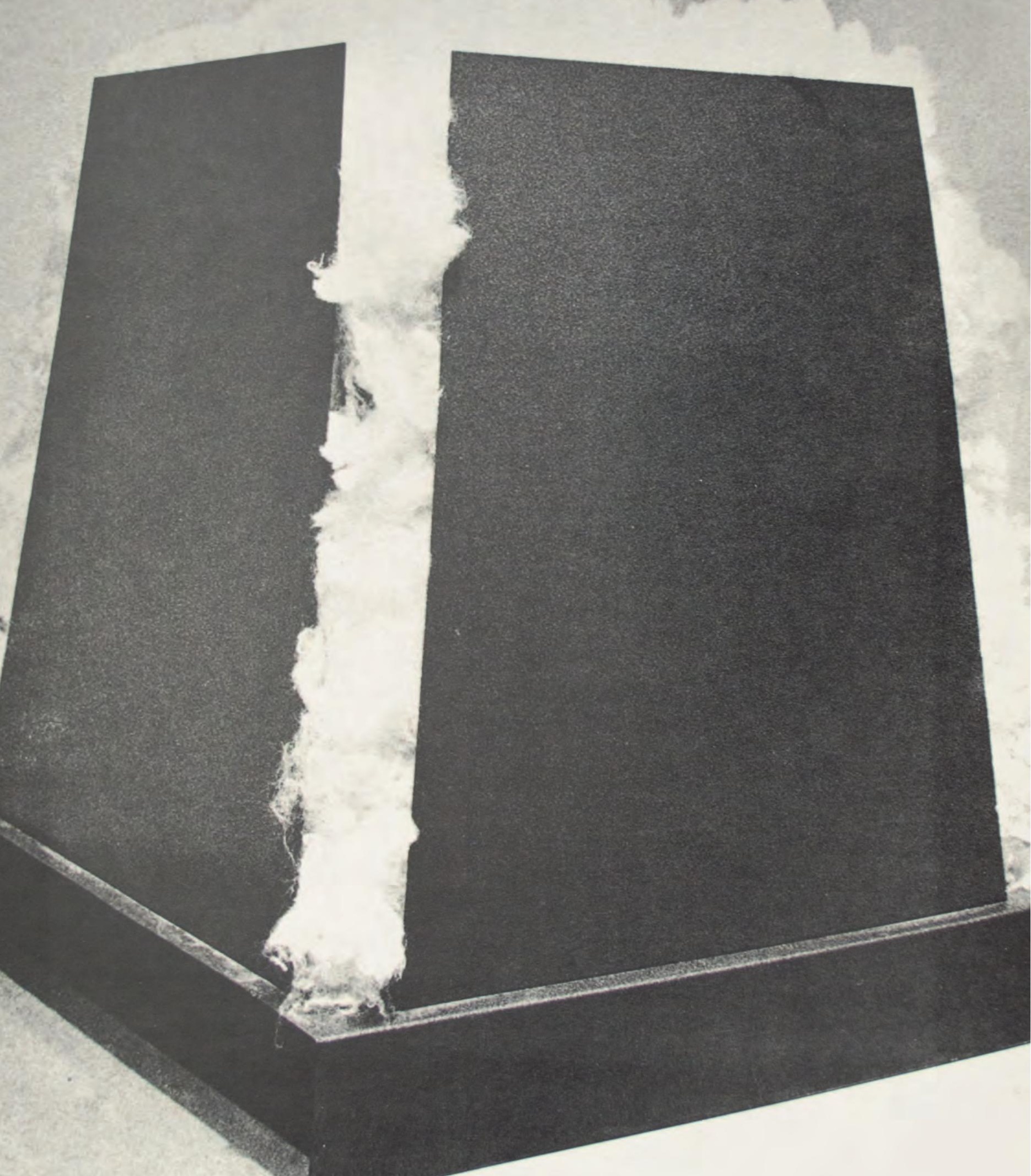


A catedral se elevava para dominar a cidade reunida em torno dela, como se debaixo de asas protetoras, para servir de ponto de reunião, de refúgio, aos peregrinos perdidos nas estradas longínquas, para ser o farol deles para atingir os olhos vivos tão longe no dia quanto os ângelus e os toques a rebate podiam atingir na noite os ouvidos vivos. [...] Como era verdadeiro, justo e fecundo o método dos nossos velhos mestres dos séculos XI ao XVIII! Esse método é, em grande escala e na união de todas as forças humanas de uma época, o mesmo método de nossas atividades individuais, quando bem conduzidas: a colaboração do homem com a natureza. [...] A catedral é a síntese do país. Repito: rochas, florestas, jardins, sol do Norte, tudo isso está presente, resumido, nesse corpo gigantesco, toda a nossa França está nas catedrais, como toda a Grécia está resumida no Partenon ${ }^{25}$.

Para Mircea Eliade, a catedral, assim como o templo e a basílica, "não é somente uma imago mundi, mas também a reprodução terrestre de um modelo transcendente ${ }^{226}$. Em $O$ sagrado e o profano, Eliade também comenta a experiência da centralidade e da verticalidade como marcos da fundação de um espaço sagrado, em relação à continuidade, homogeneidade e neutralidade do espaço profano. Em outras palavras, trata-se do estabelecimento de um "ponto fixo" apontado, por meio de uma hierofania, ao homem religioso que reconhece o lugar revelado como o "centro", sendo o altar uma forma primária "vertical" que conecta o fiel ao seu deus.

No caso da catedral a edificação é centralidade e verticalidade, conforme assinalou Rodin. No entanto, apesar das inúmeras referencias espirituais e místicas que a ideia de catedral pode conter, devo assinalar que o interesse de Kounellis por essa imagem resgata a ideia de Rodin da catedral como síntese cultural, não apenas francesa, mas europeia. A catedral como obra concluída exibe o resultado dos esforços combinados de uma época possibilitado pela acumulação ${ }^{(v)}$ técnica e teórica, além de demarcar, historicamente, o início da passagem do campo para a cidade. E, tendo em vista "O julgamento de K.", podemos afirmar também que a catedral, para Kounellis, foi uma metáfora para a criação de sua linguagem ${ }^{(v)}$ artística.

É importante frisar que ao evocar a imagem da catedral, Kounellis estabeleceu para sua produção artística um determinado tipo de experiência que nega a ideia de que a arte se dissolve na vida. Para ele, a experiência da arte acontecia apenas na cavidade teatral ${ }^{(v)}$, sendo a catedral um dos espaços que exemplificava esse conceito. Porém, apesar de não partilhar da ideia da junção entre arte e vida, Kounellis reconhecia que determinadas proposições artísticas conseguiam suspender temporariamente a fronteira entre esses dois campos.
22 Sem título (Algodão), 1967. Estrutura de ferro e algodão. $150 \times 120 \times 120 \mathrm{~cm}$. Foto: Claudio Abate. 



\section{Centralidade}

O conceito de centralidade, expresso na metáfora da construção de uma catedral $^{(\mathrm{v})}$, foi criado e desenvolvido por Kounellis a partir da década de 1980, tanto em textos quanto em entrevistas, como "O julgamento de K." e "Para meus alunos em Düsseldorf”, por exemplo. Para Mircea Eliade, a definição do centro dada por um "ponto fixo" é fundamental para o homem religioso, dado que "a partir de um Centro projetam-se os quatro horizontes nas quatro direções cardeais" ${ }^{27}$, complementando que "a descoberta ou a projeção de um ponto fixo - o 'Centro' - equivale à Criação do Mundo" 28 . Logo, para Eliade, estabelecer um "centro" significa definir um ponto de orientação dentro da homogeneidade caótica do espaço profano. Transpondo as ideias de Eliade para o campo da arte, em especial para a poética de Kounellis, podemos supor que, quando Kounellis referia-se à centralidade, o fazia para reportar-se à linguagem ${ }^{(v)}$ artística e ao modo como os artistas desenvolveram objetos que fundaram experiências sensoriais diferentes das experiências do mundo ordinário, redefinindo, assim, o modo como o observador comumente percebe e se orienta.

Vislumbro a ideia de centralidade também na relação entre estrutura $^{(v)}$ e sensibilidade ${ }^{(v)}$, na qual elementos vivos ou orgânicos (sensibilidade) eram contidos ou resguardados por estruturas - metálicas e arquitetônicas - que, simbolicamente, aludiam à ideia de cultura. Em outras palavras, a cultura envolve, parcialmente, os elementos do mundo e da vida, conferindo-lhes sentido dentro de uma linguagem que se refere ao humano. No interior da linguagem, instituída a partir de um centro, objetos, formas, elementos vivos e materiais adquirem valores e significados específicos partilhados por todos aqueles que a conhecem e a praticam.

Em suma, a centralidade para Kounellis diz respeito à linguagem da arte executada e entendida pelo $\operatorname{artista}^{(v)}$ que, segundo ele, era também seu guardião(v). E, conforme Kounellis assinala em "Para meus alunos em Düsseldorf", a verticalidade ${ }^{(v)}$ é o passo seguinte, após o estabelecimento do centro.

Cézanne, Paul (1839-1906)
23 Sem título, 1985 Chapas de metal, base de cama e fragmentos de madeira. Exposição fannis Kounellis, Museu de Arte Contemporânea, Montreal, 1987. Foto: Claudio Abate.

24 Sem título, 1985.

Chapas de metal, base de cama, fragmentos de madeira e vigas de metal. $391 \times 575 \mathrm{~cm}$. Exposição fannis Kounellis: uma retrospectiva em cinco lugares, Museu de Arte Contemporânea de Chicago, Chicago, 1986 Foto: Claudio Abate. 


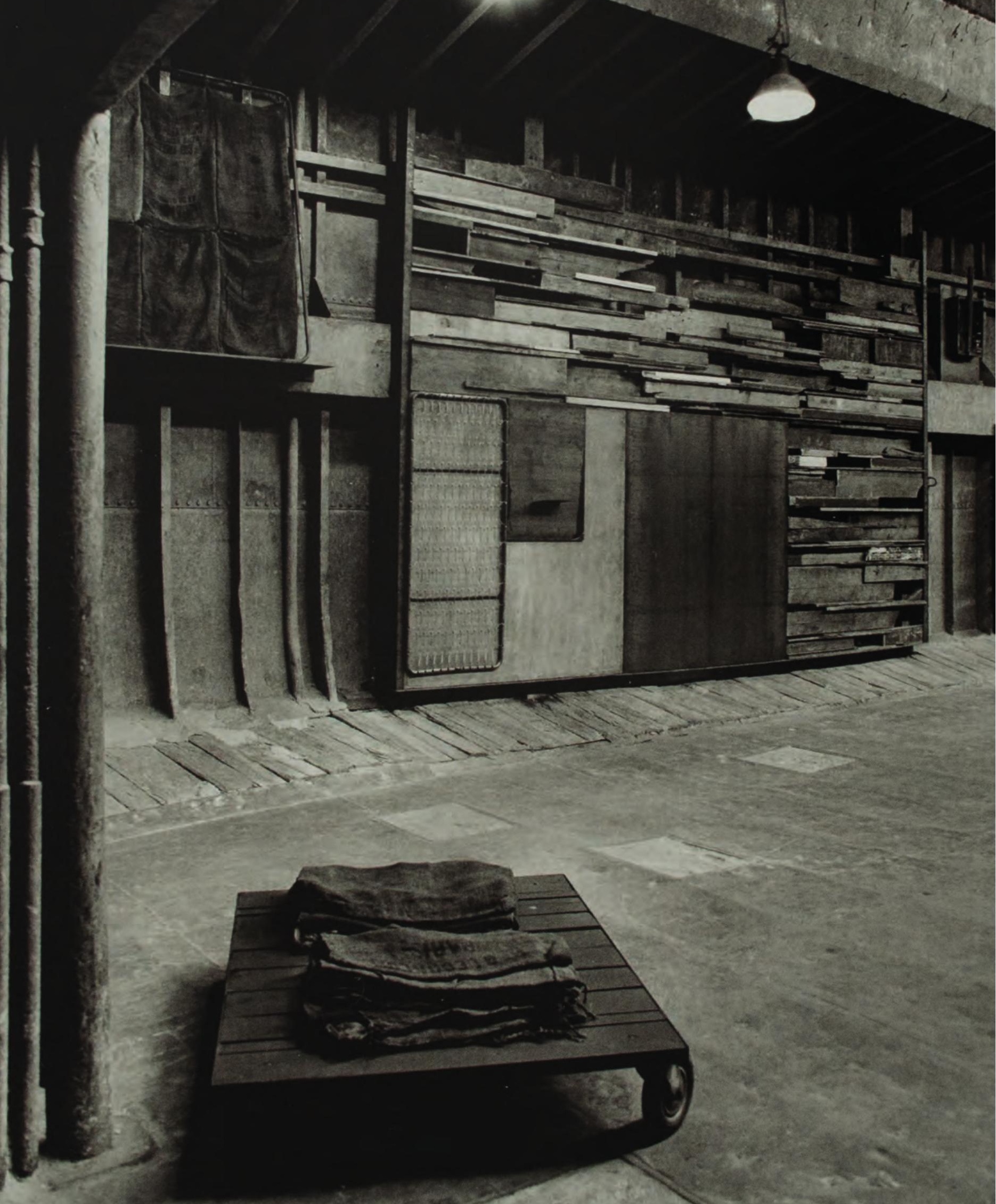


pela escolha e apresentação ${ }^{(v)}$ do objeto e seus desdobramentos interpretativos certamente encontra parte de suas raízes em Cézanne.

Embora pouco citada por Kounellis, a obra de Cézanne desenvolveu no interior de sua linguagem ${ }^{(v)}$ pictórica diversos procedimentos presentes na poética de Kounellis, em especial, a capacidade de evocação suscitada pela escolha dos objetos.

A maçã, por exemplo, evoca o mito do julgamento de Páris, em que o jovem pastor Páris escolhe Afrodite, em detrimento de Hera e Atena, como merecedora de uma maçã de ouro ${ }^{(v)}$, aspirando o amor da mulher mais bela do mundo naquele momento, Helena. No caso de Cézanne, a maçã também simboliza o tempo da terra e dos ciclos produtivos, pois tudo o que o ser humano possui é resultado da diligência que envolve o cultivo. Tendo em vista esse esforço, presentear com a maçã sugere um gesto de profundo apreço.

Cézanne, ao escolher a maçã como objeto representado, tinha plena consciência desses significados ${ }^{29}$ e os usou em suas pinturas para que o observador recebesse a imagem $^{(v)}$ da maçã, que lhe era familiar, envolta numa linguagem pictórica diferente da linguagem em perspectiva tradicional. O reconhecimento do objeto pintado e sua associação ao seu referente real atestavam a capacidade da linguagem de Cézanne em descrever a natureza das coisas.

Outro dado referente à escolha do objeto, em minha opinião, está nas pinturas tardias de Cézanne, nas quais o artista deixou visível parte da lona da tela, fazendo com que esta se tornasse um valor pictórico. Aqui enxergo uma operação cujo desenvolvimento linguístico resulta no procedimento da apresentação $^{(\mathrm{v})}$ do objeto presente tanto nas vanguardas modernas, através do ready-made e do objeto trouvé, quanto na obra de Kounellis.

\section{Chaminé}

A chaminé foi uma imagem ${ }^{(v)}$ trabalhada por Kounellis em desenhos, objetos e instalações a partir de meados da década de 1970. A chaminé suscita as imagens da fábrica e da locomotiva ${ }^{(v)}$ que, consequentemente, evocam a Revolução Industrial que, segundo Kounellis, foi a origem da civilização contemporânea. Em 1976, na Galeria Salvatore Ala, em Milão, Kounellis construiu um forno com chaminé que durante algum
25 Vista da exposição fannis Kounellis. Navio Cargueiro Ionion, Pireu, 1994. Foto: Aurelio Amendola e Manolis Baboussis. 

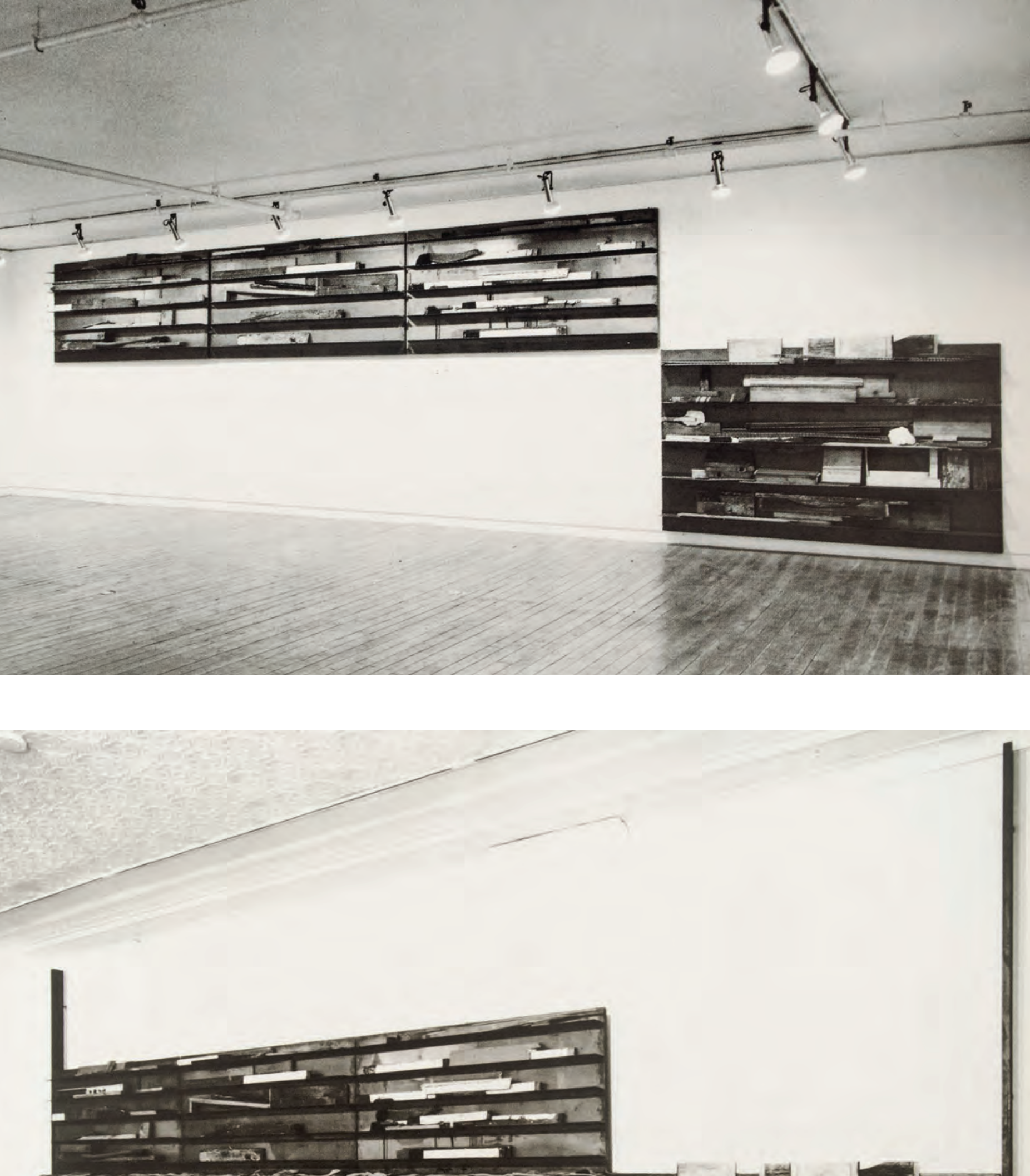

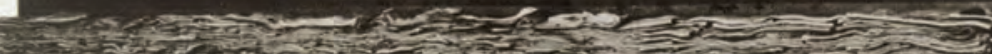

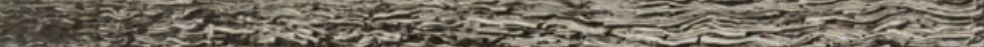

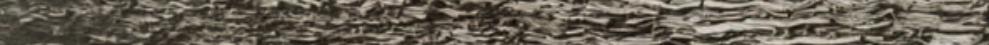

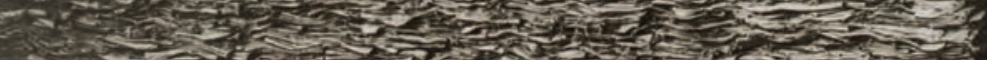

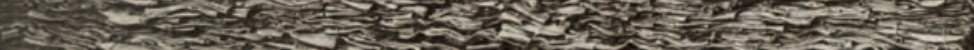

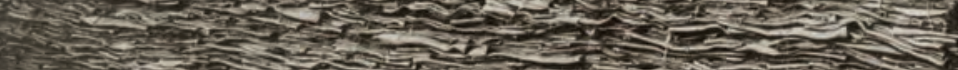

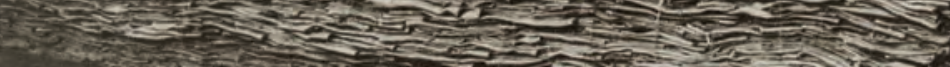

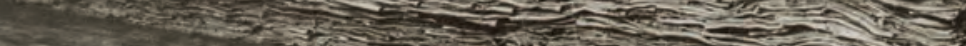
SAd

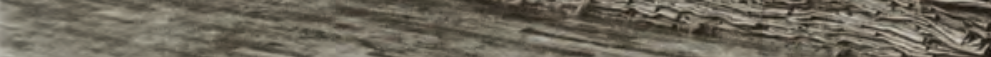

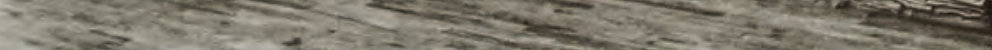

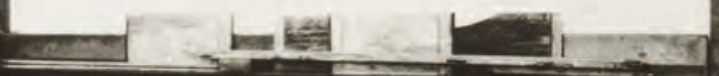

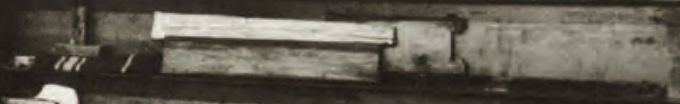

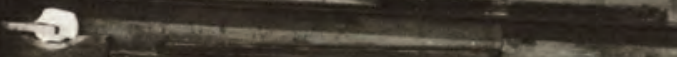

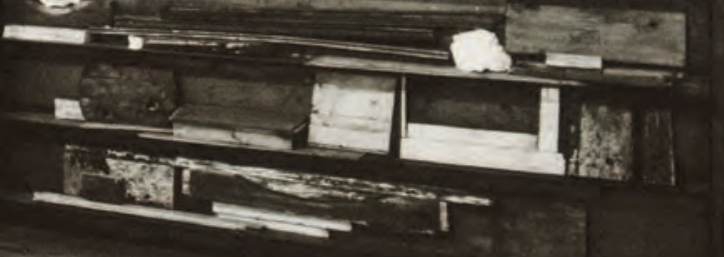

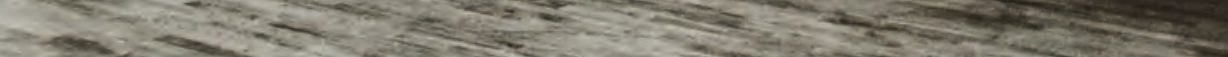

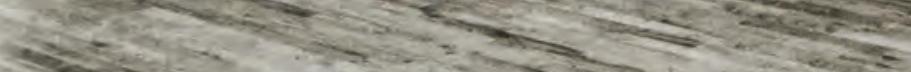


tempo foi ligado, produzindo nas paredes do espaço expositivo uma

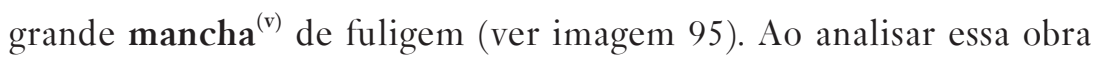
individualmente e à sombra dos textos do artista, encontramos uma série de referências à história da pintura ${ }^{(v)}$ e da arte, como os ciprestes de Munch $^{(v)}$ e Van Gogh ${ }^{(v)}$.

Contudo, gostaria de pontuar como essa obra reitera aspectos relacionados à ocupação do espaço presente em peças produzidas anteriormente pelo artista. Na primeira metade da década de 1970, Kounellis realizou um conjunto de performances nas quais músicos contratados executavam fragmentos de peças de música ${ }^{(v)}$ erudita, in loco e ao vivo (ver imagem 47 e 75 ). Apesar da fumaça ${ }^{(v)}$ e música serem o resultado de ações e gestos específicos sobre determinados materiais e objetos, e instaurarem diferentes modos de ocupação do espaço, a música dessas performances, assim como a fumaça na obra de 1976, tateia o espaço expositivo(v) ${ }^{(v)}$ por ele se dissipa. No entanto, cabe frisar que a percepção auditiva ocorre simultaneamente ao tempo de execução da música, enquanto a impregnação pela fuligem permanece após o desligamento do forno com chaminé [ver performance $\left.{ }^{(v)}\right]$.

\section{Coluna}

A coluna é um elemento arquitetônico que possui função estrutural e simbólica dentro do edifício, de acordo com a finalidade deste. A coluna foi usada por Kounellis, inicialmente, em obras com locomotivas de brinquedo. Nessas peças produzidas em 1977, os trilhos do trem em miniatura produziam dois tipos de trajetória, uma cíclica e outra helicoidal, mas ambas articuladas em função de um eixo vertical formado por sua respectiva coluna, ou seja, as locomotivas construíam a imagem $^{(v)}$ de uma viagem ${ }^{(v)}$ que delineava a centralidade ${ }^{(v)}$ e a verticalidade $^{(v)}$ dessas colunas. É importante pontuar que nessas obras Kounellis fez uso de colunas já presentes no espaço expositivo ${ }^{(v)}$ tanto no Claustro da Igreja de Santa Maria Novella, no caso do trilho de percurso cíclico, quanto no Estúdio Tucci Russo, no do trilho helicoidal (ver imagens 2 e 174).

Em 1997, portanto vinte anos após as primeiras peças de coluna com locomotiva ${ }^{(v)}$, Kounellis apresentou no Museu Ludwig, em Colônia, sete colunas helicoidais com quatorze metros de altura cada, e em apenas uma delas foi colocada uma miniatura de locomotiva. Diferentemente das obras de 1977 que incorporavam a arquitetura, as
26 Sem título, 1983.

Chapas de metal com prateleiras, fragmentos de peças de gesso e madeira parcialmente pintados. $487 \times 964 \times 45 \mathrm{~cm}$. Foto: Jon Abbott.

27 Sem título, 1985.

Chapas de metal com

prateleiras, fragmentos de peças de gesso e madeira parcialmente pintados; sacos de juta e vigas de ferro. $487 \times 964 \times 45 \mathrm{~cm}$. Foto: Paolo Mussat Sartor. 


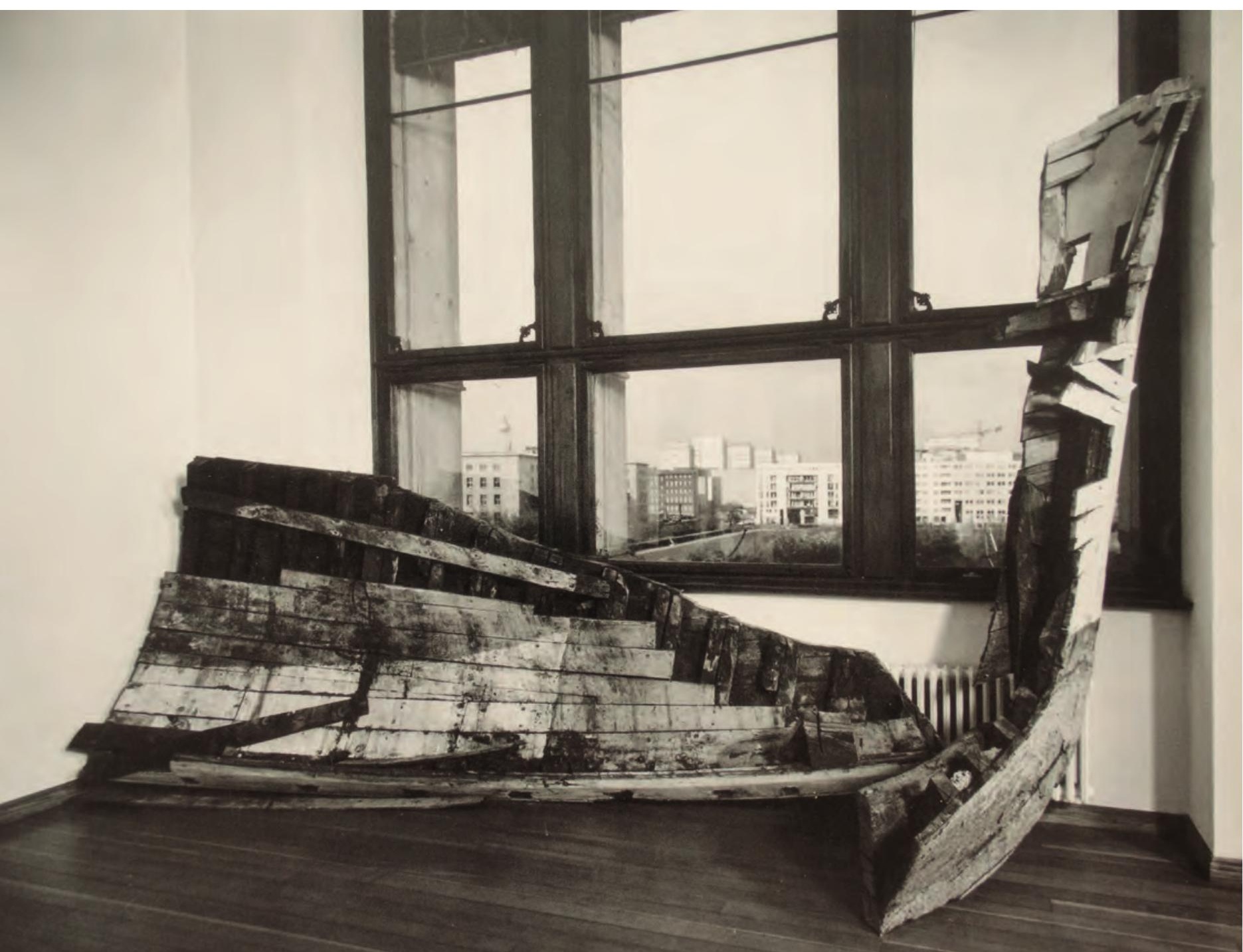


colunas helicoidais de Colônia foram fabricadas por Kounellis e, por não possuírem qualquer função estrutural em relação ao espaço expositivo, foram dispostas assimetricamente no espaço (ver imagem 101). Segundo Marc Scheps, no livro Kounellis stations on an odyssey, Kounellis mantinha em seu ateliê uma reprodução do desenho de Francesco Borromini da coluna e capitel do baldaquino da Basílica de São Pedro, como referência para as obras com colunas.

Em 1991, para a exposição na Sinagoga de Stommeln, em Pulheim, na Alemanha, Kounellis produziu novamente uma obra a partir da forma da coluna. Dessa vez, três colunas de madeira e pedra ${ }^{(v)}$ reforçam imageticamente a estrutura $^{(v)}$ da sinagoga, dialogando com a história do edifício que, durante a Segunda Guerra Mundial, abrigou pessoas perseguidas pelo regime nazista (ver imagem 142). Simbolicamente, as três colunas desenham no espaço metade da Estrela de Davi, um dos principais símbolos do judaísmo.

\section{Cortina}

A cortina é um elemento que, além de pertencer à arquitetura do palco de teatro, faz parte também da iconografia e do imaginário da pintura, ao menos, desde o célebre embate entre Zêuxis e Parrásio narrado por Plínio, o Velho ${ }^{30}$. Nos anos 1980, Kounellis começou a produzir trabalhos cenográficos para o teatro ${ }^{(v)}$ cuja visualidade estabelecia a dinâmica de uma cortina no espaço cênico. Na mesma década, Kounellis transpôs para o espaço expositivo ${ }^{(v)}$ essas cenografias, desenvolvendo, a partir delas, novas obras. Essas cortinas criadas em diferentes materiais e escala subdividem fisicamente o espaço, no entanto não obstruem a visão e a passagem do observador (ver imagens 80, 138, 171 e 172).

\section{Courbet, Gustave (1819-1877)}

Pintor francês. Pouco citado nominalmente por Kounellis, Courbet é uma referência que aparece em algumas publicações organizadas pelo artista, através de aproximações visuais entre Sem título (Papagaio), de 1967 (ver imagem 51), e a pintura Mulher com papagaio, de Courbet, de $1866^{31}$.

Courbet foi um dos primeiros artistas a pintar certos fenômenos naturais, entre eles, as tempestades marítimas. Para conseguir atingir um certo grau de instabilidade e imprecisão na representação destas
28 Sem título (Albatroz), 1991. Fragmento de barco. Foto: Claudio Abate.

\footnotetext{
30 “Tendo este [Zêuxis] pintado uvas com tal perfeição que aves voaram até a cena, na sua direção, Parrásio pintou uma cortina com um realismo tão grande que Zêuxis, todo orgulhoso com o veredito dos pássaros, reclamou que se abrisses, finalmente, a cortina para exibir a pintura. Percebendo seu erro, concedeu a palma ao outro com franca modéstia, uma vez que 'ele enganara aves, mas Parrásio a ele próprio, um artista'" (LICHTENSTEIN, 2014 , p. 75).
} 31 Ver Kounellis e Fuchs (1981). 

tormentas, o pintor ${ }^{(v)}$ utilizou massas de tinta aplicadas sobre a tela com o auxílio de uma espátula. O resultado desse procedimento técnico foi a sobreposição do pictórico ao linear para expressar o caráter informe das tempestades. Desse modo, Courbet borrou a fronteira entre a imagem representação - e o meio - pintura -, pois nessas pinturas de tormentas marítimas a matéria pictórica, em sua franqueza, é também a imagem; logo, há também uma nova teorização sobre a pintura ${ }^{(\mathrm{v})}$.

Já em Mulher com o papagaio, a ave agarra o dedo da modelo, que é obrigada a mudar de posição para tentar se esquivar do ataque, ou seja, o que Courbet representou nessa pintura foi a impossibilidade de contenção da natureza. O papagaio é tão instável e imprevisível quanto a tempestade, e posar não faz parte de sua condição. Ao representar a investida do animal sobre a modelo, Courbet rompe com a ideia de realismo presente na ideia de pintar exclusivamente aquilo que se vê, pois o papagaio em sua condição natural de força viva revela que toda a cena foi construída para a pintura, o que significa um esforço cênico para criação de uma situação realista. Em outras palavras, o papagaio revela a condição de atuação da modelo e, por conseguinte, o caráter ficcional da representação realista.

Em "Pensamentos e observações sobre o corpo, sobre o comportamento, sobre o 'natural' e sobre o 'viver' como autenticidade teatral", de 1968, Kounellis abordou essa fronteira entre a arte e a vida, tendo em vista sua experiência como artista e cenógrafo.

David, Jacques-Louis (1748-1825)

Pintor francês. No século XVIII, o Iluminismo representou o golpe final no ordenamento divino das coisas, na medida em que as Luzes propunham uma nova ordem baseada na "razão como crítica e guia a todos os campos da experiência humana" ${ }^{32}$. No campo da arte ocorre um novo retorno aos valores greco-romanos, mediado pelas experiências do Renascimento Italiano, em especial, pelo sistema da perspectiva; contudo, os temas clássicos começam a ceder espaço para temas contemporâneos. A obra de David, nesse contexto, desenvolve um programa que assimila os valores clássicos para usá-los na construção de temas contemporâneos.

Acredito que o interesse de Kounellis pela obra de David reside na sensibilidade do $\operatorname{artista}^{(v)}$ em transpor para a pintura ${ }^{(v)}$ sua realidade
29 Sem título, 1993. Velas de barco e cordas. Foto: Claudio Abate.

30 Sem título, 1995. Vigas de madeira e painéis de metal apoiados sobre a parede. Foto: Aurelio Amendola. 


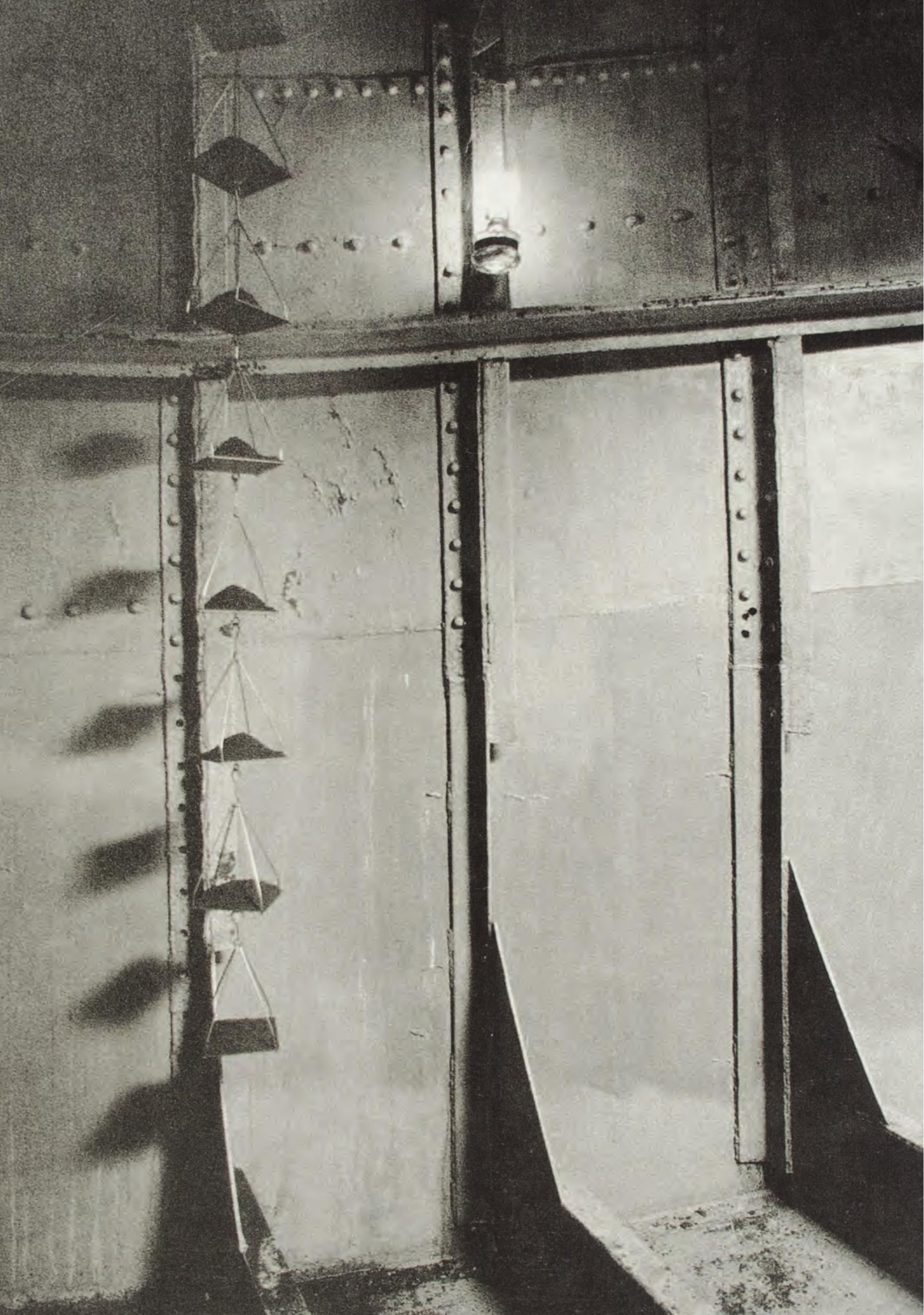


histórica. Ao inserir em sua obra conteúdos contemporâneos, em especial, aqueles que se referiam à Revolução Francesa, David não delegou à pintura uma tarefa "jornalística"; ao contrário, suas obras foram uma declaração ${ }^{(v)}$ e expressaram de forma clara e direta os ideais propostos pela Revolução. Em outras palavras, a pintura de David não se deteve na descrição dos fatos, já que ele criou símbolos revolucionários, sendo o pintor $^{(\mathrm{v})}$, inclusive, ligado aos jacobinos.

\section{Declaração}

Na minha individual de Berlim em 1990, quando o Muro caiu, reativei um velho carrinho cheio de sacos de carvão, fazendo-o ir de um lado para outro em trilhos que juntavam duas partes de um edifício abandonado. A exposição abriu no dia 13 de setembro e fechou no dia 2 de outubro, último dia da República Democrática Alemã. Isso é apenas para ressaltar o fato de que mostrar em uma galeria ou em um museu, é planejado como uma visão direcionada e simbólica. No século XIX não existiam exposições individuais. Existiam apenas exposições coletivas onde cada artista mostrava o seu melhor trabalho. Isso não lhes deu uma chance de fazer uma declaração. Cada artista hoje pode indicar algo com uma individual porque seu papel é mais forte. Ele tem sua própria identidade de pensamento e liberdade intelectual ${ }^{33}$.

Kounellis compreendia o fazer artístico, a exposição e os escritos dos artistas como atos políticos em que o $\operatorname{artista}^{(v)}$ expressava uma visão de mundo e um direito de liberdade inegociável, como podemos ver também em "Eu nunca matei ninguém, mas estou disposto a fazê-lo". Porém, a afirmação de Kounellis sobre as exposições individuais é parcialmente verdadeira. No século XIX, o salão de arte ainda era o lugar hegemônico de exibição dos trabalhos de arte; no entanto, em 1855, Gustave Courbet $^{(v)}$ constrói e apresenta, em paralelo ao salão oficial, o Pavilhão do Realismo. Essa mostra foi documentada em um catálogo com prefácio escrito por Courbet. E, em 1867, tendo a experiência de Courbet como referência, Édouard Manet elaborou o seu próprio pavilhão, em paralelo à Feira Mundial de Paris. Contudo, Manet optou por um texto anônimo e em terceira pessoa para o prefácio de seu catálogo.

Delacroix, Eugène (1798-1863)

Pintor francês. Delacroix foi um artista extremamente hábil na produção pictórica e na análise de obras. Desse modo, além de sua 
obra artística, outro grande legado de Delacroix são seus diários, nos quais o artista descreveu o exame minucioso que realizou das obras dos grandes mestres e, também, de seus contemporâneos. No entanto, para Kounellis, a grande contribuição do pintor $^{(\mathrm{v})}$ para a história da

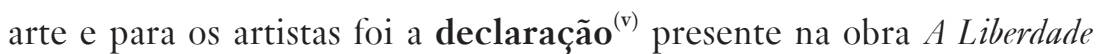
guiando o povo, de 1830. Nessa pintura vemos uma mulher simbolizando a liberdade e guiando para a batalha um grupo de homens, cada qual representando um segmento da sociedade. Sobre essa pintura, Kounellis afirma:

É uma imagem perfeita. pela primeira vez, o artista fica ao lado da Liberdade, com sua vaidade característica, sua aparência negligenciada, sua cartola. E isso sem dúvida constitui uma linha de fronteira para todos os artistas depois dele ${ }^{34}$.

A descrição de Kounellis se refere à sugestão de um autorretrato de Delacroix presente na pintura e materializado no homem com cartola e baioneta. Para Kounellis, quando se representa ao lado da Liberdade, Delacroix afirma um lugar para a arte e para o $\operatorname{artista}^{(\mathrm{v})}$. Esse posicionamento de Delacroix foi reiterado por Kounellis em "Eu nunca matei ninguém, mas estou disposto a fazê-lo".
32 Sem título, 1988. Copos com grapa e formas fundidas em chumbo. Foto: Claudio Abate.

33 Vista da exposição Kounellis, Galeria

Sonnabend, Nova York, 1980. Foto: Harry Shunk.

\section{Embarcações}

A história da humanidade junto ao mar é vasta e contém poderosos capítulos como a Odisseia e as grandes navegações dos séculos XV e XVI. As obras de Kounellis com referências náuticas se estabeleceram entre a potência da imagem mitológica e a contínua atividade comercial realizada por rotas marítimas. A partir de meados da década de 1970, Kounellis, em diversos momentos, se aproximou do universo náutico ao usar modelos de embarcação e fragmentos de barcos - âncoras, mastros, proas, popas, velas etc. -, em suas obras (ver imagens 28, 29, 30, 126 e 165). No final dos anos 1960, o artista já havia utilizado imagens de embarcações em peças gráficas para a divulgação de suas exposições (ver imagem 164). Em 1975, Kounellis expôs, no interior de um navio, uma balança ${ }^{(v)}$ com café $^{(v)}$ (ver imagem 31) e, em 1994, essa experiência expositiva foi ampliada pela exposição individual apresentada no porto do Pireu, em Atenas, dentro do cargueiro Ionion (ver imagens 25, 114, 115,190 e 191) [ver fragmento $\left.{ }^{(v)}\right]$. 


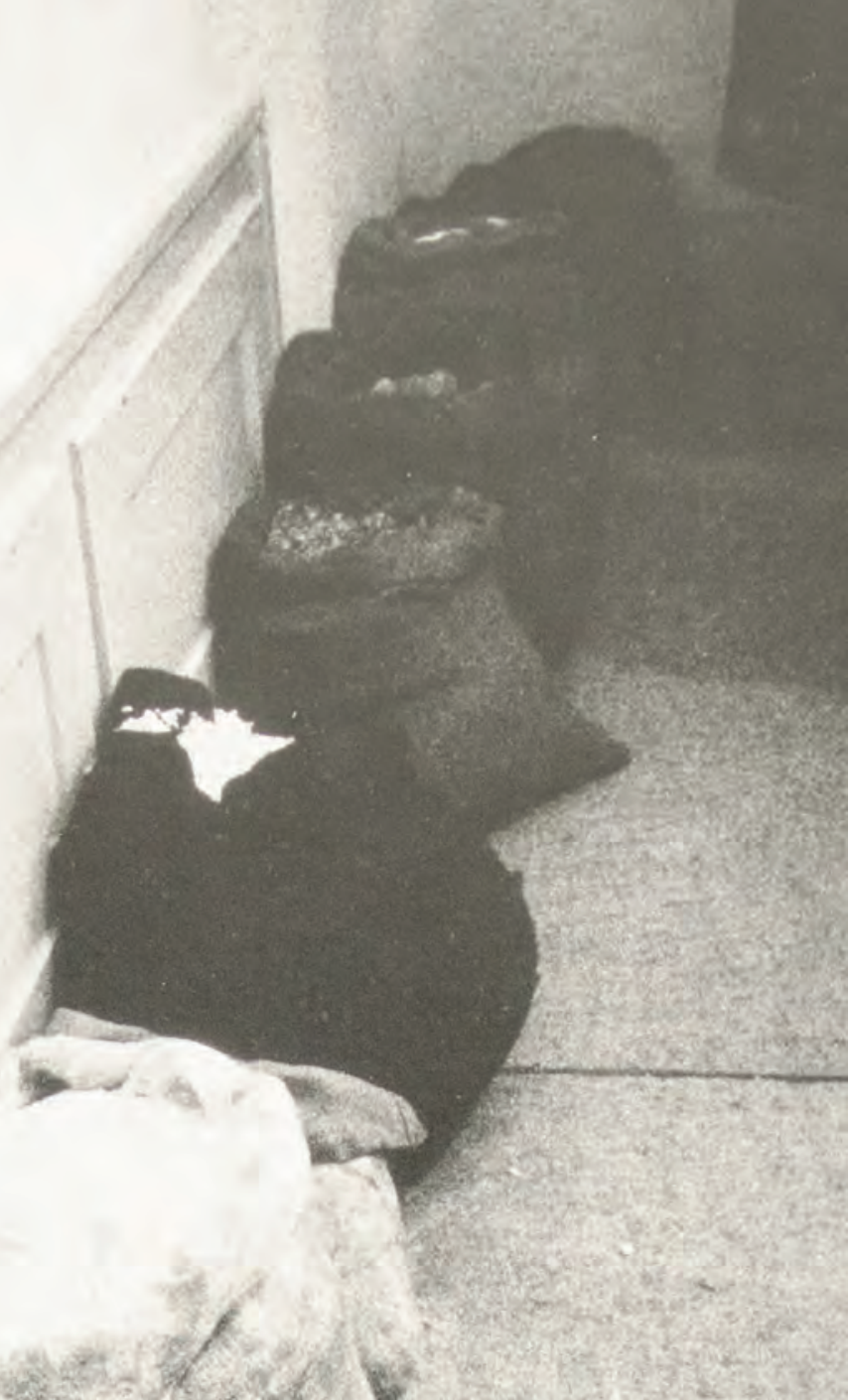

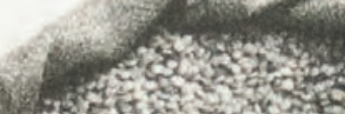

$x^{3}$

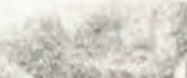

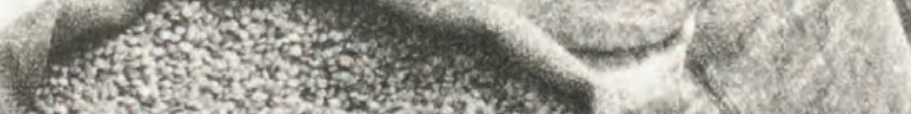

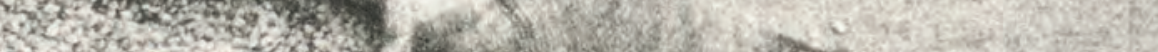

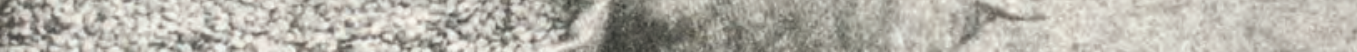

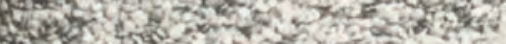
th

1.

1.4

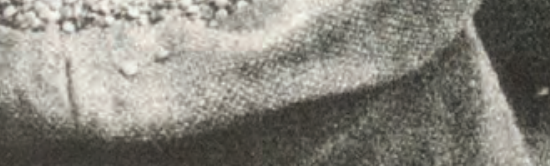

19.

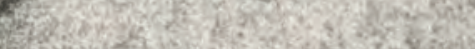
(3) 3. H.

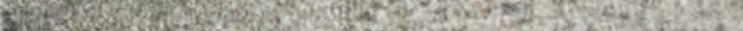

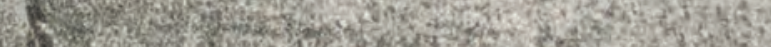
A W

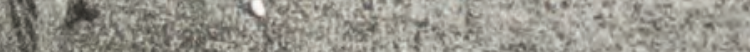

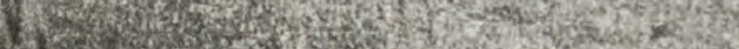
W

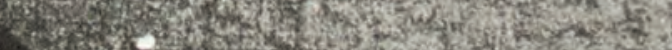

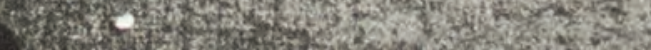
ant

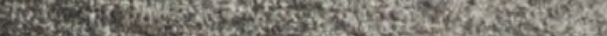

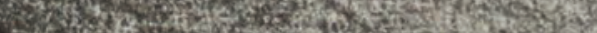

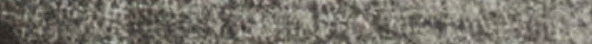
nos

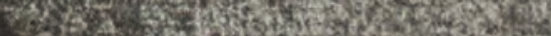

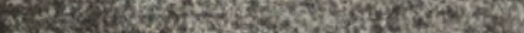




\section{Escala}

A escala na obra de Kounellis foi definida e calibrada no final dos anos 1960 e no decorrer da década seguinte, e se articula em torno das duas acepções do conceito de humanismo ${ }^{(v)}$. O primeiro significado diz respeito à cultura humanística italiana do século XIV que, posteriormente, se difundiu pela Europa, tornando-se o substrato da cultura moderna. A utilização das medidas do papel Fabriano ${ }^{(v)}$ nas chapas de ferro $^{(v)}$ evoca a indústria papeleira da cidade de Fabriano que, assim como outras cidades europeias vinculadas à fabricação do papel, abasteceu as prensas de tipos móveis, invenção de Gutenberg, que materializaram em livros os textos clássicos que fermentaram os debates e as produções intelectuais e artísticas da época. Além, é claro, do uso histórico do papel na produção de desenhos e gravuras. Aliás, as estampas, assim como os livros, atuam de forma decisiva nessa época, não apenas divulgando os avanços artísticos do momento, mas servindo também para a consolidação do modelo de representação linear, dado que de parte significativa dos gravadores do período era esperada a transmissão, por meios gráficos, daquilo que era essencial da imagem pictórica ${ }^{35}$. Ou seja, a gravura de tradução reiterou por meio do desenho a linearidade enquanto substrato fundamental da pintura e, consequentemente, da produção artística da época.

Já a outra acepção do termo que se refere ao homem como "medida das coisas" é percebida nos objetos que foram escolhidos por Kounellis para compor suas obras como cadeira ${ }^{(v)}$, mesa $^{(v)}$, cama $^{(v)}$ e peças de vestuário $^{(v)}$. Esses objetos evocam indiretamente a presença do humano, dado que são projetados em função da escala do corpo. No decorrer da década de 1980, Kounellis transpôs para painéis de metal as dimensões de uma cama de solteiro, $200 \times 90 \mathrm{~cm}$, e ao juntar duas chapas de ferro com essas medidas adicionou ao seu repertório as dimensões de uma cama de casal, $200 \times 180 \mathrm{~cm}$.

Todos os objetos e formas que se referem à escala humana, na obra de Kounellis, articulam, total ou parcialmente, o conceito de estrutura ${ }^{(v)}$. Esse conceito, por sua vez, delineia o perímetro $^{(v)}$ no qual ocorre a apresentação $^{(v)}$ da sensibilidade ${ }^{(v)}$. Em outras palavras, a estrutura oferece a sensibilidade ao contexto que a circunscreve tanto em relação à escala do corpo quanto à cultura.
34 Sem título, 1969. Sacos de juta, grãos, leguminosas e café. $47 \times 137 \times 63 \mathrm{~cm}$. Foto: Claudio Abate. 


\section{Espaço expositivo}

Kounellis durante toda sua trajetória artística demonstrou interesse pelo espaço expositivo, relacionando-o a conceitos fundamentais de sua poética, como cavidade teatral ${ }^{(v)}$ perímetro $^{(v)}$ e estrutura ${ }^{(v)}$. Em suas primeiras pinturas, realizadas entre 1956 e 1966, Kounellis transpunha para o espaço expositivo as dimensões de seu ateliê, uma vez que o artista pintava sobre telas esticadas na parede, o que, segundo ele, impregnava as pinturas com a escala ${ }^{(v)}$ do ambiente de trabalho. As imagens pintadas, em sua grande maioria, correspondiam a signos gráficos e palavras que remetiam a pichações e placas comerciais (ver imagens 7, 8, 48 e 129). Tanto na pichação quanto nas placas comerciais o anonimato do autor está presente. $\mathrm{O}$ reconhecimento de quem as concebeu se dá pela visualização de similaridades entre os demais trabalhos gráficos do gênero espalhados pela cidade, e não por uma declaração direta de autoria, dado que o mais importante para esse tipo de comunicação visual é a transmissão da informação, seja ela codificada para determinados grupos seja aberta a todos, e não a autoria de quem os fez. Por apresentarem em sua superfície esse tipo de signo gráfico que evoca o espaço urbano, essas obras estabelecem um imbricado jogo entre privado e público que suscita a questão sobre a dimensão pública do espaço expositivo.

Gradativamente, entre 1969 e a década de 1990, Kounellis adicionou ao seu processo de trabalho o procedimento do uso do espaço expositivo como "molde", inserindo no lugar de exposição uma dimensão produtiva. Se as pinturas iniciais de Kounellis guardam a escala do ateliê do artista, os trabalhos construídos no espaço expositivo incorporam a escala do lugar de apresentação ${ }^{(v)}$. Logo, ao exibir essas peças em outras exposições, Kounellis expõe e sobrepõe as dimensões de um espaço sobre outro, produzindo, conceitualmente, aquilo que definiu como acumulação ${ }^{(v)}$ (ver e comparar imagens na sequência 142, 148, 150, 105, 112 e 124). Em geral, as obras realizadas que têm o espaço expositivo como gabarito são feitas com matérias-primas que aludem à história ou ao contexto do lugar de exibição, ou seja, elas não carregam em si apenas sua escala, mas também se referem à "memória" de uso espaço.

\section{Esquife}

Esquife se refere tanto a caixão quanto a pequeno barco, o que ecoa nas obras realizadas por Kounellis em navios e com fragmentos
35 Sem título, 1997. Ferro,

armários e chumbo.

$435 \times 1600 \times 75 \mathrm{~cm}$. Foto:

Aurelio Amendola.

36 Vista da exposição fannis Kounellis. Neue National Galerie, Berlim, 2007.

Foto: Manolis Baboussis. 

de embarcações ${ }^{(v)}$. O esquife enquanto barco espelha a ideia de viagem $^{(v)}$ presente em textos como "Hydra", "Dodecafonia" e em obras conduzidas por essa ideia, tal como Louisiana, feita em 1976 em um quarto do Hotel della Lunetta, em Roma (ver imagens 139 e 140). Nessa obra após realizar um corte horizontal na parede - uma alusão à pintura de Lucio Fontana ${ }^{(v)}$-, Kounellis inseriu uma bola de ping-pong para evidenciar a fenda, criando um ponto único dentro do padrão repetitivo do papel de parede, um ponto de referência, o que conceitualmente convertia a cama $^{(v)}$ presente no quarto num esquife cuja navegação seria orientada por esse inusitado "astro celeste".

A escala ${ }^{(v)}$ humana presente na cama e em obras feitas a partir das dimensões desse mobiliário também revela o esquife como correlato ao caixão, sendo essa interpretação mais nítida em algumas peças realizadas nas décadas de 2000 e 2010 (Ver imagens 38, 39 e 125).

\section{Estrutura}

Estrutura é um conceito-chave na poética de Kounellis, elaborado pelo artista em 1967 e desenvolvido junto à ideia de sensibilidade ${ }^{(v)}$. A estrutura delimita fisicamente o perímetro ${ }^{(v)}$ onde a sensibilidade está contida e, conceitualmente, circunscreve-a num determinado contexto. A estrutura é facilmente reconhecida em obras como Sem título (Papagaio) ou Sem título (Algodão), ambas de 1967. Nessas peças, a estrutura é um suporte de ferro ${ }^{(v)}$ que apresenta um papagaio e um volume de algodão, respectivamente (ver imagens 51 e 22). No entanto, a fisicalidade da estrutura não se limita ao ferro. Saco de juta ${ }^{(v)}$, cadeira $^{(v)}$, porta ${ }^{(v)}$, janela ${ }^{(v)}$ e o próprio espaço expositivo $^{(v)}$ materializam esse conceito, pois esses objetos também foram escolhidos por Kounellis para conter e/ou delimitar objetos, materiais e seres vivos que articulam o conceito de sensibilidade.

Em geral, as medidas correspondentes à estrutura são as dimensões da cama ${ }^{(v)}$, do papel Fabriano ${ }^{(v)}$ e de partes do espaço arquitetônico. Essas medidas, por sua escala ${ }^{(v)}$, estabelecem como parâmetro para a sensibilidade as duas acepções do conceito de humanismo ${ }^{(v)}$.

\section{Fabriano}

Fabriano é o nome de uma marca de papéis italiana usada pelo métier da arte como suporte para pinturas e desenhos, e cuja fábrica se localiza na
37 Sem titulo, 1999.

Fotografia de Kounellis carregando um grande saco. Imagem usada como convite da exposição fannis Kounellis, Igreja de Santo Agostinho - UNAM, Cidade do México, 1999. Foto: Magdalena Martinez Franco. 

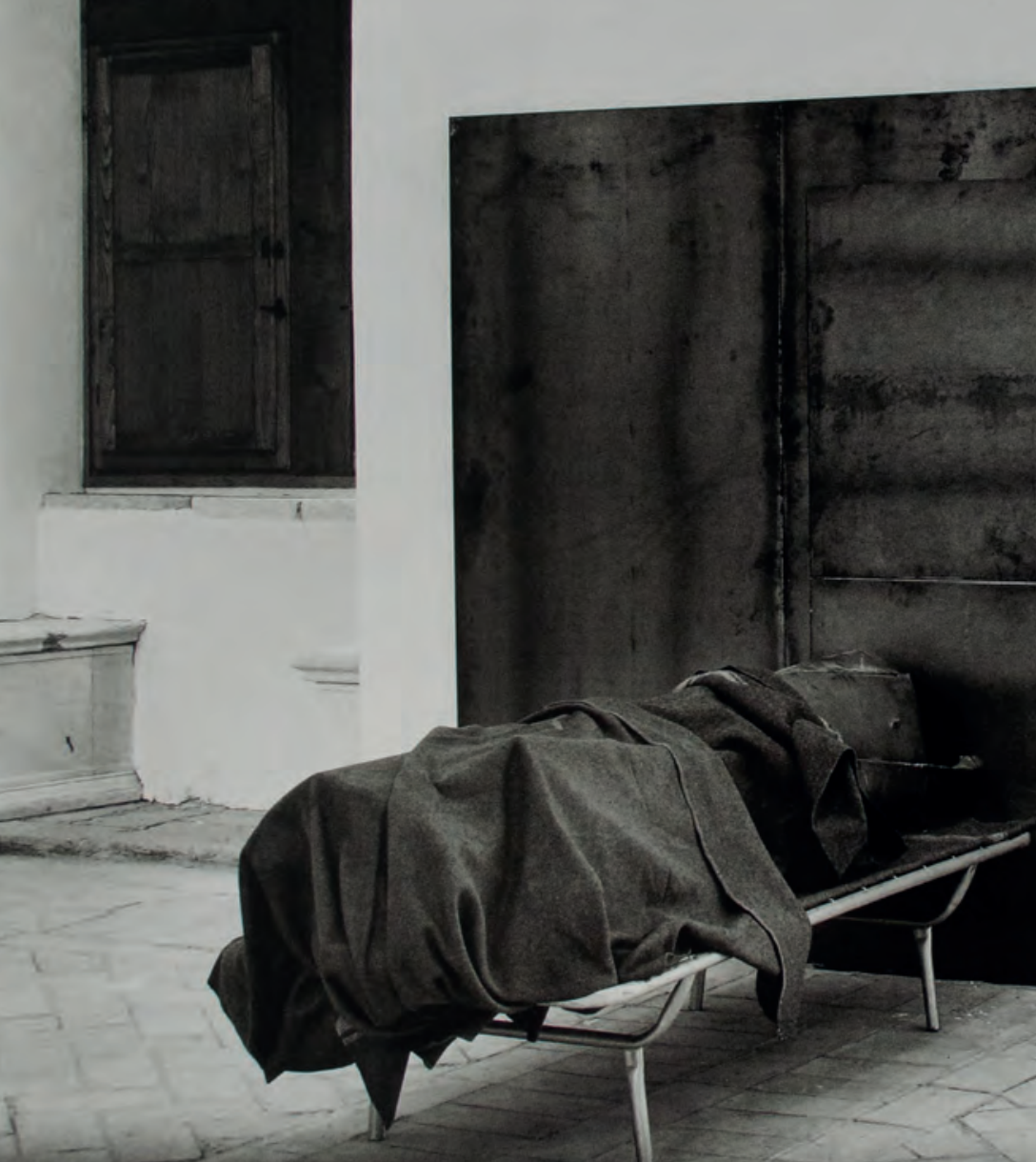

11111
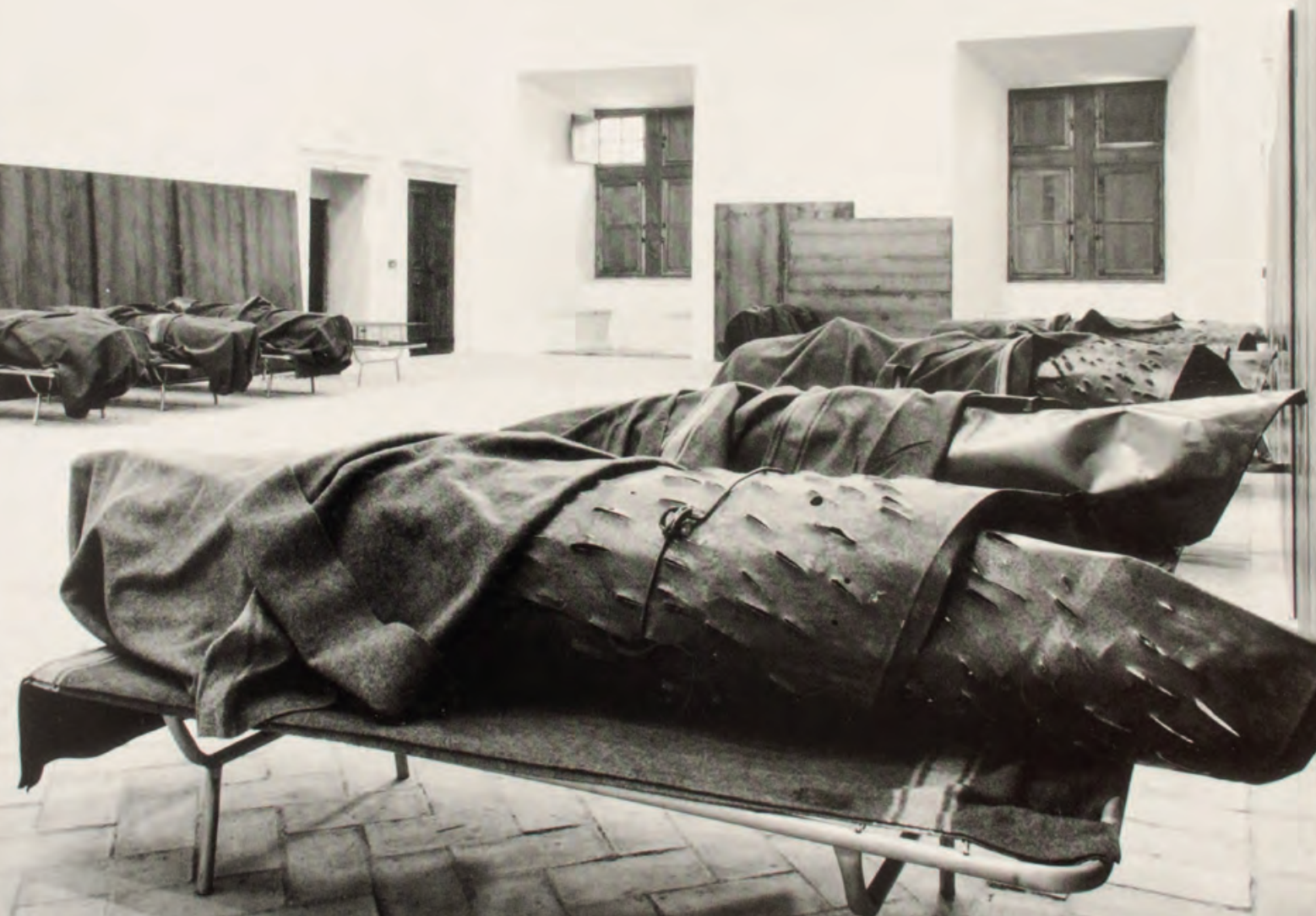

325: $\checkmark$ 
cidade de Fabriano, na Itália. Kounellis, em 1967, para de usar o papel e a tela como suportes exclusivos para trabalhos "bidimensionais" e passa a utilizar também painéis de metal para esse tipo de produção. No entanto, Kounellis transfere para essas chapas de ferro ${ }^{(v)}$ as medidas da folha de papel Fabriano $(100 \times 70 \mathrm{~cm})$, transpondo a referência do suporte do desenho e da pintura para essa estrutura ${ }^{(v)}$ (ver imagens 15, $44,51,83,109$ e 184).

Além da associação do papel Fabriano ao universo das artes visuais, cabe lembrar que a indústria de papel em Fabriano, no começo do século XIV, está intimamente associada à história da indústria livreira ${ }^{36}$, que se desenvolveu em torno da invenção da prensa de tipos móveis de Gutenberg. O livro(v) ${ }^{(v)}$ como tecnologia de leitura e distribuição de textos foi um dos principais responsáveis pela divulgação da cultura humanista por toda a Europa, entre os séculos XV e XVII. Por conta disso, acredito que a escolha de Kounellis pelas medidas do papel Fabriano alude tanto aos materiais tradicionais da arte quanto à história do livro e, consequentemente, do humanismo ${ }^{(v)}$.

\section{Faca}

A faca é um objeto que traz em si a ideia de corte e agressão, e em geral aparece em contraponto a objetos delicados, como peças de vestuário $^{(\mathrm{v})}$ ou seres frágeis como o peixe ${ }^{(\mathrm{v})}$. Em algumas exposições, Kounellis utilizou facas para construir obras que remetiam à forma de uma cortina ${ }^{(v)}$ (ver imagem 80 ). Nesses trabalhos, sons metálicos eram criados pelo deslocamento de ar produzido pelo observador ao se aproximar da peça.

\section{Ferro}

Dentro da poética de Kounellis, o ferro foi utilizado essencialmente em termos simbólicos e como suporte. Enquanto suporte, o ferro está intimamente ligado ao conceito de estrutura ${ }^{(v)}$; já simbolicamente, o ferro se relaciona diretamente à produção industrial e, por consequência, remete à Revolução Industrial e a seus desdobramentos históricos, que alteraram substancialmente a dinâmica social a partir do século XVIII.
38 Detalhe de Sem título,

2000. Camas de metal,

cobertores, chapas metálicas enroladas e painéis de ferro. Castelo Colonna, Genazzano, 2000. Foto:

Manolis Baboussis.

39 Sem título, 2000. Camas de metal, cobertores, chapas metálicas enroladas, painéis de ferro. Castelo Colonna, Genazzano, 2000. Foto: Manolis Baboussis. 


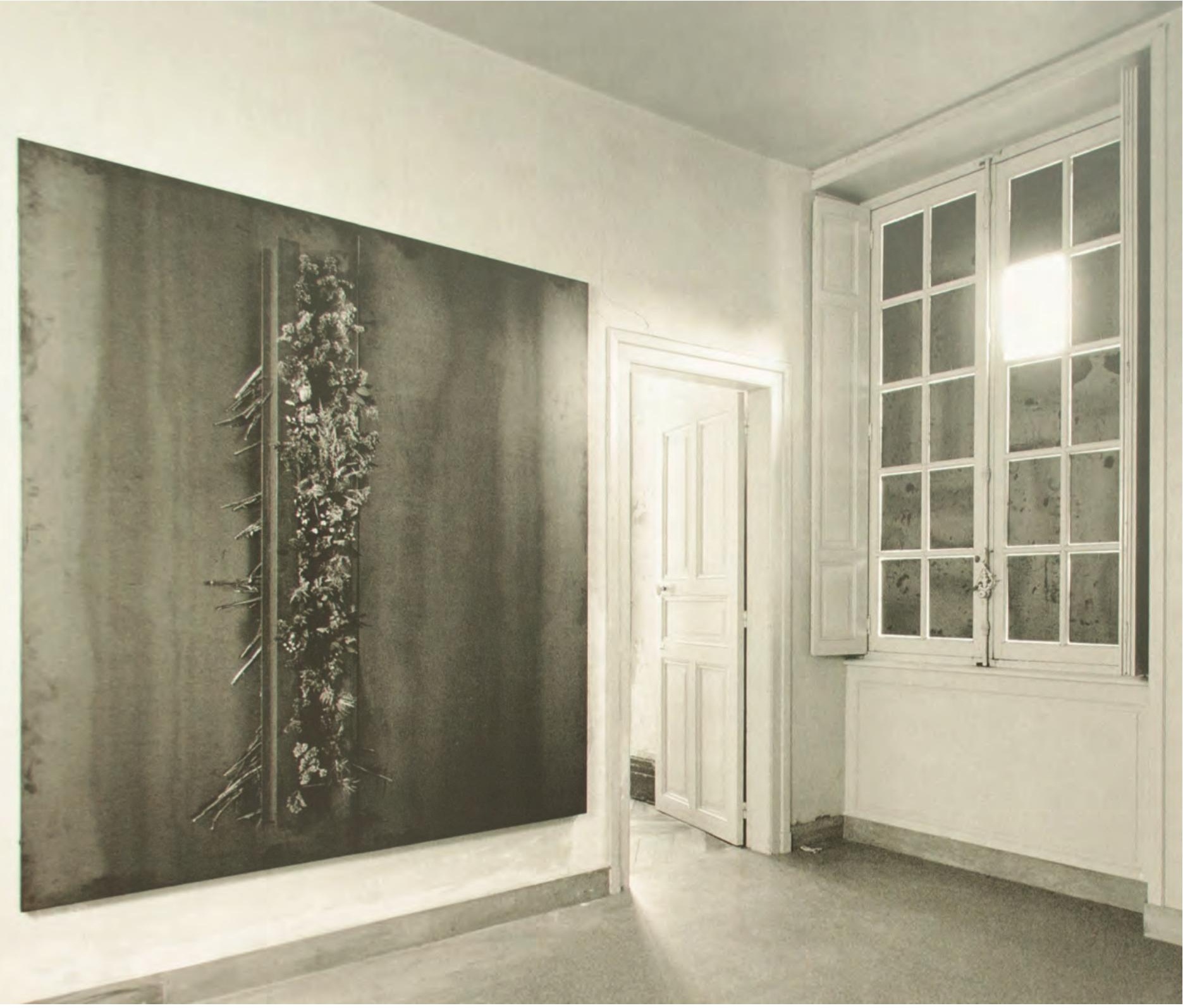




\section{Flores}

Em meados da década de 1960, Kounellis produziu uma série de pinturas em que a silhueta de uma rosa era pintada com tinta branca ou preta sobre um fundo branco. $\mathrm{O}$ artista também recortou e fixou sobre a tela essas silhuetas de rosa (ver imagens 41 e 42). Sobre essas obras, Kounellis conjecturava que a retirada das informações que ofereceriam ao observador uma apreensão realística da imagem $^{(v)}$ abriria espaço para a imaginação:

$\mathrm{Na}$ vida real, as rosas nunca são negras. Se você usa verde para uma folha, o verde é uma cor naturalista, mas se você usa a cor do alumínio muda automaticamente a ordem, não é? Não quero dar ao espectador um objeto ready-made, mas fazê-lo trabalhar com sua imaginação ${ }^{37}$.

Posteriormente, em Sem título, de 1967 (ver imagem 43), a experiência com a forma da flor foi transferida da tela para uma chapa de ferro ${ }^{(v)}$ e associada a um maçarico, negando qualquer ordem naturalista e alterando substancialmente as relações entre forma, material e referente.

A partir dos anos 1980, Kounellis utilizou flores colhidas e organizadas em ramalhetes em suas obras (ver imagem 40), articulando o conceito de sensibilidade ${ }^{(v)}$. A apresentação ${ }^{(v)}$ dessas flores indica, no decorrer do período expositivo, o tempo da vida e da natureza ao se esvaírem gradativamente.

\section{Fragmento}

A ideia de fragmento aparece em dois níveis da obra de Kounellis: como matéria bruta e como procedimento de trabalho. No que diz respeito à matéria bruta ou, em outras palavras, aos materiais primários eleitos pelo artista para a elaboração de um trabalho, Kounellis frequentemente usou fragmentos de: estátuas, frisos, colunas, capitéis, aparelhos de jantar, vigas, móveis e embarcações ${ }^{(v)}$ (ver imagens 28, 29, 35, 105, 126 e 193). Pela lista elencada, nota-se que esse conjunto de materiais evoca as imagens da ruína e do naufrágio, ambas recorrentes nos textos do artista e evocadas em associação às guerras que ocorreram no território europeu.

Porém, ao tratar do tema da ruína ou do naufrágio, Kounellis não se fixa numa melancolia pela perda, mas reconhece na imagem ${ }^{(v)}$

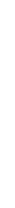



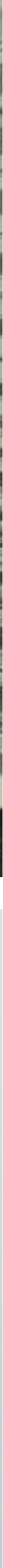
da destruição uma afinidade com procedimento da colagem na arte moderna, vide "Eu estava procurando a cabeça de Safo" e "Homem da antiguidade, um artista moderno". Kounellis não traz esses fragmentos de ruínas e naufrágios por um esforço arqueológico, mas por um impulso de criação. Ou seja, o que está em jogo ao usar esses fragmentos não é a construção de um museu ou de um inventário do passado, mas a combinação de elementos para a criação de uma nova linguagem ${ }^{(v)}$ como um modo de recuperação das ideias e histórias contidas nesses fragmentos, conforme intuímos ao ler "Eu nunca matei ninguém, mas estou disposto a fazê-lo".

Nesse sentido, a organização dos fragmentos é crucial. Grosso modo, identifico ao menos três modelos de ordenamento usados por Kounellis: a parede $^{(v)}$, a partitura ${ }^{(v)}$ e a prateleira ${ }^{(v)}$. Conformados enquanto parede, os fragmentos são usados para obstruir portas e janelas, evidenciando o perímetro ${ }^{(v)}$ dessas e, consequentemente, revelando a escala ${ }^{(v)}$ humana ali presente (ver imagens 105 e 188). Como partitura, os fragmentos são distribuídos no espaço ou fixados em painéis de ferro $^{(\mathrm{v})}$ de forma rítmica, criando uma composição visual que se assemelha a uma partitura (ver imagens 64, 65 e 88). Vale lembrar que, na década de 1970, Kounellis usou fragmentos de peças e óperas eruditas em performances com música ${ }^{(v)}$. Por fim, dispostos em prateleiras ou pedestais, individualmente ou em grupos, os fragmentos parecem representar letras, sílabas ou palavras de um sistema de escrita não verbal (ver imagens 26 e 27).

\section{Fogo}

O fogo não é apenas calor, mas também uma fonte de luz. A lâmpada de óleo que iluminava a cena de Guernica, ou a vela que iluminava o rosto da mulher perto da mesa na pintura de La Tour, criava sombras, volumes marcados e, com alguns toques aqui e ali, determinava a imagem.

A primeira vez que usei um maçarico foi em 1967, para marcar o centro de uma escultura, uma margarida metálica, de modo a acentuá-lo. Então, em 1969, na Galeria Iolas em Paris, coloquei maçaricos ao longo da parede, em uma linha horizontal, ao nível dos olhos, para indicar o perímetro da galeria.

O fogo, para mim, é equivalente ao papagaio em 1967. É vivo, gira-se agressivamente em direção ao exterior. Mas nenhum deles, nem o fogo nem o papagaio, teria sentido sem o suporte de ferro. Eles são vivos, reais, mas
41 Sem título, 1967.

Tela sobre tela, alfinetes

de segurança e gaiolas

com pássaros vivos.

$280 \times 300 \mathrm{~cm}$. Foto:

Claudio Abate.

42 Sem título, 1965 -

1966. Tecido sobre tela.

$210 \times 210 \mathrm{~cm}$. Foto:

Claudio Abate. 

acima de tudo são signos de uma imagem construída a partir de relações. E, em meu entendimento de longo prazo, ambos são pinturas para mim. Me perguntam se eu sou um pintor realista, e a resposta é não. O realismo representa enquanto eu apresento ${ }^{38}$.

O fogo aparece pela primeira vez na obra de Kounellis em Sem título, de 1967, peça na qual um maçarico é fixado em uma estrutura ${ }^{(v)}$ metálica cuja forma remete a uma flor (ver imagem 43). Posteriormente, o fogo aparece associado a outras estruturas de ferro(v) e a objetos como instrumentos musicais $^{(\mathrm{v})}$. Além do maçarico, velas, lâmpadas a óleo e combustível sólido foram utilizados pelo artista para produzir e manter pontos de chama.

A diferença entre os tempos de queima, a intensidade das labaredas e o resultado da combustão realizada em maçaricos, velas, lâmpadas a óleo ou combustíveis sólido evocam distintas referências históricas e artísticas que, por sua vez, articulam o fogo como fonte luminosa, símbolo de vigília e elemento de purificação e regeneração.

Entre os objetos usados por Kounellis para inserir o fogo em suas obras, gostaria de destacar o maçarico, pois, além da chama, produz forte ruído, criado pela combustão do gás, e, em determinadas situações de exposição, antecipa a audição em detrimento da visão na percepção da peça.

Fontana, Lucio (1899-1968)

Escultor e pintor ítalo-argentino. Fontana desenvolveu sua pesquisa plástica por meio da experimentação de diferentes técnicas de perfuração e corte da superfície da escultura e da pintura $^{(v)}$, o que denominou como concetto spaziale. Esse termo, segundo Fontana, se refere a uma nova dimensão espacial criada na superfície das obras através das aberturas feitas. Embora o ato de cortar ou perfurar a tela indique uma ação de violência e, aparentemente, de destruição, Fontana argumentava que se tratava de um gesto de abertura da superfície pictórica para o espaço pluridimensional.

A obra de Fontana, por seus procedimentos de trabalho, que adicionam à linguagem $^{(v)}$ da arte uma nova concepção de pintura, foi uma das principais referências dos artistas vinculados à Arte Povera ${ }^{(v)}$. Kounellis em "Burri e Fontana" afirma a importância da obra do artista
43 Sem título, 1967. Chapa de ferro e maçarico. $150 \mathrm{~cm}$ (diâmetro). Foto: Claudio Abate. 


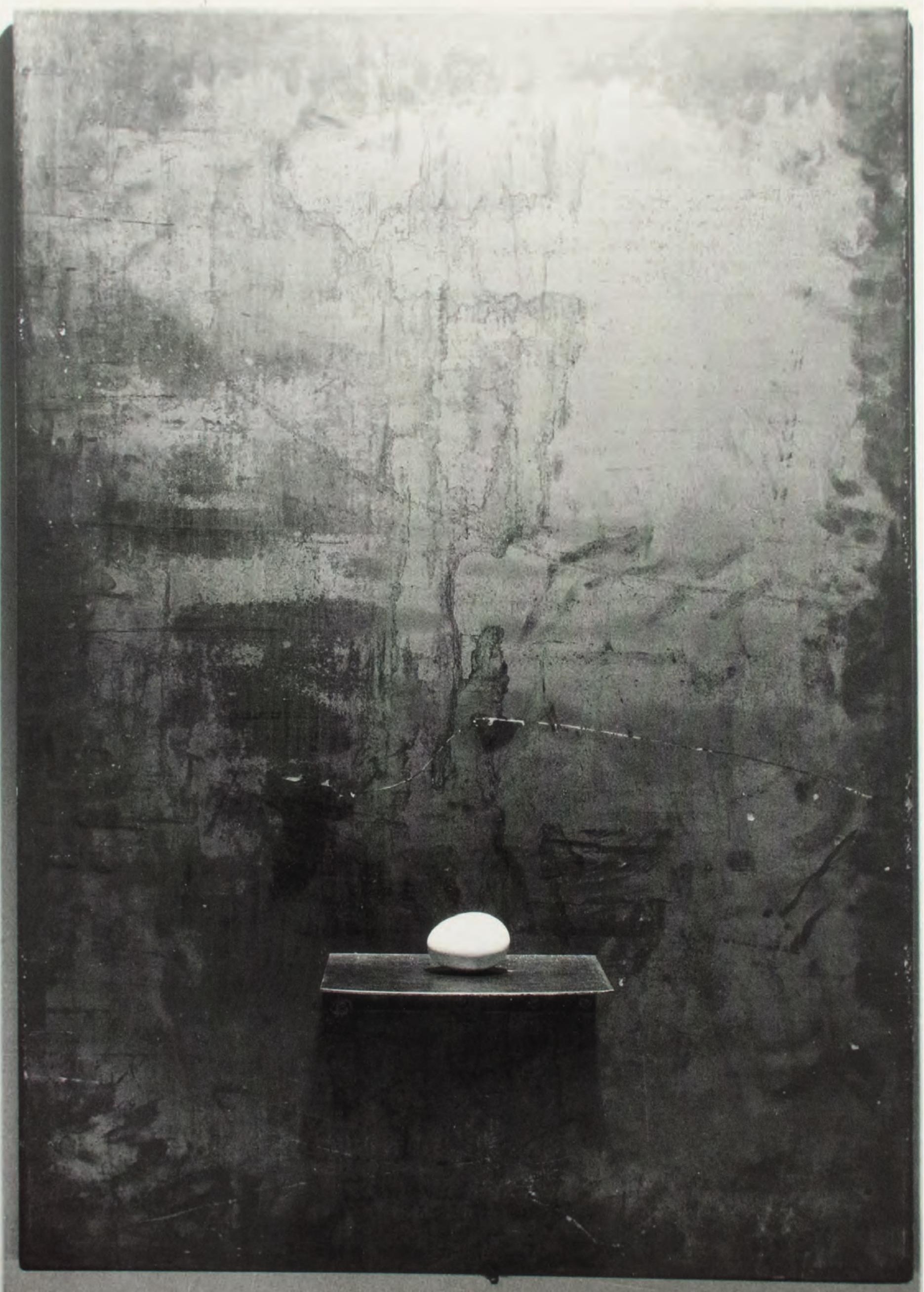


em sua formação, bem como, em entrevista a Wim Beeren ${ }^{39}$, associou os cortes realizados por Fontana à figura de São Tomé que investiga com as mãos as chagas de Cristo na pintura $A$ incredulidade de São Tomé, de Caravaggio $^{(\mathrm{v})}$.

\section{Fumaça}

A fumaça contém uma ideia de sombra e uma ideia de pintura, de jeito nenhum isso lembra uma ideia de morte, é sobre observar as diferentes figuras que a fumaça pode criar sugerindo imagens fantasmagóricas, um fantasma. E o fantasma relembra o passado. E o passado como pintura que volta ${ }^{40}$.

A citação de Kounellis se refere às manchas de fumaça presentes na obra Sem título, de 1984-87 (ver imagem 73). Ao observamos atentamente a peça em questão nos deparamos com várias referências à pintura ${ }^{(v)}$, como o quadrado $^{(\mathrm{v})}$ preto de Kazimir Malevich ${ }^{(\mathrm{v})}$ e a assemblage com pedaços de madeira de Kurt Schwitters ${ }^{(v)}$, por exemplo. Cada uma dessas referências corresponde a diferentes concepções de pintura que, somadas, estabelecem a linguagem ${ }^{(\mathrm{v})}$ pictórica de Kounellis.

Nesse contexto, a fumaça apresenta uma ideia de pintura cuja procedência remete também à ideia de sombra que Kounellis associou repetidas vezes a Caravaggio(v) ${ }^{(v)}$ Logo, podemos supor que a fumaça, ao materializar aparições fantasmagóricas, se refere às figuras de Caravaggio que emergem do fundo negro de suas pinturas.

Contudo, a partir da leitura de "Pedra de fumaça", de 1993, conjecturo outra hipótese para a ideia de pintura presente na fumaça. Nesse texto, Kounellis revela que a técnica usada no processo de criação da série de litogravuras intitulada Pedra de fumaça se baseia em desenhos casuais feitos à mão, ao retirar a fuligem acumulada em uma janela ${ }^{(v)}$, associando a técnica escolhida à imagem $^{(\mathrm{v})}$ final das estampas que, segundo o artista, eram "rostos fantasmáticos".

Ao observamos essas litogravuras notamos uma plasticidade expressionista que aproxima os rostos produzidos por Kounellis de algumas figuras pintadas por James Ensor, Edvard Munch ${ }^{(v)}$ e Ernst Ludwig Kirchner, artistas que desenvolveram suas obras na virada do século XIX para o XX, lidando com a esperança e o pessimismo da sociedade europeia pós-Revolução Industrial. Nesse caso, a fumaça corresponde a uma ideia da pintura expressionista.
44 Sem titulo, 1969. Chapa de ferro e ovo. $100 \times 70 \mathrm{~cm}$. Foto: Claudio Abate.
39 Ver Kounellis, Codognato e D'Argenzio (2002, p. 250).

40 Depoimento de Jannis Kounellis na Galeria de Arte NSW, em Sidnei, Austrália, durante a instalação da obra Sem título, de 1984-87. Disponível em: https://bit. Iy/2wyK69S. Acesso em: 2 fev. 2020 


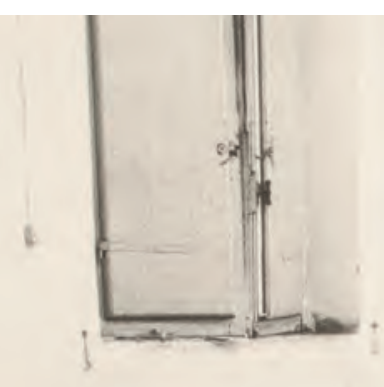

it $-1:-7$

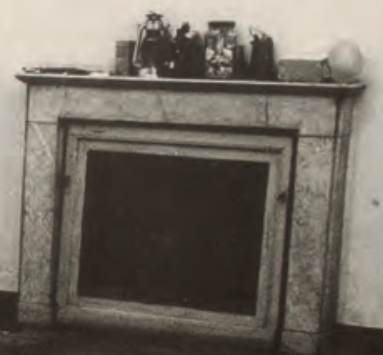

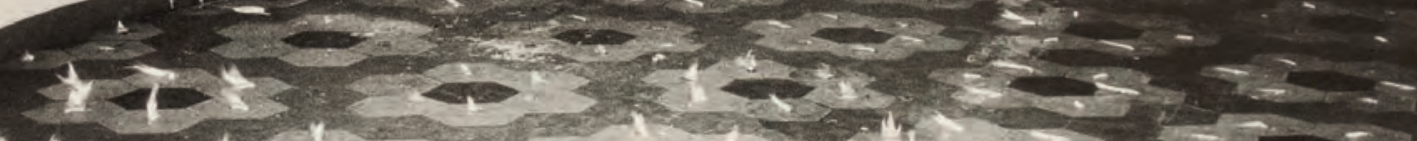

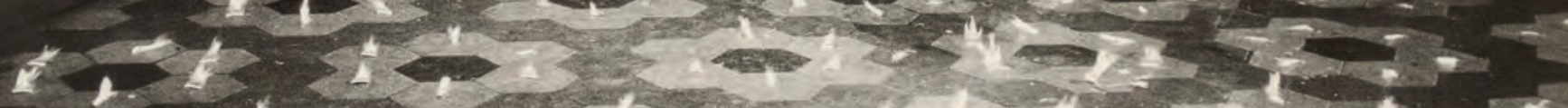

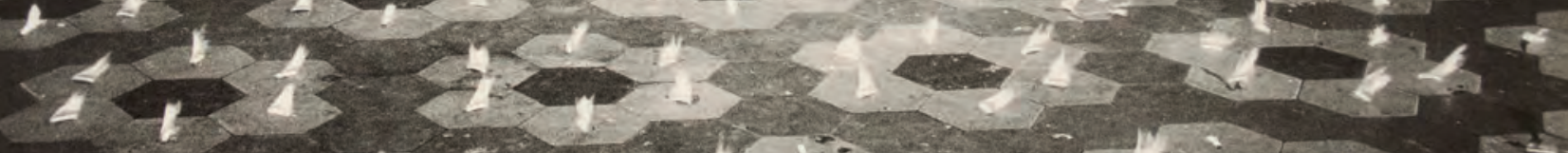
4 
Entretanto, há uma terceira leitura para a fumaça que também abarca a ideia de sombra e fantasma. Essa diz respeito ao mito do surgimento da pintura narrado por Plínio, o Velho, no qual uma jovem desenha na parede $^{(v)}$ o contorno da sombra do amado que irá partir ${ }^{41}$. No mito, a pintura surge através da fixação da projeção de um corpo. O desenho do perímetro $^{(\mathrm{v})}$ da sombra e a ausência do corpo que a projetou estabelecem uma presença fantasmática, o que encontra paralelos com a poética de Kounellis [ver mancha ${ }^{(\mathrm{v})}$ ].

Giacometti, Alberto (1901-1966)

Escultor suíço. Em 1991, Kounellis publicou um elogio a Giacometti e a sua obra ${ }^{42}$. Nesse texto, Kounellis apresenta sua empatia pela escultura Homem andando e afirma que o legado de Giacometti foi a centralidade ${ }^{(v)}$ do homem. Creio que o interesse de Kounellis pelas esculturas de Giacometti se baseia na tensão dramática que elas possuem.

Ao serem dispostas no espaço, seja ele qual for, as esculturas de Giacometti reiteram a dimensão da escala humana presente na arquitetura. Seus pés grandes e ancorados no chão permitem a ascensão vertical da obra, mas também concedem gravidade e peso ${ }^{(v)}$ à ação de caminhar descrita pela escultura, que se converte num "movimento estático", expressão usada por Kounellis. Esses elementos formais conferem ao Homem andando uma força de atração centrípeta, fazendo com que a atenção do observador se desloque do espaço para a peça.

Goya, Francisco de (1746-1828)

Pintor espanhol. Em 1982, Kounellis publica "As pinturas negras", no catálogo da $7^{\text {a }}$ Documenta de Kassel, exposição na qual realiza, em parceria com Carlo Quartucci, o espetáculo Funeral, a partir de uma imagem de Fannis Kounellis (ver imagem 14). Por meio de uma narrativa fragmentada, o texto descreve uma imagem ${ }^{(v)}$ vaga e aberta que sugere a descrição de uma pintura inacabada. Por sua vez, o título do texto evoca as Pinturas negras de Goya, apesar de não mencionar qualquer aspecto dessas obras.

As Pinturas negras são uma série de quatorze pinturas feitas por Goya nas paredes de sua residência, a Quinta del Sordo, e que, posteriormente, foram transladadas para o Museu do Prado, em Madrid.
45 Vista do ateliê de
41 (STOICHITA, 2016, p. 11).

42 (KOUNELLIS, 1991, p. 439). 

Essas obras retratam temas sombrios - míticos e inventados por Goya potencializados pela escuridão das telas. $\mathrm{Na}$ série se destaca a pintura Saturno, que apresenta o deus Saturno devorando um de seus filhos.

Nas Pinturas negras e em outros trabalhos, Goya desenvolveu sua visão sobre o seu tempo histórico. O modo cru e franco com que retratava tanto aquilo que via quanto o que imaginava contribuiu para a fundamentação de uma linguagem ${ }^{(v)}$ pictórica que dissolvia a relação meramente ilustrativa entre a pintura e o texto.

Tendo em vista que o texto escrito por Kounellis acompanhava uma peça teatral cuja imagem central era um cortejo fúnebre e que o artista reconhecia no funeral um conjunto de gestos de identificação cultural, vide "O resultado é o nosso patrimônio formal", suponho que o interesse de Kounellis por Goya residia na capacidade deste de produzir imagens de forte e rápida identificação, sem que, no entanto, tivessem qualquer vínculo com textos míticos, religiosos ou históricos.

\section{Gancho}

O gancho de açougueiro e do roupeiro foi um objeto geralmente usado em contraponto a elementos planos que sugerem a ideia de superfície pictórica, como as chapas de ferro ${ }^{(v)}$, por exemplo. Os ganchos sustentam vários tipos de objetos, como: pedaços de carne ${ }^{(v)}$, peças de vestuário $^{(v)}$, maçarico e instrumentos musicais ${ }^{(v)}$. Essa função traz consigo a ideia de peso ${ }^{(v)}$. O gancho aparece pela primeira vez na exposição realizada na Galeria Iolas, em Paris, de 1969, na qual Kounellis usa esse objeto para pendurar, na altura dos olhos, um conjunto de maçaricos pela extensão do perímetro $^{(v)}$ do espaço $\operatorname{expositivo}^{(\mathrm{v})}$ (ver imagem 20).

\section{Guardião}

Eu sou um conservador. Um guardião. A realidade invisível é apócrifa e seu significado é conhecido pelo seu guarda. Portanto, o guardião preserva um acesso geral aos segredos místicos conservados.

A origem da composição é a custódia e, em termos de composição, conserva a ordem e une o presente e o passado. E o pintor moderno é um homem da antiguidade, como em qualquer outra época ${ }^{43}$.
46 Sem título, 1985. Painel pintado e 24 prateleiras de metal com fuligem. Foto: Claudio Abate.

47 Sem título, 1970. Pianista executa fragmento de "Va, pensiero", coro da ópera Nabuco, de Giuseppe Verdi. Foto: Ugo Mulas.
43 (KOUNELLIS; CODOGNATO; D'ARGENZIO, 2002, p. 103). 

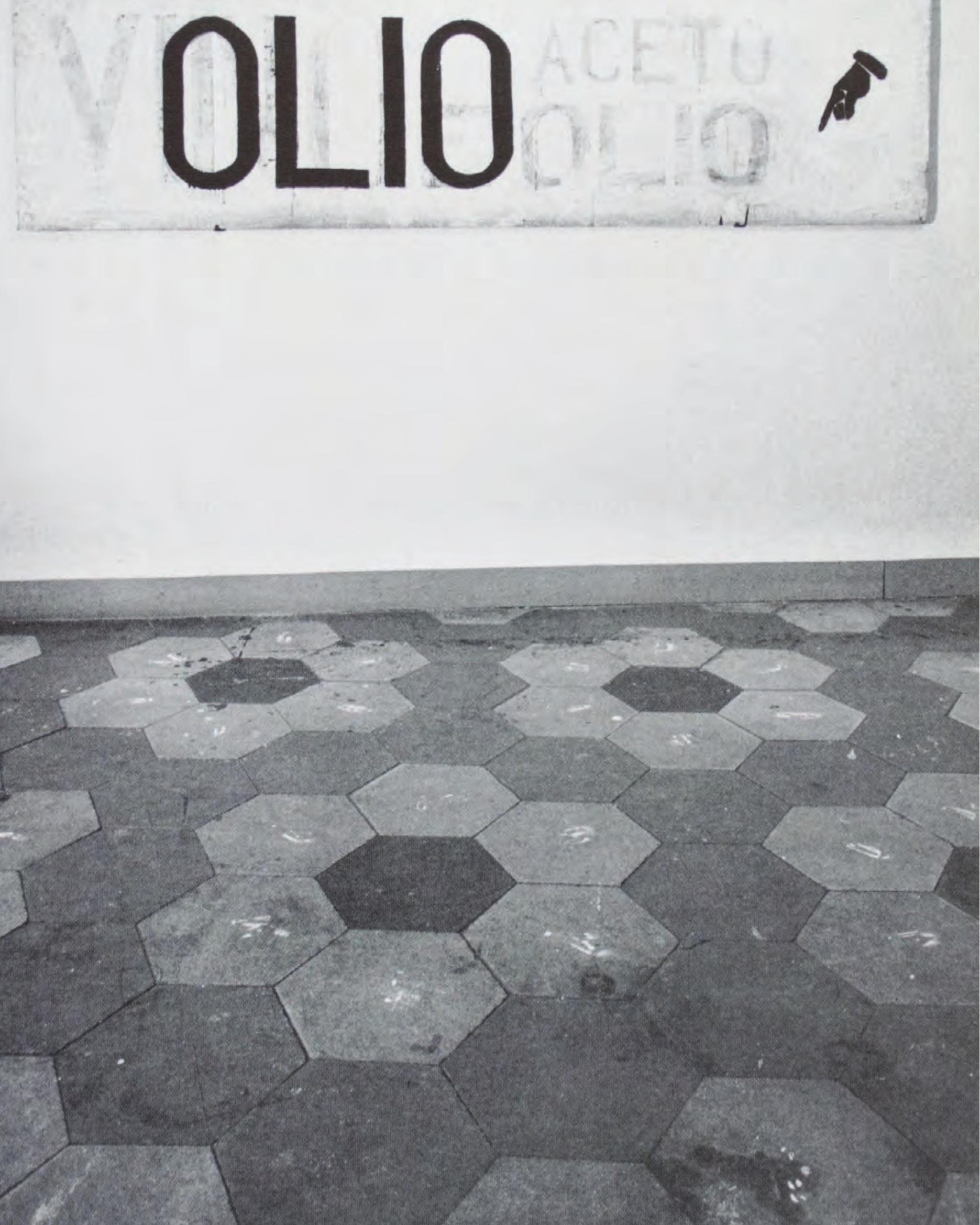
Creio que, ao definir-se como guardião, Kounellis busca reafirmar a relação entre o $\operatorname{artista}^{(v)}$ e a linguagem ${ }^{(v)}$, sendo esta última um imbricamento indissociável entre técnica e teoria. No Renascimento, a sugestão de Leonardo da Vinci de que a "pintura é baseada na teoria, em outras palavras, pode ser demonstrada e, portanto, conta como uma ciência" ${ }^{44}$ foi fundamental para a definição da pintura enquanto arte liberal e, assim, fundamentar uma relação sólida entre as técnicas artísticas e as teorias da representação. Em 2012, Rosalind Krauss, em entrevista a Yve-Alain Bois sobre o livro Under the blue cup (2011), pontua outro aspecto da produção artística relativo ao domínio técnico e teórico e, por consequência, do meio, assinalando a especificidade do conhecimento, leia-se da linguagem, da arte. Para Krauss "o medium é uma via para o artista, pintor, escultor, quem quer que seja, lembrar quem ele ou ela é, nos termos da história nesse medium" ${ }^{\$ 5}$. Por essa afirmativa, vislumbramos o artista como o detentor da linguagem dos meios, e é a posse e a guarda desse saber que o identifica como artista.

No entanto, o conhecimento da arte não é estático, e os artistas enquanto guardiões o protegem, adicionando a ele novos problemas e soluções, de acordo com seus "acentos pessoais" ou, em outras palavras, segundo a lógica de seu tempo.

\section{Grapa}

A grapa é uma água ardente de forte odor extraída do processo de fabricação do vinho. Em 1988, Kounellis encheu centenas de pequenos copos de vidro com grapa e dispôs sobre eles formas cortadas em folhas de chumbo que remetem a desenhos expostos em 1980 (ver imagem 32). Esses desenhos e formas em chumbo, por sua vez, evocam a imagem da pintura $O$ Grito, de Edvard Munch ${ }^{(v)}$. Na obra de Kounellis, o cheiro da grapa "substitui" o "som" do grito pintado por Munch, transformando a sensibilidade sonora em olfativa.

\section{Humanismo}

O termo humanismo

é usado para indicar duas coisas diferentes: I) o movimento literário e filosófico que nasceu na Itália na segunda metade do séc. XIV, difundindo-se para os demais países da Europa e constituindo a origem da cultura moderna;
48 Sem título, 1958. Óleo sobre painel. $60 \times 240 \mathrm{~cm}$. Foto: Claudio Abate.
44 (DAMISCH, 2002, p. 170). 45 (BOIS; NUNES, 2018, p. 38-39). 

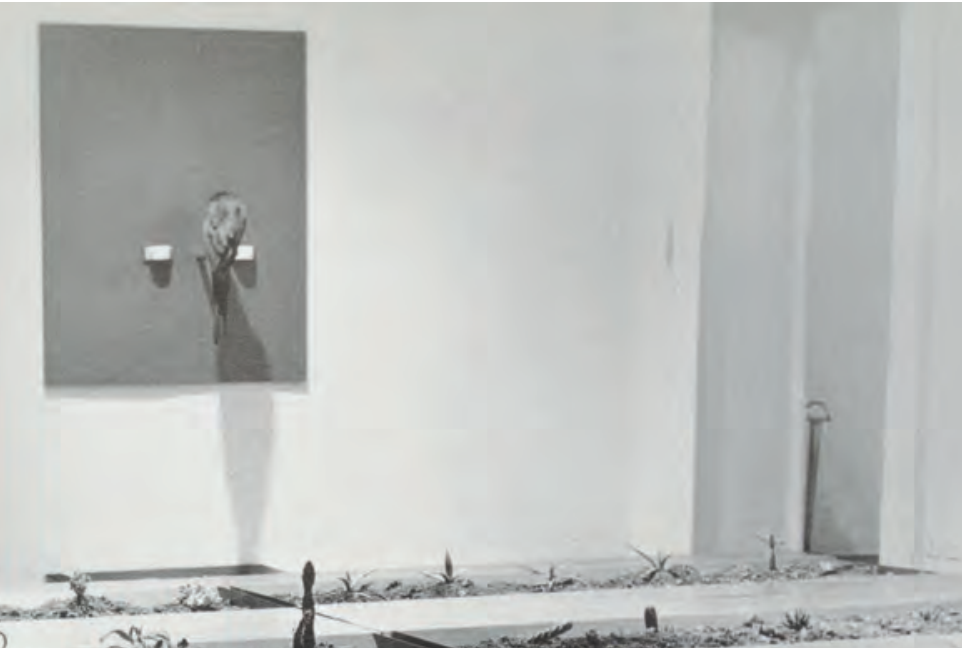

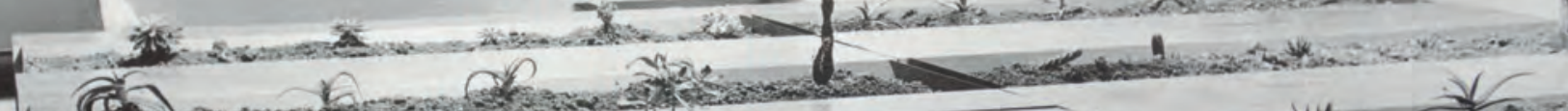
(1)

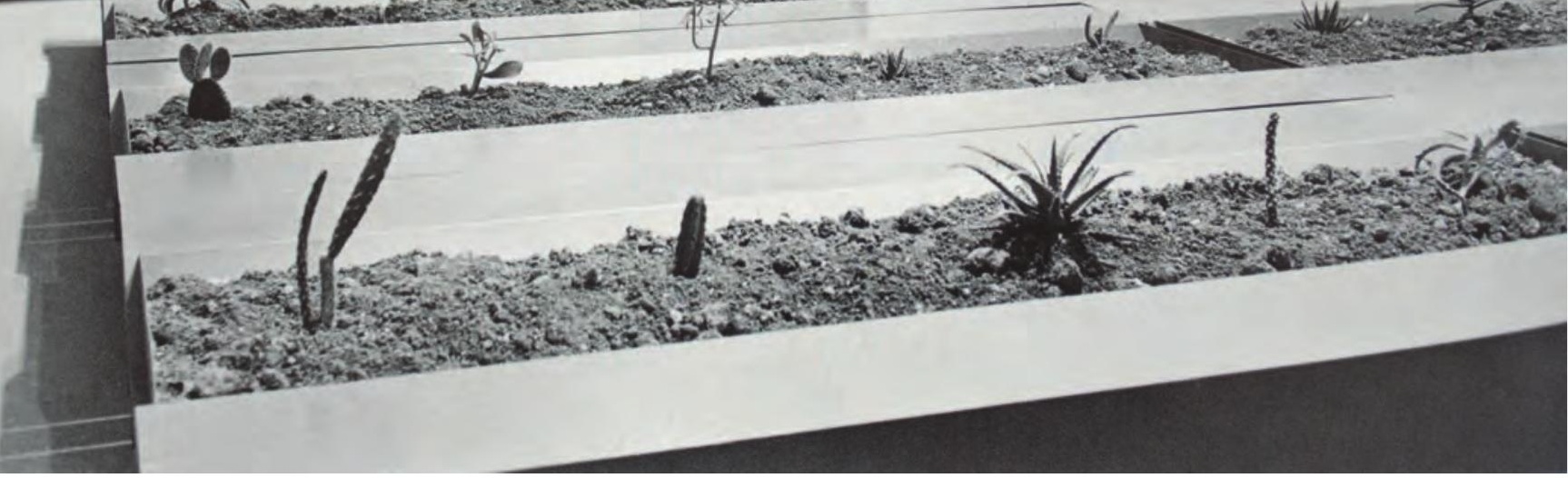


II) qualquer movimento filosófico que tome como fundamento a natureza humana ou os limites e interesses do homem. I) Em seu primeiro significado, que é o histórico, o Humanismo é um aspecto fundamental do Renascimento, mais precisamente o aspecto em virtude do qual o Renascimento é o reconhecimento do valor do homem em sua totalidade e a tentativa de compreendê-lo em seu mundo, que é o da natureza e da história. [...] II) O segundo significado dessa palavra nem sempre tem estreitas conexões com o primeiro. Pode-se dizer que, com esse sentido, o Humanismo é toda a filosofia que tome o homem como 'medida das coisas', segundo as antigas palavras de Protágoras ${ }^{46}$.

Tendo em vista as duas definições do termo humanismo e a obra plástica de Kounellis, suas entrevistas e textos, conjecturo que o artista almejava evocar o humanismo em todas as acepções quando definiu as dimensões de suas chapas de ferro ${ }^{(v)}$ (portanto de um elemento recorrentemente associado ao conceito de estrutura ${ }^{(v)}$ ) a partir do tamanho da cama $^{(v)}$ e do papel Fabriano ${ }^{(v)}$. A cama faz parte de um conjunto de objetos feitos a partir da escala ${ }^{(v)}$ humana que Kounellis usou em suas obras, sendo a mesa $^{(v)}$, a cadeira ${ }^{(v)}$ e a porta ${ }^{(v)}$ outros exemplos desse grupo de objetos. A escolha de Kounellis pela escala do corpo estabeleceu o contexto da vida humana e da cultura, para a leitura e compreensão de todos os demais materiais que compunham o léxico do artista. Por conseguinte, a medida dada pela folha de papel Fabriano ${ }^{(v)}$ remete tanto ao desenho - e à pintura - quanto ao surgimento da indústria papeleira italiana no século XIV, que abasteceu os prelos europeus responsáveis pela impressão dos textos clássicos que circulariam pela Itália renascentista.

\section{Imagem}

Kounellis, em diversas ocasiões ao longo de sua carreira, descreveu suas obras enquanto imagens produzidas e articuladas em função de suas referências artísticas e do contexto de exposição. Entretanto, o artista quase sempre delegou a fotógrafos profissionais - entre os quais, cabe destacar Claudio Abate, Aurelio Amendola e Manolis Baboussis - o registro de suas peças. As fotografias das obras e exposições se destinavam, em sua maioria, a catálogos e cartazes cuja produção e escolha eram minuciosamente acompanhadas, ou dirigidas, por Kounellis. Logo, ao folhearmos publicações sobre a obra de Kounellis, em grande parte, temos acesso ao processo de edição e seleção de imagens feito pelo próprio artista.
49 Vista da exposição fannis Kounellis. Galeria L'Attico, Roma, 1967. Foto: Claudio Abate. 


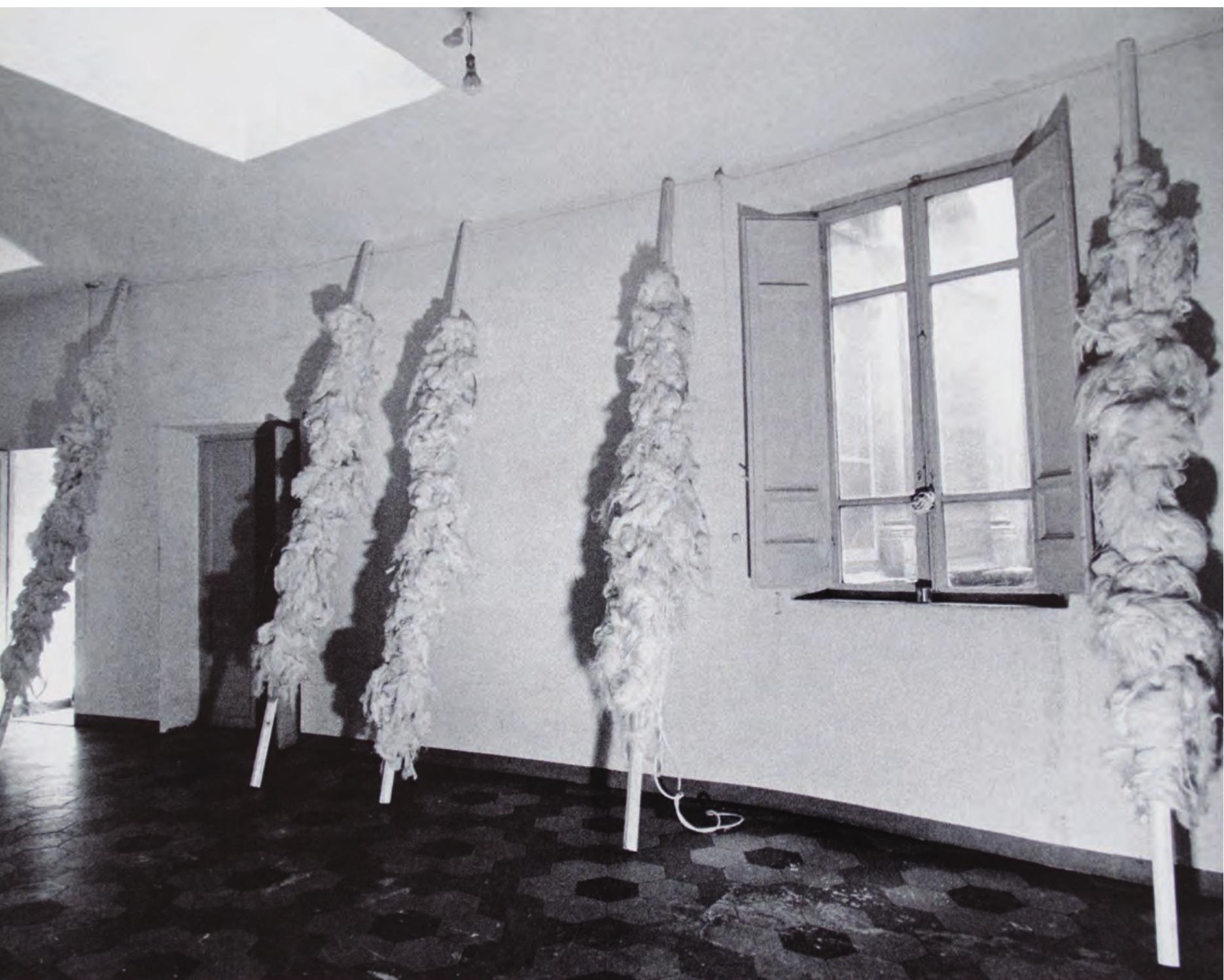


Nos catálogos podemos perceber que Kounellis não selecionou, necessariamente, a imagem que abarca todos os elementos do trabalho, mas a imagem que melhor descreve a obra e o contexto. Numa operação de síntese, elegia sempre o menor número possível de imagens para apresentar uma peça ou exposição. Esse procedimento de escolha se desdobra de um catálogo para outro quando percebemos a repetição de uma única imagem para apresentar a obra e, assim, saturar a memória do leitor pela acumulação ${ }^{(v)}$ da mesma imagem. Por exemplo, a fotografia que registra a obra Sem título (Cavalo), de 1969 (ver imagem 160), é a mesma utilizada em todos os catálogos que citam a obra, sendo que a imagem mostra onze cavalos, apesar da obra ser composta por doze animais vivos.

Cabe salientar também que Kounellis, ao descrever suas obras enquanto imagens, aproxima-as do campo da pintura $^{(v)}$, fazendo com que a repetição da imagem fotográfica encontre paralelo histórico com a gravura de tradução do século XV, que, além de reiterar os principais aspectos ligados ao desenho nas pinturas da época, era também um meio de divulgação e de construção imagética de artistas como Albrecht Dürer e Peter Paul Rubens.
50 Sem título, 1968. Cinco peças de madeira com trapo. $400 \mathrm{~cm}$ (altura) Foto: Claudio Abate.

\section{Instrumentos musicais}

Nos anos 1970, Kounellis realizou uma série de performances nas quais músicos profissionais executavam fragmentos selecionados pelo artista de peças eruditas. Contudo, na obra Homenagem à Louis Morris, de 1971 (ver imagem 4), a partitura da Sinfonia No. 9 em Mi menor "Do Novo Mundo", Op. 95, de Antonín Dvořák não é executada e o violino permanece em silêncio, enquanto Kounellis com as mãos sujas de tinta e sentado ao lado do instrumento leva a cabo a tarefa da espera. Nessa performance $^{(v)}$ o instrumento foi convertido em objeto, dado que sua presença não implica a execução da peça. Ao contrário, é a apresentação do instrumento musical que sugere a presença da música ${ }^{(v)}$. Dentro do repertório plástico de Kounellis, os instrumentos musicais articulam tanto o conceito de sensibilidade ${ }^{(v)}$ quanto o de estrutura ${ }^{(v)}$. O que determinava a associação desses objetos a cada um desses conceitos era o modo como Kounellis os dispunha no trabalho. Se davam suporte a outro elemento, como o fogo ${ }^{(v)}$, eram estruturas (ver imagem 91), porém se eram fixados a chapas ou suportes de ferro ${ }^{(v)}$, se referiam à sensibilidade (ver imagem 130). 


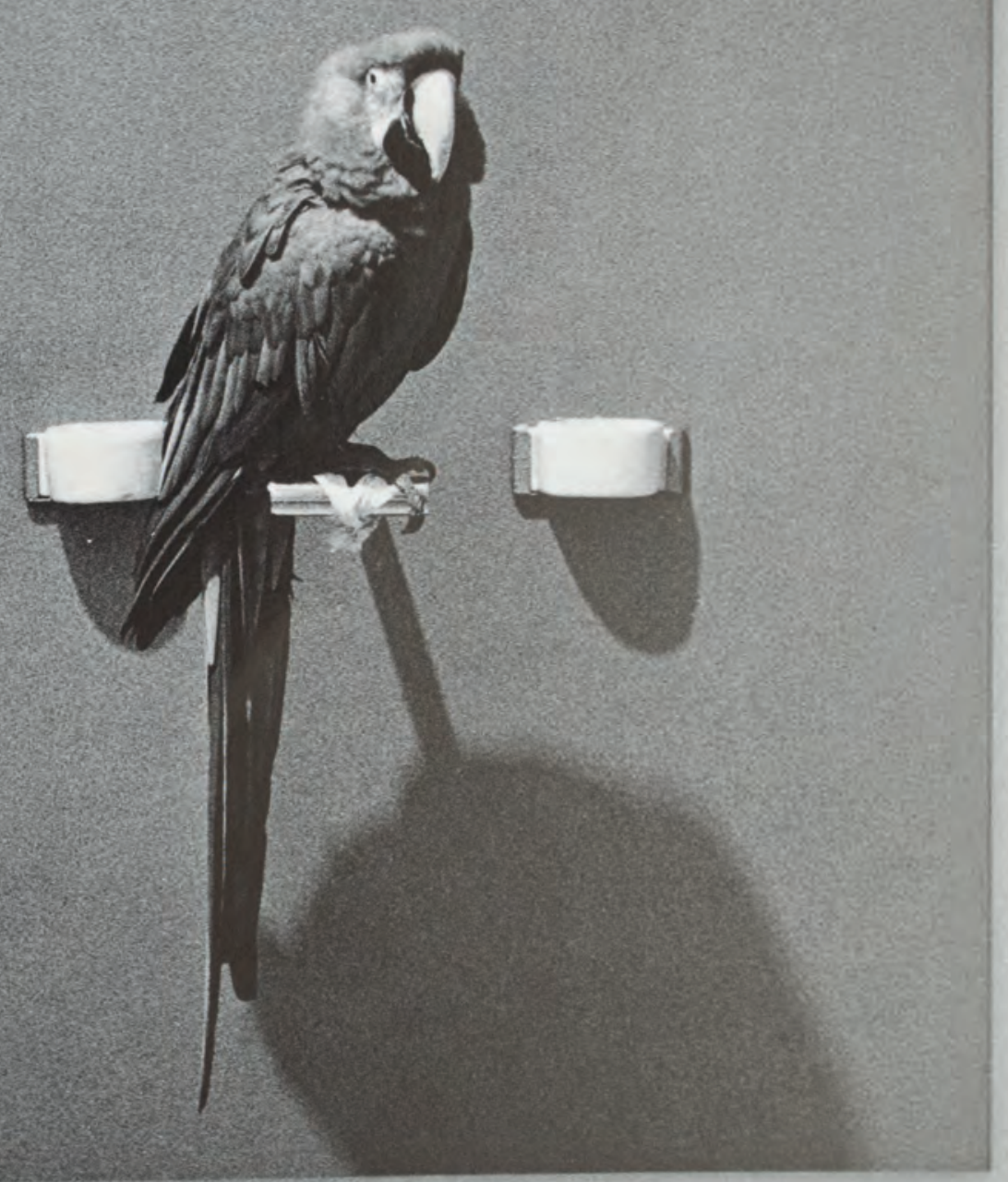


Janela

Em 1977, no Studio Tucci Russo, Kounellis, pela primeira vez, obstruiu com chapas de ferro $^{(v)}$ a janela do espaço expositivo ${ }^{(v)}$ quase em sua totalidade (ver imagem 174). Essa peça foi a primeira de um conjunto de obras que o artista realizou a partir do gesto de oclusão parcial ou total da janela, sendo a exposição individual realizada em 1985, no armazém portuário de Entrepôt Lainé um exemplo contundente do gesto de fechamento das janelas (ver imagem 107 e 108). Quando Kounellis obstruía as janelas reconfigurando a iluminação natural desses ambientes estabelecia uma nova dinâmica espacial que, em geral, destinava-se à potencialização imagética das outras obras apresentadas no mesmo lugar.

Klimt, Gustav (1862-1918)

Pintor austríaco. Klimt foi um pintor de formação acadêmica que rompeu com a Escola de Artes de Viena para fundar, junto com outros artistas, a Secessão de Vienense, cujo lema era: "A cada época a sua arte, à arte a liberdade". O interesse desse grupo de artistas era reposicionar de modo vanguardista a produção austríaca, tendo em vista os recentes desenvolvimentos da arte no restante da Europa e a os debates em torno da produção intelectual de Sigmund Freud.

Nesse contexto, Klimt realizou em suas pinturas diversos experimentos com formas abstratas - o que era encorajado pela Secessão. No entanto, o uso expressivo da linha e da cor realizado pelo artista se materializava através de técnicas acadêmicas como a têmpera e o uso da folha de ouro ${ }^{(v)}$. Isso fez com que a obra de Klimt fosse compreendida como expressão conceitual e técnica do conflito entre a subjetividade individual e a autoridade acadêmica, e, portanto, marcada pela constante oscilação entre a figuração e a abstração.

Kounellis evoca Klimt, quase sempre, para apontá-lo como uma de suas referências artísticas para o uso do ouro em suas obras (ver imagens 17 e 59). Porém, na poética de Klimt, em seu contexto e procedimentos internos, encontramos também um ponto crucial para a formulação da linguagem ${ }^{(v)}$ da pintura $^{(v)}$ do século XX, baseada na tensão entre a linguagem da pintura já consolidada e a investigação artística que busca através das técnicas disponíveis abrir novos caminhos. 


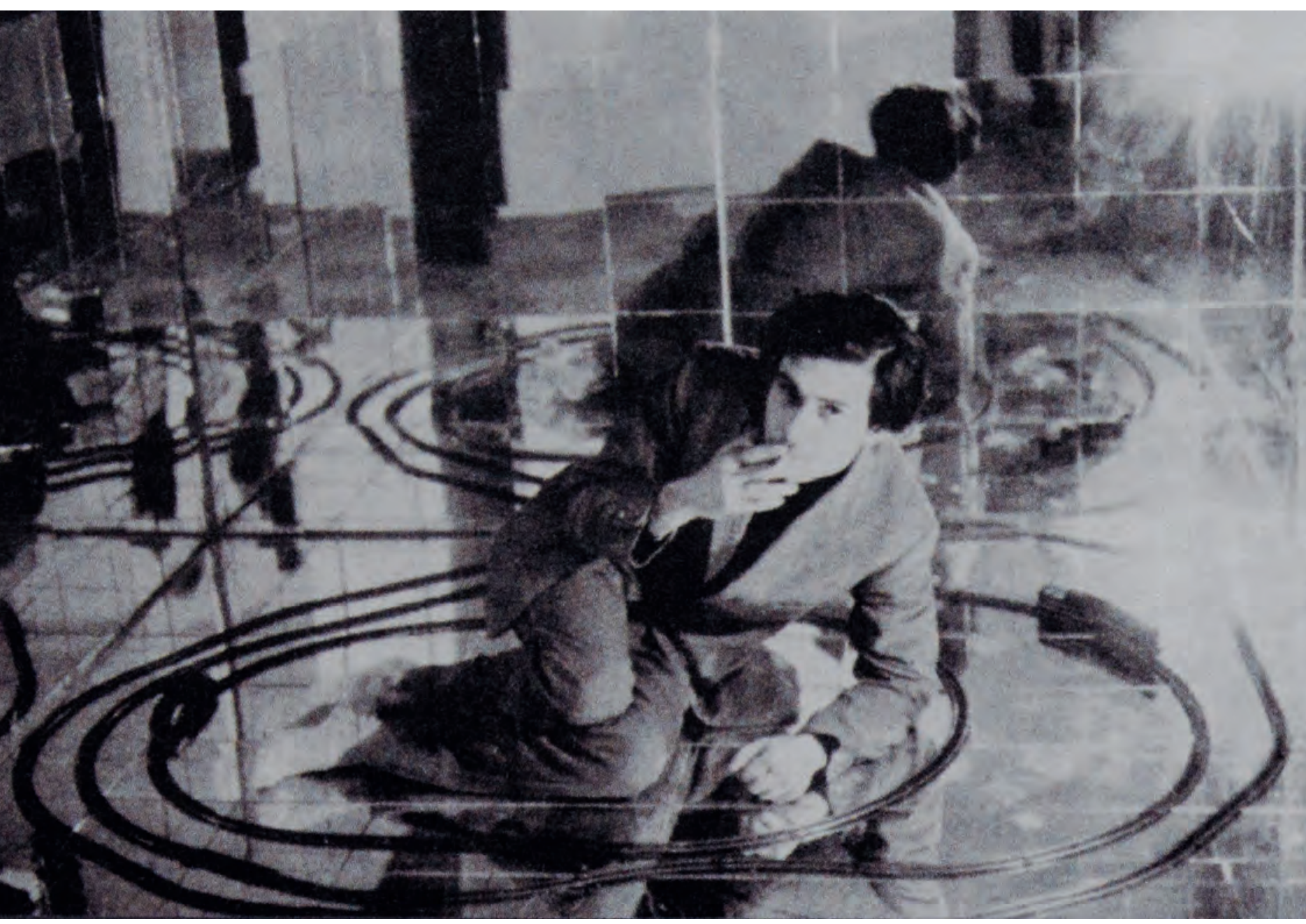

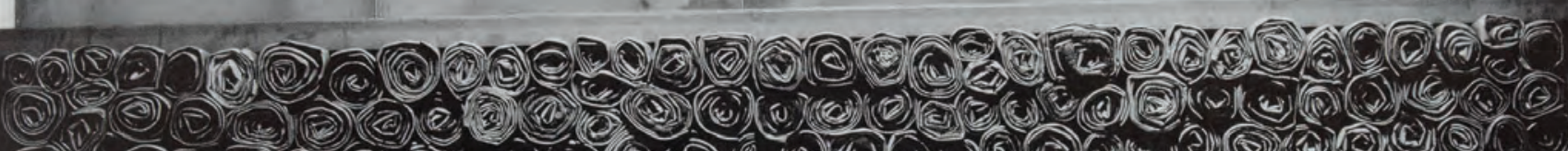

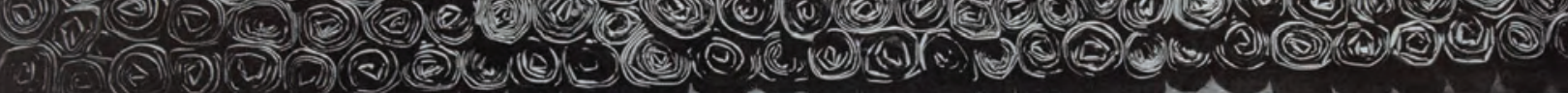

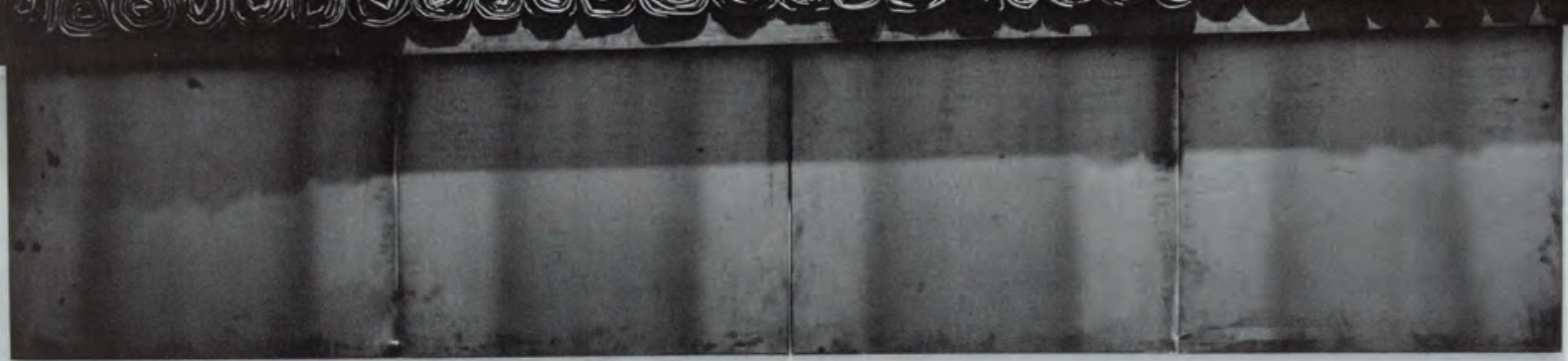


Identifico, nesse sentido, um paralelo com uma breve definição de arte tecida por Kounellis, em 1985, que recupera o lema da secessão: “a arte, como toda poesia, nasce de uma falta e é visionária pela mesma razão. A linguagem que nasce com o artista é nela investida e representa a realidade histórica" ${ }^{47}$.

La Tour, Georges de (1593-1652)

Pintor francês. Kounellis foi particularmente interessado pela precisão da representação do fogo ${ }^{(v)}$ feita por La Tour e ao modo como ela "criava sombras, volumes marcados e, com alguns toques aqui e ali, determinava a imagem" $"$.

La Tour foi um pintor $^{(v)}$ do século XVII que desenvolveu a técnica do chiaroescuro, tendo como referência a obra de Caravaggio ${ }^{(v)}$. Porém, diferentemente de Caravaggio, La Tour apresentava em sua pintura ${ }^{(v)}$ as fontes de luz que desenhavam o contorno de suas figuras. De certa maneira, a escolha de La Tour por pintar a fonte de luz revela, em parte, o processo de criação da imagem ${ }^{(v)}$, pois, como em Caravaggio, trata-se de uma imagem cuja construção pictórica se dá através do olhar do artista, e não de modelos ideais.

\section{Labirinto}

É que o labirinto - e sua associação com a caverna o mostra bem - deve, ao mesmo tempo, permitir o acesso ao centro por uma espécie de viagem iniciatória, e proibi-lo àqueles que não são qualificados ${ }^{49}$.

Nas décadas de 1980 e 1990, Kounellis começa a reapresentar obras de grandes dimensões em novos contextos. Nessas remontagens a nova situação expositiva, na maioria dos casos, não corresponde à anterior. Logo, a montagem dessas peças no espaço expositivo ${ }^{(v)}$, por seu descompasso com a nova situação arquitetônica, redesenha o ambiente (ver imagens na sequência 64, 65, 66 e 67).

A ideia de labirinto foi desenvolvida inicialmente por Kounellis na exposição realizada em 1985, no CAPC Museu de Arte Contemporânea de Bordeaux, no armazém portuário de Entrepôt Lainé (ver imagens 107 e 108). Nessa mostra Kounellis redesenhou o espaço expositivo, ao dispor suas obras em locais de passagem, obstruindo parcialmente
52 Jannis Kounellis

performando Sem título,

1967. Espelhos, madeira,

trens em miniatura,

microfones e Kounellis

repetindo várias sentenças.

Foto: Claudio Abate.

53 Sem título, 1998.

Ferro, chumbo e roupas.

$200 \times 360 \mathrm{~cm}$. Foto:

Manolis Baboussis.
47 (KOUNELLIS; CODOGNATO; D'ARGENZIO, 2002, p. 211).

48 (KOUNELLIS; CODOGNATO; D'ARGENZIO, 2002, p. 97). 49 (CHEVALIER; GHEERBRANT, 2018, p. 530, grifos dos autores). 

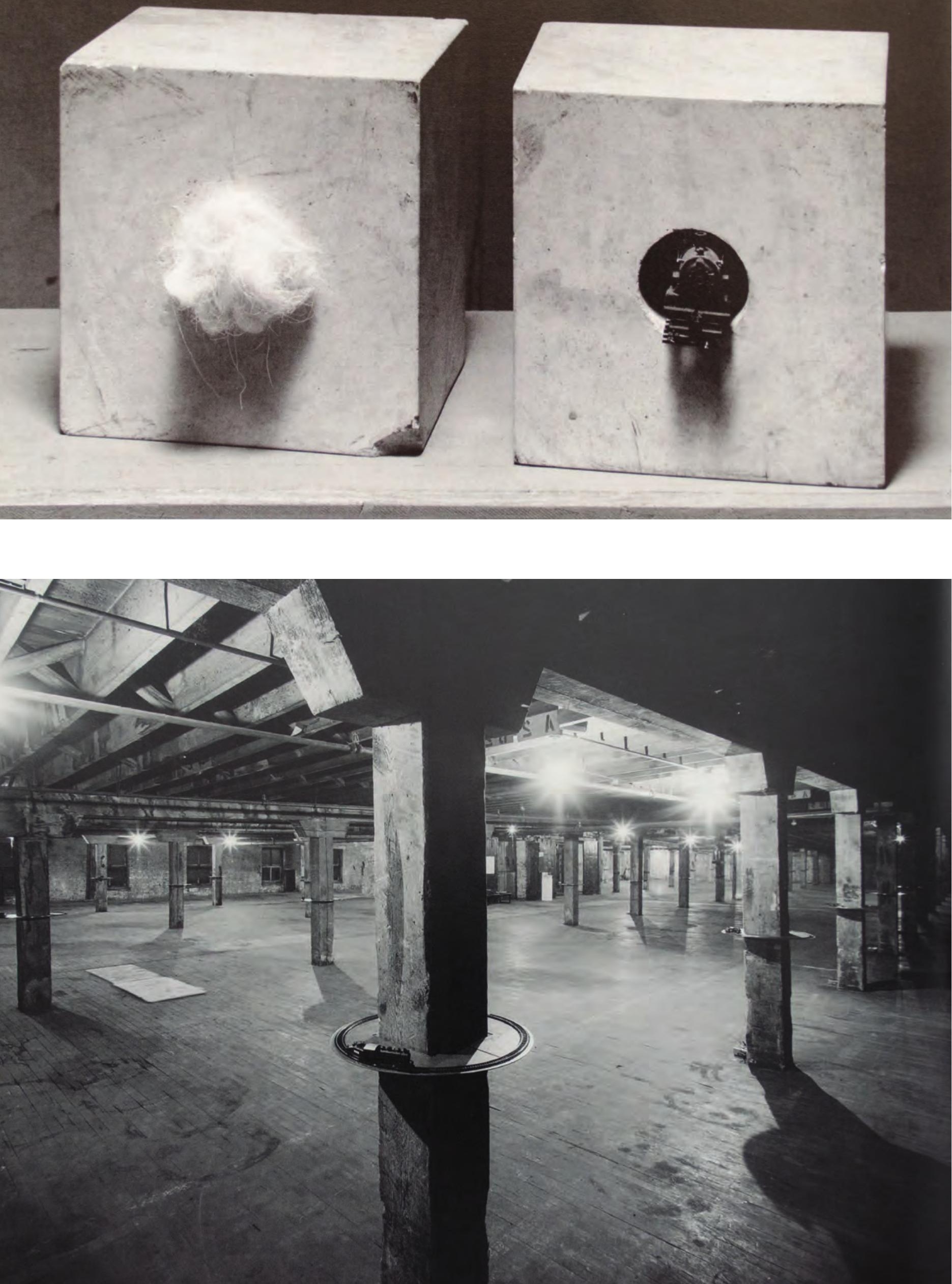
as fontes naturais de luz. O resultado foi a criação de um labirinto sombrio que, segundo Marc Scheps, produzia uma atmosfera de tensão que era amplificada pelo ruído provocado pelas dezenas de maçaricos que faziam parte das obras e pelo forte odor do gás expelido e não queimado pelos maçaricos ${ }^{50}$. Posteriormente, nos anos 2000, Kounellis elabora, para diferentes exposições, um labirinto de ferro ${ }^{(v)}$ que recebe suas obras, formando, assim, uma grande obra única (ver imagens 96, 97, 98, 99, 100 e 131). Ainda, sobre a configuração espacial dos labirintos produzidos por Kounellis cabe pontuar uma especificidade:

O neoclassicismo é baseado em uma ideia simétrica, enquanto eu sou assimétrico [...] o labirinto que fiz também é assimétrico, enquanto todos os labirintos que você vê em jardins ou grandes parques são simétricos [...] eu entendo a assimetria como uma fonte misteriosa; com isso, quero dizer que não excluo esse mistério... Talvez o senso de mistério seja o único aspecto da Grécia que ainda tenho dentro de $\mathrm{mim}^{51}$.

A assimetria do labirinto de Kounellis reitera o aspecto simbólico do labirinto como "viagem iniciática", se entendermos a ideia de mistério como algo que é oculto aos "não iniciados" e protegido dos "não qualificados".

Entretanto, o labirinto não se resume à sua configuração arquitetônica, outro aspecto de relevo diz respeito ao que ele guarda ou esconde. Nesse sentido, ao preencher o labirinto com suas obras, Kounellis estabelece como centro dessa arquitetura sua própria poética. $\mathrm{O}$ que parece se relacionar com o problema da linguagem ${ }^{(v)}$ descrito pelo $\operatorname{artista}^{(v)}$ em "O Julgamento de K." e "Para meus alunos em Düsseldorf" e postos pela necessidade da determinação de um centro e sua verticalização.

Porém, é preciso comentar o aspecto mítico do labirinto que, construído na Ilha de Creta por Dédalo sob encomenda do rei Minos, guardava, em seu interior, o terrível Minotauro. Foi Teseu quem adentrou o labirinto, matou o Minotauro e só conseguiu escapar de imbricada arquitetura graças a um fio de novelo que marcava o caminho por ele percorrido. Depois do triunfo de Teseu sobre o Minotauro, Dédalo e seu filho, Ícaro, foram aprisionados pelo rei Minos no labirinto como punição pelos feitos do herói ateniense. Para escapar de sua criação, Dédalo projeta e fabrica dois pares de asas para voar sobre as paredes do labirinto junto com Ícaro. Dédalo consegue escapar de sua criação, no entanto, Ícaro, atraído pelo sol, morre quando a cera de suas asas derrete com o calor.
54 Sem título, 1966.

Mármore, trapo e

miniatura de locomotiva. $15 \times 20 \times 22 \mathrm{~cm}$. Foto: Aurelio Amendola. 55 Sem título, 1986. Quarenta e duas locomotivas em miniatura funcionando ao redor de colunas de madeira. Foto: Claudio Abate. 

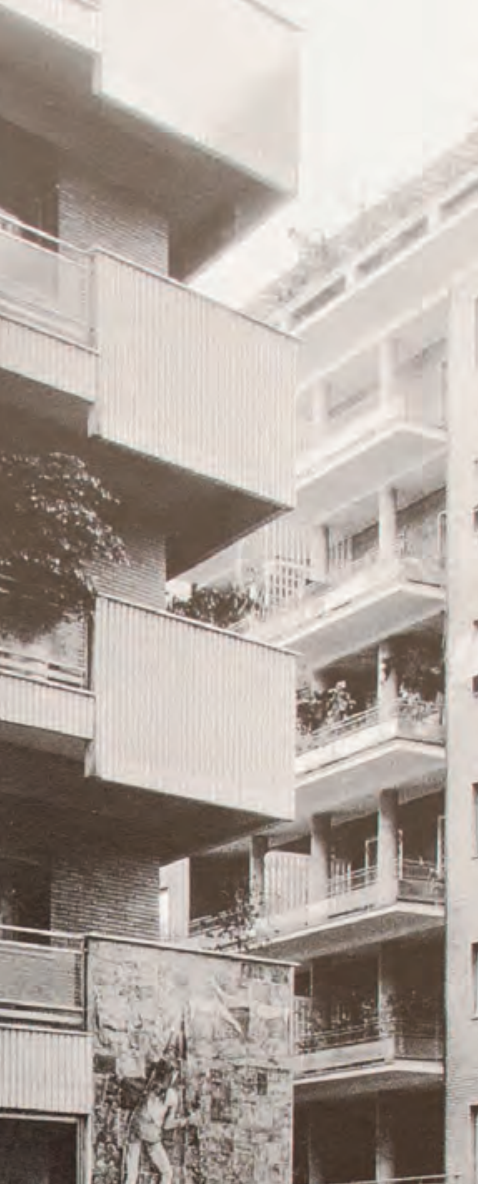

IIIIIII

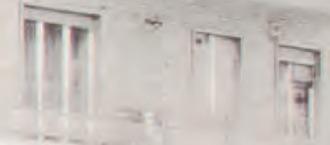

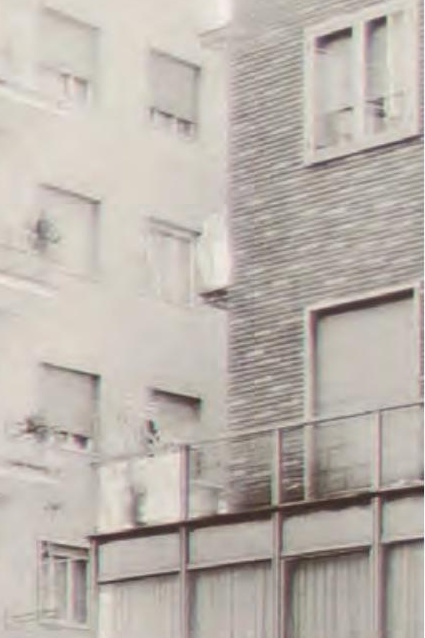

.

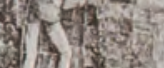

in 6400

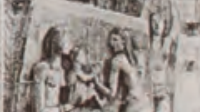

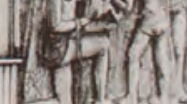

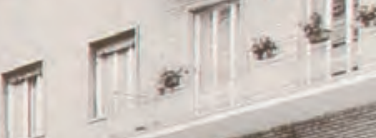

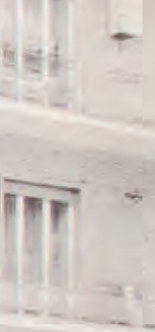
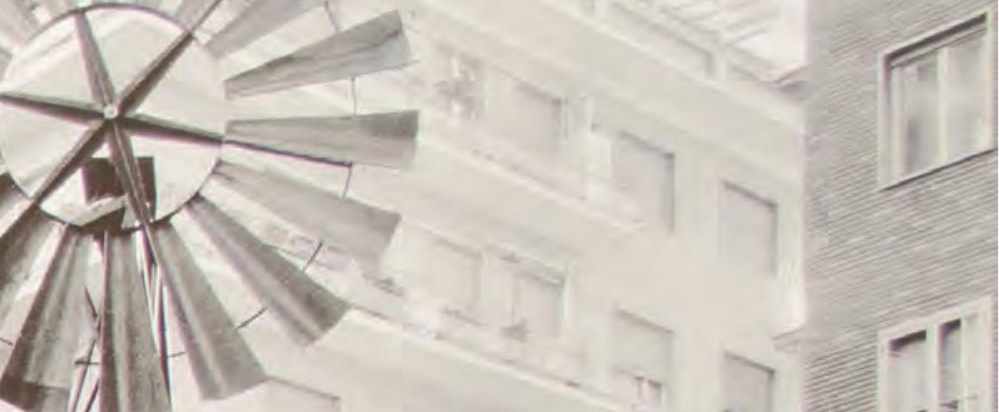

$1+2+3$

$\frac{1}{4}$

$\therefore$ 积

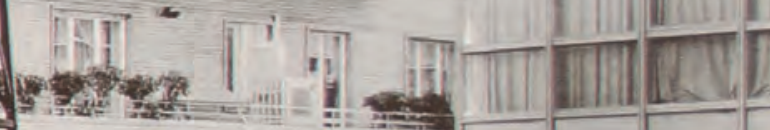

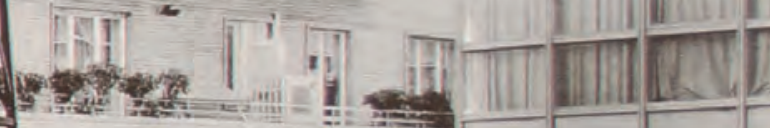

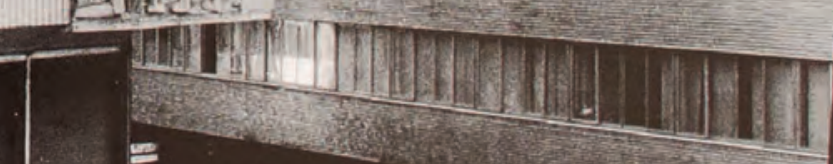

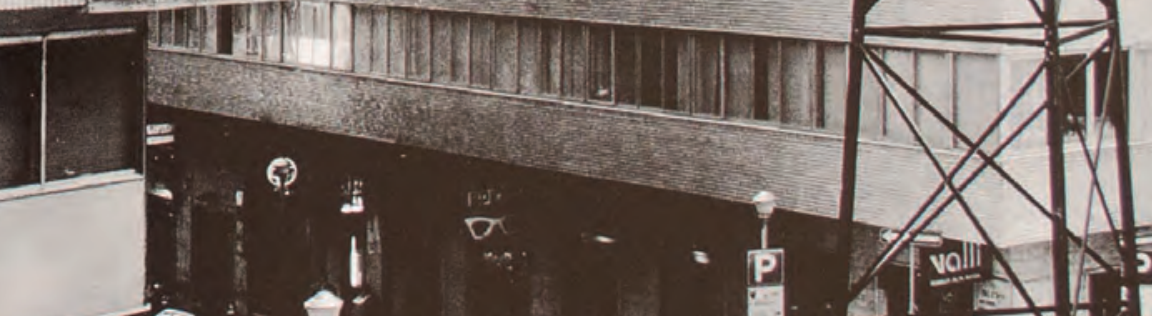

$2 p^{12}=0^{2}=1$

A

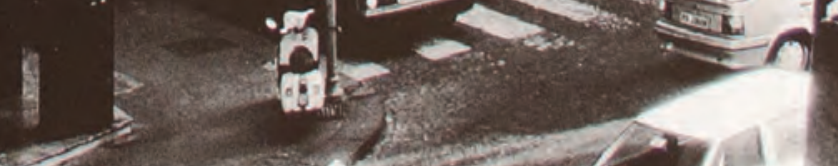

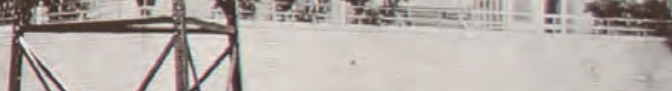


No mito, o labirinto é a expressão da linguagem arquitetônica elaborada por Dédalo e conhecida por Teseu, que consegue entrar e sair dessa arquitetura. A construção de Dédalo e a movimentação de Teseu pelo labirinto são pensadas em função do centro, aqui simbolizado pelo Minotauro. Por conseguinte, a fuga aérea de Dédalo releva a verticalidade como um desdobramento da linguagem já consolidada.

A imagem ${ }^{(v)}$ do labirinto também produz uma representação visual para a ideia de cavidade teatral $^{(v)}$ e está, igualmente, associada ao conceito de catedral $^{(\mathrm{v})}$ sobretudo pela presença de formas labirínticas no interior das catedrais, sendo essas destinadas à "simulação" de viagens para fiéis que não dispunham de recursos para fazer tais peregrinações [ver centralidade ${ }^{(v)}$ e verticalidade $^{(v)}$ ].

\section{Linguagem}

A linguagem artística, para Kounellis, foi a junção indissociável entre técnica e teoria, entre o fazer e a conceitualização. Isso é perceptível na distinção entre pintura $^{(v)}$ e afresco $^{(v)}$, por ele pontuada, e na formulação dos conceitos de cavidade teatral ${ }^{(v)}$, acumulação $^{(v)}$, estrutura $^{(v)}$ e sensibilidade $^{(v)}$. Para cada um dos conceitos elencados, Kounellis reconheceu e apontou uma história que pertence à arte e aos seus meios e cujo guardião ${ }^{(v)}$ é o $\operatorname{artista}^{(v)}$.

Segundo Kounellis, o conhecimento guardado pelo artista não é estático, pois cada um deles adiciona à linguagem da arte seus "acentos pessoais" resultantes da percepção de sua respectiva realidade histórica. Foi através da concepção de linguagem artística da apresentação ${ }^{(v)}$ que Kounellis se afirmou como pintor $^{(v)}$, a despeito de suas obras não apresentarem qualquer semelhança visual ou material com a ideia de pintura que corresponde à tinta sobre tela.

Em "Para meus alunos em Düsseldorf", Kounellis expôs a difícil tarefa da construção da linguagem artística, associando o problema aos conceitos de centralidade ${ }^{(v)}$ e verticalidade ${ }^{(v)}$, e sugestionando a imagem $^{(\mathrm{v})}$ da catedral ${ }^{(\mathrm{v})}$ como metáfora para esse processo.

\section{Litania}

A litania é um canto religioso que progride lentamente à medida que se repete e, a cada repetição, insere uma pequena variação. Em "Omelia",
56 Sem título, 1996.

Moinho de vento instalado permanentemente na Praça do Plebiscito, Nápoles. $125 \times 40 \times 40 \mathrm{~cm}$. Foto: Peppe Avallone. 

de 1985, escrito por Kounellis e publicado na revista AEIUO, de Roma, o artista cita seu interesse pelas litanias. Nesse texto somos levados a supor que são as sutis variações e progressões da litania que diferem a produção artística europeia da americana, pois do lado europeu a acumulação $^{(\mathrm{v})}$ permitiu o avanço e, do lado americano, a repetição industrial.

Em 2001, Gloria Moure afirma que o processo de trabalho de Kounellis articula a mesma lógica construída pela litania:

A repetição em Kounellis tem uma base metafórica e não uma lógica técnica destrutiva. Essa base é a calmante litania sagrada, que libera em vez de agredir e consolida em vez de dissipar. De qualquer forma, se o traço de serialização está presente na forma da multiplicidade do objeto em si, isso serve para exaltá-lo, e não depreciá-1o ${ }^{52}$.

A ideia de associar a repetição rítmica da litania à produção de Kounellis vai ao encontro do conceito de acumulação desenvolvido pelo artista, sobretudo no que diz respeito à junção de obras já existentes e à remontagem de peças "modeladas" a partir da arquitetura em novas situações espaciais (ver imagens 142, 148 e 150). Ela também ressoa na ideia de partitura ${ }^{(v)}$ presente nas composições pictóricas dos anos 1950 e que se mantém nas obras das décadas posteriores (ver imagens na sequência $7,8,129,10,11$ e 36).

Associo a litania, igualmente, ao processo de seleção de imagens realizado por Kounellis para seus livros e catálogos. Aqui cada imagem ${ }^{(v)}$ sem título ${ }^{(v)}$ corresponde a um fragmento $^{(v)}$ da litania. As partes em si não mudam, mas seu ordenamento varia a cada publicação em função do que a própria imagem apresenta. Essa repetição e associação de imagens baseada nas relações entre fragmentos estabelece uma narrativa visual na qual o andamento era variável, mas a progressão, uma constante.

\section{Livro}

O livro foi um dos objetos que Kounellis utilizou enquanto sensibilidade $^{(\mathrm{v})}$. Diferentemente dos demais objetos, materiais e seres vivos que o artista associou à sensibilidade, o livro guarda em si um desdobramento da escala humana. Trata-se da dimensão da memória, conforme pontua Jorge Luis Borges em palestra realizada na Universidade de Belgrano, em 1979:
57 Sem título, 1979. Tela, madeira, corda e fuligem. $400 \times 115 \times 45 \mathrm{~cm}$. Foto: Claudio Abate. 


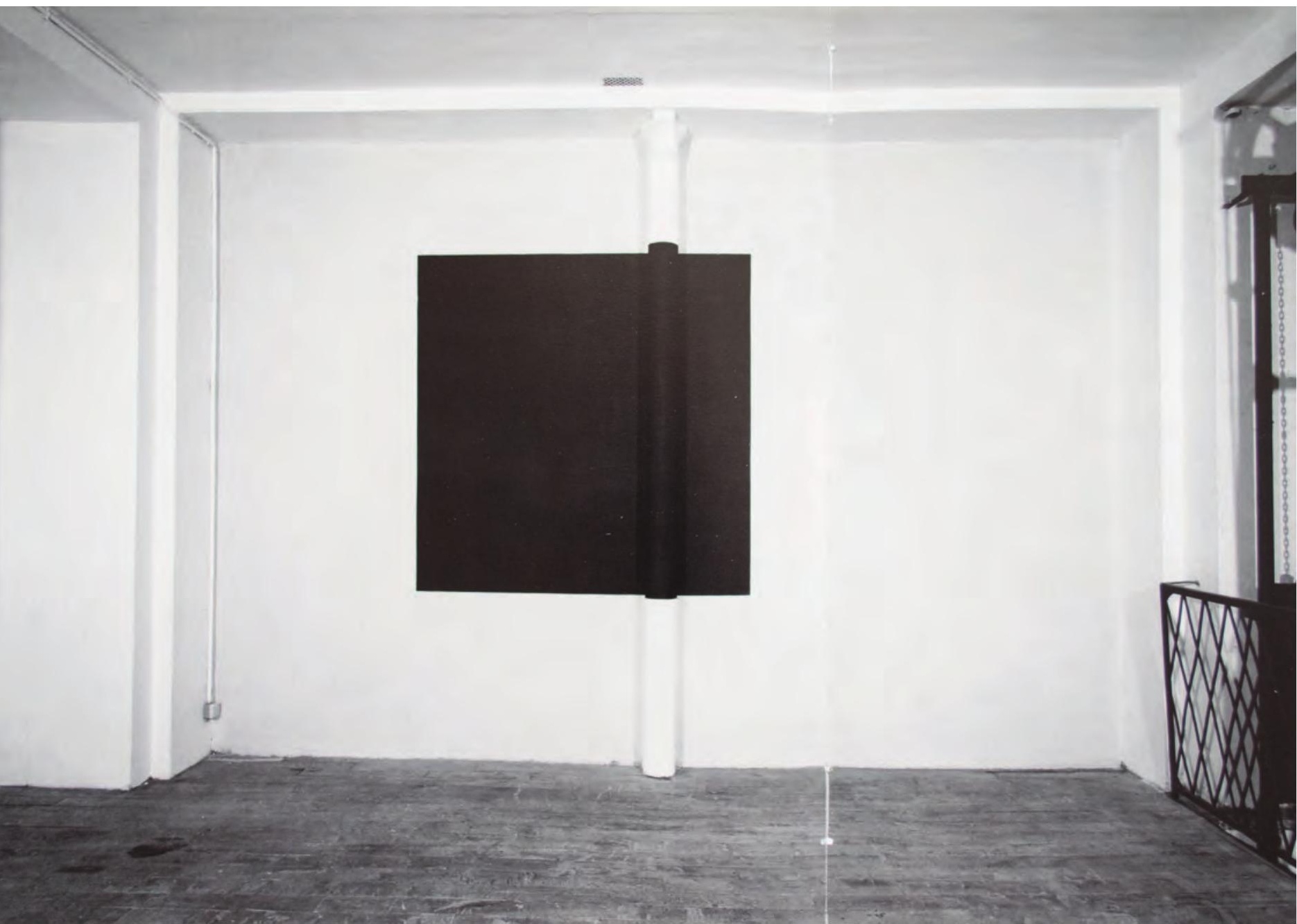


Dos diversos instrumentos do homem, o mais assombroso, sem dúvida, é o livro. Os demais são extensões de seu corpo. O microscópio, o telescópio, são extensões de sua vista; o telefone é extensão da voz; depois temos o arado e a espada, extensões de seu braço. Mas o livro é outra coisa: o livro é uma extensão da memória e da imaginação ${ }^{53}$.

No interior da poética de Kounellis podemos localizar o livro junto ao interesse do artista pelo humanismo ${ }^{(v)}$, dado que no século XV o livro impresso foi o principal meio de divulgação da cultura humanista por meio da difusão dos textos clássicos.

O livro, em geral, foi usado por Kounellis na construção de paredes em portas e janelas que, no caso, dimensionavam a escala ${ }^{(v)}$ mental a partir da física (ver imagens 188) $\left[\operatorname{ver~parede~}^{(v)}\right.$ porta $^{(v)}$ e janela $\left.^{(v)}\right]$.

\section{Locomotiva}

Locomotivas em miniatura e outros objetos ligados ao universo ferroviário, como vigas de ferro ${ }^{(v)}$ emulando trilhos férreos, foram utilizados por Kounellis para sugerir a noção de deslocamento e, assim, materializar a imagem $^{(v)}$ da viagem ${ }^{(v)}$. Carrinhos com roda sugerindo vagões de carga também se relacionam à locomotiva e reforçam a ideias de mobilidade, comércio e ciclo produtivo apresentada por materiais como sacos de juta ${ }^{(v)}$, café $^{(v)}$ e carvão ${ }^{(v)}$. Uma das primeiras alusões de Kounellis ao universo ferroviário acontece na exposição Os jogos de Kounellis, em 1967, na Galeria L'Attico. Nessa mostra o artista montou três trilhos concêntricos no interior de uma sala espelhada e, em cada um dos trilhos, dispôs uma locomotiva de brinquedo; completando a peça, Kounellis permaneceu em cena repetindo algumas frases (ver imagem 52). Nessa obra o som das locomotivas foi amplificado por microfones e criava uma espécie de litania ${ }^{(v)}$ em conjunto com a voz do artista.

Em 1977, no claustro da Igreja de Santa Maria Novella, Kounellis instalou ao redor de uma coluna ${ }^{(v)}$ um trem elétrico de brinquedo, estabelecendo novamente um percurso cíclico (ver imagem 2). No claustro, o eixo vertical da coluna serve tanto para a sustentação do edifício quanto para os aspectos simbólicos da construção. Suponho que esse trabalho foi pensado a partir da relação entre a Igreja de Santa Maria Novella e a estação de trem de mesmo nome, localizada nas imediações do edifício. O trem como símbolo da mobilidade, em 


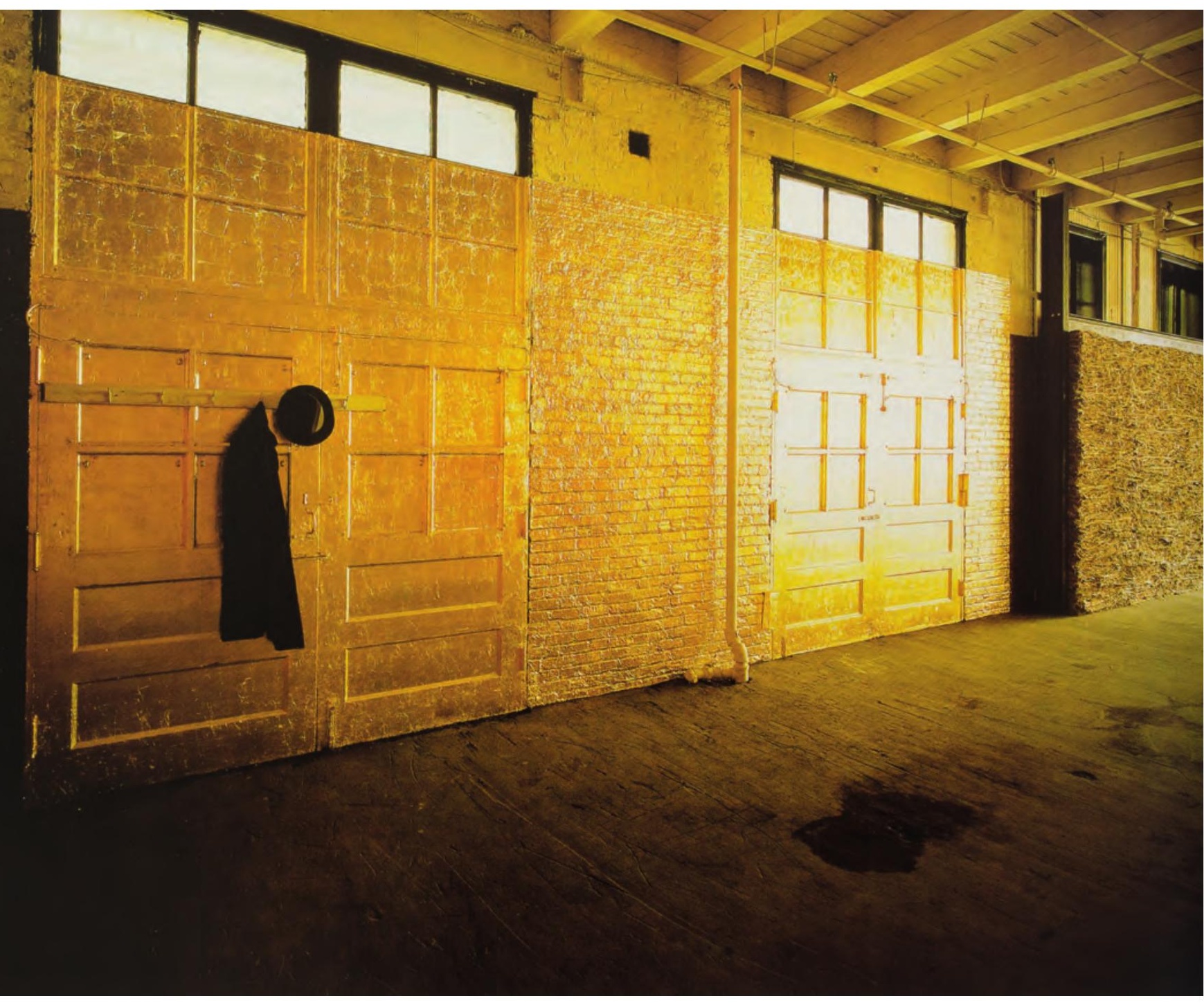


associação ao encerramento do convento, revela o aspecto simbólico da construção do claustro como uma estação na rota do caminho da santificação religiosa alcançada pela repetição cíclica de preces e orações, ou seja, aqui há, mais uma vez, um espelhamento da estrutura $^{(\mathrm{v})}$ da litania.

Posteriormente, em 1986, em Chicago, na exposição Fannis Kounellis: retrospectiva em cinco locações, Kounellis fixou, nas colunas do antigo armazém localizado na West Ontario Street, 42 trilhos concêntricos com locomotivas elétricas. No antigo armazém, diferentemente do claustro onde o percurso do trem aludia ao caminho da purificação espiritual, pela quantidade e pelo som produzido pelo deslocamento das locomotivas, os trens de brinquedo evocam o tempo da máquina e da produção industrial (ver imagem 55).

Malevich, Kazimir (1879-1935)

Pintor russo. Fundador do Suprematismo, Malevich foi um pintor cuja obra inaugura um novo sistema simbólico para a arte baseado na economia dos signos que, segundo o próprio artista, era representada pelo quadrado $^{(\mathrm{v})}$ preto. A concepção de Malevich foi, anos mais tarde, lida pela crítica greenberguiana e, posteriormente, pelos artistas minimalistas como uma espécie de ruptura com a linguagem ${ }^{(v)} \mathrm{da}$ pintura $^{(v)}$; no entanto, para o artista essa economia era uma tendência que não expressava uma ruptura, mas um nascimento:

A energia mundial se orienta para a economia, e cada passo seu para o infinito se expressa numa nova cultura econômica dos signos; a revolução é tão somente a dedução de uma nova energia econômica que acalenta a intuição mundial. [...] a revolução sempre se funda na pulverização de todas as deduções econômicas anteriores. A arte evolui sem rupturas porque nela vive a mesma energia, com a mesma finalidade única e infinita ${ }^{54}$.

O quadrado negro é uma criança majestosa cheia de vida. É o primeiro passo da criação pura em arte ${ }^{55}$.

Kounellis citou Malevich em textos e obras como "Omelia", Sem título, de 1973, e Sem título, de 1984. Para ele, a síntese promovida pelo artista se referia à economia imagética dos ícones religiosos russos e articulava, assim, uma lógica da pintura que se aproximava de uma cosmogonia (ver imagens 58 e 60).
59 Sem título (Tragédia Civil), 1986. Parede coberta com folhas de ouro, porta casacos, chapéu e casaco. Foto: Claudio Abate. 

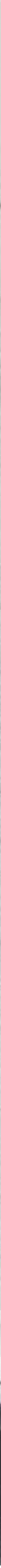


\section{Mancha}

A mancha feita de tinta foi uma das poucas manifestações gestuais que Kounellis preservou em seus trabalhos. Ela estabelece dentro do vocabulário plástico de Kounellis uma ligação com a linguagem ${ }^{(v)}$ pictórica convencional, em especial com a pintura abstrata informal dos expressionistas abstratos norte-americanos.

No entanto, o artista usou, da mesma forma, manchas de fuligem feitas por fumaça ${ }^{(v)}$. Porém, se a mancha de tinta aproxima Kounellis da abstração, a mancha de fuligem remete a outro tempo e momento histórico da pintura ${ }^{(v)}$.

É importante frisar que as manchas produzidas por Kounellis quase sempre permaneceram contidas no interior de um perímetro ${ }^{(v)}$ seja ele dado por uma chapa de ferro ${ }^{(v)}$ seja por um conjunto de cadeiras (ver imagens 94, 98 e 104).

\section{Máquina de costura}

A máquina de costura é um objeto que se relaciona ao conceito de sensibilidade $^{(v)}$ e, dentro da poética de Kounellis, evoca sobretudo a imagem $^{(v)}$ da produção têxtil industrial (ver imagens 16, 81, 82 e 195). Embora a presença da máquina de costura nas obras do artista afirmasse a disponibilidade de um recurso técnico e mecânico, Kounellis quase sempre optou por soluções manuais para juntar tecidos, sejam eles procedentes de saco de juta $^{(v)}$ sejam de peças de vestuário ${ }^{(v)}$.

A máquina de costura também sugere o imaginário surrealista, presente na frase do Conde de Lautréamont: “Tão belo quanto o encontro fortuito de uma máquina de costura e um guarda-chuva sobre uma mesa anatômica" ${ }^{56}$. A enigmática sentença foi parcialmente retomada por Man Ray em O enigma de Isidore Ducasse, obra na qual o artista embrulha com tecido uma máquina de costura, sendo o título desse ready-made uma recordação de que Conde de Lautréamont era um codinome usado por Isidore Ducasse.

É importante pontuar que a afirmação de Lautréamont ao listar três objetos aparentemente aleatórios para definir a ideia de beleza guarda ligações com o humanismo ${ }^{(v)}$, pois, grosso modo, máquina de costura, guarda-chuva e mesa de autópsia são objetos projetados a partir da escala $^{(v)}$ do corpo.
60 Sem título, 1973. Tela preta sobre madeira com oito fragmentos de estátuas de gesso e o filho de Kounellis. $300 \times 300 \mathrm{~cm}$. Foto: Claudio Abate. 

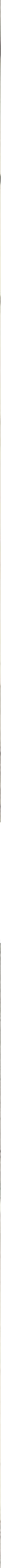
Pintor italiano. Em monografia sobre a obra de Kounellis, Stephen Bann retoma a ideia de Giorgio Vasari sobre a obra de Masaccio enquanto um "pioneiro do bom fazer pictórico" para associar o problema do peso $^{(\mathrm{v})}$ ao problema da representação no sistema da perspectiva. Segundo Vasari e Bann, as figuras de Masaccio são as primeiras a possuírem peso, ou seja, respondem às forças da gravidade que atuam no mundo real esquadrinhado pela perspectiva. Logo, o peso seria uma questão da pintura, pois sem ele a representação - por mais que siga os preceitos do sistema da representação em perspectiva - seria uma abstração do real.

Kounellis, ao evocar Masaccio, estava ciente dessa relação e aprofunda o problema, quando afirma que o peso era também uma escolha estética e moral realizada pelo artista $^{(v) 57}$. Em outras palavras, Kounellis reitera o compromisso da arte com a realidade, distanciando sua produção de conceitos como o simulacro, por exemplo.

\section{Máscara}

A máscara, assim como a coluna ${ }^{(v)}$, é um dos objetos que simboliza a intermediação entre o terreno e o sagrado. Kounellis, nas décadas de 1970, 1980 e 1990, elaborou diferentes obras nas quais construía máscaras a partir da obstrução da boca ${ }^{(v)}$ (ver imagens 3, 74, 109, 149 e $185)$.

Além de criar suas próprias máscaras, Kounellis fez igualmente uso de máscaras já existentes. Nos anos de 1970, o artista realizou um conjunto de performances em que utilizava, em variadas situações, uma máscara em gesso que representava Apolo - o deus do sol -, que, inclusive, tem o seu culto associado às artes (ver imagens 19, 77, 78, 79 e 106). Embora a máscara oculte a identidade de Kounellis, ela revela a quem vê o artista mascarado uma nova presença cujo significado se relaciona à figura de Apolo.

Em Sem título, de 1974, por exemplo, Kounellis pinta de amarelo o espaço expositivo $^{(v)}$ e permanece no ambiente montado em um cavalo $^{(v)}$, enquanto usa a máscara de Apolo; contudo, os espectadores

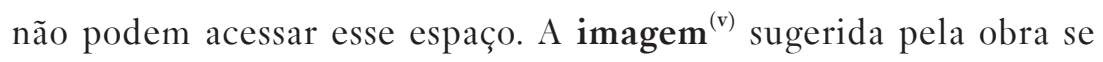
aproxima da visualidade das pinturas de $\mathbf{R u b l e v}^{(\mathrm{v})}$ e da Escola de Siena, 


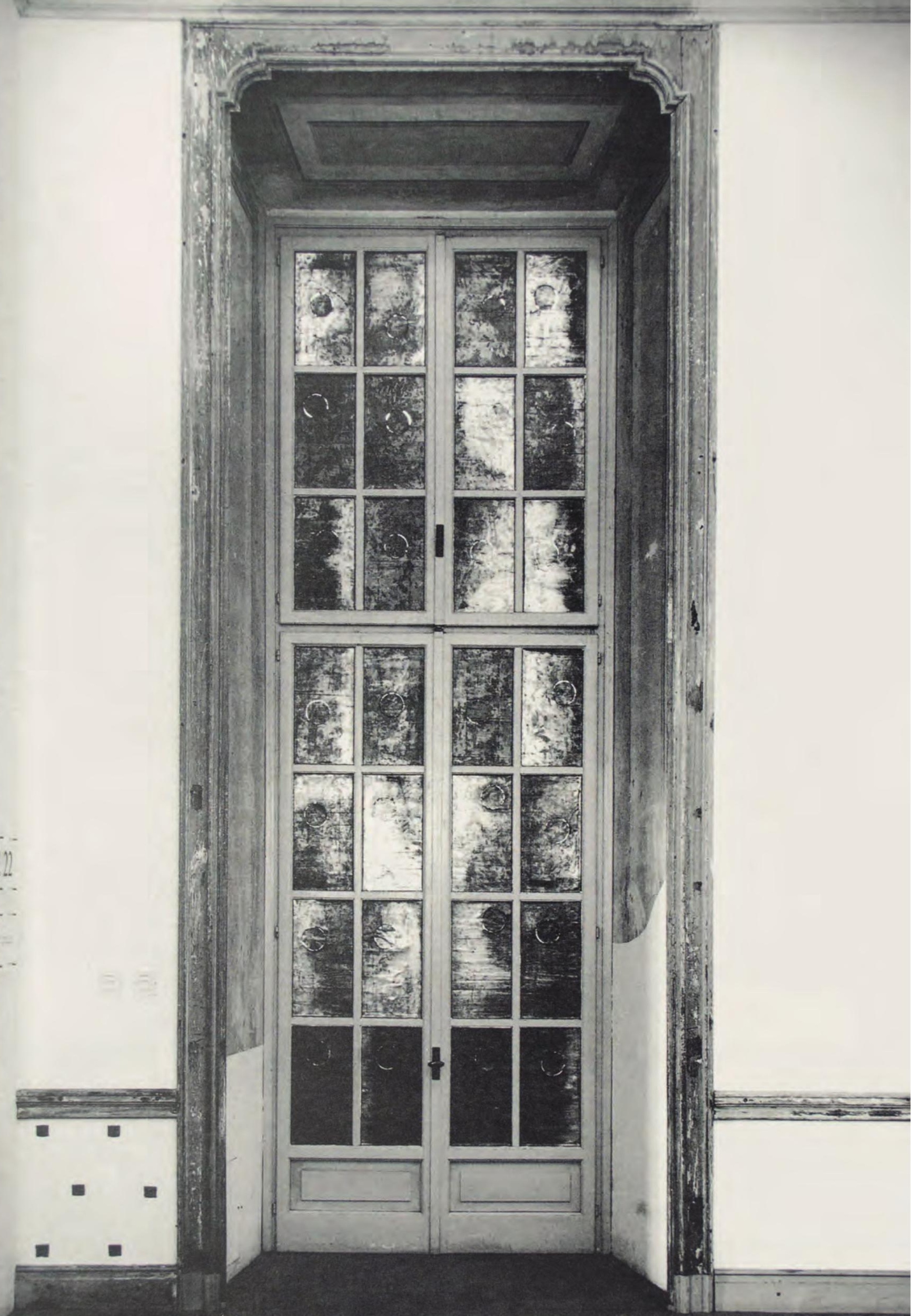


nas quais o fundo em ouro ${ }^{(v)}$ apresenta um espaço sagrado onde a figura se encontra. Na performance ${ }^{(v)}$ de Kounellis o espaço da galeria tornase o lugar da aparição de Apolo, e essa hierofania institui uma nova dinâmica de percepção espacial e temporal.

\section{Mesa}

No repertório de materiais e formas de Kounellis, a mesa é um elemento que reitera nas obras a escala humana, como o fazem a cama ${ }^{(v)}$ e a cadeira ${ }^{(v)}$, por exemplo. Para Francis Ponge, a mesa é o local onde o homem trabalha - com as mãos e com o intelecto - e se alimenta tanto o corpo quanto a alma ${ }^{58}$.

Em 1975, na Galeria Rudolf Zwirner, em Colônia, na Alemanha, Kounellis apresentou uma performance ${ }^{(\mathrm{v})}$ na qual dispôs sobre uma mesa fragmentos de estátuas acompanhados por um corvo empalhado e uma lamparina acessa. $\mathrm{O}$ artista permanecia junto à mesa, em silêncio, sentado numa cadeira ${ }^{(v)}$ e vestindo uma máscara ${ }^{(v)}$ que representava Apolo. O cabelo ${ }^{(v)}$ do artista estava amarrado a um vasto feixe de fios de cabelo que se estendia pelas paredes do espaço expositivo, criando uma imagem $^{(v)}$ que se assemelhava à fumaça ${ }^{(v)}$ que escapa de uma chaminéé ${ }^{(v)}$ (ver imagens 77 e 79). Nessa obra que Kounellis e Rudi Fuchs, em 1981, no catálogo da mostra realizada no Stedelijk Van Abbemuseum ${ }^{59}$, associaram à gravura $O$ sono da razão produz monstros, de Goya ${ }^{(v)}$, a mesa se converte em um altar que recebe como sacrifício ao deus Apolo o corpo esquartejado do próprio Apolo. Esse aparente pesadelo, segundo Marc Scheps, sinaliza "uma metáfora para a perda de uma unidade na qual apenas os fragmentos permanecem" ${ }^{\prime 0}\left[\right.$ ver fragmento $\left.{ }^{(\mathrm{v})}\right]$.

\section{Migração}

A ideia de migração contorna aspectos biográficos da vida de Kounellis, em especial, sua mudança de Atenas para Roma, em 1956, onde residiu até o final da vida. $\mathrm{O}$ conceito de migração, contudo, também delineia certos procedimentos de trabalho do artista, sendo recorrente tanto na obra plástica quanto na escrita, além de estar intimamente relacionado ao conceito de acumulação $^{(v)}$. Observando atentamente as exposições realizadas por Kounellis, podemos notar que determinadas peças feitas para responder situações espaciais específicas são reexibidas em novas exposições, todavia, sem emularem sua disposição no
63 Sem título, 1989. Chapas de ferro instaladas na janela. Foto: Claudio Abate. 


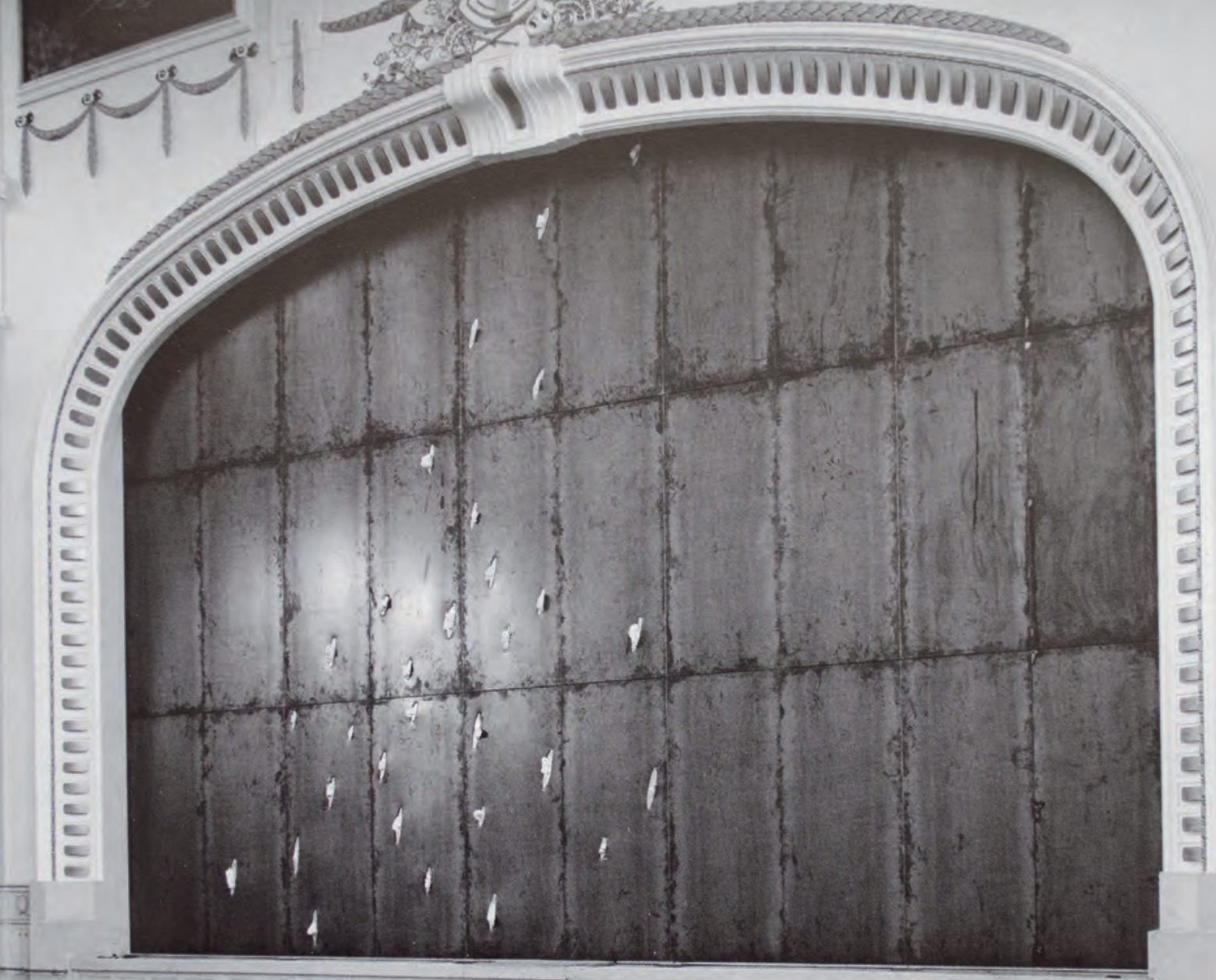


espaço expositivo $^{(v)}$ original. Essa é uma das camadas da ideia de migração presente na obra de Kounellis, em que determinadas peças se comportam como seres que respondem às novas qualidades espaciais presentes em cada novo espaço, como um migrante que se adapta à cultura de um novo país sem perder, no entanto, suas raízes, sua essência.

Outra camada da ideia de migração se relaciona ao conceito de viagem $^{(v)}$, tanto ao deslocamento físico quanto ao deslocamento simbólico pontuado na poética de Kounellis pelo labirinto ${ }^{(v)}$. Conforme já sinalizado, as obras de Kounellis realizam um deslocamento físico, exposição após exposição, ao passo que, no labirinto, é sugerido ao observador um deslocamento simbólico que remete aos ritos de iniciação mitológicos, que conferem ao iniciado o acesso a novos conhecimentos e experiências.

Moore, Henry (1898-1986)

Escultor britânico. Em 1940, Moore estava em Londres durante a Blitzkrieg da Luftwaffe e, como outros cidadãos britânicos, abrigou-se nos túneis do metrô londrino. Seu estúdio foi, inclusive, destruído pelos bombardeios. Posteriormente, Moore registrou essa experiência em desenhos feitos de memória - os desenhos de 1940-1941. Os trabalhos de performance $^{(v)}$ realizados por Kounellis nos anos 1970 (ver imagem 127) trazem a lembrança dos desenhos de Moore, bem como as peças das décadas de 2000 e 2010 nas quais o artista desenvolveu a imagem ${ }^{(v)}$ do esquife $^{(v)}$ (ver imagens 38, 39 e 125).

Munch, Edvard (1863-1944)

Pintor norueguês. Munch foi um artista que viveu o humor da passagem do século XIX para o XX. Em seu projeto mais ambicioso, o Friso da $v i d a^{61}$, é visível a tensão entre a expressão do indivíduo e a sociedade. Nos escritos de Munch posteriores à realização desse conjunto de pinturas, o artista reconhece e afirma seu projeto: "Leonardo da Vinci analisou os órgãos internos do corpo humano dissecando cadáveres - eu tento dissecar a alma" ${ }^{92}$.

Em 1980, na Galeria Mario Diacono, Kounellis exibiu um conjunto de desenhos cujas imagens assemelhavam-se às formas das figuras
64 Sem título, 1986. Chapas de metal com incrustações de chumbo e fragmentos de peças de gesso.

$600 \times 902 \mathrm{~cm}$. Exposição na Secessão Vienense, Viena, 1986. Foto: Claudio Abate.

65 Sem título, 1986. Chapas de metal com incrustações de chumbo e fragmentos de peças de gesso. $600 \times 902 \mathrm{~cm}$. Exposição fannis Kounellis, Galeria Nacional, Berlim, 2007. Foto: Manolis Baboussis.
61 Nome que Munch atribuiu em 1918 a um conjunto de pinturas em diferentes formatos produzidas entre $1890 \mathrm{e}$ 1900.

62 (MUNCH, 1909, p. 374). 


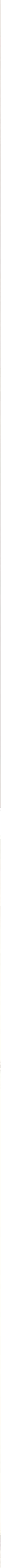


de Munch e cujas medidas se aproximavam das dimensões de uma porta $^{(v)}$ (ver imagens 33 e 182). Esse conjunto de desenhos dialoga com as paredes com pedra ${ }^{(v)}$ e com outros materiais que o artista vinha realizando desde 1972 (ver imagens 105, 186 e 188). Se, para Kounellis, essas paredes revelam a escala humana presente na arquitetura nas dimensões de uma porta, esses desenhos dialogam com o projeto de Munch no que diz respeito ao conhecimento da alma humana.

Em 1996, Kounellis publicou no catálogo da exposição Munch en na $M_{u n c b^{63}}$, realizada no mesmo ano no Stedelijk Museum, em Amsterdam, "Para Edvard Munch". No texto, Kounellis afirma que Munch e Van Gogh foram os dois artistas que estabeleceram novos paradigmas para a expressão da subjetividade [ver parede $\left.^{(v)}\right]$.

\section{Música}

Na década de 1970, Kounellis começou a produzir trabalhos com performance $^{(v)}$ em que a música era o elemento central. Nessas obras Kounellis contratava músicos profissionais para executar fragmentos selecionados de peças e óperas eruditas de compositores como: Giuseppe Verdi (ver imagem 47), Wolfgang Amadeus Mozart (ver imagens 75 e 78), Johann Sebastian Bach (ver imagem 127), Ígor Stravinsky (ver imagem 6), Antonín Dvořák (ver imagem 4), Gustav Mahler e Georges Bizet (ver imagem 92).

Nos trabalhos com fragmentos de Verdi, Mozart e Bizet, os músicos se posicionavam em uma pequena parcela do espaço de modo que o som, ao reverberar pela arquitetura, produzia uma ocupação sonora do espaço expositivo $^{(v)}$, antecipando a experiência auditiva do espectador em detrimento da visão. Nas obras com fragmentos de Bach e Stravinsky, Kounellis pintava sobre a tela a partitura ${ }^{(v)}$ que era executada pelo músico, ou seja, havia uma dupla "execução" da música: uma como fenômeno sonoro e outra enquanto anotação.

Ainda na década de 1970, Kounellis realizou obras nas quais os instrumentos musicais $^{(\mathrm{v})}$ e a partitura eram apresentados, mas não havia qualquer performance musical. Nessas peças, composições como Sinfonia No. 9 de Dvořák ou o "Adagietto" da Sinfonia No. 5 de Mahler eram reconhecidas por indicações de suas respectivas partituras [ver fragmento $^{(\mathrm{v})}$.
66 Sem título, 1986.

Chapas de metal com incrustações de chumbo e fragmentos de peças de gesso. $600 \times 902 \mathrm{~cm}$. Exposição fannis Kounellis: uma retrospectiva em cinco lugares, Museu de Arte Contemporânea de Chicago, Chicago, 1986. Foto: Claudio Abate.

67 Sem título, 1986. Chapas de metal com incrustações de chumbo e fragmentos de peças de gesso. $600 \times 902$ cm. Exposição fannis Kounellis: Via del Mare, Museu Stedelijk, Amsterdã, 1990-1991. Foto: Claudio Abate.
63 A exposição Munch en na Munch foi curada por Rudi Fuchs e combinava as obras de Munch com peças de artistas contemporâneos. Kounellis figurava entre os artistas que participaram da mostra. 


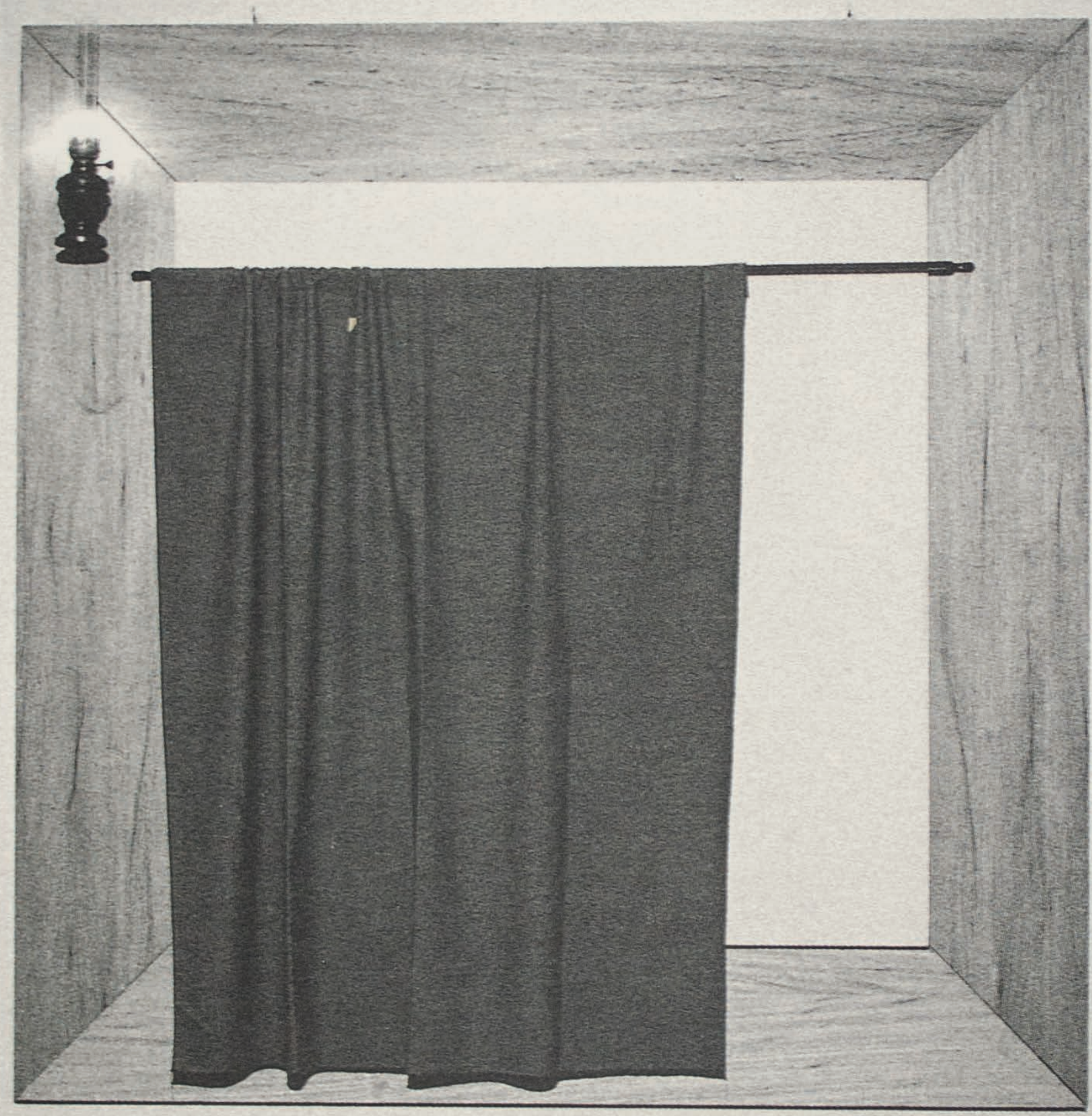


Em diferentes obras de Kounellis é recorrente o procedimento da repetição de elementos para a construção do trabalho, sendo a repetição por doze vezes de um mesmo elemento a mais perceptível. Ela ocorre na emblemática peça Sem título (Cavalo), de 1967, em que doze cavalos são dispostos no espaço expositivo ${ }^{(v)}$ (ver imagem 160), mas também em obras como Sem título, de 2006, em que doze cadeiras definem o perímetro $^{(v)}$ do espaço, que contém uma mancha ${ }^{(v)}$ de tinta feita por Kounellis (ver imagem 104), ou ainda as doze portas fechadas com diversos materiais na exposição realizada na Vijécnica, em Sarajevo (ver imagem 200). Outros números recorrentes que se referem à quantidade de repetições são: o três, o quatro e o sete.

Em diferentes culturas ocidentais os números três e quatro são considerados sagrados, assim como os números sete e doze, que são o resultado de suas somas e multiplicação, respectivamente. Em resumo, o três se refere às fases da existência: aparecimento, evolução e destruição, e, também, aos planos do mundo: céu, terra e inferno. O quatro se refere às direções cardeais, às estações do ano e ao quadrado ${ }^{(v)}$. O sete representa a totalidade do espaço e do tempo e é o número que representa Apolo. Já o doze é o número das divisões espaçotemporais e refere-se ao curso cíclico das coisas, como os doze meses do ano ou os doze pontos que marcam as horas num relógio.

\section{Odor}

Em diversas situações expositivas, Kounellis utilizou o odor do café (v) $^{(v)}$ da grapa $^{(v)}$ e do gás - usado para manter a chama do maçarico e, assim, inserir o fogo ${ }^{(v)}$ nas obras - para promover a antecipação ${ }^{(v)}$ do olfato em detrimento da visão (ver imagens 152, 32, 137 respectivamente). Porém, alguns animais usados pelo $\operatorname{artista}^{(v)}$, como o cavalo $^{(v)}$ e o papagaio $^{(v)}$, também possuíam cheiro perceptível, que poderia ser intensificado em função das condições de manutenção e circulação de ar do espaço expositivo ${ }^{(v)}$ (ver imagens 51 e 160). Nessas peças em que havia um estímulo ao olfato, o odor era um forte indicador da autenticidade do que estava sendo mostrado, na medida em que reiterava a apresentação ${ }^{(v)}$ dos materiais e/ou animais, transformando o observador em uma testemunha do fragmento ${ }^{(v)}$ de realidade ali presente. 



\section{Ouro}

O ouro é um material historicamente associado à representação do espaço sagrado, como ocorre nos ícones pintados por Andrei Rublev ${ }^{(v)}$, por exemplo. Em Sem título, de 1972, um par de sapatos infantis folheado a ouro é apresentado sobre uma estrutura ${ }^{(v)}$ de madeira que visualmente se assemelha à parte inferior de uma cruz (ver imagem 71). Nessa obra, Kounellis relacionou o uso do ouro a Andrea del Verrocchio (1435-1488) que, além de pintor e escultor, era ourives. A Kounellis interessava a capacidade de Verrochio em trabalhar com atenção os detalhes, o que, para ele, significava restaurar as particularidades e exemplificava uma fé na artesania ${ }^{64}$.

Três anos depois, na Galeria Lucio Amelio, em Nápoles, Kounellis expôs Sem título (Tragédia Civil), de 1975, obra na qual uma parede foi recoberta com folhas de ouro e a ela foi associado um porta-casacos com peças de vestuário ${ }^{(v) 65}$ (ver imagem 17). Nessa peça percebemos o estabelecimento da relação figura e fundo entre o porta-casacos e a parede. Em entrevista a Bruno Corà realizada em 1980, Kounellis, além de citar Verrocchio, relevou sobre o uso do ouro a influência de certas pinturas da Escola de Siena e da obra de Gustav Klimt ${ }^{(\mathrm{v}) 66}$.

Em Sem título (Tragédia Civil), como nas pinturas de Klimt e Rublev, uma figura está na frente do plano dourado, intermediando a relação do observador com o espaço. No entanto, na obra de Kounellis a figura corresponde às peças de vestuário ali penduradas, vinculando o corpo do observador ao trabalho. Pois, diferentemente da obra dos artistas supracitados, nas quais as figuras já estão determinadas, em Sem título (Tragédia Civil) Kounellis produz no espaço e em escala ${ }^{(v)}$ humana, a ser preenchido.

\section{Ovo}

O ovo é um objeto que simboliza o começo. Em 1969, em exposição realizada na Galeria Lucio Amelio, em Nápoles, Kounellis utilizou o ovo como sensibilidade ${ }^{(v)}$ e o associou a um painel de ferro ${ }^{(v)}$ com as dimensões de uma folha de papel Fabriano $^{(v)}$ (ver imagem 44). A obra, apesar de independente, se relaciona a outras três peças do artista presentes na mesma exposição, todas elas com chapas metálicas de dimensões idênticas à obra com o ovo. Na primeira, uma vela ilumina um breve texto escrito à mão que saúda Robespierre e Marat, figuras
69 Sem título, 1984.

Chapas de metal, cama de ferro, viga de ferro, prateleiras com madeira, fuligem e pedras enroladas em cobertor e quadrado preto. $200 \times 1080 \mathrm{~cm}$. Vista da exposição fannis Kounellis: uma retrospectiva em cinco lugares, Museu de Arte Contemporânea de Chicago, Chicago, 1986. Foto: Claudio Abate.

70 Sem título, 1984.

Maçarico, ferro, estrutura de cama, madeira e cinco prateleiras de metal com fuligem. $295 \times 665 \mathrm{~cm}$ Foto: Claudio Abate.

64 Ver Germano Celant, "L'Epos contemporânea", entrevista com Kounellis, de fevereiro-março de 1992, publicada em Kounellis, catálogo da exposição Padiglione d'Arte Contemporânea, em Milão, em 10 de abril a 31 de maio 1992, na página 28.

65 Existem várias versões da obra Sem título (Tragédia Civil). Na primeira versão de 1975, há também uma lamparina romana que ilumina a parede e o portacasacos. Na versão de 1986, o porta-casacos foi substituído por ganchos fixados na parede e a lamparina foi suprimida (ver imagens 17 e 59). 66 (KOUNELLIS, CODOGNATO, D'ARGENZIO, 2002, p. 178). 


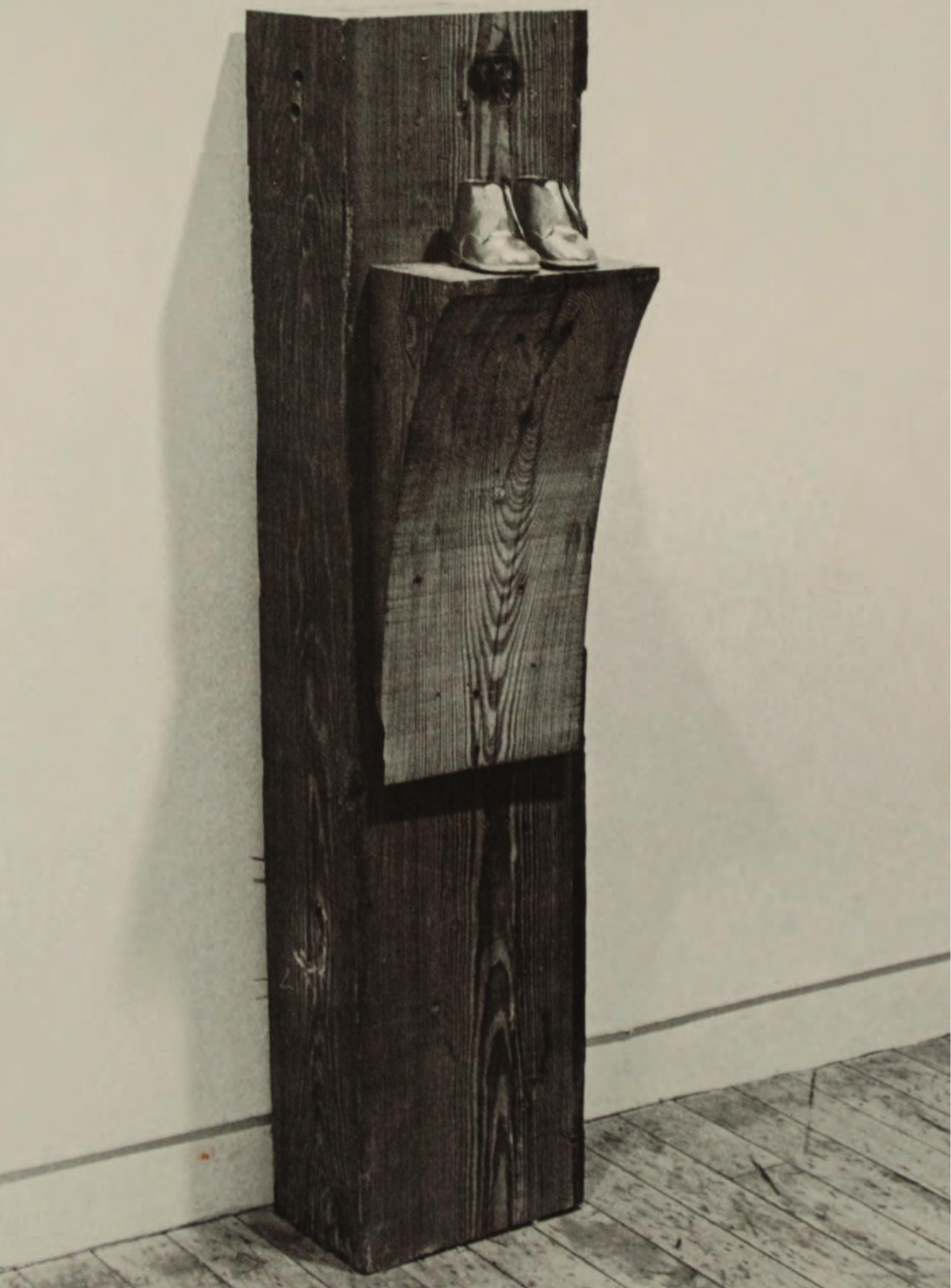


históricas da Revolução Francesa (ver imagem 15); a segunda apresenta uma trança de cabelo $^{(v)}$ humano (ver imagem 83); e, na última, quatro prateleiras de ferro fixadas na chapa metálica armazenam dezesseis pontos de fogo $^{(v)}$ (ver imagem 184). Esses quatro trabalhos reunidos constituem um ciclo, iniciado simbolicamente pela obra com o ovo, que alude à experiência histórica da Revolução.

Todavia, associo o ovo também às formas ovoides de Constantin Brancusi, em especial à obra O princípio do mundo, de 1920, e ao seu registro fotográfico realizado pelo próprio artista, que serve como introdução à leitura da peça. Para Rosalind Krauss, o "ovo" presente em O princípio do mundo é a "deflexão de uma geometria ideal", um objeto preexistente, pois trata-se de uma forma "dada a Brancusi e não por ele inventada" ${ }^{\prime 6}$, sendo o ato estético a transposição dessa forma para o contexto da arte. Logo, para Krauss, há um grau de ready-made nessa obra. Na análise de $O$ princípio do mundo e de sua respectiva imagem ${ }^{(v)}$ fotográfica feita por Brancusi, Victor Stoichita, embora não cite, realiza uma leitura formal similar à de Krauss, porém chega a outra conclusão. Para Stoichita, o "ovo" tanto na obra quanto na fotografia surge "miraculosamente do conflito entre luz e sombra"

Na obra de Kounellis de 1969, o ovo repousado no painel de metal é verdadeiro e essa característica o inscreve na história dos objetos readymade e trouvé. Entretanto, reiterando a análise inicialmente tecida, a sombra do ovo em oposição à superfície branca da casca parece aludir novamente a aspectos da Revolução Francesa, tanto ao Iluminismo, que a inspirou, quanto ao terror das execuções.

\section{Palavra}

Dentro do léxico poético de Kounellis a palavra foi utilizada ao menos de quatro formas distintas: a palavra pintada, a recitada, a cantada e a escrita. Com exceção da última, que se manifestou em textos produzidos no decorrer de toda sua carreira, todas as demais manifestações que envolvem a palavra foram, grosso modo, desenvolvidas entre as décadas de 1950 e 1970.

A palavra pintada surge nas primeiras experiências pictóricas de Kounellis entre os anos de 1950 e 1960 que apresentam palavras e signos gráficos que sugerem indicações espaciais e temporais (ver imagens 7, 8 e 129) organizadas conforme uma partitura ${ }^{(v)}$. Durante a realização
71 Sem título (Para Damiano Rousseau), 1972. Sapatos infantis pintados de ouro sobre viga de madeira. $125 \times 50 \times 25 \mathrm{~cm}$. Foto: Claudio Abate.
67 (KRAUSS, 1998, p. 105). 68 (KRAUSS, 1998, p. 108). 69 (STOICHITA, 2016, p. 200). 

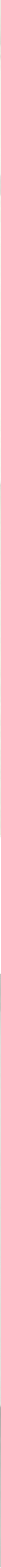
de algumas dessas obras, Kounellis começou a recitar cada uma das letras pintadas, criando um procedimento performático que evocava a performance $^{(\mathrm{v})}$ de Hugo Ball ${ }^{(\mathrm{v})}$ no Cabaré Voltaire (ver imagem 169).

Por fim, a palavra cantada se materializou através de cantores profissionais que executavam fragmentos de óperas, como Carmen, de Georges Bizet, em associação a outros elementos formais (ver imagem 92) [ver fragmento $\left.{ }^{(\mathrm{v})}\right]$.

\section{Papagaio}

O papagaio foi utilizado pela primeira vez, por Kounellis, na exposição de 1967, na Galeria L'Attico, em repouso sobre um poleiro instalado em uma chapa de aço com as dimensões de uma folha de papel Fabriano ${ }^{(v)}$ (ver imagem 51). O papagaio é um animal que não é capaz de representar ou atuar, apesar de ser capaz de emular certos sons da fala humana. Portanto, essa suposta possibilidade de "fala" está submetida a uma condição de repetição, em outras palavras, ele apenas vive.

Aqui, gostaria de pontuar que análise semelhante foi feita, anteriormente, por meio da justaposição de imagens proposta por Rudi Fuchs e Kounellis, em 1981, para o catálogo da mostra individual realizada no Stedelijk van Abbemuseum ${ }^{70}$. Na publicação são aproximadas a pintura de Courbet $^{(v)}$, Mulher com papagaio, e a peça Sem título (Papagaio).

\section{Partitura}

Uma das séries de pinturas produzidas por Kounellis nas décadas de 1950 e 1960 possuía uma dinâmica interna que compunha visualmente uma espécie de partitura para o observador (ver imagens 7, 8 e 129). Esse modelo de composição visual, para Stephen Bann, reaparece em obras realizadas sobre chapas de ferro ${ }^{(v)}$, nas quais os elementos associados à sensibilidade $^{(v)}$ são distribuídos sobre a superfície da estrutura $^{(v)}$ (ver imagens 10, 11 e 36). Vale lembrar que nos anos 1970 Kounellis produziu pinturas que exibiam fragmentos de pautas musicais e acompanhavam performances com dança e música ${ }^{(v)}$ (ver imagens 6 e 128) [ver performance ${ }^{(v)}$.
72 Sem título, 1985.

Chapas de metal, madeira e quadrado preto pintado. $200 \times 900 \mathrm{~cm}$. Foto: Claudio Abate.

73 Sem título, 1984. Chapas de metal, cama de ferro, viga de ferro, maçarico, prateleiras com madeira, fuligem e pedras enroladas em cobertor e quadrado preto. $200 \times 1080 \mathrm{~cm}$. Foto: Claudio Abate. 


\section{Pedra}

Dos monumentos pré-históricos à catedral ${ }^{(v)}$ - o "livro de pedra", segundo Victor Hugo -, a pedra é um elemento mineral cuja solidez e permanência se confundem com sua utilização no campo da arquitetura. Em 1991, para a exposição na Sinagoga de Stommeln, Kounellis fabricou três colunas de madeira e fixou no topo de cada uma delas uma pedra (ver imagem 142). As colunas feitas pelo artista não possuíam qualquer função estrutural em relação à arquitetura, elas apenas transmitem ao observador uma imagem $^{(v)}$ de maior estabilidade ao desenhar no espaço metade da Estrela de Davi, um símbolo-chave da cultura judaica. A pedra foi usada também para a oclusão de portas, criando paredes [ver coluna $^{(v)}$ e parede $^{(v)}$ e porta $\left.^{(v)}\right]$.

\section{Parede}

Eu construí muitas imagens com fogo e muitas com paredes. Paredes de pedra, madeira, troncos, livros, sacos. Uma parede coberta com folha de ouro. E minhas primeiras imagens com flechas e letras também eram paredes. Eles tinham as dimensões das paredes da minha casa e foram pintadas com tinta de parede. A tela encostou-se contra a parede, eu a removia e colocava outra. Tudo isso só para dizer que nunca pintei uma imagem sobre um cavalete. Em 1969, em San Benedetto del Tronto, eu emparedei uma porta com pedras simplesmente encaixadas. A cavidade da porta me permitiu construir essa imagem inteiramente de pedra. Não era uma oclusão, era uma imagem com as dimensões da porta. $\mathrm{O}$ meu problema não é o encerramento, mas sempre a revelação ${ }^{71}$.

A revelação que Kounellis atribuiu à criação de uma imagem ${ }^{(v)}$ com as dimensões da porta $^{(v)}$ só foi possível quando uma sensibilidade ${ }^{(v)}$, no caso a pedra ${ }^{(v)}$, foi disposta no nicho da porta, que corresponde à estrutura ${ }^{(v)}$, de modo a preencher o espaço "vazio" da porta, ${\text { evidenciando o } \text { perímetro }^{(\mathrm{v})} \text { da abertura dela e a escala }}^{(\mathrm{v})}$ do corpo ali presente (ver imagem 186).

\section{Peixe}

$\mathrm{Na}$ fauna de Kounellis o peixe foi possivelmente o animal mais dócil e frágil a articular o conceito de sensibilidade ${ }^{(v)}$. Por suas características, o peixe geralmente aparece em situações destinadas à contemplação ou
74 Sem título, 1972. Folhas de ouro moldadas na boca de Kounellis. Foto: Claudio Abate. 


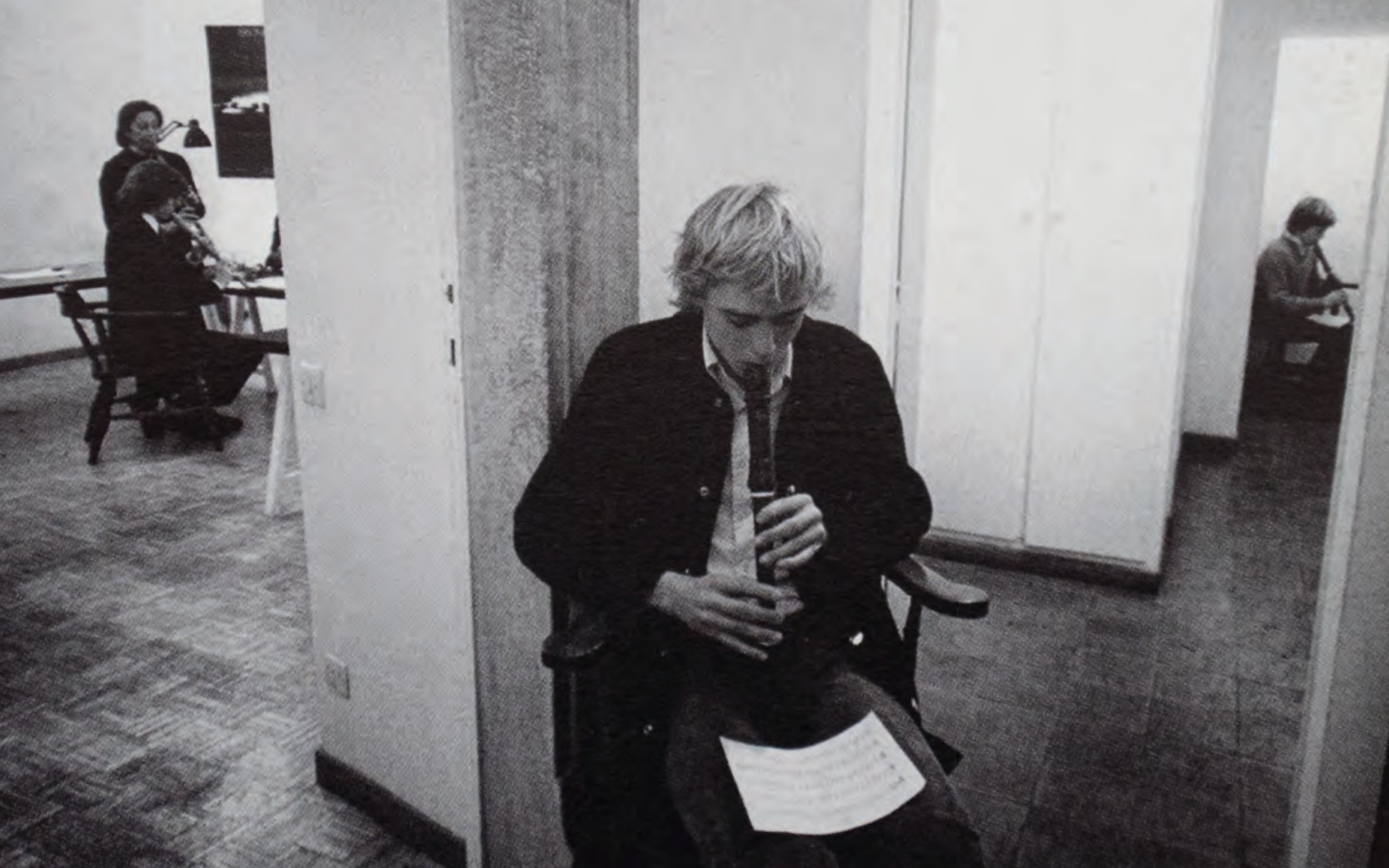


associado a um elemento de agressão como a faca ${ }^{(v)}$, vide a imagem ${ }^{(v)}$ usada como convite para a exposição na Sinagoga de Stommeln, em Pulheim, na Alemanha (ver imagem 145).

\section{Peso}

A ideia de peso na poética e nas obras de Kounellis se refere tanto à prática da mensuração, simbolicamente expressa no uso da balança ${ }^{(v)}$, quanto à lógica prático-teórica desenvolvida no interior da linguagem ${ }^{(v)}$ da pintura $^{(v)}$.

Masaccio $^{(v)}$ foi o primeiro artista a introduzir, no Renascimento, o conceito de peso ao sistema de representação pictórica. Essa inovação na linguagem instituiu um novo grau de qualidade para o fazer pictórico. A "boa pintura", segundo Giorgio Vasari, era aquela que exprimia também o peso daquilo que representava.

No Renascimento, a produção pictórica se materializava em afrescos, ou seja, essa produção pictórica passou a criar "pesos" em imagens que estavam diretamente relacionadas ao espaço arquitetônico. Tendo em vista "Pensamentos e observações sobre o corpo, sobre o comportamento, sobre o 'natural' e sobre o 'viver' como autenticidade teatral", "A terceira janela do segundo andar do Palazzo Farnese" e o documentário realizado na Fundação Arnaldo Pomodoro ${ }^{72}$, de Milão, em 2006, suponho que, para Kounellis, os afrescos polarizavam os espaços através do "peso" presente em suas imagens e que o valor do peso era uma qualidade moral que, para ele, deveria permanecer em suas obras enquanto um vínculo com a lógica da história da pintura.

\section{Performance}

Ao longo de sua carreira Kounellis concebeu diversas performances. Inicialmente, nos anos 1950 e 1960, elas eram protagonizadas exclusivamente pelo artista ou por seus materiais (ver imagens 45, 52 e 169). Na década seguinte musicistas e bailarinos profissionais são contratados por Kounellis para performar ações previamente orquestradas por ele. Quando o artista participa dessas performances, quase sempre o faz vestindo a máscara ${ }^{(v)}$ de Apolo (ver imagens 19, 77, 78, 79 e 106). Já entre os anos 1980 e 1990, Kounellis constrói um conjunto de máscaras a partir da obstrução de sua boca ${ }^{(v)}$ que é apresentado ao público por meio da imagem ${ }^{(v)}$ fotográfica (ver imagens
75 Sem título, 1971.

Flautistas executam

fragmentos de Mozart. Foto: Claudio Abate.

76 Sem título, 1973. Mesa com fragmentos de estátua de gesso e corvo empalhado. Foto: Claudio Abate.
72 Documentário de Ermanno Olmi realizado entre 28 de agosto e setembro de 2006 durante a montagem da exposição Jannis Kounellis: atto único. Disponível em: https://bit.ly/32egnPq. Acesso em: 2 fev. 2020. 


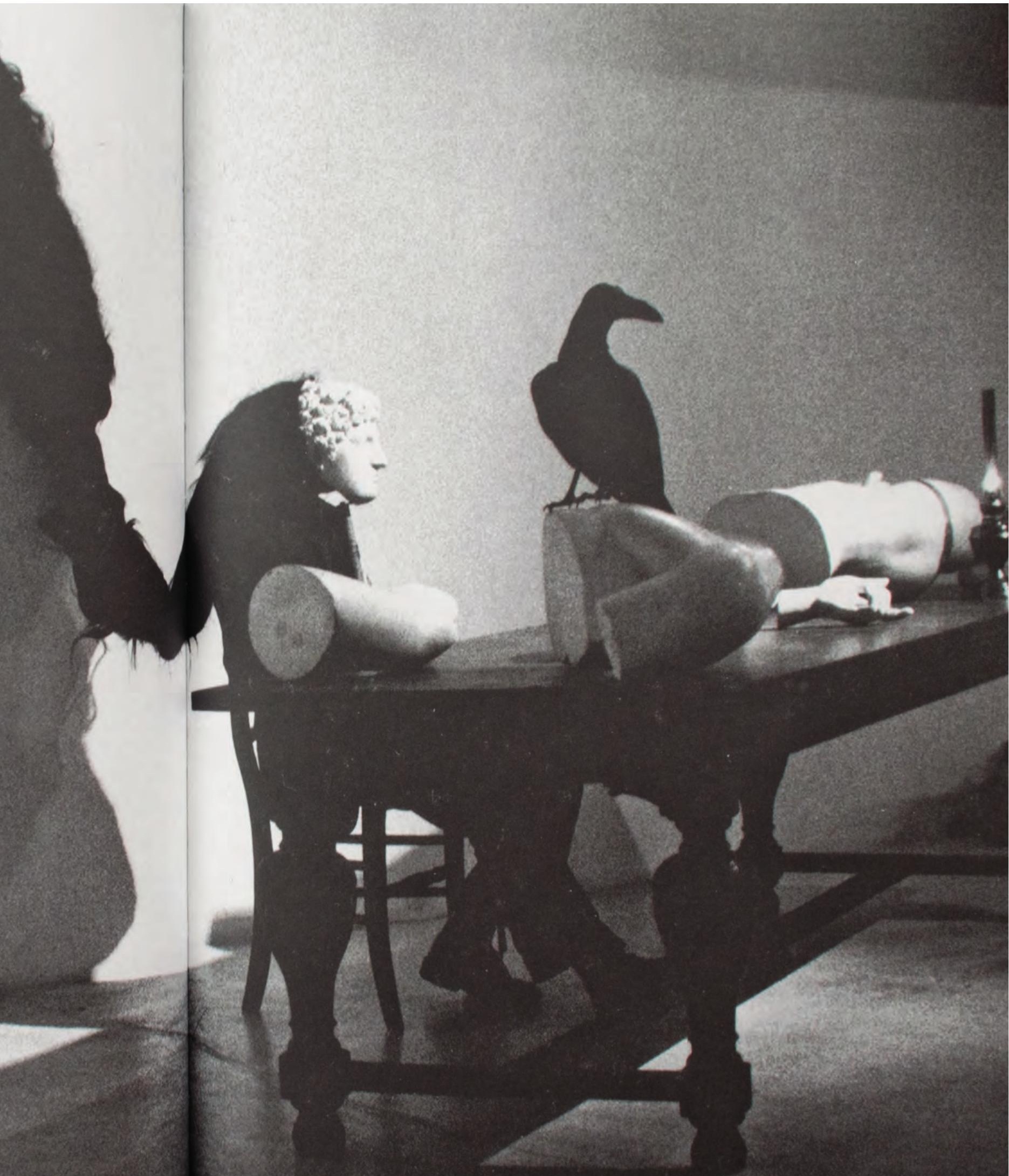


3, 149 e 185). Nos anos entre 2000 e 2010, Kounellis reapresentou várias performances com música ${ }^{(v)}$ da década de 1970, bem como exibiu obras feitas a partir de gestos em que a mancha ${ }^{(v)}$ de tinta era um recurso recorrentemente usado (ver imagens 98 e 104). Além disso, o artista, em diferentes ocasiões, repetiu determinados modelos de montagem já consolidados na memória do espectador no espaço expositivo(v), modificando apenas o material utilizado (ver imagens na sequência 49, 141, 160, 20, 137, 136, 110 e 111). Como se pode notar, no decorrer do tempo, o corpo do artista vai saindo de cena e desaparecendo gradativamente. Assim, o que permanece são indícios da presença de Kounellis e as imagens por ele criadas.

É importante salientar que as performances de Kounellis reorganizavam as experiências que o artista teve como cenógrafo de teatro ${ }^{(v)}$, em especial, no que concerne à duração da ação. Nas performances de Kounellis, a duração era dada, em geral, pela repetição de um único fragmento ${ }^{(v)}$, que variava sutilmente em função da interpretação dada pelo performer que a executava, lembrando que as performances com música tinham a partitura $^{(v)}$ como referência [ver litania $\left.{ }^{(v)}\right]$.

\section{Perímetro}

Para Kounellis o conceito de perímetro se refere tanto ao espaço expositivo $^{(v)}$ e ao suporte quanto à linguagem ${ }^{(v)}$ da pintura ${ }^{(v)}$. Portanto, quando afirma que nunca ultrapassou os limites ${ }^{73}$, o artista se reporta tanto aos limites físicos do espaço e do suporte quanto aos limites conceituais referentes à produção artística. $\mathrm{O}$ perímetro, em termos de linguagem, diz respeito ao emprego da técnica em concomitância com a teoria para o estabelecimento de uma efetiva relação entre a imagem $^{(v)}$ e o suporte. Em outras palavras, o perímetro, nessa acepção do termo, corresponde às ferramentas técnicas e conceituais necessárias para a produção artística. Enquanto limite físico, o espaço expositivo e o suporte correspondiam, para Kounellis, à lógica da estrutura ${ }^{(v)}$, pois, ao conterem a sensibilidade ${ }^{(\mathrm{v})}$, revelavam o seu perímetro e, consequentemente, o contexto.

Picasso, Pablo (1881-1973)

Artista espanhol. Kounellis era um admirador da obra do pintor, em espacial das pinturas Les demoiselles d'Avignon (1907) e Guernica (1937)
77 Detalhe de Serm título, 1975. Mesa, cadeira,

Kounellis com a máscara de Apolo amarrada em

feixe de cabelos humanos, fragmentos de estátua de gesso, corvo empalhado e lamparina. Foto: Claudio Abate. 
que, para ele, demonstravam o comprometimento de Picasso com a arte, bem como sinalizavam um importante desenvolvimento da linguagem ${ }^{(v)}$ da pintura ${ }^{(v)}$, sendo Guernica, inclusive, um exemplo daquilo que Kounellis definiu como declaração ${ }^{(v)}$. Em ao menos duas publicações ${ }^{74}$, Rudi Fuchs, Germano Celant e Kounellis associaram Les demoiselles d'Avignon à obra Sem título (Cavalo) (ver imagem 160), buscando explicitar a radicalidade formal presente em ambas. Já a obra realizada no Espai Poblenou, em Barcelona, apresenta uma nítida evocação da imagem ${ }^{(v)}$ de Guernica com seus pedaços de carne $^{(\mathrm{v})}$ iluminados por lamparinas (ver imagem 154).

Outro possível interesse de Kounellis em relação à obra de Picasso diz respeito à colagem enquanto um procedimento de reorganização e criação a partir do fragmento ${ }^{(v)}$, o que aparece esboçado em "Eu estava procurando a cabeça de Safo". Contudo, localizo Picasso na obra de Kounellis, também, na série de performances com música ${ }^{(v)}$ realizada na década de 1970 (ver imagem 75). Nessas ações a presença dos músicos, dos instrumentos musicais ${ }^{(v)}$, da mesa ${ }^{(v)}$ e o uso da máscara ${ }^{(v)}$ remetem a duas pinturas de Picasso feitas em 1921 e ambas intituladas Os três músicos.

\section{Pintor}

Eu fui chamado de artista nos anos sessenta porque eles não sabiam como definir uma pilha de carvão. Mas eu sou pintor, e afirmo minha iniciação na pintura. Porque a pintura é a construção de imagens e não indica uma maneira ou, e menos ainda, uma técnica. Cada pintor tem suas próprias visões e seus meios de construir imagens, e a linguagem que associa a palavra pintor à arte tradicional e a palavra artista ao papel de anarquista, modernista, experimental, é ridícula.

Jackson Pollock foi um pintor que reinventou epicamente o espaço americano. Os murales mexicanos estão pintados, todavia Duchamp também é pintor. O liberalismo concedeu a pintura uma liberdade chegando aos limites do imaginário e restaurou completamente o papel do intelectual para o $\operatorname{artista}^{75}$.

Para Kounellis a pintura ${ }^{(v)}$ era uma lógica cuja linguagem ${ }^{(v)}$, técnicas e teorias eram protegidas e expandidas pelo $\operatorname{artista}^{(v)}, o$ guardião $^{(v)}$ exclusivo desse conhecimento. Nos anos 1970, quando os debates em torno do fim da pintura buscaram colocar o artista em suas primeiras
78 Sem título, 1973. Mesa, fragmentos de estátua de gesso, corvo empalhado, flautista executando fragmentos de Mozart e Kounellis com a máscara de Apolo. Foto: Claudio Abate.

79 Sem título, 1975-1981. Mesa com fragmentos de estátua de gesso e máscara de Apolo com feixe de fios de cabelo humano. Foto: Claudio Abate. 


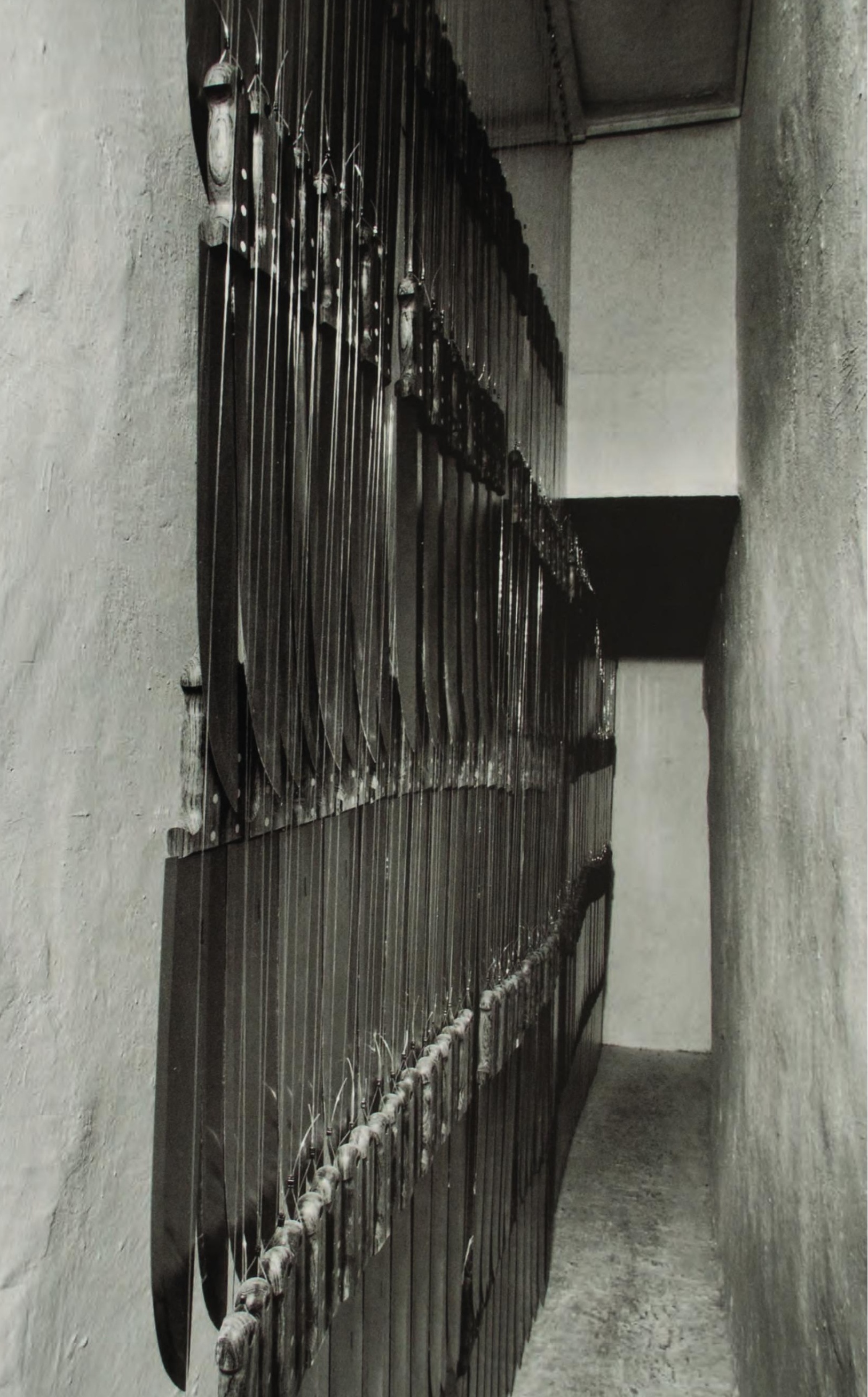


fileiras, Kounellis passou a definir-se como pintor, declarando que sua produção plástica era uma continuação do desenvolvimento de uma concepção pictórica fundamentada nos conceitos de acumulação(v), $\operatorname{apresentação~}^{(\mathrm{v})}$, cavidade teatral $^{(\mathrm{v})}$, estrutura $^{(\mathrm{v})}$ e sensibilidade $^{(\mathrm{v})}$.

\section{Pintura}

Para mim a pintura é uma lógica, na Idade Média eram pessoas que pintavam afrescos, mas depois de Masaccio a pintura é claramente uma lógica. Antes se

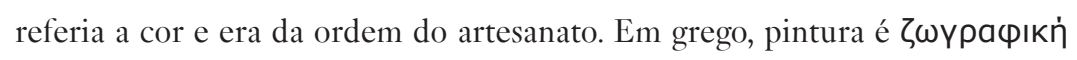
(zografikî) o que significa "desenho de vida" e isso não é uma ideia artesanal de pintura ${ }^{76}$.

No relato mitológico de Plínio, o Velho, sobre o surgimento da pintura, em História Natural, uma jovem desenha, na parede ${ }^{(v)}$, o contorno da sombra de seu amado ali projetada ${ }^{77}$. Esse gesto baseado na tentativa de fixar a presença parece exemplificar o que seria um "desenho de vida", além de apontar para outra formulação teórica associada à construção pictórica de Kounellis: a escala ${ }^{(v)}$ humana.

Por essa leitura, o desenho do contorno da sombra sobre a parede estabelece a escala pictórica em função das dimensões humanas e apresenta o problema da pintura para além de suas questões técnicas. Trata-se, inclusive, de um problema teórico sobre a concepção de algo capaz de reter, em algum grau, a experiência da vida, o que Kounellis, em sua poética, buscou apresentar através da relação entre os conceitos de estrutura $^{(v)}$ e sensibilidade ${ }^{(v)}$.

Em síntese, a ideia de "desenho de vida" afirma a linguagem ${ }^{(v)}$ da pintura dentro de uma lógica na qual técnica e teórica estão mutuamente imbricadas. Cabe lembrar que a produção artística de Kounellis foi comumente associada, a partir da década de 1970, à narrativa em torno do fim da pintura, sendo esse discurso um nítido desdobramento da teoria greenberguiana. O artista, por sua vez, discordou de tal vinculação e, para explicitar o quanto sua ideia de pintura destoava da formulação da crítica de arte, desenvolveu conceitos como cavidade teatral $^{(\mathrm{v})}$, acumulação $^{(\mathrm{v})}, \operatorname{apresentação~}^{(\mathrm{v})}$, estrutura $^{(\mathrm{v})}$ e sensibilidade $^{(v)}$.
80 Sem título, 2005. Cortina 
Arquiteto, gravador e pintor italiano. A obra de Piranesi acompanhou "a onda de curiosidade arqueológica que cresceu rapidamente com a redescoberta e a escavação, a partir de 1748, da antiga cidade romana de Pompéia, soterrada por uma explosão vulcânica em $79^{\text {”78 }}$. Piranesi

tem formação vedutista canalettiana; mas prefere a gravura à pintura. É arquiteto; mas constrói uma única igreja, pequena e estupenda, Santa Maria del Priorato. Não obstante, retrata em gravura os monumentos antigos, documenta com admirável exatidão os achados de Herculano, teoriza e polemiza sobre arquitetura ${ }^{79}$.

Kounellis cita Piranesi em "O julgamento de K." ao enunciar o projeto de trazer para o primeiro plano, sem alterar as escalas, o "homenzinho das ruínas de Piranesi”. As imagens referenciadas por Kounellis nesse texto fazem parte da série Magnificência e arquitetura dos romanos (1761) e são, em sua maioria, dedicadas às ruínas de Roma. Nas gravuras de Piranesi, fica evidente o caráter monumental das construções romanas, cuja escala $^{(v)}$ é atribuída pelo homenzinho que as descobre, como se, filosoficamente, a medida das coisas fosse dada pelo humano, o que remete ao humanismo ${ }^{(v)}$.

Nesse sentido, a proposição de Kounellis do "homenzinho de Piranesi" reitera o compromisso de uma mensuração do mundo pela "régua da escala humana", procedimento similar ao de eleger a cama ${ }^{(v)}$, a cadeira $^{(\mathrm{v})}$, a porta $^{(\mathrm{v})}$, o vestuário ${ }^{(\mathrm{v})}$ e outros objetos cujas dimensões são dadas a partir da escala humana.

Plantas (cactos)

Os cactos são elementos vivos dentro da obra de Kounellis que se relacionam ao conceito de sensibilidade ${ }^{(v)}$ e, ao serem contidos por objetos e formas conceitualizadas como estrutura ${ }^{(v)}$, enunciam a passagem da paisagem natural para a paisagem construída. A ideia de uma paisagem construída remete aos debates em torno do gênero pictórico da paisagem e atenta para o jardim como um desdobramento desse gênero ${ }^{80}$. Os cactos foram usados em Kounellis pela primeira vez em 1967, em exposição na Galeria L'Attico, na obra Sem título (Campo), um jardim de cactos plantado em uma estrutura de ferro ${ }^{(v)}$ (ver imagens 
$24 \frac{3}{9}$

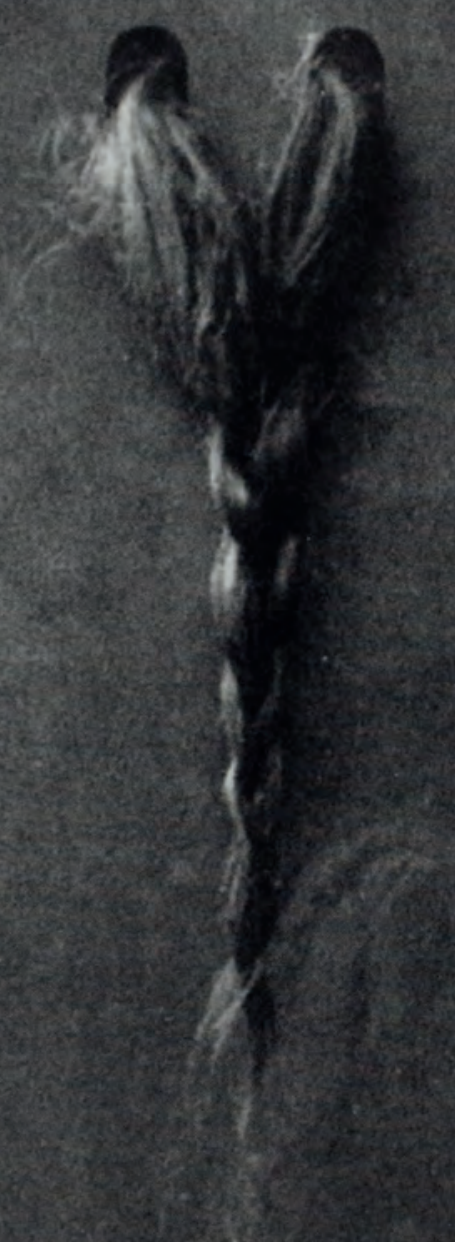


Pintor norte-americano. Allan Kaprow descreve, em "O legado de Jackson Pollock", de 1958, como o processo de trabalho e a linguagem ${ }^{(v)}$ pictórica de Pollock reverberaram - e reverberariam -, na produção das novas gerações de artistas. Kounellis que iniciou seus estudos em arte no ano 1956, ano da morte de Pollock, faria parte de uma geração de artistas italianos que em 1967 teria sua produção nomeada por Germano Celant como Arte Povera ${ }^{(v)}$.

$\mathrm{Na}$ produção inicial de Kounellis e nas pinturas produzidas sobre tela entre 1958 e 1967 (ver imagens 7, 8 e 129), já é possível vislumbrar o interesse do artista pelo processo de trabalho de Pollock. A feitura dessas pinturas não ocorria sobre um cavalete, mas em telas esticadas diretamente na parede do ateliê do artista, tal como Pollock fazia:

Minha pintura não vem do cavalete. Eu raramente estico a tela no chassi antes de pintar. Prefiro fixar a tela diretamente na parede ou no chão. Preciso da resistência de uma superfície dura. Com a tela no chão, sinto-me mais à vontade. Sinto-me mais próximo da pintura, tenho a impressão de fazer parte dela, pois posso movimentar-me à sua volta, trabalhar nos quatro lados da tela, estar literalmente dentro da pintura. É um método parecido com o dos pintores índios que trabalhavam sobre areia ${ }^{81}$.

Em "As palavras que me explicam", escrito em 1996, Kounellis manteve sua aproximação com Pollock quando afirmou que nunca pintou sobre um cavalete. Inclusive, nesse mesmo texto, declarou que Pollock reinventou o espaço americano.

Tendo em vista as pinturas e os escritos de Pollock e os textos de Kaprow e Kounellis, constato uma tensão dramática no processo de trabalho de Pollock, cujo desfecho seria a criação de uma espacialidade pictórica total na qual não existem hierarquias de valores em termos de composição. A técnica de produção sobre uma superfície rígida ajuda a fundamentar conceitualmente uma nova concepção de pintura $^{(v)}$ que permite ao artista trabalhar todos os lados da pintura e, igualmente, dentro dela. Pollock adentrou o perímetro $^{(\mathrm{v})}$ da pintura e, no interior da pintura, precisou se delimitar para se identificar como pintor. Eram os pés do artista que tocavam a tela, as mãos com pincéis e bastões que "gotejavam" a tinta sobre a superfície e que raramente encostavam nela. Em outras palavras, Pollock estava no interior da tela, muito próximo de se juntar à pintura, o que impedia esse ato era a distância percorrida pela tinta durante o dripping. 


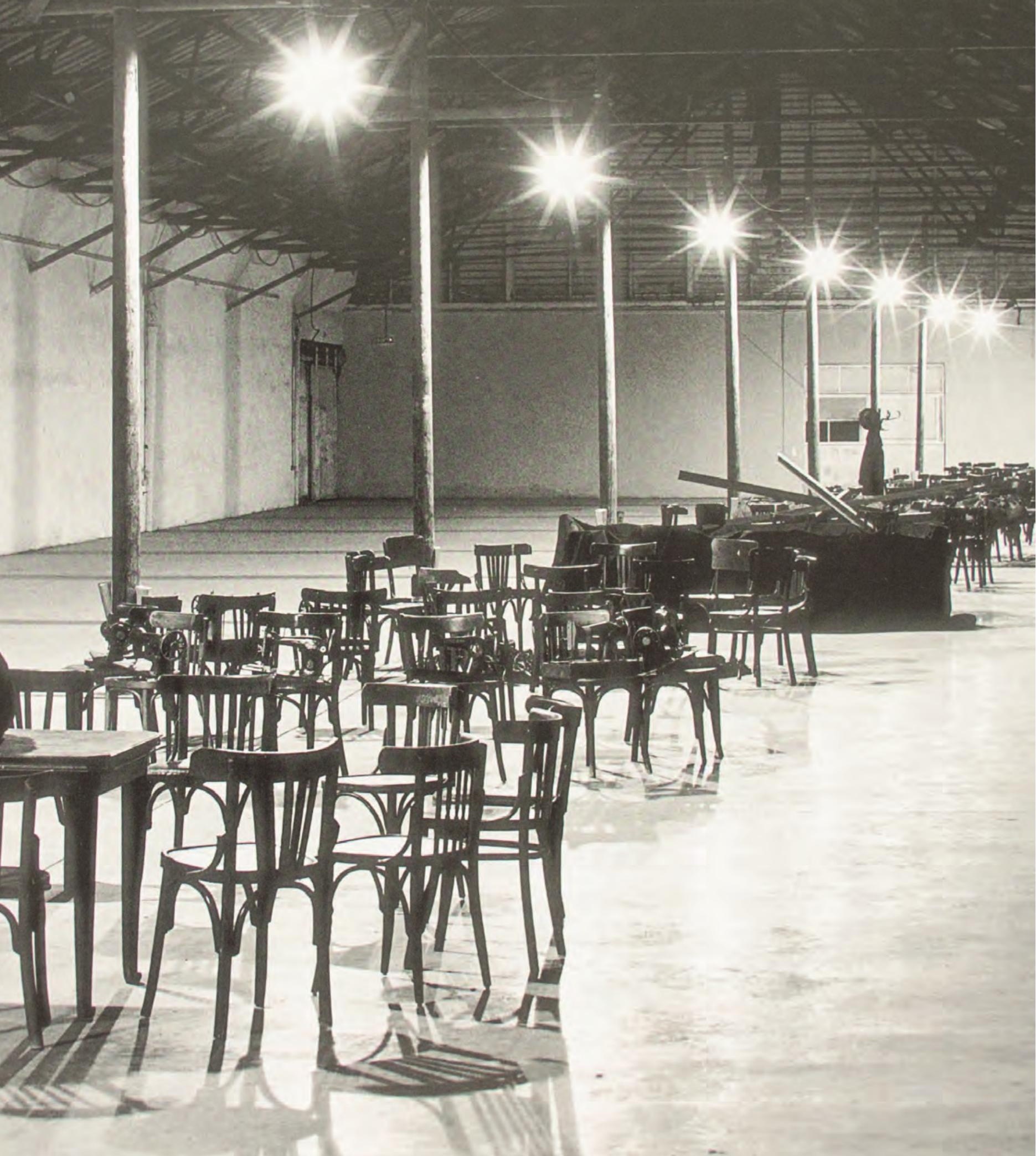


Por conta disso, acredito que, para Kounellis, Pollock estabelece o espaço da tela como espaço de ação, o que, por sua vez, gera uma ponte para a teatralidade da pintura italiana de Caravaggio $^{(\mathrm{v})}$.
84 Vista da exposição Kounellis - Porto de Faffa. Hangar principal, Jaffa, 2007. Foto: Manolis Baboussis.

\section{Porta}

A porta é um elemento arquitetônico que possui dimensões humanas, "porque as pessoas passam por ela" ${ }^{82}$. Kounellis, desde 1969, utilizou nichos de portas para a construção de trabalhos que, num primeiro momento, se apresentam como paredes que bloqueiam a passagem. No entanto, em um exame mais minucioso da escolha dos materiais utilizados por Kounellis para fechar os nichos, fica nítido que o artista não compreendia a porta apenas como local de circulação. Para Kounellis, a porta era um "molde" da escala ${ }^{(v)}$ humana que ele preenchia com objetos associados ao conceito de sensibilidade ${ }^{(v)}$ (ver imagens 105, 186 e 188). Esse gesto, para o artista, revelava o perímetro $^{(v)}$ do nicho da porta e, consequentemente, suas dimensões, criando uma imagem $^{(\mathrm{v})}$ em escala [ver parede $^{(\mathrm{v})}$ ].

\section{Prateleira}

A prateleira é um elemento de armazenamento e exibição que complementa a ideia de fragmento $^{(\mathrm{v})}$. Nas prateleiras são apresentadas partes de objetos ou resquícios de processos de queima, que são organizados segundo a lógica interna de cada trabalho (ver imagens 26, $27,46,69,70,71,72,73,161$ e 197). As prateleiras, feitas em ferro ${ }^{(v)}$, se relacionam ao conceito de estrutura ${ }^{(v)}$.

\section{Professor}

Entre 1993 e 2001, Kounellis dedicou-se à atividade docente na Academia de Artes de Düsseldorf, assumindo a cátedra anteriormente ocupada por Joseph Beuys. Em "Para meus alunos em Düsseldorf" e em entrevista a Catherine Hürzeler ${ }^{83}$, descreveu o que para ele era o desafio da atividade docente em artes.

Nesse contexto, o professor-artista traçou um breve paralelo entre a relação estudante-professor e a obra teatral A classe morta, de Tadeusz Kantor. Nessa encenação em especial, Kantor mantém-se em cena 


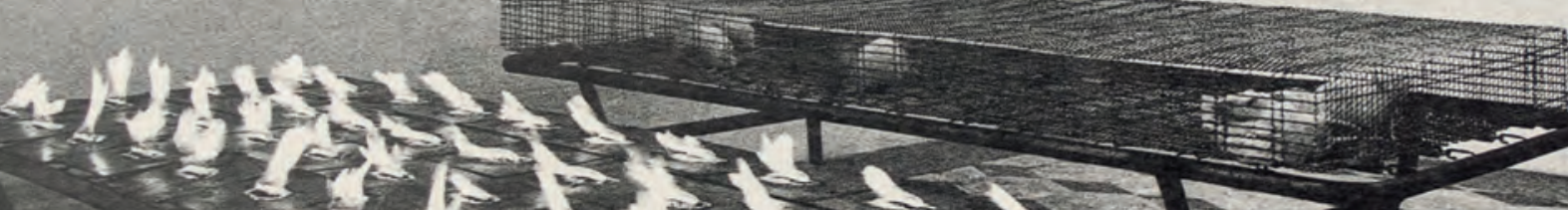
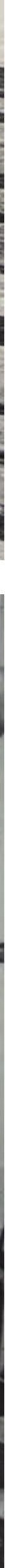
ocupando o papel ambíguo de professor e diretor, o que revela a estrutura $^{(v)}$ de funcionamento e a hierarquia de uma peça de teatro ${ }^{(v)}$. É importante destacar que Kantor compreendia o texto como um objeto ready-made, pois, para ele, existia uma ação do texto e uma ação da cena. Nesse sentido, os atores não representam o texto, mas "interpretam com" o texto ${ }^{84}$.

Transpondo esse entendimento para a sala de aula, suponho que Kounellis vislumbrava o estabelecimento de um espaço onde o estudante compreendesse que os conteúdos e materiais são objetos que possuem uma história e que a atividade do professor é propor métodos de abordagem e ligações entre eles, sem ocultar suas predileções. A sala de aula é concebida como um espaço onde os limites da estrutura de ensino são revelados em busca da formação de uma linguagem ${ }^{(v)}$ comum a todos, mas que também mantenha e fortaleça "sotaques" pessoais [ver acumulação $^{(\mathrm{v})}$, catedral $^{(\mathrm{v})}$, centralidade $^{(\mathrm{v})}$ e verticalidade $\left.^{(\mathrm{v})}\right]$.

\section{Quadrado}

O quadrado é uma forma geométrica que se reporta ao número quatro. O quadrado simbolicamente expressa a solidez, a tangibilidade e o sensível ${ }^{85}$. Em geral, Kounellis utilizou o quadrado, em textos e trabalhos, para aludir à obra de Malevich ${ }^{(v)} \mathrm{e}$, consequentemente, para evocar a concepção de pintura ${ }^{(v)}$ desse artista (ver imagens 58, 60, 62, 68, 72 e 73 [ver números ${ }^{(\mathrm{v})}$.

Rublev, Andrei (1360-1430)

Pintor russo de ícones. Kounellis dedicou a retrospectiva de 1981, realizada no Stedelijk van Abbemuseum, em Eindhoven, a Rublev, que foi um dos artistas que mais desenvolveu o sistema de representação da perspectiva inversa. Historicamente, a perspectiva inversa foi desenvolvida, na Rússia, em simultâneo à perspectiva italiana renascentista. Ambas serviram à representação religiosa cristã, porém enquanto a técnica da perspectiva inversa estava associada à representação segundo os dogmas da igreja ortodoxa, a igreja católica utilizou e ajudou a consolidar o sistema da perspectiva italiana.

Na perspectiva inversa, ao contrário da italiana, as figuras tendem a projetar-se e avançar do primeiro plano para o espaço, ou seja,
85 Sem título, 1969. Gaiola com ratos vivos sobre estrutura de cama e chapas de metal com fogo sobre estrutura de cama. Foto: Claudio Abate.

86 Vista do ateliê de Kounellis, c. 1970. Foto: Claudio Abate. 


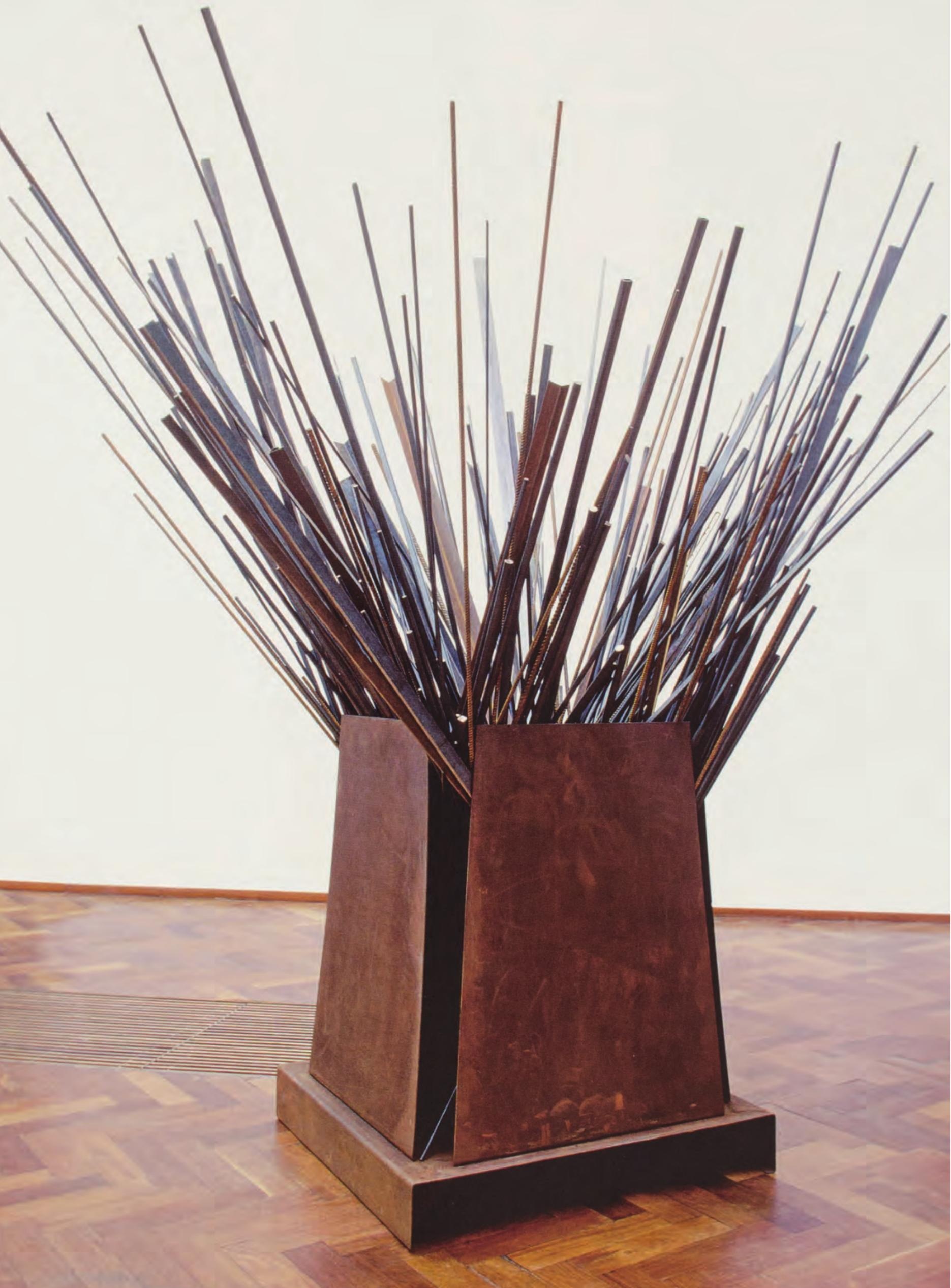


a perspectiva inversa não desenvolve a espacialidade da janela renascentista. Nesse sistema, simbolicamente, a figura religiosa está no limite entre o espaço sagrado, descrito pelo fundo em ouro ${ }^{(v)}$, e os fiéis (na posição do observador), de modo que o caminho para acessar o divino é mediado por essa figura.

Creio que Kounellis se interessou por Rublev por conta da lógica entre primeiro e segundo plano presente na perspectiva inversa, a qual é próxima das pinturas realizadas pela Escola de Siena e por Gustav Klimt $^{(v)}$, duas das referências utilizadas por Kounellis para comentar obras feitas com ouro como Sem título (Tragédia Civil), por exemplo (ver imagens 17 e 59).

\section{Saco de juta}

O saco de juta é um elemento que visualmente remete às pinturas de Burri $^{(v)}$ quando disposto sobre chapas de ferro ${ }^{(v)}$ ou em estruturas metálicas, articulando o conceito de sensibilidade ${ }^{(v)}$. No entanto, o saco de juta foi também o objeto que Kounellis utilizou para conter outros materiais, como cabelo ${ }^{(v)}$ e carvão(v) ${ }^{(v)}$ Essa escolha formal faz com que ele se associe ao conceito de estrutura ${ }^{(v)}$ (ver imagens 10, 11, 27, 34, 81, $93,121,165,166$ e 192).

\section{Schwitters, Kurt (1887-1948)}

Artista alemão. Kounellis citou Schwitters para desenvolver a ideia de fragmento $^{(v)}$, dado que processo de trabalho de Schwitters baseou-se, essencialmente, na lógica da colagem para criar obras bidimensionais e tridimensionais que o artista designou como objetos merz, sendo a Merzbau - cuja primeira versão foi realizada em 1923 na cidade de Hanover, na Alemanha, e que foi destruída em 1943 por um bombardeio dos Aliados durante a Segunda Guerra Mundial - sua obra mais relevante.

A Merzbau era um apartamento cujo interior era uma grande colagem de fragmentos diversos recolhidos e organizados por Schwitters. A obra é contemporânea do Proun room e do The abstract cabinet: demonstration room, ambos de El Lissitzky. Essas obras apontavam para uma organização racional do espaço e esvaziavam o caráter ritualístico do trabalho de arte. Schwitters manteve contato muito próximo com El Lissitzky, o qual, assim como ele, estava interessado em transformar seus
87 Sem título, 1996.

Estrutura de ferro e peças de ferro. $290 \times 306 \times 293 \mathrm{~cm}$. Foto: Aurelio Amendola. 

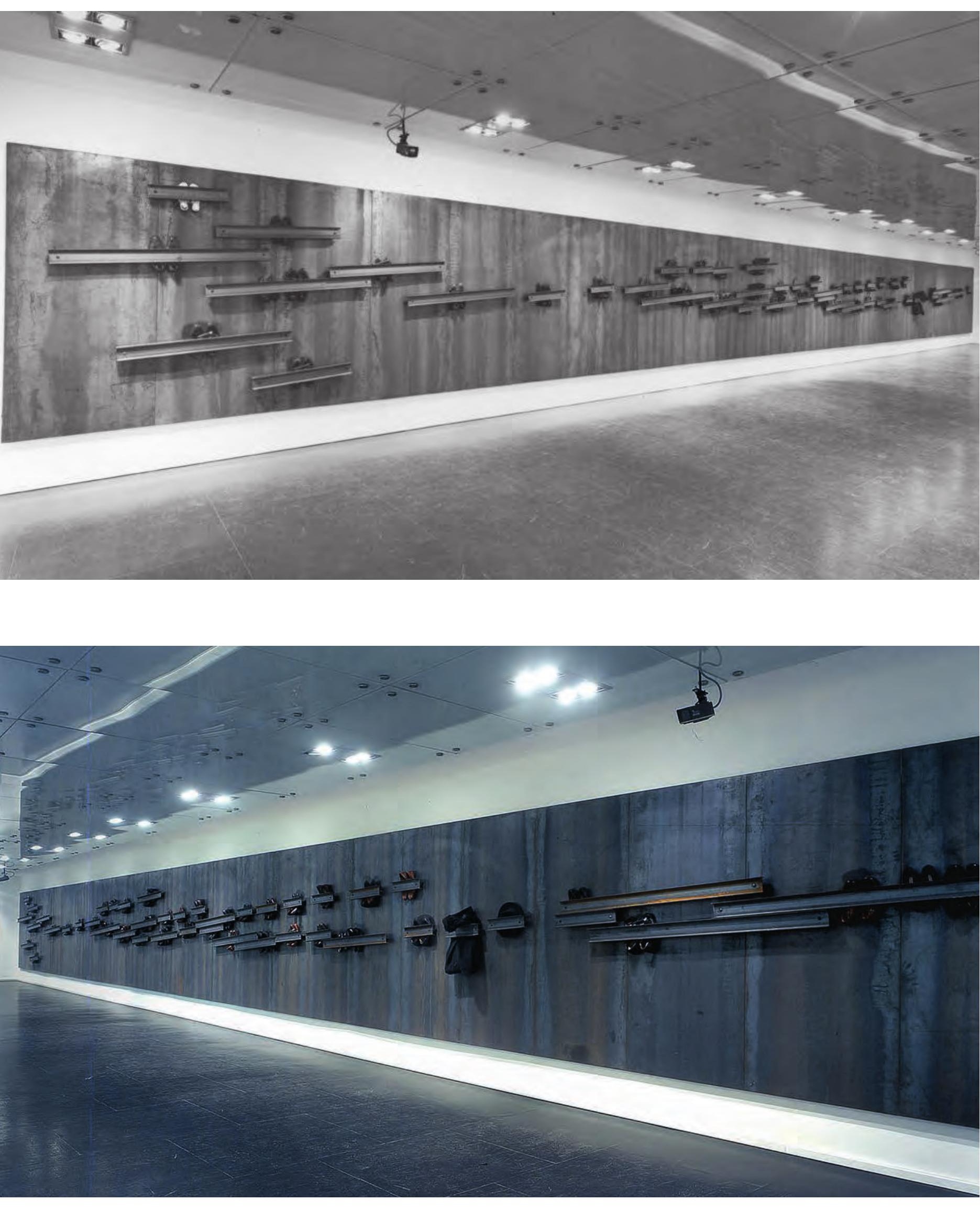


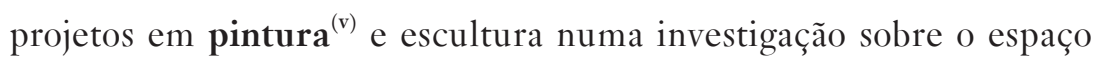
arquitetônico.

Contudo, a Merzbau era uma construção que reconsiderava o espaço ritualístico, onde as obras eram pensadas em conjunto, potencializando-se mutuamente. $\mathrm{O}$ espaço proposto por Schwitters intensificava a experiência sensorial para além do visual, o que também recuperava a ideia da catedral $^{(\mathrm{v})}$.

\section{Sem título}

Uma parcela expressiva das obras de Kounellis foi intitulada pelo artista de "sem título". Essa opção impossibilita o estabelecimento de um jogo linguístico entre a obra plástica - suas matérias, formas e significados - e o texto que compõe o título. Por outro lado, "sem título" preserva na produção de Kounellis um aspecto de continuidade que reitera a ideia de acumulação ${ }^{(v)}$, permitindo que as obras se articulem enquanto fragmentos e imagens que podem ser reordenados e ressignificados a cada nova exposição ou catálogo [ver fragmento ${ }^{(v)}$ imagem $^{(v)}$ e litania $^{(v)}$ ].

\section{Sensibilidade}

O conceito de sensibilidade formulado por Kounellis estava intimamente ligado ao conceito de estrutura ${ }^{(v)}$ por meio da relação entre conteúdo e continente, respectivamente. A sensibilidade se refere a um vasto léxico de materiais, sensações, objetos e seres utilizados pelo artista que aludem a alguma instância da vida. O conceito se manifesta por meio da presença de: seres vivos (pessoas, plantas e animais), materiais em estado quase bruto (algodão ${ }^{(v)}$ e café( ${ }^{(v)}$, por exemplo), objetos manufaturados (vela, livro ${ }^{(v)}$ e máquina de $\operatorname{costura}^{(v)}$, por

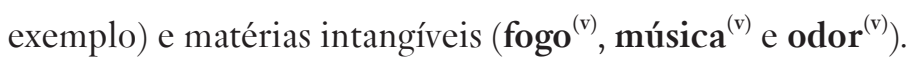

Historicamente, nas décadas de 1960 e 1970, enquanto uma parcela significativa dos artistas e teóricos da arte especulava a respeito do fim da pintura $^{(v)}$, Kounellis formulou os conceitos de estrutura e sensibilidade, sendo estes contemporâneos do livro Théorie du nuage, de Hubert Damisch. Para ser mais preciso, o livro de Damisch foi publicado, em francês, em junho de 1972; e, em agosto do mesmo ano, foi publicada a entrevista de Kounellis e Willoughby Sharp na revista Avalanche $^{86}$, na qual o artista relaciona seus conceitos às peças produzidas em 1967.
88 Sem título, 2001. Chapas de aço, vigas, sapatos,

sobretudo, chapéu, trens de brinquedo. Foto: Manolis Baboussis.

89 Sem título, 2001. Chapas de aço, vigas, sapatos,

sobretudo, chapéu, trens de brinquedo. Foto: Manolis Baboussis.
86 Ver Stiles e Selz (1996, p. 775-779) ou Kounellis, Codognato e D'Argenzio (2002, p. 140-151). 


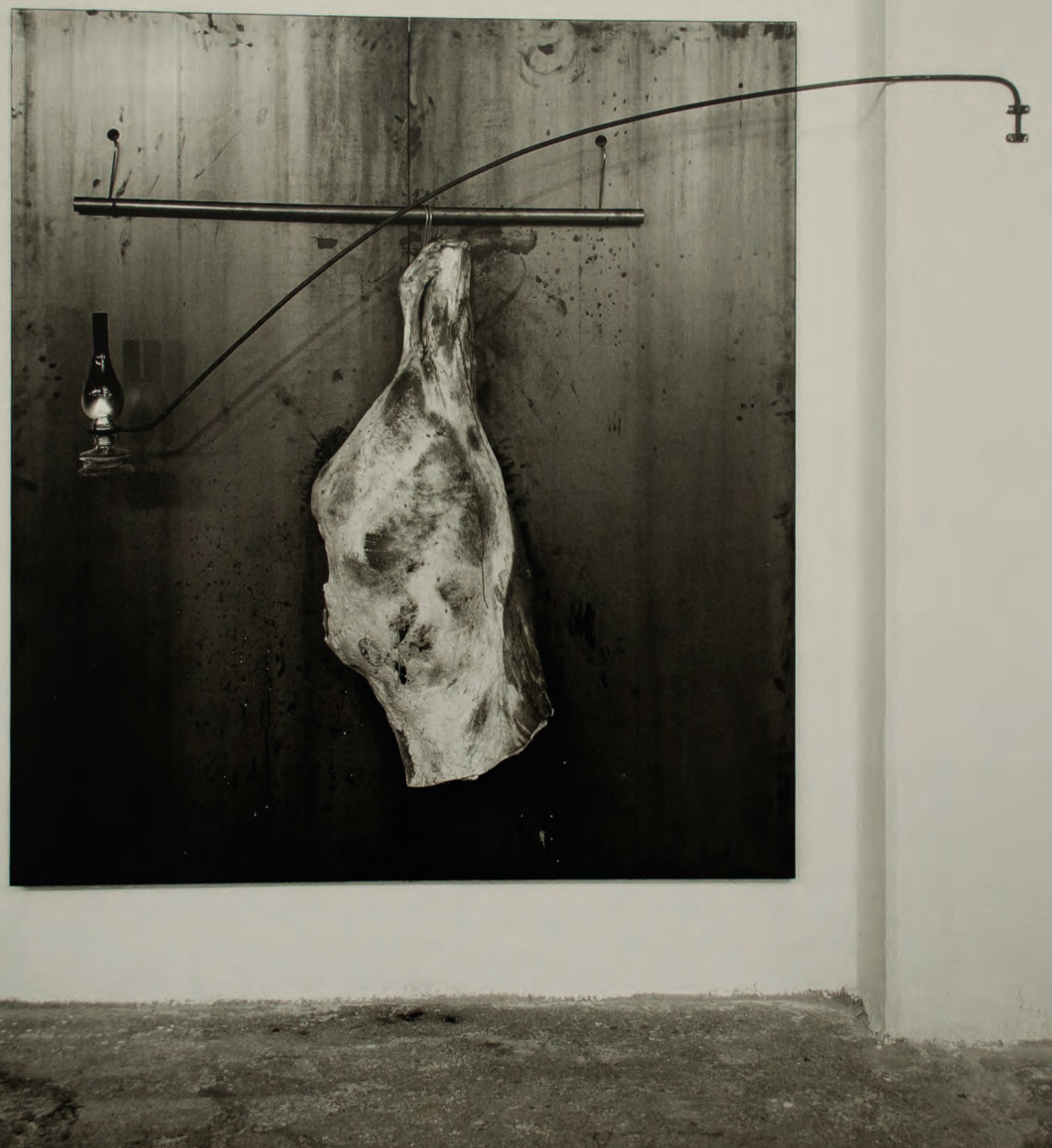


Damisch, em seu livro, analisa como os pintores renascentistas desenvolveram a técnica e a teoria da representação dos corpos e dos espaços tridimensionais em um meio bidimensional, tendo como paradigma o sistema da perspectiva. Contudo, para Damisch, há uma categoria de "coisas" que não são passíveis de representação dentro do espaço matemático da perspectiva, dado que essas "coisas" possuem um corpo sem estrutura, como o fogo, a tempestade, a luz e a nuvens. Logo, representar tais "coisas" exige uma suspensão parcial dos valores que fundamentam a janela renascentista, como a linearidade espacial da perspectiva. Segundo Damisch, o emblemático experimento da tavoletta de Filippo Brunelleschi é um exemplo de como o problema da representação de corpos sem estrutura foi desenvolvido pelos artistas do Renascimento. Nesse experimento, as nuvens são a imagem das nuvens reais refletidas por um jogo de espelhos, ao passo que tudo o que está pintado na tavoletta corresponde ao espaço arquitetônico e urbanístico, ou seja, tudo aquilo que era passível de ser representado pela perspectiva linear.

O conceito de sensibilidade elaborado por Kounellis, como já assinalado, se baseia na apresentação(v) ${ }^{(v)}$ materiais, sensações, objetos e seres cuja natureza é fugidia e não se permite capturar exclusivamente pelo olhar, como o papagaio $^{(\mathrm{v})}$, por exemplo. No entanto, o papagaio não é apresentado solitariamente, mas é exibido em relação a uma chapa de ferro ${ }^{(v)}$, que pontua o conceito de estrutura (ver imagem 51). A chapa delineia o perímetro $^{(v)}$ físico e conceitual ao qual o papagaio se refere, como a arquitetura pintada na tavoletta se estabelece como uma referência espacial e conceitual para a imagem das nuvens. Em outras palavras, a estrutura de metal feita por Kounellis e a arquitetura pintada na tavoletta de Brunelleschi determinam um contexto para a percepção do papagaio e da imagem da nuvem.

Em monografia publicada em 2003, Stephen Bann faz uma leitura da peça Sem título (algodão), de 1967 (ver imagem 2), associando-a a duas pinturas de Edgar Degas cujo tema é um escritório de negociação de algodão em Nova Orleans, e tendo como mediador a teoria de Damisch $^{87}$. Nessa análise, Bann pontua como a representação do algodão, que está no centro das telas de Degas, é delimitada pela representação de homens que trabalham em tarefas pertinentes ao comércio do produto. Ou seja, o algodão, material sem forma e estrutura, é modelado pela atividade humana. O mesmo ocorre com o algodão na obra de Kounellis, tendo em vista que a estrutura metálica da peça é o produto de um esforço técnico humano.
90 Sem título, 1989. Chapas de ferro, pedaços de carne presos por ganchos em tubos de metal e lamparina a óleo suspensa por haste de metal. $200 \times 180 \mathrm{~cm}$. Espai Poblenou, Barcelona, 19891990. Foto: Claudio Abate.
87 Ver Bann (2003, p. 138147). 

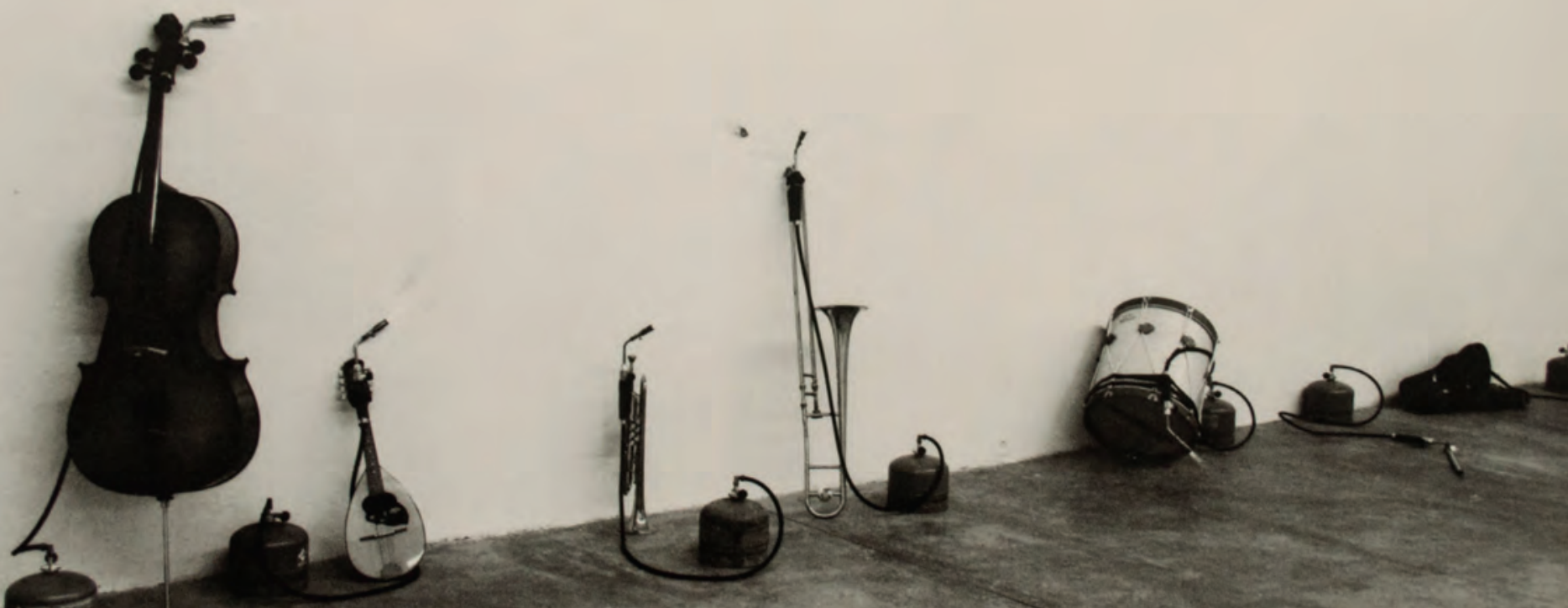
Retomando a leitura tecida, destaco que o contexto oferecido pela arquitetura pintada na tavoletta de Brunelleschi é o mesmo das pinturas de Degas e das chapas de metal da Kounellis, pois, grosso modo, todos se referem à vida humana em sociedades urbanas. Logo, dada a similaridade entre a natureza "sem forma" da nuvem, papagaio e algodão e o contexto aos quais cada um se relaciona, vislumbro uma mesma raiz teórica. Portanto, afirmo que Kounellis não trabalhava para o fim da pintura, mas para a sua realização através de uma linguagem ${ }^{(v)}$ que abarcava o contexto do século XX.

\section{Sino}

O sino foi usado por Kounellis pela primeira vez em 1993, na mostra individual Kounellis: exposição de paisagens de inverno, no Palácio Fabroni, em Pistoia. Nessa exposição o artista desenvolveu um conjunto de obras nas quais os sinos de bronze eram fixados com cordas em grandes colunas de madeira (ver imagem 123). Imóveis, esses sinos apenas evocavam a presença sonora, o que resgata a memória das performances com música $^{(v)}$ realizadas na década de 1970. Para Stephen Bann, os sinos imobilizados, por sua forma e sugestão de movimento, remetem à pintura O balanço, de 1767, de Jean-Honoré Fragonard (1732-1806).

\section{Teatro}

A teatralidade é uma coisa e o teatro é outro. Toda a pintura italiana é teatral até certo ponto. Caravaggio, por exemplo, ou Tiepolo. Esta é uma espécie de teatralidade que busco no meu trabalho. Todavia eu também trabalhei no teatro como pintor. Quero dizer, eu nunca trabalhei como ilustrador, mas trabalhei como cenógrafo, com Carlo Quartucci ou Heiner Müller, em espaços novos e clássicos, como o Teatro Gobetti ou o Teatro Deutsche, ou na Ópera em Amsterdã ou em Berlim, mas com liberdades desconhecidas para um cenógrafo. Trabalhei nesse teatro que buscava suas raízes clássicas e desejava deixar a ambiguidade da comédia burguesa do século XIX. Cenário naturalista ambientado num espaço descritivo que, com tons cinematográficos, sublinha os eventos narrativos: a chamada decoração. Tentamos reconstruir o teatro. Porém, não me fale sobre limites de cruzamento. Eu não sei o que isso significa. Eu nunca ultrapassei os limites ${ }^{88}$.

Ao longo de sua carreira, Kounellis trabalhou em diversas ocasiões como cenógrafo para peças de teatro e óperas, tanto clássicas quanto
91 Sem titulo, 1980.

Instrumentos musicais e maçaricos. Foto: Paolo Mussat Sartor.

92 Sem título, 1972. Kounellis com folhas de ouro moldadas a sua boca, mesa, pianista e cantora lírica repetindo parte da ópera Carmen, de Bizet. Foto: Claudio Abate. I 59 
contemporâneas. O artista colaborou com diferentes diretores, entre os quais cabe destacar: Carlo Quartucci, Heiner Müller, Pierre Audi, Hermann Schneider e Theodoros Terzopoulos.

Uma grande parcela dos experimentos cenográficos de Kounellis foi desdobrada em novas obras de arte após sua apresentação no teatro, dado que toda a fundamentação teórica e técnica da cenografia do artista era baseada na linguagem ${ }^{(\mathrm{v})}$ de seus próprios trabalhos de arte, conforme podemos constatar em "Pensamentos e observações sobre o corpo, sobre o comportamento, sobre o 'natural' e sobre o 'viver' como autenticidade teatral". Ou seja, a atividade cenográfica era também um laboratório para Kounellis.

\section{Trapo}

O trapo é um elemento que aparece na obra de Kounellis geralmente associado a estacas ou estruturas de madeira, em obras da década de 1970 (ver imagens 50, 133 e 135). Para Stephen Bann, o trapo, por suas formas e volumes, associa-se à visualidade do dripping de Jackson Pollock ${ }^{(v)}$. No entanto, creio que o uso do trapo não evoca exclusivamente o dripping pollockiano, mas também se relaciona à fabricação de papel $^{89}$, pois o trapo, assim como a celulose, é uma das matérias-primas desse tipo de indústria. Cabe aqui lembrar que Kounellis trabalhou com as medidas do papel Fabriano $^{(\mathrm{v})}$.

Van Gogh, Vicent (1853-1890)

Pintor holandês. Em 1997, a partir da estrutura ${ }^{(v)}$ peça Sem título, de 1967 (ver imagem 22), Kounellis elaborou para a cidade de Haia uma obra pública tendo como referência Os comedores de batatas, de 1885, de Van Gogh. Essa peça, segundo ele, em "Projeto para escultura em Haia", representava a Holanda que ele imageticamente conheceu através das pinturas do artista. Kounellis afirmava que na franqueza de Van Gogh ao representar os menos afortunados havia "beleza, inovação e justiça" que correspondiam às mudanças na linguagem ${ }^{(v)}$ da pintura $^{(v)}$.

No catálogo da exposição no Stedelijk Van Abbemuseum ${ }^{90}$, em 1981, Kounellis e Rudi Fuchs associaram por meio de imagens a obra Louisiana (ver imagens 139 e 140) à pintura Quarto em Arles, de 1888. Todavia, identifico nas obras de Kounellis feitas de mantas de chumbo
93 Sem título, 1992.

Estrutura de ferro, balanças de ferro, sacos de juta e café. Altura total $1.860 \mathrm{~cm}$. Coleção da Cidade de Barcelona. Foto: Claudio Abate. 


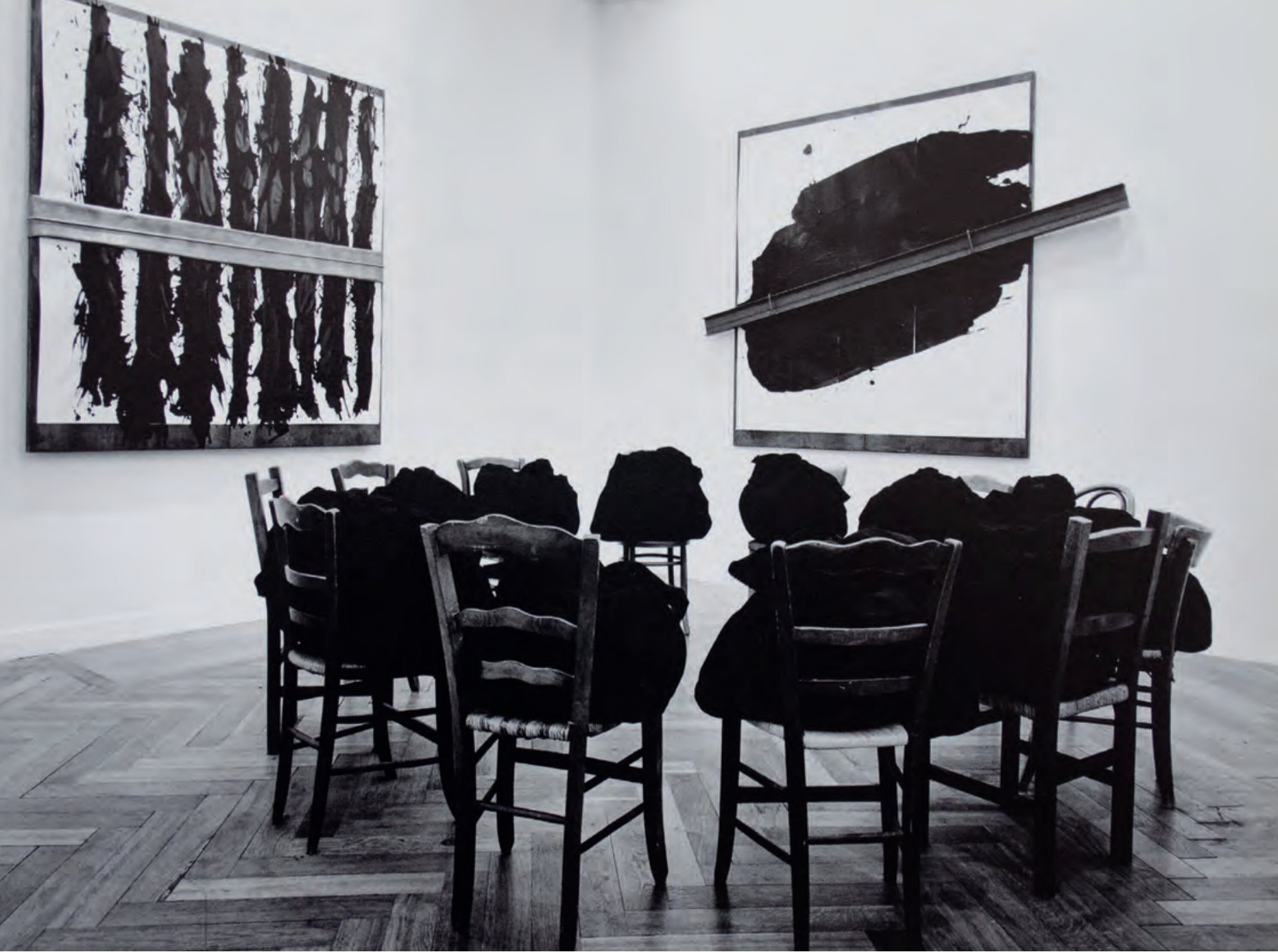


enroladas com peças de vestuário $^{(v)}$ uma visualidade que remete às pinceladas curvilíneas de Van Gogh (ver imagem 53).

\section{Velas de barco}

As velas ou mastros com velas são objetos que evocam a ideia de viagem $^{(v)}$ e que se relacionam às obras produzidas a partir de fragmentos de embarcações $^{(v)}$. Em 1979, Kounellis apresentou na Galeria Salvatore Ala a peça Sem título, na qual duas telas de pintura são penduradas em um mastro com quatro metros de altura (ver imagem 57); e, na parede onde a obra estava montada, marcas de fuligem complementavam o trabalho. Por sua disposição, as manchas de fuligem parecem num primeiro momento emular a sombra do mastro; no entanto, elas desenham outro tipo de espectro.

Tendo em vista as considerações de Kounellis sobre a fumaça ${ }^{(v)}$ e os materiais empregados no trabalho, suponho que a obra extrapola a ideia de viagem ao descrever uma imagem ${ }^{(v)}$ que lembra a ideia da pintura $^{(v)}$, tornando-se também uma metáfora para a conceito de acumulação $^{(v)}$.

\section{Verticalidade}

A verticalidade foi um conceito que Kounellis associou diretamente à ideia de centralidade ${ }^{(v)}$, ao processo de formulação da linguagem ${ }^{(v)}$ e, também, à imagem $^{(\mathrm{v})}$ da catedral $^{(\mathrm{v})}$. Para Mircea Eliade, em $O$ sagrado $e$ o profano, o estabelecimento do eixo vertical era o passo subsequente à determinação do centro pelo homem religioso. A descoberta do centro funda, para Eliade, uma nova espacialidade na qual é possível designar as direções cardeais. Nesse contexto, o eixo vertical corresponde à tentativa do homem religioso de instaurar uma conexão com o plano celestial.

Transpondo as considerações de Eliade para o campo da arte e, em específico, para a poética de Kounellis, suponho que a verticalização do centro está relacionada ao refinamento das formulações ocorridas no interior da linguagem artística, algo similar ao que Vilém Flusser afirma ao comentar a intuição poética:

A intuição poética, ao se chocar contra o inarticulável, arranca dele o nome próprio e volta com esta conquista para o campo do articulado. [...] $\mathrm{O}$ resultado desse choque é o enriquecimento do intelecto por um nome próprio. A língua ganhou, graças a este choque, uma nova palavra ${ }^{91}$.
94 Vista da exposição Zannis Kounellis, Hotel das Artes, Centro Mediterrâneo de Arte do Conselho Geral de Var, Toulon, 2005. Foto: Manolis Baboussis.

95 Sem título, 1976. Forno com chaminé e fuligem. Foto: Claudio Abate. 


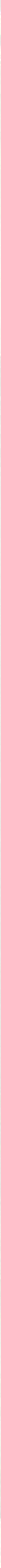


Nesse sentido, a verticalização corresponde ao aprofundamento da linguagem da arte que se manifesta a cada nova concepção materializada pela criação da obra de arte, que, conforme Kounellis, "nasce de uma falta e é visionária pela mesma razão" ${ }^{92}$.

\section{Vestuário}

Em geral, Kounellis utilizou casacos, chapéus e pares de sapatos para delinear uma imagem ${ }^{(v)}$ em escala ${ }^{(v)}$ humana, como fez ao usar a cadeira $^{(\mathrm{v})}$, a mesa ${ }^{(\mathrm{v})}$ e a cama ${ }^{(\mathrm{v})}$. Porém, as peças de vestuário desempenham um papel ambíguo e são sensibilidade ${ }^{(v)}$, porquanto sua presença remete a uma instância da vida e, também, à estrutura ${ }^{(v)}$, dado

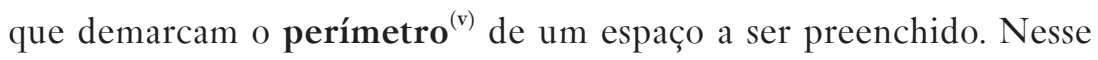
sentido, as peças de vestuário são uma espécie de "casca" que contém o corpo, inserindo-o dentro do contexto da cultura. Entre as obras realizadas com peças de vestuário, destaco Sem título (Tragédia Civil), de 1975, e Sem título, de 2012 (ver imagens 17 e 110), pela sugestão de diálogo com imagens da história da arte.

\section{Viagem}

Uma viagem significa "ir ao outro lado" para mim. Eu me atraio em ir ao outro lado, como qualquer outro artista, por razões culturais e por esse senso de aventura que sempre é instilado na arte. Porém, não é exato afirmar que uma busca é uma jornada para o desconhecido. Sempre se é atraído por algo conhecido, embora seja pequeno. Desejando ver uma pintura de Van Gogh, chega-se em Paris. Encontra-se Paris e com Paris, a cultura francesa...

Cada viagem tem uma natureza iniciática, é uma ideia ativa, amorosa e expansiva do conhecimento. Muitas vezes, as viagens estão implícitas em minhas obras, entretanto seria óbvio associá-las à minha individual no navio. A exposição em Chicago era muito mais parecida com uma jornada, na medida em que se expandia para fora, em direção a outros espaços periféricos, além das salas do museu ${ }^{93}$.

Ao comentar a ideia de viagem, Kounellis se reportou a duas exposições. A primeira delas aconteceu em Chicago, em 1986, e foi intitulada Fannis Kounellis: uma retrospectiva em cinco locais; a outra ocorreu em 1994, no porto do Pireu dentro do navio Ionion, em Atenas. Na exposição de Chicago as obras de Kounellis estavam divididas entre o
96 Vista da exposição fannis
92 (KOUNELLIS; CODOGNATO; D'ARGENZIO, 2002, p. 211).

93 (KOUNELLIS; CODOGNATO; D'ARGENZIO, 2002, p. 102). 


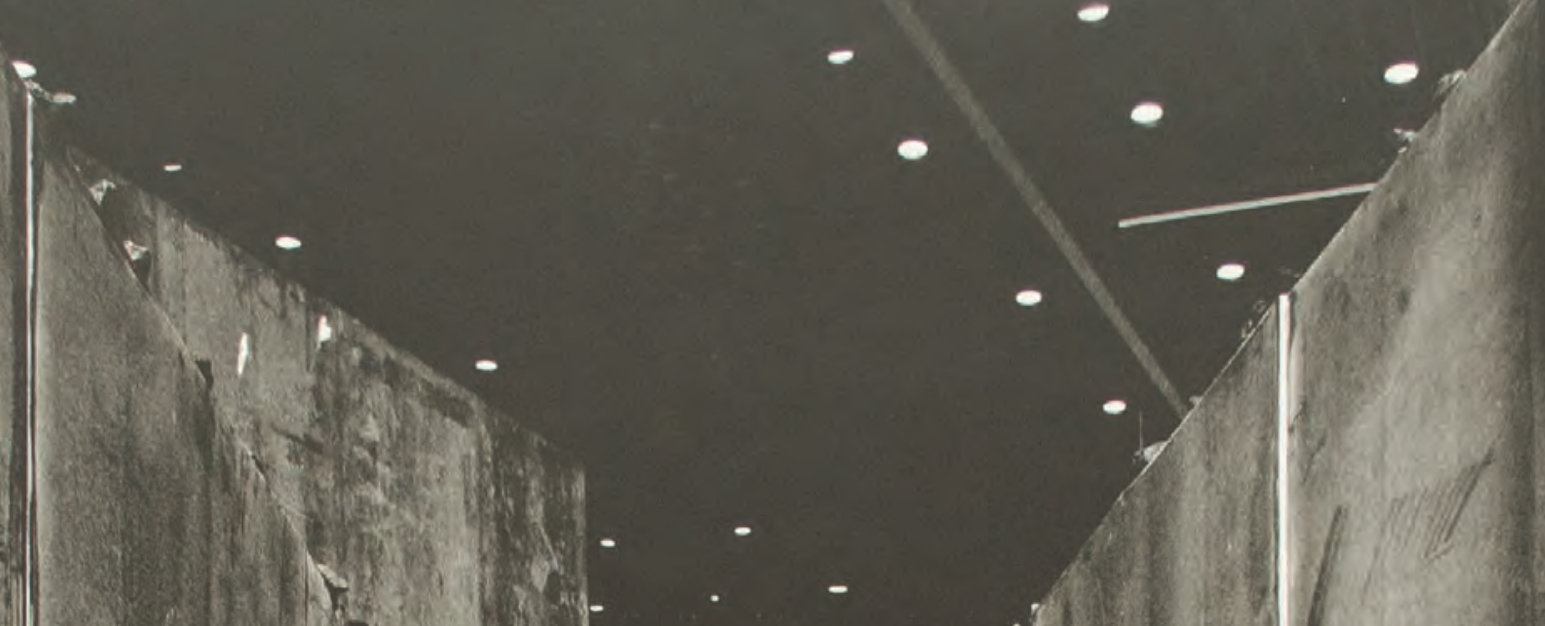


Museu de Arte Contemporânea de Chicago e quatro edifícios históricos da cidade; por isso, o espectador deveria se deslocar entre esses locais para ver as obras. Já na exposição de Atenas, todas as obras estavam concentradas no interior de um navio cargueiro ancorado no porto. Nessa exposição o movimento das ondas era sentido pelo visitante ao entrar na embarcação e ao perceber o deslocamento de uma das obras ali instalada (ver imagem 115).

Contudo, a ideia de viagem não está relacionada apenas aos deslocamentos realizados pelo observador. $\mathrm{O}$ conceito de acumulação ${ }^{(v)}$ articulado por Kounellis como procedimento de trabalho também se reporta às ideias de viagem e migração ${ }^{(v)}$, tendo em vista a remontagem de obras cuja escala ${ }^{(v)}$ e forma foi determinada através da especificidade espacial da primeira montagem no espaço expositivo(v) ${ }^{(v)}$ ou seja, a viagem também está ligada ao deslocamento das obras, exposição após exposição. A ideia de viagem também se materializa metaforicamente em exposições em que Kounellis constrói um labirinto ${ }^{(v)}$ (ver imagens 96, 97, 98, 99, 100 e 131).

Em "Dodecafonia", um dos seus últimos textos, Kounellis retomou aspectos da viagem trabalhados em outros escritos produzidos no decorrer de sua carreira como "Sem título n ${ }^{0}$ 7" julgamento de K.". Neste último, vislumbro, inclusive, uma modalidade de viagem pelo sagrado que me parece descrita pela obra Sem título, de 1975 , na qual as solas dos sapatos do artista foram folheadas em ouro(v) (ver imagem 199).
97 Vista da exposição fannis Kounellis. Neue National Galerie, Berlim, 2007. Foto: Manolis Baboussis.

98 Vista da exposição fannis Kounellis - Ato Único, Fundação Arnaldo Pomodoro, Milão, 2006. Foto: Manolis Baboussis. [Página dupla] 



\section{Ei! O que está acontecendo? Ei! I 967}

Publicado originalmente em Kounellis, Roma: Galeria I'Attico, 1967.

Kounellis: Ei! O que está acontecendo? Ei! (Dirigindo-se ao papagaio)

K.: O que ele estava fazendo? Dói quando ele faz isso? Isso está doendo?

O quê?

Criança 1: Sim, isso dói.

Criança 2: Isto se parece com um jardim. (Estamos em frente à estrutura com a terra e as plantas)

Criança 3: Não, estas são folhas.

Criança 4: Que é isso debaixo do seu nariz? (Dirigindo-se ao papagaio)

K.: Prestem muita atenção, vocês podem fazer isso? Que cor é essa?

C.1: Verde.

K.: E você?

C.2: Verde... cinza e preto.

K.: O quê?

C.2: Cinza e preto!

K.: E você?

C.3: Cacto... amarelo.

C.1: Você não entende, ninguém entende nada.

K.: Que flor é essa?

C.2: Um cacto.

C.3: Eu estou com sono.

K.: Vocês gostam dos cactos?

C.1: Não!

K.: Por que não?

K.: Olhe, tenha cuidado, ele pode cair.

C.1: Por quê?

K.: Porque eles são bem pequeninos.

C.1: Bem, eu posso falar? Posso dizer algo?

K.: Vocês viram o peixe? Venham, venham comigo. Como é o peixe?

C.1: Pequeno.

C.2: Não é grande, é preto. Tem uma cauda preta.

C.3: As folhas são verdes, e o ferrão do peixe?

K.: Ferrão?

C.3: É de todas as cores e transparente. de pequenas montanhas. 


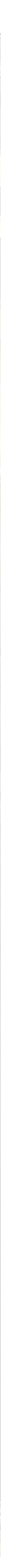


K.: E você que não está dizendo nada. Você está olhando para o peixe? Você gosta dele?

C.1: Não desse jeito!

C.2: Peixe!

K.: E o que é isso? (Na frente da estrutura com cactos)

C.2: Uma flor.

K.: Não, este aqui produz figos. Figos, já ouviu falar? E quem é aquele?

C.2: Figos!

K.: Luca, Luca... é macho ou fêmea?

C.1: Ele é um menino que parece uma menina.

K.: Agora vamos ver o que ele tem a dizer. 


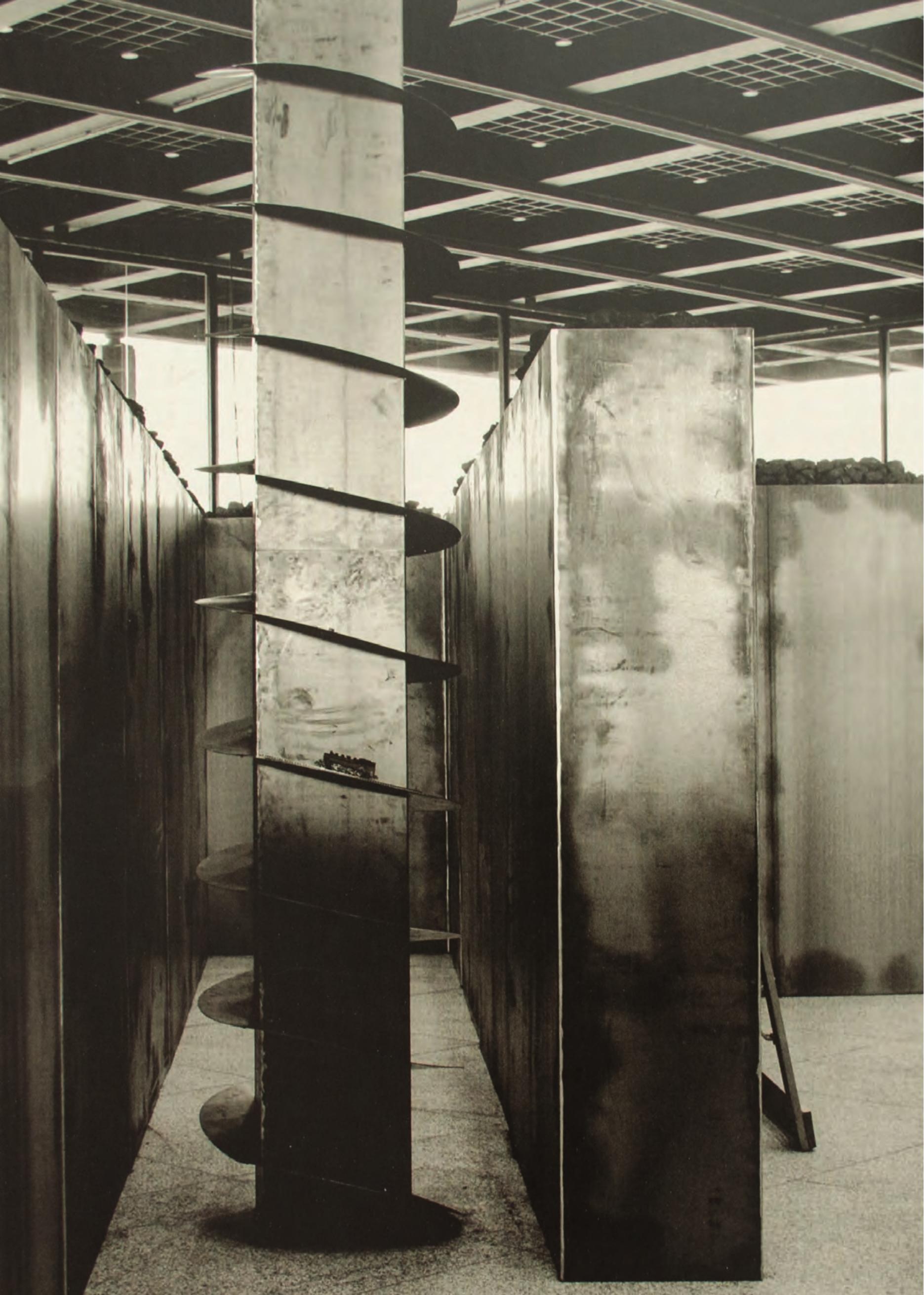




\section{Pensamentos e observações sobre o corpo, sobre o comportamento, sobre o "natural" e sobre o "viver" como autenticidade teatral i 968}

Publicado originalmente na revista Mercatrè, Milão, n 43-45, julho-setembro de 1968, p. 230-237.

Um pode e um deve partir do próprio corpo, tanto o ator como o espectador (no palco e na vida, respectivamente). E isso pode e deve ser realizado como um comportamento alternativo, para o ator e o observador (recitando e vivendo). Dessa forma, o corpo e o comportamento não são mais desunidos, não seguem seus caminhos separados. O que é antigo no teatro, o que finalmente está morto, é precisamente a contradição existente e persistente no palco (e na vida) entre o que é fisicamente assumido e a forma como se comporta diante dessa condição física. Desde o início, essa "corporeidade" deve ser entendida não como uma tendência a conquistar "tecnicamente" uma forma expressiva, mas sim como uma tendência a assimilar moralmente uma "autenticidade"; é aqui que a demanda extraordinariamente "ativa" nasce de uma concordância entre o que é feito no palco e as reações que são produzidas lá, a partir do momento em que apenas uma autenticidade profunda é capaz, pelo menos hoje, de corrigir se não transformar a maneira antiga de fazer o teatro, a de estar dentro do "produto" e não querer estar livre disso. Por autenticidade profunda, queremos dizer aqui um "gesto" continuamente rebelde contra ser encerrado em "produto", rebelde sob a forma de "material" ou sob a forma de "expressividade." Um gesto rebelde "material" e "expressivo" que, com um incômodo permanente, coloca em contato o ator e o personagem que ele retrata, e também com um incômodo permanente o espectador e a ação em que ele é chamado a participar.

$\mathrm{O}$ ator, que tem que se conformar com ele no momento em que enfrenta o personagem, deve encontrar sua própria autenticidade, mais do que no sentido da técnica teatral, em um sentido moral libertador, enquanto o entorno "se materializa", para ele depositar nos objetos,

101 Sem título, 1997 Sete vigas de metal com helicoidais de ferro fixadas; em uma das vigas há uma miniatura de trem elétrico. $1400 \times 40 \times 40 \mathrm{~cm}(\mathrm{cada}$ viga). Museum Ludwig, Halle Kalk, Colônia, 1997. Foto: Aurelio Amendola. nas cenas e nas luzes da pátina do convencionalismo e da ficção que é meramente uma projeção de idealismo credível, e então faz essa "materialização" expressiva através de uma busca de espaço "vivo" dentro do cenário, baseado não em uma apropriação de noções teatrais, mas em uma interiorização de gestos "rebeldes" antes dele e tudo o que ele deve que enfrentar. Essa "autenticidade" não pode, em nenhuma 


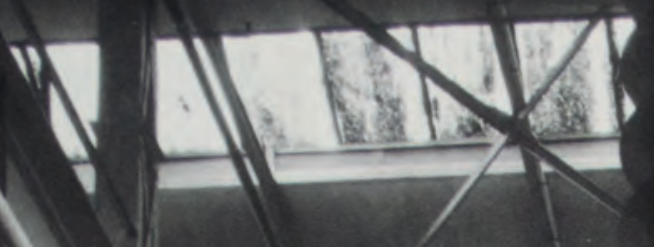

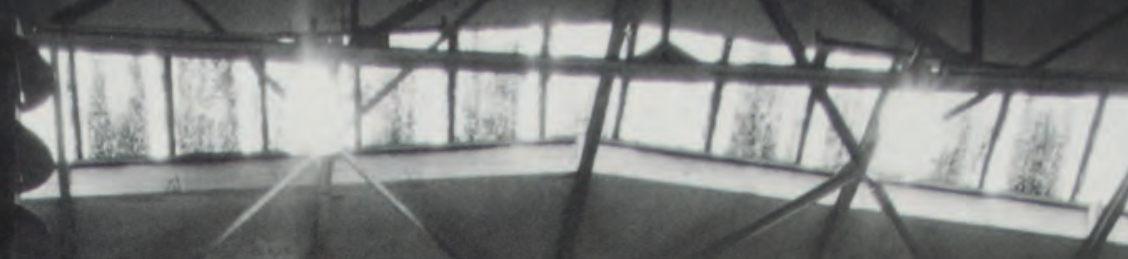
5 Mns (N) $M V=$ 2) NDI +5 $54=\sqrt{2}$

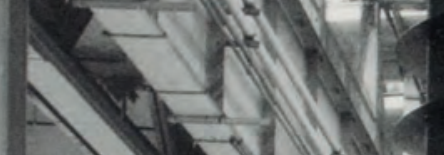

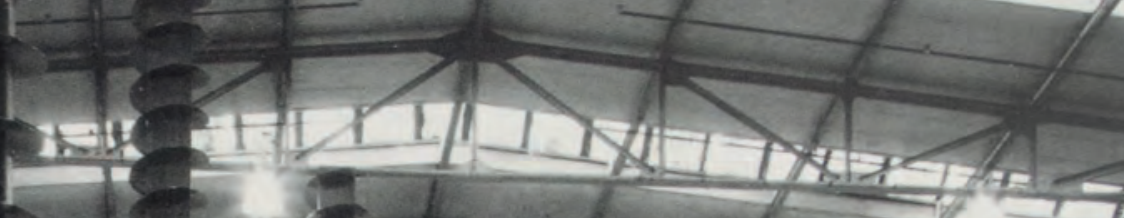

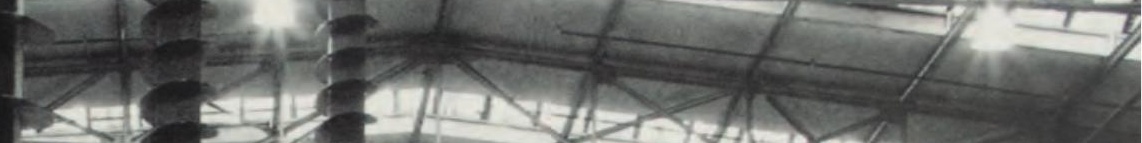

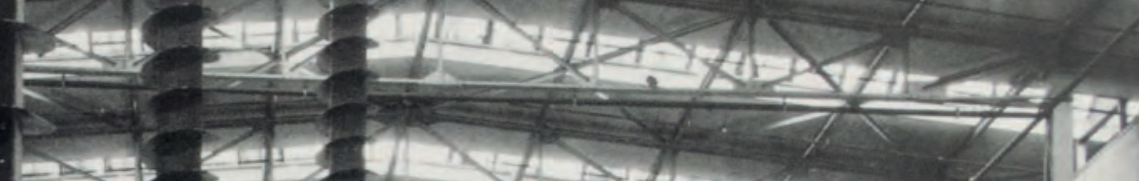

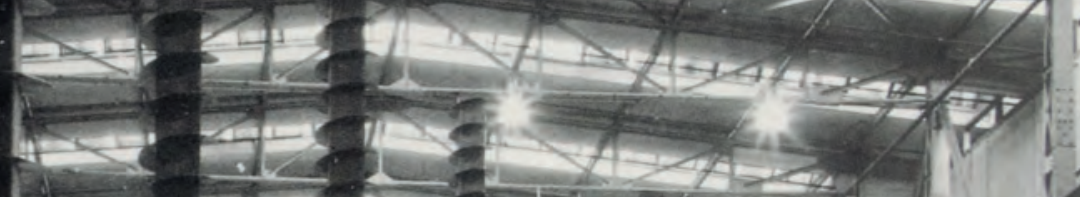
$\therefore$ | $-\lim _{x \rightarrow \infty}$

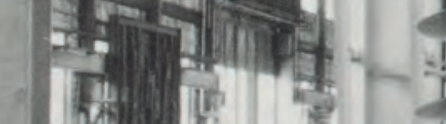

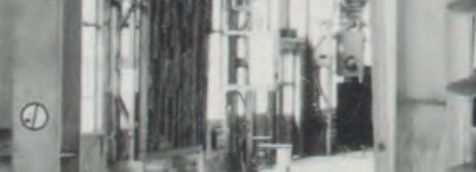

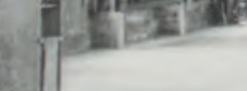

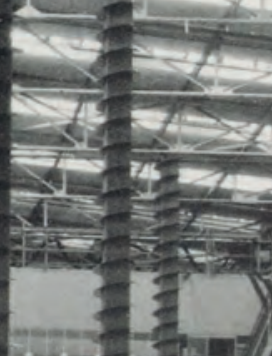


circunstância, ser entendida como uma busca de naturalidade realista, mas para o "verdadeiro" e o "vivo" que são elementos que impulsionam uma ação de palco é preciso se despojar de convencionalidade e técnica ao mesmo tempo: por essa razão, é justificado o uso de elementos como plantas, pássaros, carvão, algodão, pedras, no caso concreto de The Witnesses, porque, em virtude de sua formação e verdade, são portadores de uma "nostalgia" e de um "incômodo", tanto para os atores quanto para os espectadores, que são positivamente condicionados a eles e os admitem como "sinal" de alteridade e como "indicadores" de não convencionalidade. Essa interiorização da "autenticidade" não pode, por outro lado, limitar-se a constituir um espaço "vivo" em si, isto é, por razões puramente estéticas, como se fosse o suficiente para ter um pouco de "verdade" e um pouco de "vida" no palco para determinar uma alteração teatral; se esse fosse o caso, e como vimos, isso se tornaria apenas uma correção de uma natureza teatral. Essa interiorização deve tender a uma condição de transformação qualitativa da ação de palco, no sentido de que o próprio ator nesse espaço "vivo" - criado pelos elementos "verdadeiros" e "vivos" e pela atitude não convencional que ele adotou - está em condições de assimilar um tipo de comportamento que vai além do "incômodo" para alcançar a "alteridade".

Em qualquer caso, trata-se do limiar de "alteridade", e não de "alteridade" total: em outras palavras, de uma espécie de rejeição do "produto" dentro do "produto" que, quanto mais exaltado e expandido pelo ator (e, portanto, pelo espectador nesse papel como "cúmplice" visual e mental da ação no palco), o mais expansivo e o mais invasor é o comportamento. Por enquanto, o que deriva disso é uma infelicidade por parte do ator (e do espectador), tomado de surpresa com a rivalidade representada pelos pássaros (seu gorjear incessante e desordenado), o carvão, as pedras, o algodão (que são respectivamente o solo, o "inútil" e o criador de falsa "beleza") e que se submeteu ainda a um movimento dos "carrinhos de mão" que são, ao mesmo tempo, estrutura de rolamento e a manifestação alteradora (incapaz de viver em um espaço "único" para se comportar de acordo com as regras de credibilidade).

Essa infelicidade é dita a consciência da crise: é a objetivação da percepção de que não é mais possível fazer o teatro humano, de acordo com a perspectiva projetada pela rotina e arquitetura "burguesa"; é também a explicação de uma "rebelião" que, com base no "incômodo" do

102 Vista da exposição Kounellis: a frente, o pensamento, a tempestade. Halle Kalk, Museu Ludwig, Colônia, 1997. Foto: Aurelio Amendola. próprio corpo, se estende à "negação" do comportamento convencional e a uma profunda desolação que não é nem imóvel nem mítica, mas saudável na medida em que é movimento e materialização.

No momento em que a consciência da crise se dilata e atinge a totalidade da ação no palco, abrangendo o espectador como "cúmplice" e 
como "testemunha", então o ator começa a estar em posição de "sair" do produto e se tornar um "portador" de elementos "verdadeiros" e "vivos", coincidindo com seu reconhecimento da "infelicidade" produtiva e com sua desarticulação da rotina "técnica".

Assim, não é outra coisa senão a obstinação salutar de Rozewicz (no caso de The Witnesses), de sua crença desesperada no "verbo", no mesmo momento da dolorosa percepção de que qualquer ação teatral dedicada hoje ao "verbo" é de necessidade dividida; e sua teimosia salutar que dela decorre de uma matriz poética "mais feliz" em que o "verdadeiro" e o "vivo" têm seu lugar perfeitamente legítimo, sem nostalgia poética, mas com profunda sensibilidade realista. O que é "feliz" é imediatamente fechado por trás do bloqueio e da chave, precisamente na medida em que tal disposição leva a um comportamento nostálgico e não efetivo; Rozewicz está ciente disso e luta com todos os meios à sua disposição, da ironia ao sarcasmo, da "singularidade" à "ambiguidade", em uma "ação" dramática ao contrário, como em uma contagem regressiva, até a explosão final ser atingida.

Aqui a explosão final é o silêncio: o vazio do palco. Um silêncio que não é sensível, mas difícil. Isso é não conciliador, mas amargo. O vazio não tem caráter simbólico ou imaginário é simplesmente o vazio da crise de fazer teatro, também como "incômodo", como uma "rebelião", se esse "incômodo" e essa "rebelião" não incluem o comportamento de todos, se eles não alcançam a "autenticidade" para sempre. E como isso não ocorre, pois o "produto", embora intacto, permanece, porque os autores do "produto" não modificam suas vidas e atingem apenas a infelicidade, toda a ação cênica é "dessacralizada" pelo desespero. Os próprios "trabalhadores", que realizaram o movimento dos "carrinhos de mão" com indiferença, sem alcançar e sem querer contribuir para o desenvolvimento da ação e para a introdução do vazio e, na contramão, sem solicitar essa ação e esse vazio (apesar de serem infelizes e conscientes de uma crise) de qualquer salvação ou reabilitação, os "trabalhadores" mostraram pelo seu "repouso" teatral, num silêncio extraordinariamente cheio de significados, tanto "verdade" como "vida", que nem mesmo esse teatro, nem mesmo esse incômodo faz parte de suas preocupações ou de seus interesses. Felizmente, por enquanto, eles não querem sequer propor qualquer outra coisa, nada "moral" ou "político" ou "comprometido" em

103 Vista da exposição Jannis Kounellis. Neue National Galerie, Berlim, 2007. Foto: Manolis Baboussis. geral, uma vez que, por sua vez, a sua indiferença também é meramente um encerramento e não uma abertura à "infelicidade"; em qualquer caso, seu comportamento, sua alimentação, sua "reposição" altamente natural pode ser vista como uma reivindicação "genuína", na medida em que são eles próprios, no teatro, no palco, que não pedem nenhuma explicação, nenhuma determinação, exceto a possibilidade de estarem juntos em 


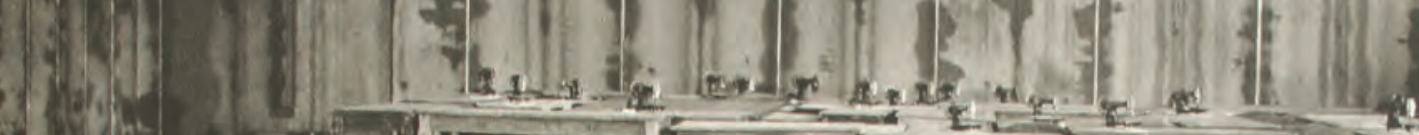

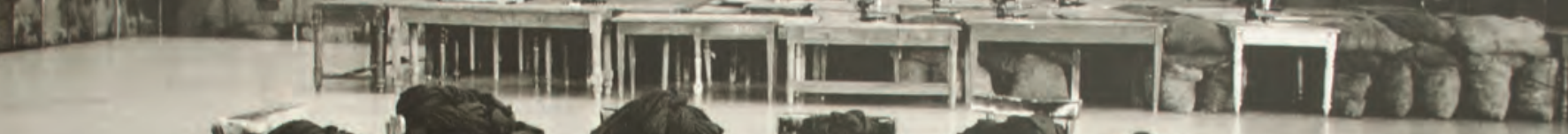
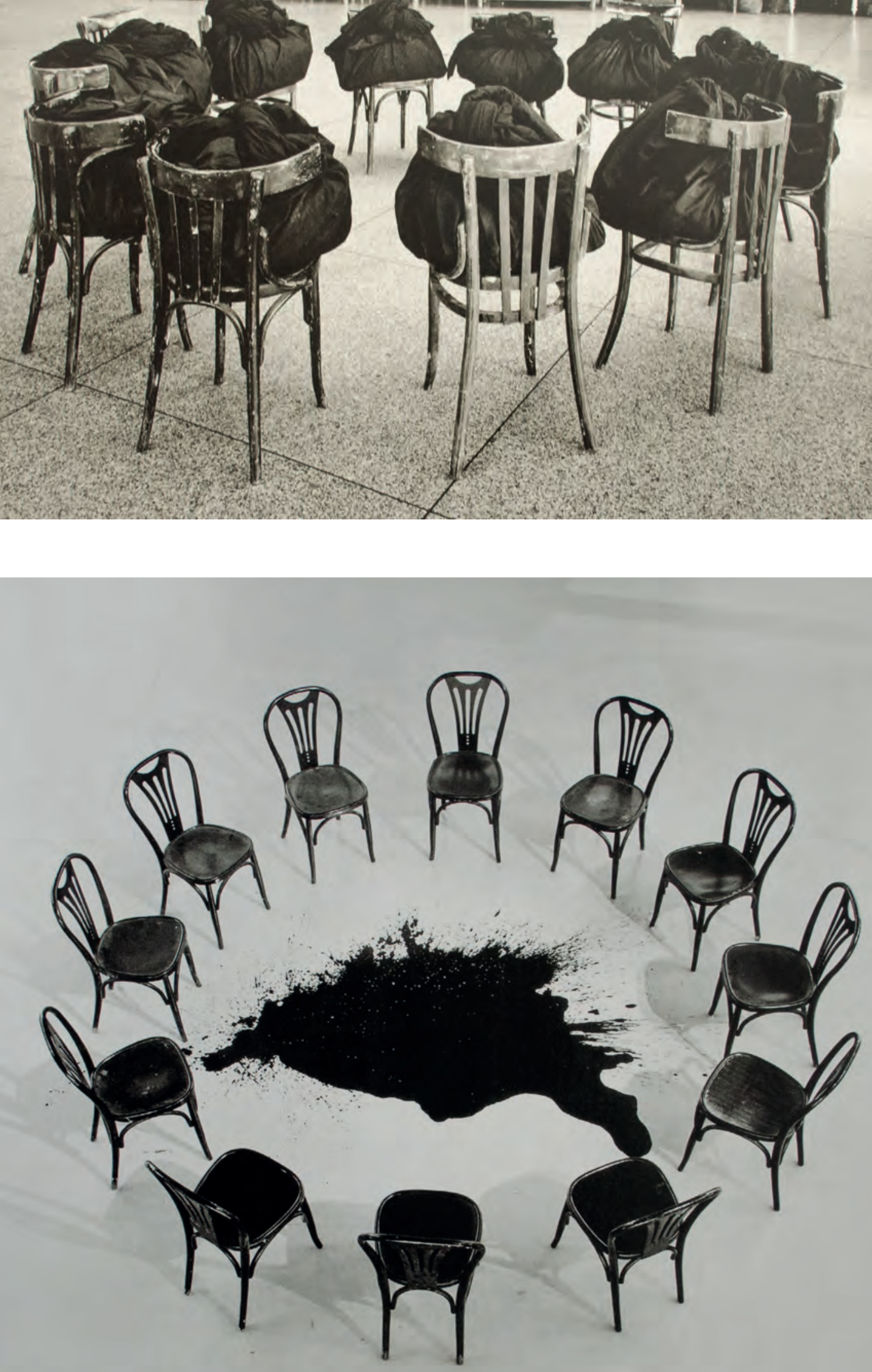
silêncio, trabalhando, por "natureza". No limite dessa "naturalidade" reside o fato de que não contribui com nenhuma mudança para o espaço "vivo" de The Witnesses. Consequentemente, o vazio final deve nos deixar ainda mais ansiosos, precisamente por causa da extrema fragilidade da sutileza da operação de "rebelião", levada a cabo contra uma intriga "natural" de naturalidade "verdadeira", dentro do "produto" e sem liberá-la da "ambiguidade", exceto por essa ambiguidade inerente ao procedimento adotado, ao artifício seguido. 


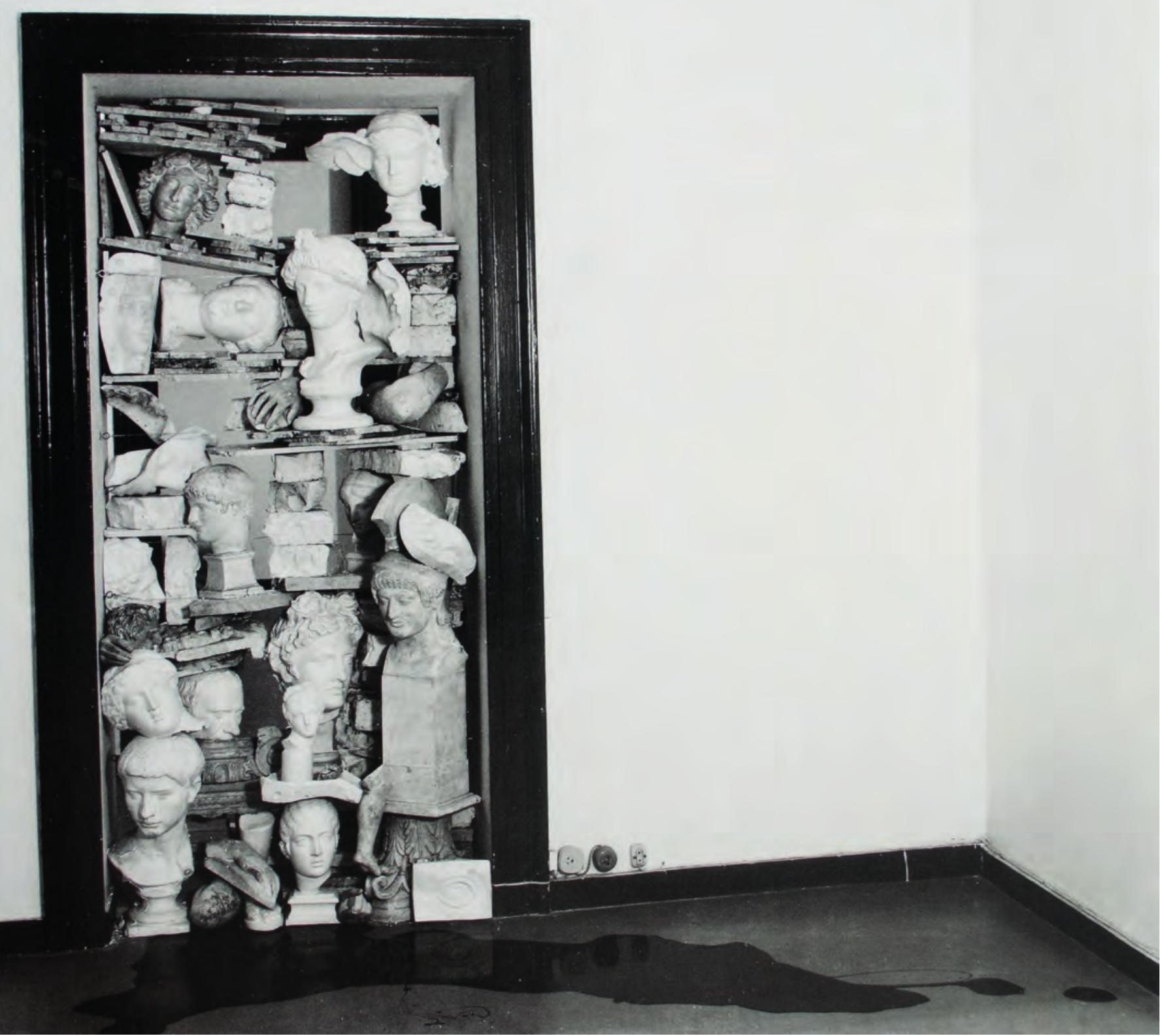




\section{Para Pascali 1969}

Publicado originalmente na revista Qui arte contemporanea, Roma, $n^{\circ}$ 5, março de 1969, p. 22-23.

A) Pino gostava:

De Pollock

Do mar (pesca subaquática)

De jogos (brinquedos)

De Rauschenberg

De Jasper Johns

De armas

De ferramentas de trabalho

De Oldenburg

De Scarpitta

Da América: em sua imaginação

na infância

seu potencial vital ...

em certos filmes ...

E das garotas ...

B) Pino gostava da pintura americana porque odiava todo esse culturalismo mastigado e putrificado da pintura europeia (com exceção de Burri). Pollock e Burri foram o começo de tudo... A pintura americana, porque era um outro mundo, "era" outro mundo... Pino pintou aquele grande torso, com o resplendor do brilho de propaganda de calçados na Broadway... uma coisa que ninguém menciona sobre Pino é a sua capacidade de evocar...

C) Nunca vi aquele vermelho, na Itália, nos lábios daquela grande boca... como uma imagem que pertence - e vem - ao trauma do desembarque nas Américas, a impressão visual das armas, equipamentos, tendas, caminhões e todo o resto que permanece na memória de um homem... o sonho de um mundo criado na infância, não como uma experiência lírica (sem necessidade de pensar sobre a infância, ela vem por sua

106 Sem título, 1974 Sala pintada de amarelo,

Kounellis montado a cavalo usando a máscara de Apolo e lamparina. Galeria

Sonnabend, Nova York, 1975. Foto: Claudio Abate. própria vontade, naturalmente) etc, mas mais como... construir a própria identidade e estabelecer o próprio mundo. (Fiquei profundamente impressionado com a forma como Lichtenstein reproduziu imagens de quadrinhos, referindo-se àqueles dos anos quarenta, ou seja, a uma dimensão de vida onde essa linguagem é a chave). 


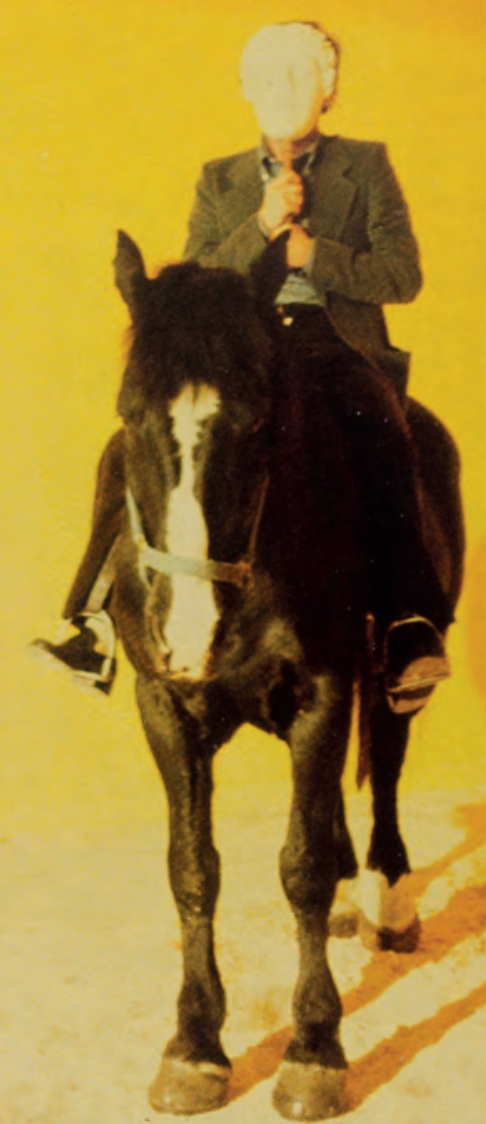


Sim, Pino mudou: seu evidente desenvolvimento nos últimos anos solidificou cada vez mais a libertação - na condição real - dessa dimensão de seu ponto de partida. Ele estava mais perto dessa realidade porque ele se distanciou dela como se fosse uma petrificação histórica, para conquistá-la como sua própria realidade individual, biológica, natural... uma realização da fantasia... de modo que a ponte de lianas pertencente à criação de uma realidade encontrada na escuridão do cinema, nos filmes de Tarzan: através da evocação, "ocupou" um espaço funcional e abstrato para a realidade de sua própria individualidade não mecânica, não abstrata... tudo isso é o oposto do conjunto decorativo, mas pode usar os mesmos procedimentos: um cubo pode ser feito de papelão coberto com terra...

107 Vista da exposição Fannis Kounellis. CAPC Museu de Arte Contemporânea, Bordeaux, 1985. Foto: Claudio Abate. 



\section{Prêmio Pascali 1979}

Publicado originalmente em V Premio Nazionale "Pino Pascali": Jannis Kounellis, Bari: Pinacoteca Provinciale, 1979, p. 6.

Nunca aconteceu que alguém me concedesse um prêmio em meus muitos anos de trabalho. E mesmo que me premiassem, eu nunca teria aceitado. Aceitei o Prêmio Pascali, apesar de contradições tão óbvias e evidentes, porque comemora um amigo artista com quem compartilhei muitos sonhos sobre trabalho e o futuro deste país. Neste ponto político particularmente difícil (e, portanto, também cultural e artístico), quando críticos oficiais, endossando uma restauração do Novecento, em breve, indubitavelmente, darão aos nossos trabalhos essas cores, gostaria de chamar a sua atenção para a sensibilidade poética, para os problemas internacionais, críticos, imaginativos e de natureza visionária. Em outras palavras, os problemas da minha geração. 


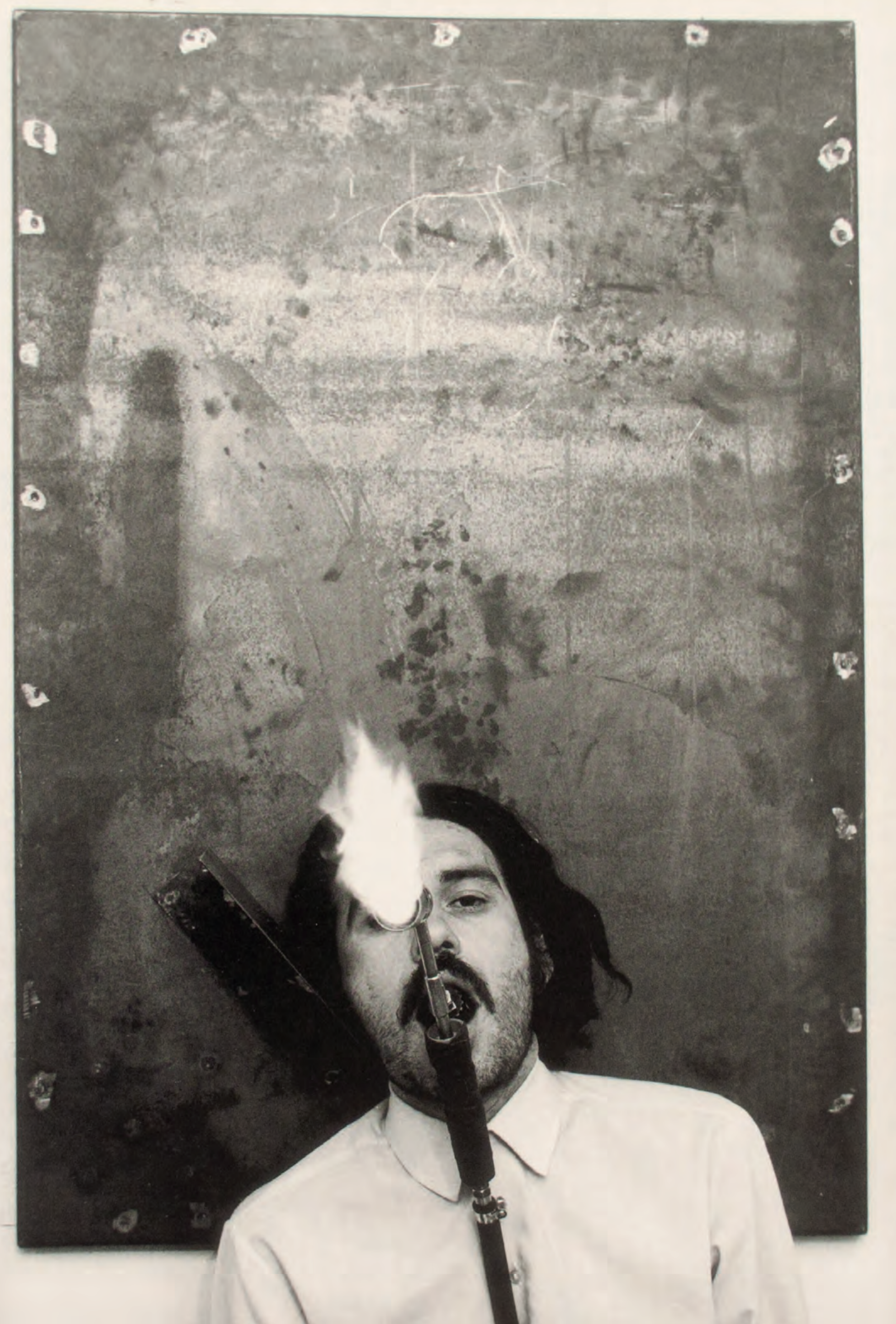




\section{Kounellis I980}

Publicado originalmente no foto-livro Kounellis, Nápoles: Galleria Lucio Amelio, p. 2.

Kounellis nasceu em Alexandria em 1896. Atualmente, ele vive gravemente doente perto de Dublin. 

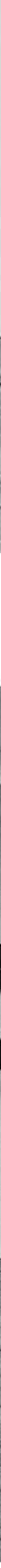


\section{Apesar das contradições de estilo I 98 I}

Publicado originalmente em Jannis Kounellis, Eindhoven: Stedelijk van Abbemuseum, 1981, p. 3

Apesar das contradições de estilo, e não querendo causar nenhuma confusão crítica, eu gostaria de dedicar esta exposição ao lendário pintor Andrei Rublev e seu belo país. 

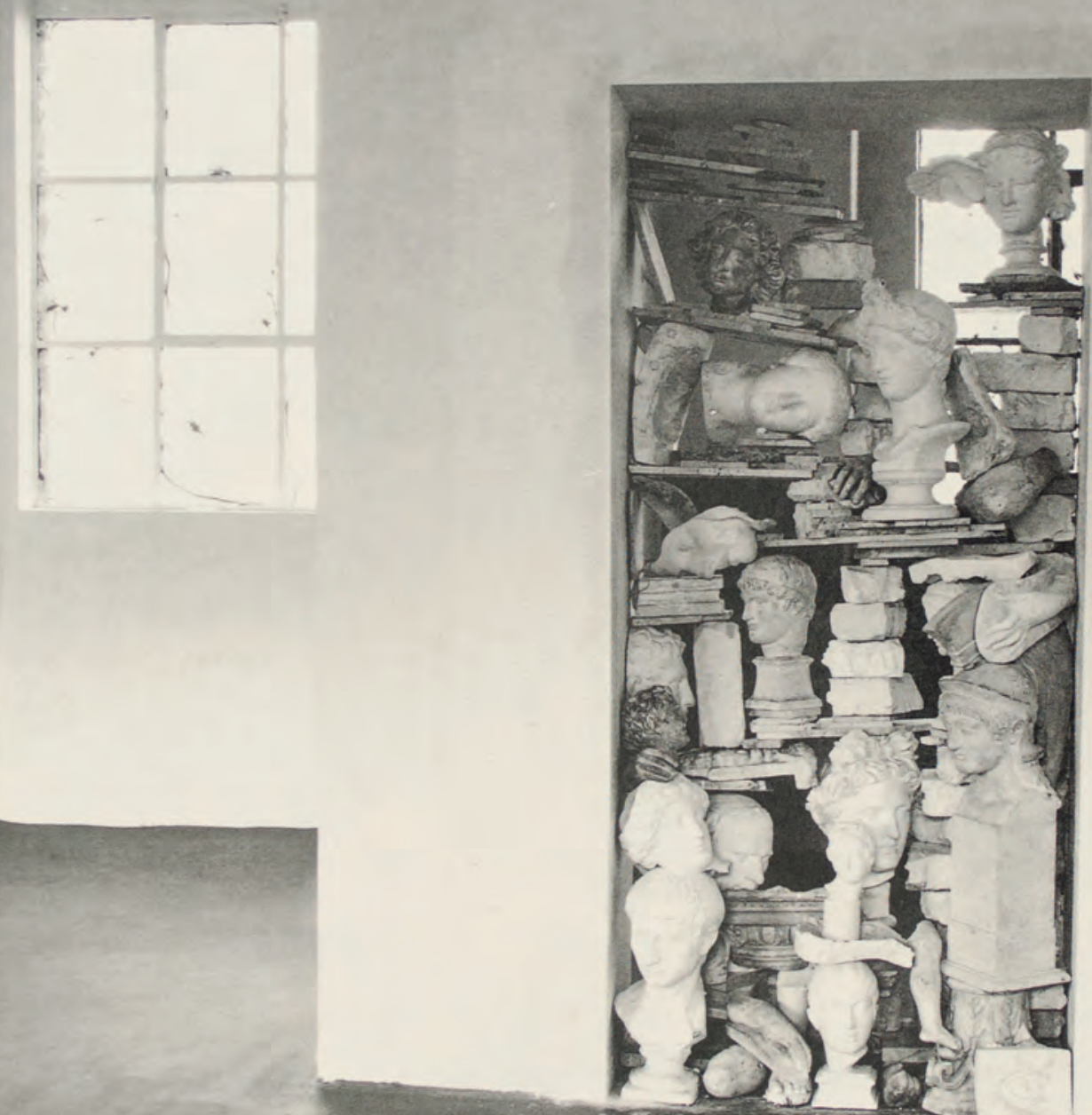


\section{Homem da Antiguidade, um artista moderno I 982}

Publicado originalmente na revista Vardar, $n^{\circ} 2$, Madrid, fevereiro de 1982, p. 1-2

Eu estou contra o mundo de Andy Warhol e seus descendentes de hoje.

Eu desejo restaurar a atmosfera dos tempos cubistas.

Eu estou contra o estado de paralisia resultante da era do pós-guerra.

Em vez disso, eu busco nos fragmentos (de sentimentos e forma) dispersões perdidas da história.

Eu busco desesperadamente a unidade, embora difícil de alcançar, embora utópica, embora impossível e, portanto, dramática.

Eu estou contra a estética da catástrofe; sou a favor da felicidade; procuro o mundo que nossos antepassados vigorosos e orgulhosos do Novecento nos deixaram, exemplos de forma e conteúdo revolucionários.

Eu sou um admirador de Pollock, por sua busca dramática e apaixonada por identidade.

Eu sou um viajante experiente, conheço as estradas tortuosas da minha terra europeia, os caminhos das montanhas e as grandes cidades com suas histórias de bar e discussões apaixonadas.

Eu amo as pirâmides egípcias, eu amo Caravaggio, eu amo Van Gogh, eu amo o Partenon, eu amo Rembrandt, eu amo Kandinsky, eu amo Klimt, eu amo Goya, eu amo o ímpeto da Vitória Alada de Samotrácia, eu amo as igrejas medievais, eu amo o personagem de Ofélia como Shakespeare a descreve, eu honro os mortos, enquanto penso em mim como artista moderno. 

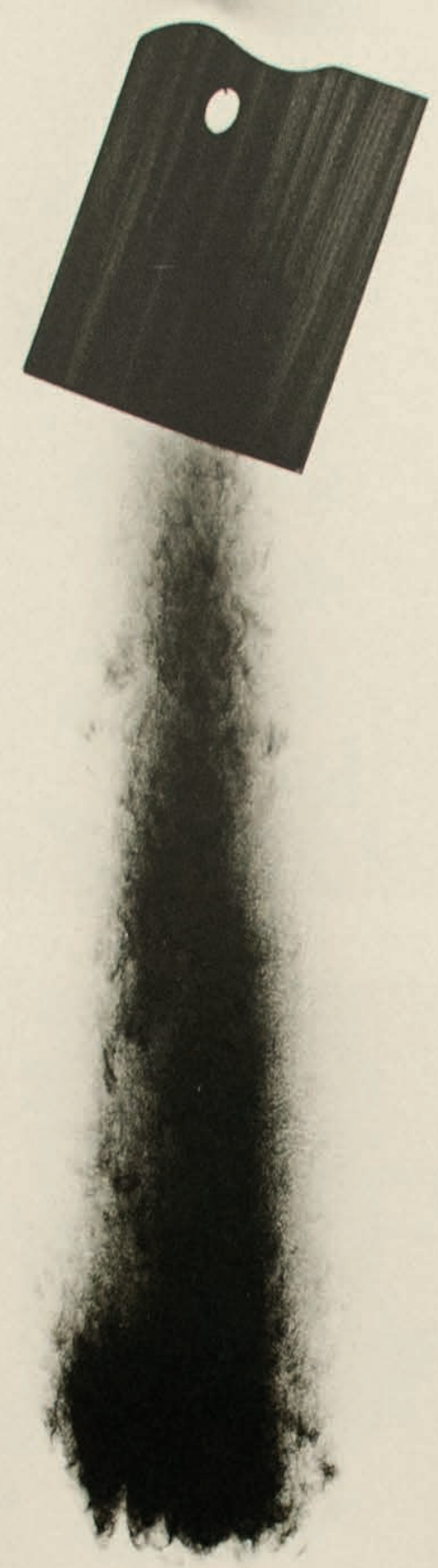


\section{Eu estava procurando a cabeça de Safo I 982}

Publicado originalmente em Zeitgeist, Berlin: Galerie Martin Gropius-Bau, 1982.

Eu estava procurando a cabeça de Safo que estava no canto da borda e, em vez disso, encontrei, sob uma árvore caída, a mão que segurava os cabelos da vitória nas pontas de seus seios. Meu Deus! O pé de Apolo, que estava no pedestal na entrada, foi arruinado. Na máquina de escrever, os comandos escritos, o queixo e a boca dourada de Dafne. Que loucura, que transtorno. O tambor abandonado na cadeira, o uniforme na cama; a lâmpada mal ilumina. A cabeça de Agamenon no canto; as paredes parcialmente derrubadas; a soldado ferido adormecido.

Lembram a imagem dos desenhos de Moore 1940-41

Lembram as gravuras de paisagens romanas de Piranesi

Lembram Delacroix

Eu me lembro da harmonia da Catedral de Troia

Eu me lembro do Partenon

Eu me lembro da invenção de perspectiva por Masaccio

Eu me lembro de David

Eu me lembro de Malevich

Que desordem. Um fragmento do olho da estátua de Atena na escada que conduz ao jardim, a bandeira, a batalha, o rifle, a ponte de ferro, o rio, os comandos, os tiros, a dor, a perda, as caminhadas, a derrota, a cabeça em um relevo acima da janela perto do canto, a mão do cavaleiro de bronze na entrada, a epígrafe ilegível, o ferro, a máquina de costura, a bengala, o trompete, o guarda-chuva, as meias, os sapatos, os óculos coloridos, o vidro quebrado...

A cabeça de Vênus à direita; À esquerda, a cerca de um metro e meio de distância, o ferro; Perto da direita, a bandeira, a bengala à esquerda, 50 centímetros à esquerda, os sapatos e as meias; À direita da cabeça

114 Vista da exposição fannis Kounellis. Navio Cargueiro Ionion, Pireu, 1994. Foto: Aurelio Amendola e Manolis Baboussis.

115 Vista da exposição Jannis Kounellis. Navio Cargueiro Ionion, Pireu, 1994. Foto: Aurelio Amendola e Manolis Baboussis. de Apolo, a cerca de 30 centímetros, o olho da estátua que encontrei na escada que levava ao jardim; Máquina de costura, trompete e guarda-chuva à direita dos sapatos e meias; À esquerda da cabeça de Apolo, as pedras, os mármores, os pedaços de madeira, o vidro quebrado e a poeira;

Eu me lembro de Schwitters

Eu me lembro de Picasso

Eu me lembro de Cézanne

Eu me lembro de Pollock. 

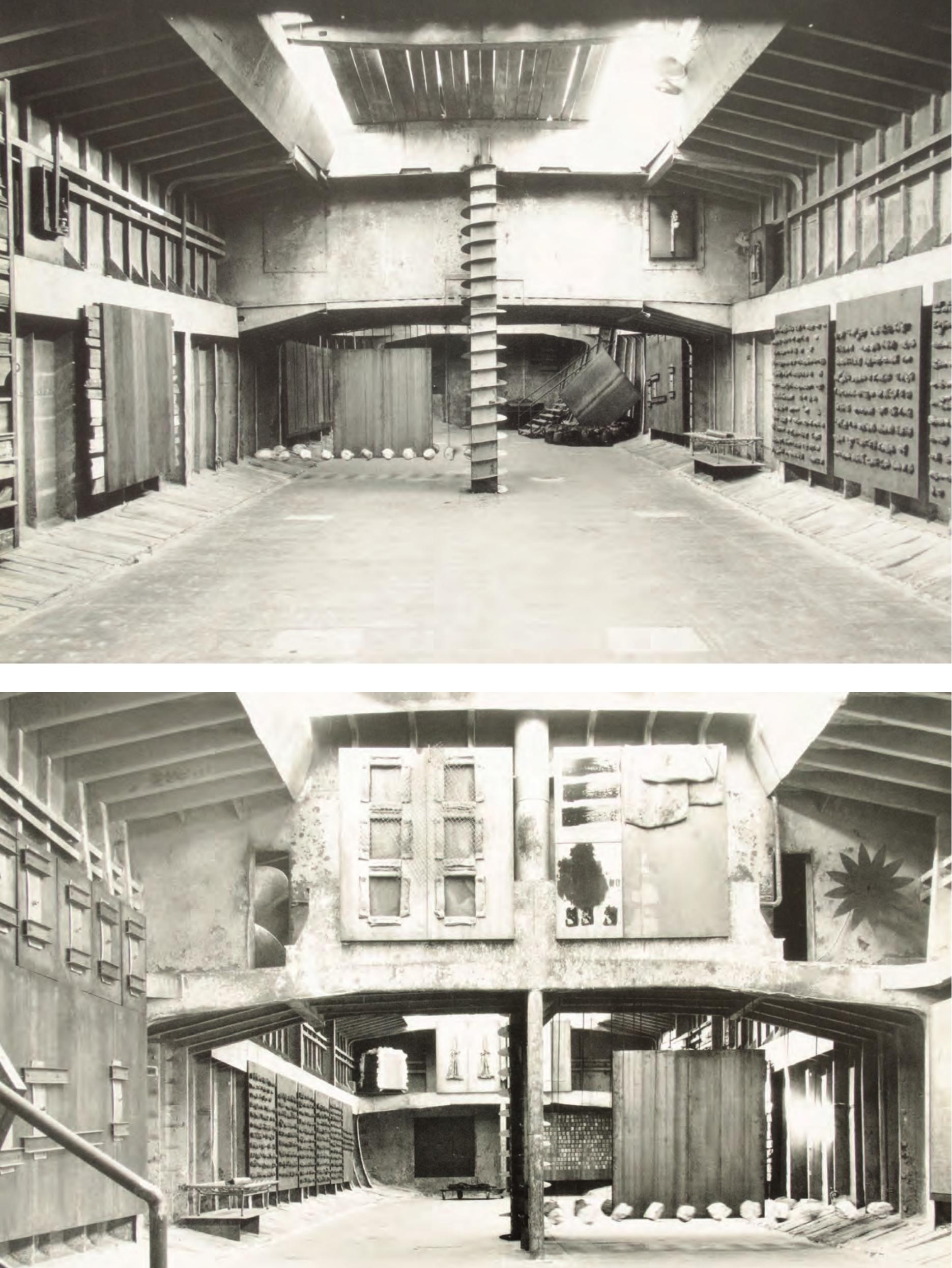


\section{O julgamento de K. 1982}

Publicado originalmente na revista Domus, Milão, n 628, maio de 1982, p. 84-85.

"Prezados senhores do júri, compareço diante de vós injustamente acusado de ter tentado, e este é o meu único crime, mudar o homenzinho das ruínas de Piranesi para o primeiro plano, sem mudar a paisagem."

"Eu tentei essa façanha, embora eu percebesse que a história estava contra mim. Os amigos cujos conselhos eu procurei responderam que não é tarefa de um pintor executar desenhos subversivos."

"Sem dúvida, o homenzinho de Piranesi é anti-econômico em termos do mundo moderno e, com muita honestidade, esta é uma das razões pelas quais eu gosto dele."

"Eu sou culpado de não mais admirar os entardeceres romanos. Estou obcecado com o destino do homenzinho de Piranesi."

“Eu preciso encontrar uma linguagem para ampliar essa pequena figura abaixo das ruínas. Preciso do Cabaret Voltaire. Eu preciso de Montmartre. Preciso dos cabarés em Berlim. Preciso da consciência, do pathos e da visão de Klimt. É claro que, nesta Europa devastada do pós-guerra, é impossível encontrar o tipo de tensão necessária para formular uma linguagem para ampliar esse homenzinho das ruínas de Piranesi."

“Eu sei que meu projeto é revolucionário e é o único capaz de recuperar a integridade de uma imagem de nossa cultura."

"A linguagem do século XX foi formulada de acordo com os centros. Os centros garantem a verticalidade. A abolição dos centros nos levou apenas a um declínio imaginário da qualidade. Também estou sendo acusado por minha busca desesperada de um centro. Mas estou convencido de que um dia o centro me oferecerá a linguagem para ampliar esse pequeno homem nas ruínas de Piranesi."

“Via Emilia leva-me a Londres. A Via Aurelia, para a França. A Via Flaminia, para a Alemanha. Comprei um chapéu em Berlim. Comprei as luvas em Viena. Comprei a lavanda no sul da França."

"Eles têm conversas coloridas comigo, falam comigo sobre os sonhos e

116 Sem título, 1995. Painéis de metal com pedras e vigas de ferro. Vista da exposição Kounellis, La Salara, Galeria de Arte Moderna, Bolonha, 1995. Foto: Aurelio Amendola. a psique, mas em tudo isso não consigo achar a lógica da história para me ajudar a ampliar esse homenzinho das ruínas de Piranesi."

"Eu sou um condottiere medieval em seu caminho para a Terra Santa, onde, sem dúvida, vou encontrar a linguagem para ampliar o homenzinho das ruínas de Piranesi."

O júri se retira. 
O júri retorna.

O veredito:

“Você está condenado a sofrer o destino do judeu errante pelo resto de sua vida."

A voz de uma velha:

"Vá, vá lá, filho, esse é o caminho da glória." 


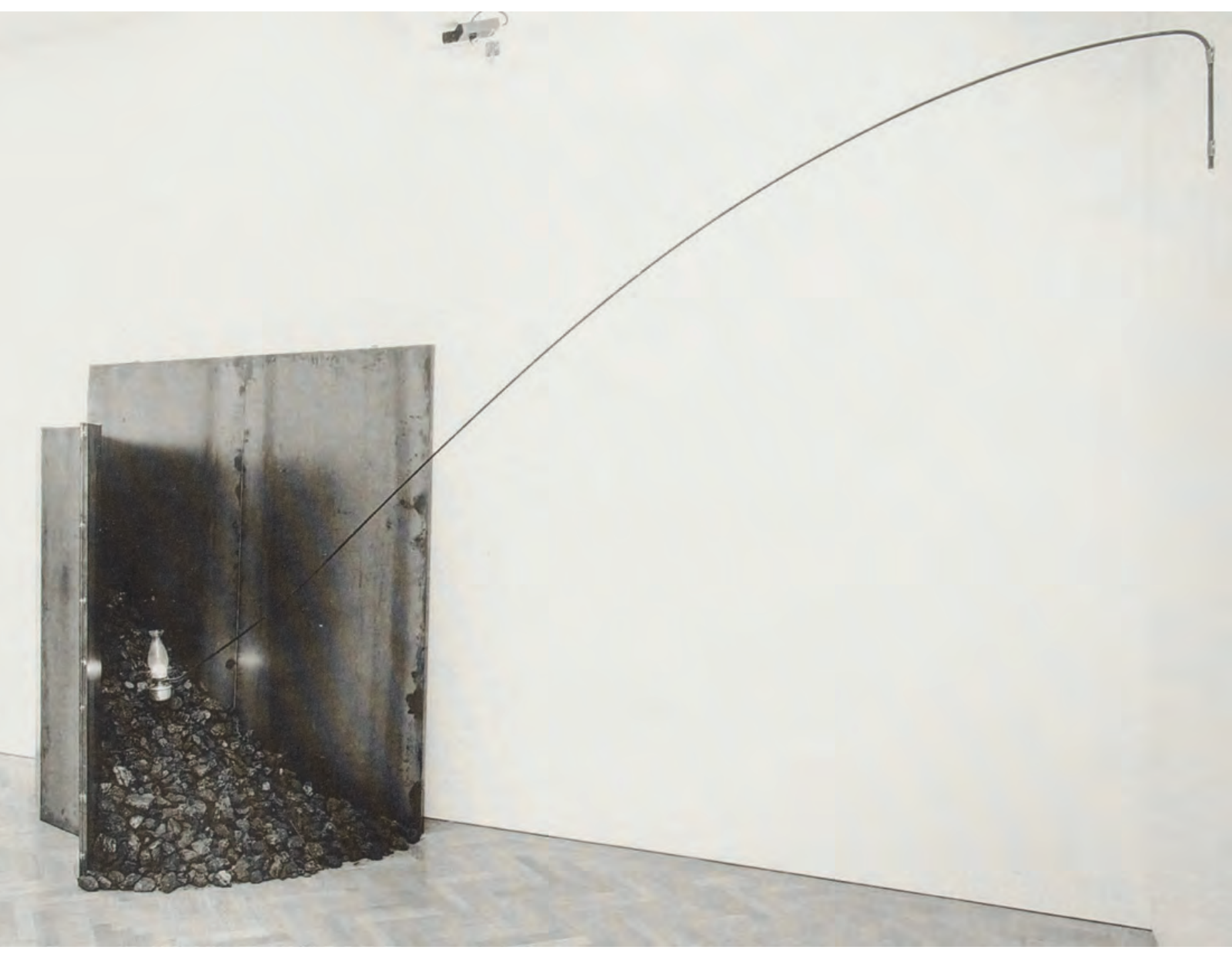




\section{As pinturas negras 1982}

Publicado originalmente em Documenta 7, Kassel: Museum Fridericiam - Orangerie Neue Galerie - Auepark, vol. 2, 1982, p. 182-183.

As pinturas negras

O desejo de desenhar um rosto em um pedaço de jornal

As sombras de uma imagem

A especulação sobre cinza

O Apolo noturno

O artesão da Via del Coronari

A hipótese de um trabalho inacabado

A ética de um trabalho inacabado

A finalidade de um trabalho inacabado

O violão poliédrico

A arquitetura simétrica das tardes

Os fragmentos de estátuas barrocas

A sombra do trem

Finalmente, para ver claramente

Cinza, ocre, verde, uma sombra de Siena vermelho, verde, traços brancos, uma garrafa, um bandolim, a escultura de uma imagem pintada, a plasticidade de uma escultura pintada, a profundidade de um bandolim, a parede decorada, o verde, a umidade da parede, a sombra esculpida, o bandolim, a parede esculpida, o verde do sofá no ocre da parede esculpida, a palmeira na janela da parede esculpida, a mulher na janela, o bandolim, a janela, a palmeira, a parede estofada, o sofá, o bandolim, a janela, a palmeira esculpida, o bilhar marrom, a sombra de uma figura em preto, uma figura em movimento, a pintura importante de um velho braço de cadeira, o púrpura, ocre e verde do braço virado para o torno do sofá ao lado da parede com o bandolim.

A causa justa, ideologia, paisagem, sem traição.

118 Sem título (Carvão), 1967. Estrutura de metal e carvão. $28 \times 155 \times 125 \mathrm{~cm}$. Fotografia: Claudio Abate. 


\section{Foi um sonho ruim 1984}

Publicado originalmente na revista Domus, Milão, $n^{\circ}$ 650, 1984, p. 68.

Nós falamos hoje sobre "pós-" sem causar controvérsias. Isso foi um sonho ruim. Os contornos estão sendo delineados para sinalizar o fim de uma era de aproximações. O obstáculo é - na Itália - que a maioria dos intelectuais são prisioneiros da mídia de massa.

Existe uma lei de consenso que dificulta o processo de renovação... Boccioni? Desde o início, desde as suas primeiras pinturas, desde // Lutto, podemos ver o desejo de renovação do homem e um homem aberto ao diálogo e a mudar...

Boccioni possuía um grande desejo de renovação, ele era um visionário desse amor, essa atração para pintores como Munch. Ele era um visionário e, portanto, alcançou os resultados. A figura de Boccioni ganha uma estatura ainda maior nos tempos em que a busca da identidade - de uma grande identidade cultural nesse ponto - é a redução em um projeto insignificante. E por essa razão eu o chamei de mentor moral. Porque, mais do que qualquer outra pessoa, ele representou um desejo de renovação e enfrentou a história. Sem sucumbir a isso. Muito tem sido dito sobre a necessidade de radicalização, sobre a busca de novos e válidos interlocutores. Americanos, europeus... e sobre a perspectiva de renovação e arte visionária. Um projeto comprometido com o futuro. Esta cultura ocidental nossa, com seus altos e baixos, claro, nos acostumou a fortes tensões. E essas fortes tensões devem durar.

Dialetos? Aqueles que não conhecem nenhuma linguagem não têm problemas com os dialetos. O problema só existe em relação a uma linguagem. Dialetos, em relação ao latim. Sem este tipo de história, o problema é inexistente. Mas ainda é melhor ter esse tipo de história do que... Pegue a América, por exemplo. Quem são os interlocutores americanos? Esse tipo particular de pessoa afligida de problemas com quem é possível conversar. Os artistas de graffiti americanos se inclinam para a sociologia? Eles não estão sozinhos nisso, na minha opinião, pois existem outros na Europa. Mas estes ainda têm uma mentalidade de 1968. Enquanto

120 Sem título, 1967 Carvão e desenho no piso.

Foto: Claudio Abate.

121 Sem título, 1990. Carro de ferro e sacos de juta preenchidos com carvão.

Foto: Claudio Abate. nós, em 1962, 1963, já estávamos prontos para 68, e em 1968 já havia comprometimentos políticos. Não é uma questão do continente, é sempre uma questão de história, de interpretação da história. Criar uma pintura é extremamente difícil sem uma ideia da história.

Americanos. Eles descobrem o fio dourado e depois o abandonam. 
Mudança. O tipo de história de nômade. O medo de que o fio esteja esgotado. Portanto, não pode haver progresso. Enquanto somos exatamente o oposto. Temos revolução, um retorno ao passado.

A questão da citação é um mal-entendido formulado pelos críticos para depreciar o aspecto subversivo da arte. Refere-se a uma interpretação descritiva, literária, sem qualquer ideia de choque visual. É utilizado por uma determinada categoria de pessoas que procuram estabilização. Tudo é ambíguo, pouco claro, medroso, e implica apenas uma mentalidade eclético-burguesa. O que falta é a tensão final que acompanha a história da arte. Um certo tipo de crítica, baseada no idealismo de Croce, que nunca soube realmente qual era a tensão e a visão da arte moderna, e criou esse incrível mal-entendido.

A arte nunca foi considerada como um choque, porque nunca experimentaram nenhum período de arte. Nenhum. O ecletismo é uma maneira de viver uma vida elegante, sem contradições. Ninguém mais quer ser desagradável, então todos se tornam ecléticos.

Arquitetura? Gosto de arte déco, é extraordinária, mas você não pode retomar esse fenômeno de forma decorativa, porque então também descarta a ideologia que o estimulou, sem criar aqueles homens que raciocinaram no sentido social. Você mata tudo.

Você não pode substituir esse eco popular para criar uma visão cenográfica do passado. Eu sei por experiência, que tudo o que você faz dentro de um teatro é, pela força da circunstância, teatral. Portanto, esta não é a tarefa do arquiteto.

Como não há visão moral de um edifício, os cantos e todas essas coisas tornam-se falsas. Um edifício torna-se o exemplo arquitetônico de uma sociedade que não tem mais nada a oferecer. Não há ideia de paisagem, nem ideia da cidade, nem ideia do futuro... O novo museu de Stuttgart é um exemplo dessa arquitetura onde as obras de artistas se confundem como resultado de um desejo de ornamentação.

Dogma. Não é verdade que o dogma não pode ser um aspecto da liberdade.

Precisamos gerar um novo tipo de mentalidade, de contribuições e proporções.

Precisamos de um grupo de pessoas que considere as pessoas difíceis particularmente fascinantes. Essa é uma das considerações. O portador das tensões se sentirá recompensado. Explicitamente. Mas esse tipo de consideração implica um salto de qualidade de uma classe dominante. É questão de agir rapidamente, de não perder tempo, em um estado de necessidade, enquanto tudo parece ser sereno; E não parece que isso seja justificado, mas é duplamente justificado porque não parece ser assim. 


\section{Burri e Fontana 1984}

Publicado originalmente em Odyssée Lagunaire, Paris: Daniel Lelong Éditions, 1990, p. 133.

As obras de Burri e Fontana desempenharam um papel primordial na minha formação, bem como o trabalho de muitos outros artistas dessa geração que basearam suas pesquisas em materiais. Consequentemente, os eventos políticos nos inspiraram a interpretar a história, o que indubitavelmente influenciou nossa sensibilidade e nossa maneira de avaliar o espaço. Isso nos permitiu codificar uma linguagem que, com certeza, explica os problemas históricos e culturais deste país, mas que, desde o início, também teve interlocutores na Europa e na América. 


\section{Omelia 1985}

Publicado na revista AEIUO, Roma, n 12-13, janeiro de 1985, p. 58-67.

Há um amarelo no branco de Malevich porque há um eco de ouro atrás dele.

O aspecto dramático do nosso trabalho (apesar da nossa consciência da tensão do quadrado) reside no fato de que nossa lembrança de Laocoonte ainda está viva.

A ortodoxia leiga de Malevich.

Espaço como o movimento do infinito.

Dogma como ordem composicional.

O eremita como a oposição.

Dor como o caminho para a pureza.

A ausência do Purgatório no conceito de quadrado.

A conquista da liberdade como a busca da realidade e dos limites de uma cultura.

Os limites de um metro.

A transgressão da fé.

As perspectivas da moral e do metro como justiça.

O retorno das pessoas e da invenção formal.

Forma como dignidade e como ponto de encontro.

Forma como poder e oposição.

O pragmatismo como opressão e realidade.

O centro e o andarilho.

O conceito de heresia e de dignidade intelectual em face da conformidade. A relação entre poder militar e credibilidade de forma.

A centralidade de um texto humanista em uma sociedade que prefere a produção em série.

O vasto patrimônio da filosofia e a mediocridade histórica de uma cor sombria. A verdade apaixonada representada por uma comunidade.

124 Sem título, 1980

Estrutura de ferro preenchida com peças de mármore e fragmentos de estátuas de gesso e mármore, e tinta preta sobre o piso. $206 \times 94 \mathrm{~cm}$. Exposição fannis Kounellis: uma retrospectiva em cinco lugares, Museu de Arte Contemporânea de Chicago, Chicago, 1986. Foto: Claudio Abate.
Batalha como história.

Avanços como história.

Povos como história.

Porque eu defendo o direito ao Divino, como um homem do lluminismo.

Melancolia como um projeto.

A melancolia é uma tendência historicamente reconhecida.

A ideologia da perspectiva.

O ponto onde as divindades e os humanos compartilham os mesmos interesses. 


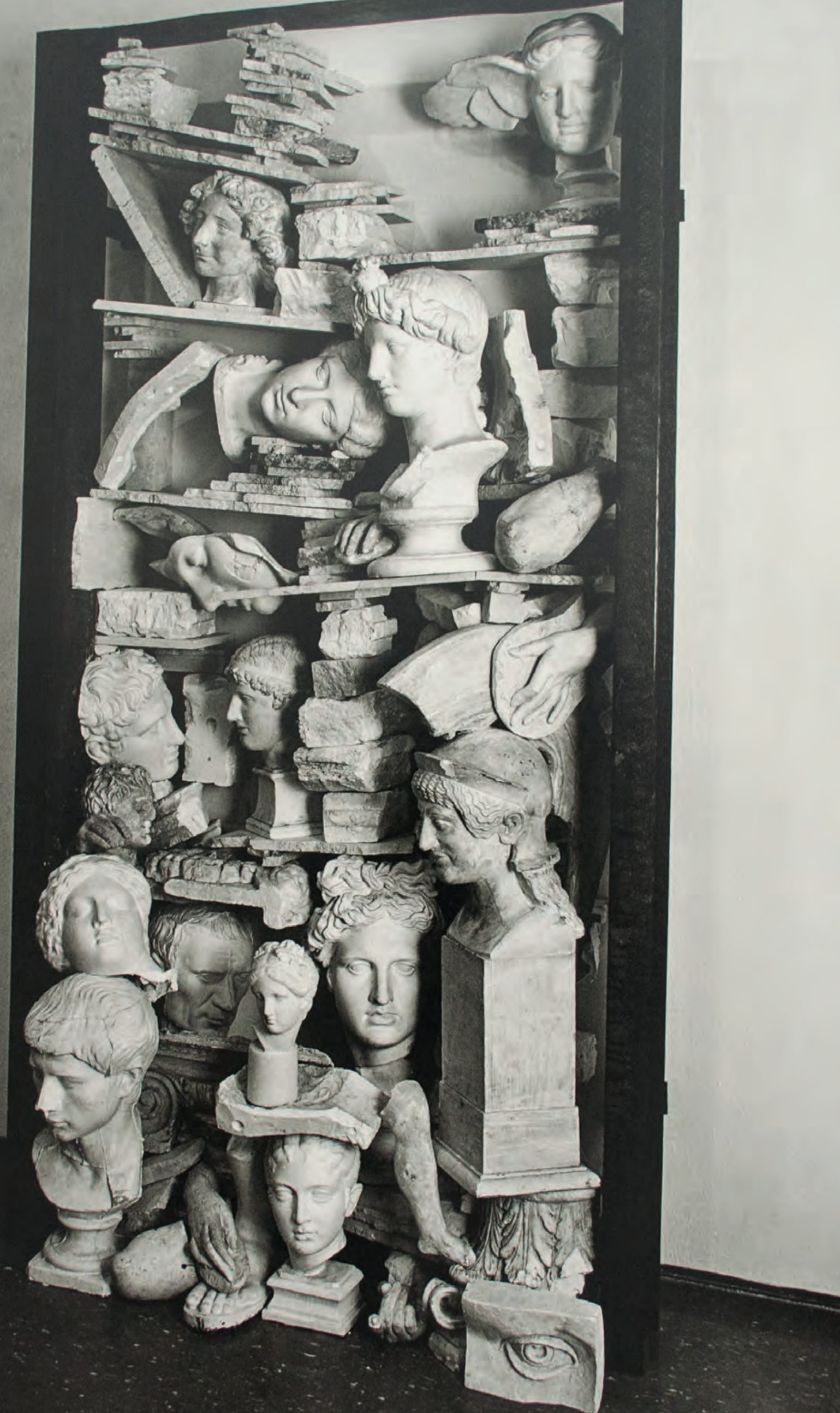


O conhecimento (desde que instilado com a compreensão) amplifica as contradições, então por que tantos daqueles que se veem como produtos do Iluminismo eliminaram as contradições de suas experiências com forma?

Vamos ser francos: somos importantes e só precisamos dar uma forma em um espaço pequeno, mas já sabemos que isso é quase impossível historicamente, então qual é a origem de nossa credibilidade?

A credibilidade vem do domínio da fonte; daí minha serenidade.

Eu sou ideologicamente definido, portanto, eu presumo; e quem me concede a autoridade para fazê-lo?

As passagens através de contradições levam à consciência de um limite, e do conhecimento de um limite brota o conceito de autoridade.

O conceito de tirania e a história de um ponto calibrado no espaço.

A necessidade da tirania como o último posto avançado da justiça.

A justificativa da tirania como um ideal não inflável.

A totalidade como uma ideia do infinito, em termos de sublimidade e presença inconfundível, é a distância mínima para uma discussão gigantesca.

O limite da heresia em uma fé.

O herege como um progressista.

Heresia como ponto de discussão.

Nós finalmente reviveremos um momento em que os hereges serão incongruentes.

É certo que as litanias são atraentes.

As realidades da Rússia pré-revolucionária, incluindo os peregrinos e Teófobo, tinham uma cultura reconhecidamente vital que, hoje em dia, está desaparecida.

O quadrado perdeu seu fascínio e, tendo perdido sua lógica inicial, a coerência estilística não é suficiente para emprestar-lhe credibilidade.

O conceito de laicismo não tem nada a ver com o domínio do pragmatismo.

O centralismo tem uma pungência liberadora e sintética quando compreende e concede amplamente.

Entre uma lógica e outra, há colinas, oceanos, abismos.

Defendo minha lógica em linhas gerais.

A única mediação possível é a solidez linguística de uma obra.

O extremo como incentivo à discussão.

E tudo isso para dizer o que Donald Judd afirma, em sua escrita (apesar de haver, naturalmente, pontos de encontro), revela os defeitos permanentes de certos pintores americanos: sem uma compreensão das motivações populares e uma ideia da história dos motivos da autenticidade de uma forma, uma interpretação das obras continua a ser um fato estritamente

125 Vista da exposição Dodecafonia, Gavin Brown's

Enterprise, Roma, 2016 Foto: Manolis Baboussis. métrico de um ponto de vista formal.

No entanto, isso não diminui o fato de que uma certa experiência pictórica pode ter uma derivação digna, uma recuperação digna e uma queda imediata. 


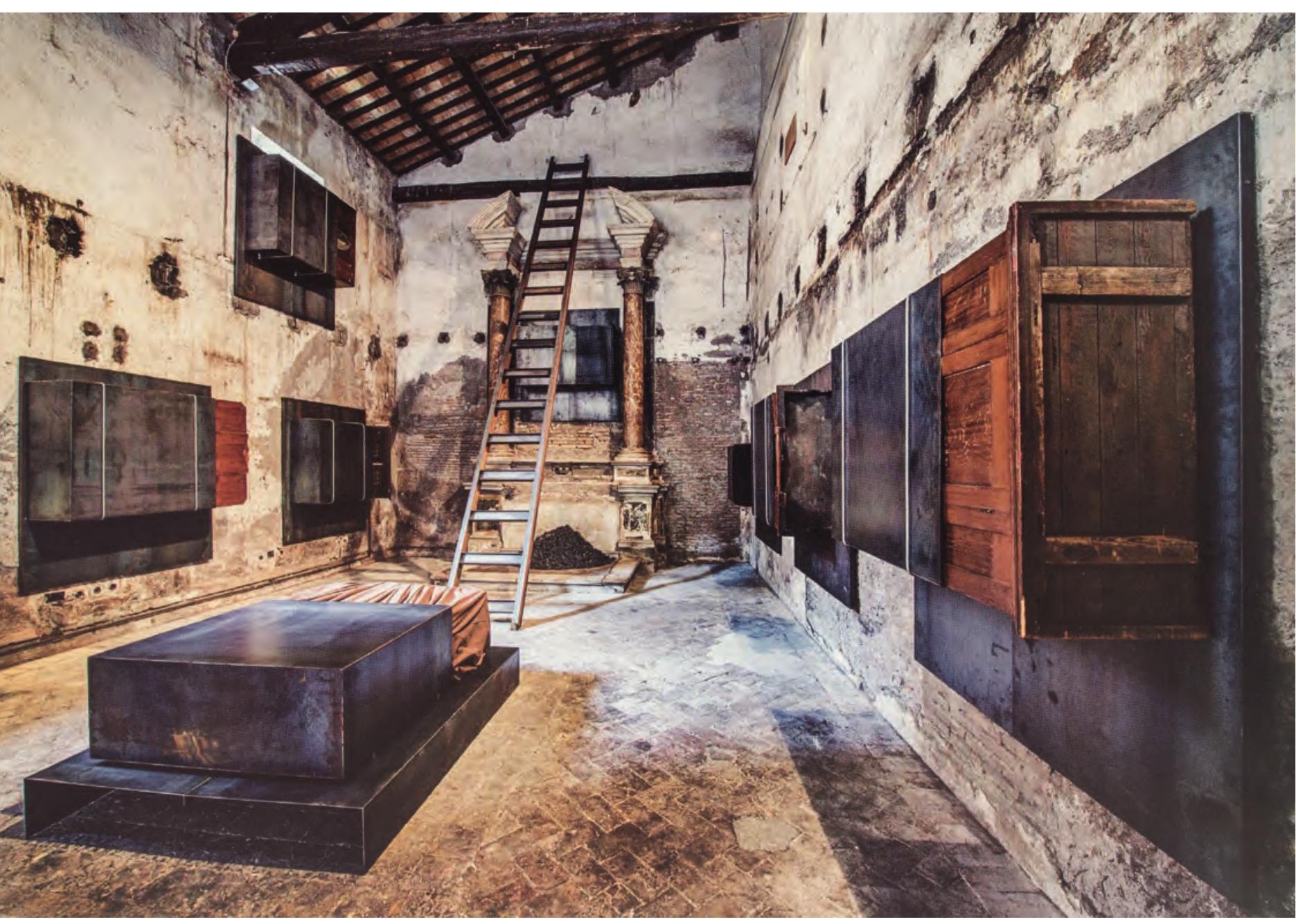




\section{Uma cobra se transforma em besouro I 985}

Publicado originalmente em Odyssée Lagunaire, Paris: Daniel Lelong Éditions, 1990, p. 171.

Atenas, 1985

Uma cobra se transforma em um besouro,

O besouro em um corvo, o corvo em um cavalo árabe,

Mas um cavalo não pode voltar a ser um besouro.

No mundo antigo, metamorfose

Era um elemento constante da história.

A morte, o tempo de equilíbrio

Entre passado e futuro, fornece a medida.

A morte como nascimento da simetria.

Simetria como metafísica. 


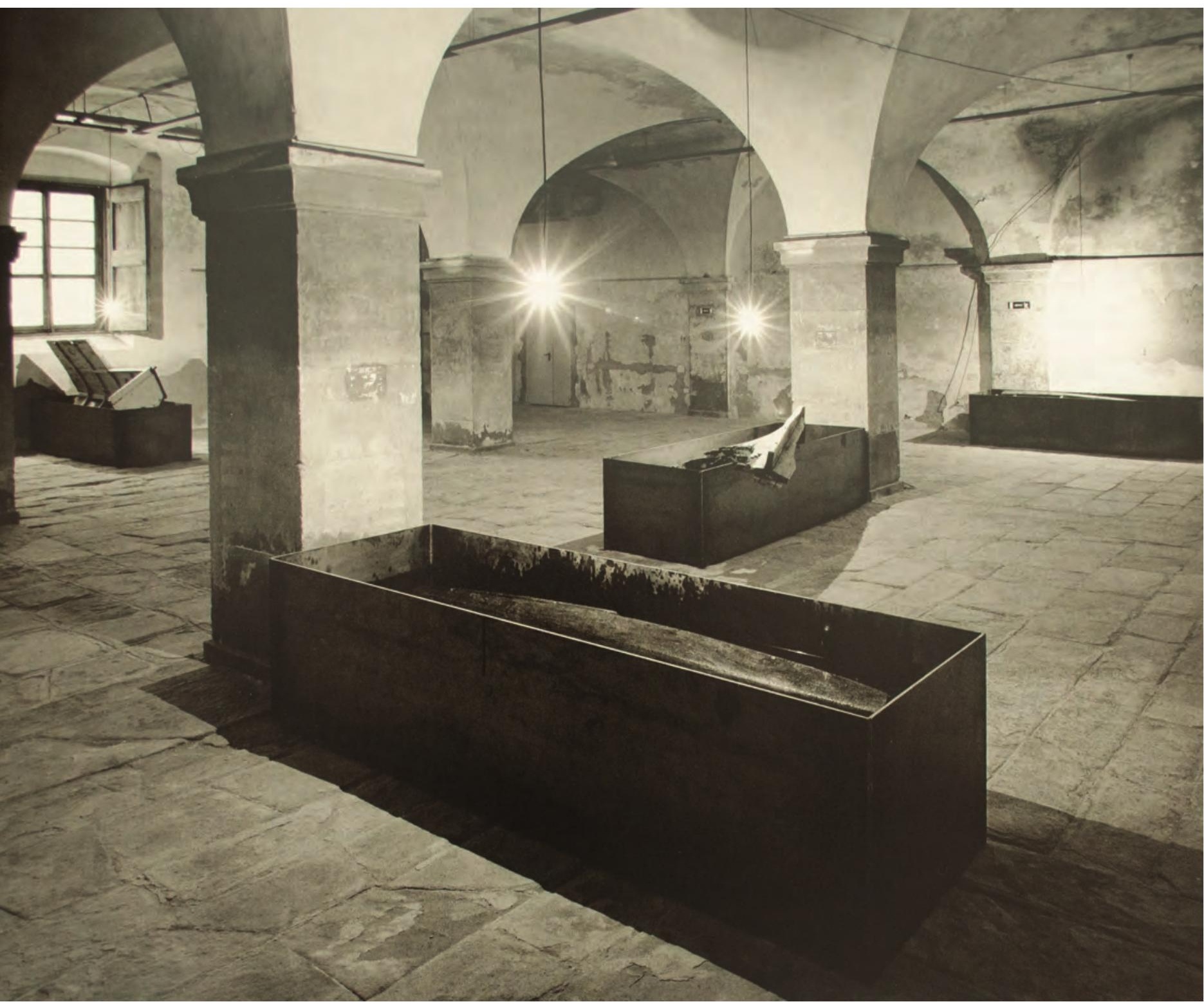




\section{O resultado é o nosso patrimônio formal 1985}

Publicado originalmente em Lo Spazio Umano, Milão, n² 2, abril-junho 1985, p. 4-5, 7-9.

Nós nos prometemos um outro adiamento; mantivemos nossa promessa, semana após semana.

O resultado é o nosso patrimônio formal.

Procuramos descobrir a fonte da renovação, recuperar a sensação e precisão das chamas de La Tour, o sentido da imagem para prometer uma aventura.

O funeral é o seu ponto de partida, a sua identidade cultural, como uma redescoberta ao longo de um longo período de esquecimento devido ao declínio e à submissão.

A linearidade formal da procissão fúnebre, compacta em face do sofrimento, os gestos codificados, os cabelos bem arrumados, os rostos alinhados, os olhos escuros, as mãos intensas, o passo certo, as coroas de flores, o caixão na carruagem, as lágrimas, o grande desejo de um futuro civilizado e cultuado.

Nós começamos com esse fim, o que realmente é um começo para a compreensão de pinturas, arquiteturas e textos escritos. 

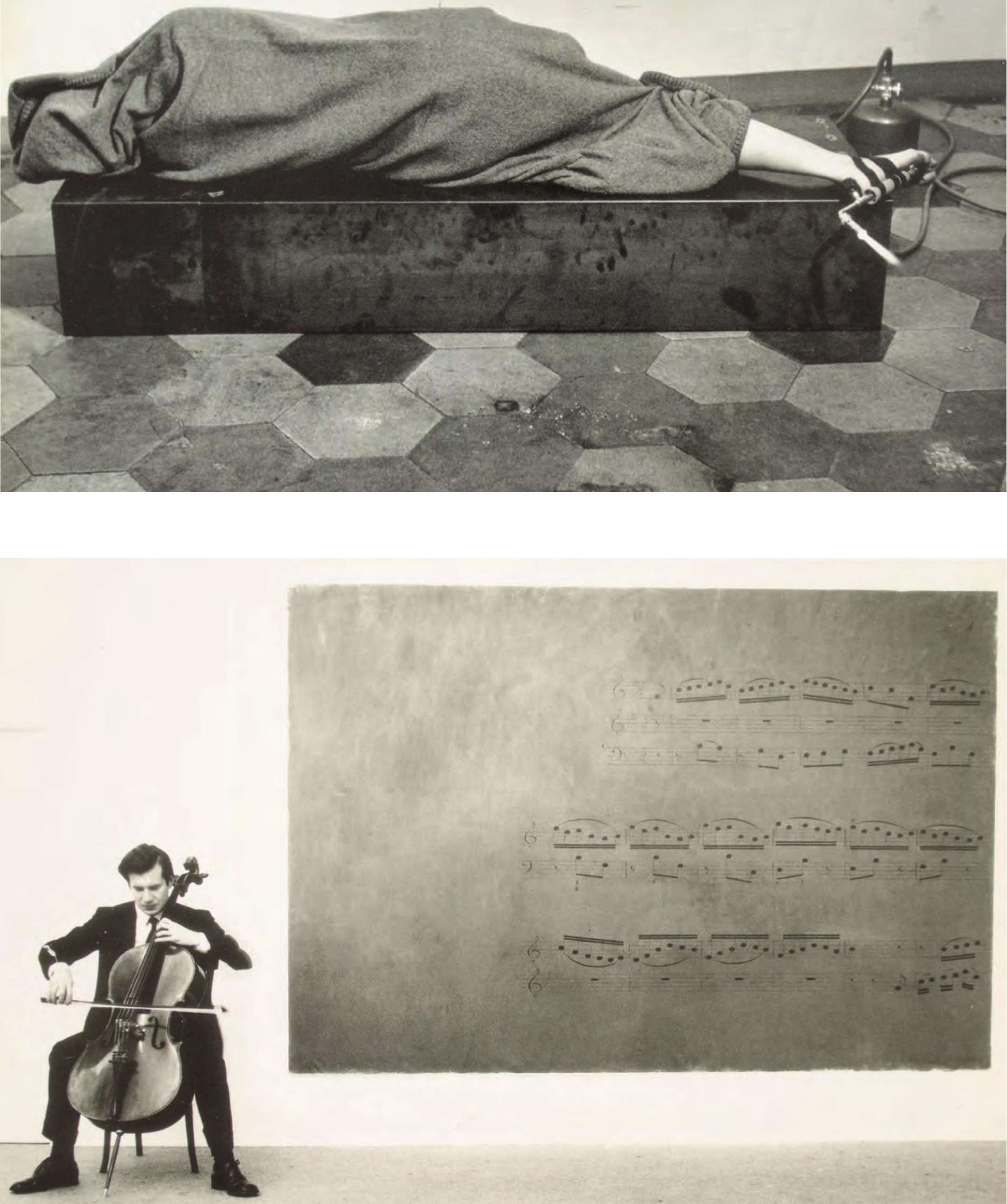

$$
\begin{aligned}
& \cdots \cdots \cdots \cdots \\
& \cdots \cdots \cdots \cdots \cdots \\
& \cdots \cdots \cdots \cdots
\end{aligned}
$$




\section{O que eu mantenho é uma velha ideia 1987}

Publicado originalmente em Jannis Kounellis, Roma: Galleria Sprovieri, 1987.

O que eu mantenho é uma velha ideia, medidas; as medidas de uma folha de papel, um metro por 70 centímetros, e de uma cama de casal e das paredes de uma sala e de uma porta.

O mesmo espírito de encorajamento exclamado com "Viva Marat, Viva Robespierre" em 1968, agora é concedido à redescoberta de uma imagem aparentemente "equilibrada" com a história, sem trair a ideia de que o peso expressa uma beleza justa.

Eu desejo insistir no absoluto, apesar de os leigos preferirem o valor de uma barra de sabão.

Como especialista, desejo propagar a perfeição das peças fundidas feitas a partir de cera.

E tentar que você veja uma mudança formal de eventos que preservam do passado o amor pela viagem, sem negligenciar os esforços feitos pelos pintores italianos da era da pós-guerra. 

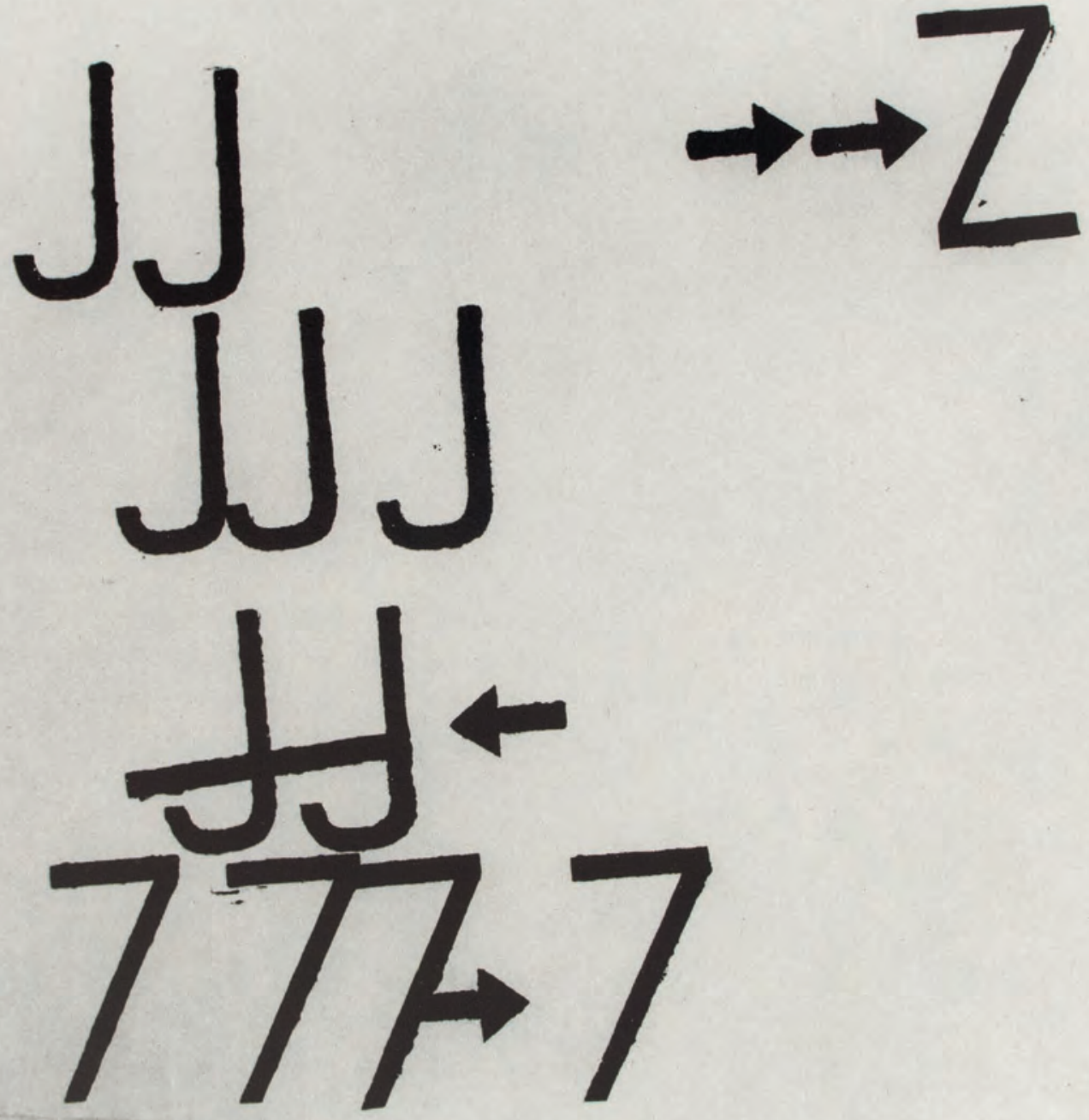


\section{Eu nunca matei ninguém, mas estou disposto a fazê-lo I 987}

Publicado originalmente em From the Europe of Old, Amsterdam, Stedelijk Museum, 1987.

Eu nunca matei ninguém, mas estou disposto a fazê-lo se o meu direito à liberdade for comprometido.

Eu não pedi emprestado fragmentos linguísticos, a não ser por necessidade.

Eu não desejei possuir nada além de coisas bonitas.

Eu medi a distância do objetivo.

Eu vi o sagrado nos objetos comuns.

Eu acreditei no peso como a medida justa.

Eu gostei de frases que indicam a virgindade como o estado ideal.

Eu andei caminhos difíceis, no fundo da floresta, em direção às montanhas.

Chumbo; cabelo; nuvens; Ursa Menor que indica o Norte; vento.

Eu sou incapaz de viver fora do labirinto da linguagem.

Eu amo oliveiras, vinhas e trigo.

Desejo o retorno da poesia com todos os meios disponíveis:

Através da prática, através da observação, através da solidão, através das palavras; através de imagens; através da subversão. 

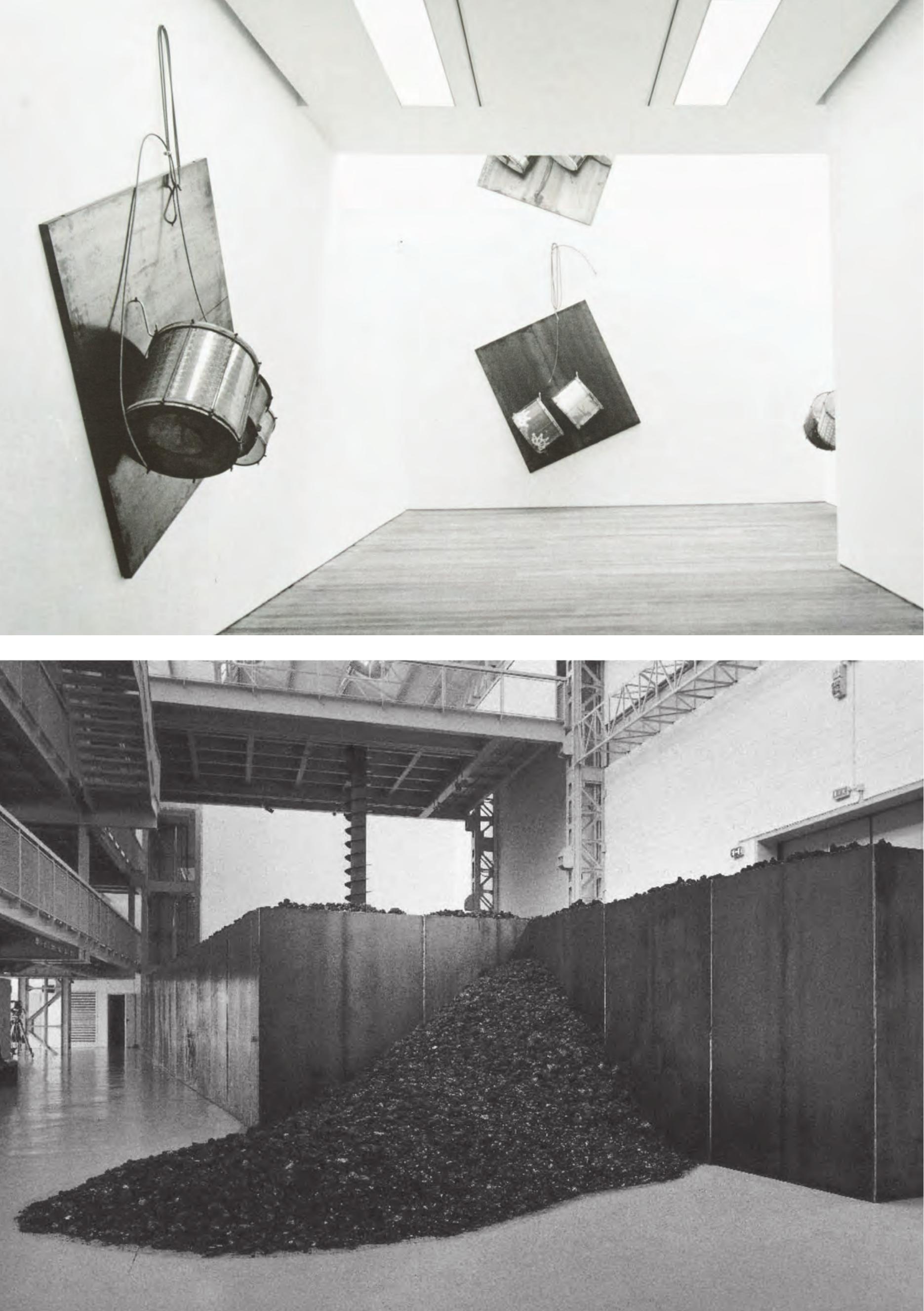


\section{Projeto para Artforum I 988}

Publicado originalmente em Artforum, New York, n 7, março 1988, p. 123-125.

Se a casa é quadrada, é porque o quadrado é absoluto.

Se a porta tem as dimensões humanas, é porque as pessoas passam por ela. Se o desenho de uma cidade é orientado para o Oriente, é porque se refere ao nascimento do sol.

Se os cantos de uma casa tendem a ser verticais, é porque as árvores estão sujeitas à mesma tensão.

Onde fica a beleza em uma lata de cerveja? Como é diferente de uma pintura de Ticiano?

E a nossa própria era? Por que a nossa própria era se identifica com uma lata de cerveja? Eu quero estar livre da arrogância impossível do passado, portanto, amo essa lata de cerveja insignificante, mas sou realmente livre? A característica de uma lata de cerveja é que é repetida um número infinito de vezes, enquanto uma pintura de Ticiano é única. Portanto, eu me identifico hipoteticamente com a lata de cerveja e a repetição necessária.

Mas o que eu perdi da minha própria integridade, da minha própria e profunda natureza cultural, me identificando com a lata de cerveja que pode se repetir, para existir, um número infinito de vezes?

Então, o drama reside em ter amado uma lata de cerveja, sabendo que isso é inconsistente dada a profundidade de uma pintura única.

Se a janela enquadrar uma paisagem, o visionário acentua seu significado enquanto durar a visão.

Portanto, essa lata de cerveja perversa, tão profundamente amada, não é adequada para mim.

Eu devo adotá-la com significados que a tornam aceitável para meus olhos, acostumados com o ser de uma paisagem estratificada.

Então, o que eu adiciono a essa lata de cerveja, e o que removo dela?

Eu adiciono uma visão do tempo que leva em conta o passado, e retiro uma parte de sua natureza, sua repetição. Desta forma, eu torno-a única e, pelo menos, recupero minha própria independência cultural e equilibro-a com a pintura de Ticiano.

A partir dessa pilha de carvão, eu sabia que estava condenado à morte e tentei me salvar.

132 Sem título, 1994. Ferro, madeira e sino. Foto: Aurelio Amendola.
Isso pode ser uma merda; isso pode ser sem sentido; isso pode ser uma invenção diabólica para me fazer de tolo; isso pode ser tão perverso quanto uma prostituta; isto pode ser uma invenção capitalista; isso é 


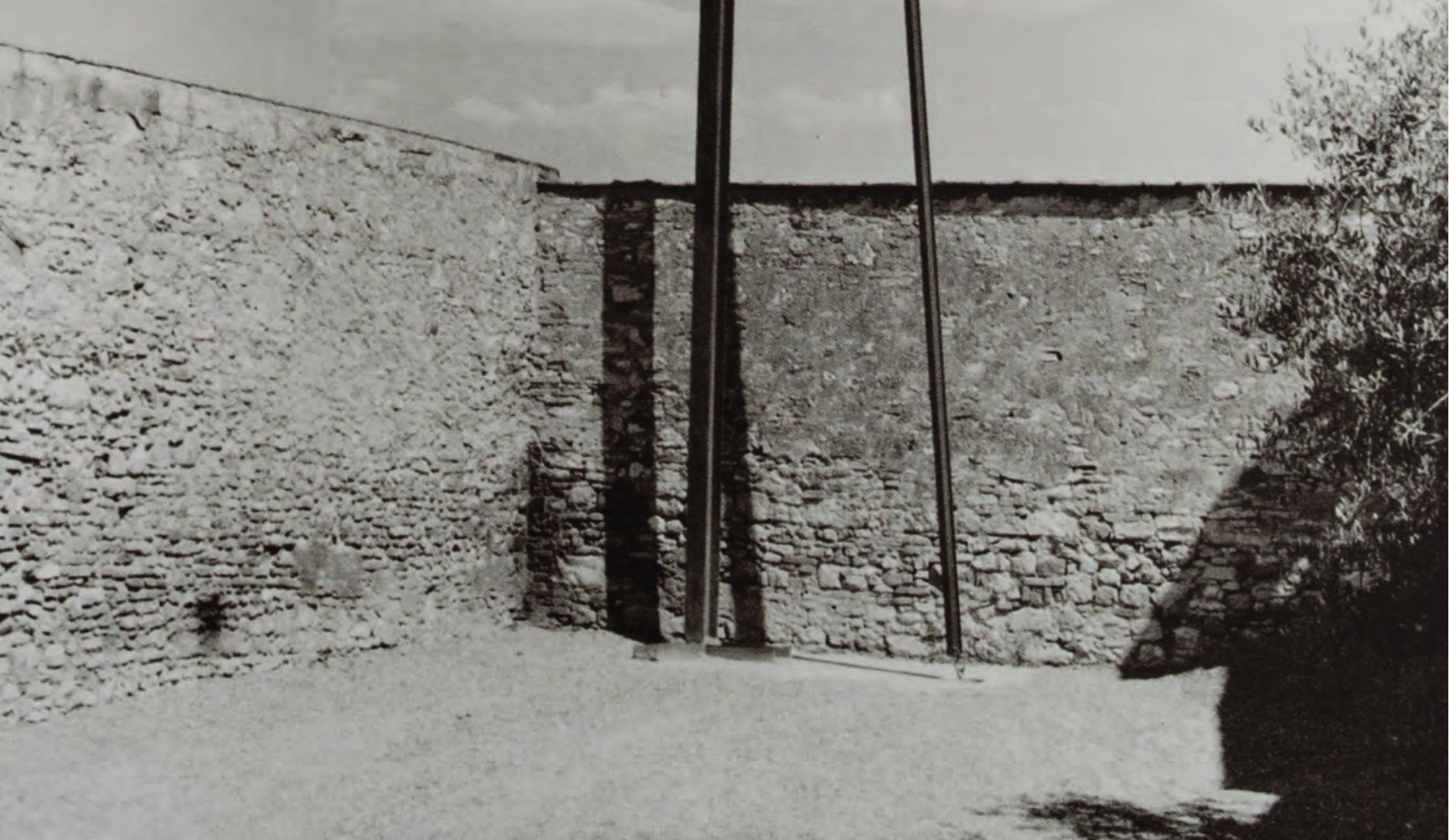


possível, é opressor; contudo, adorei isso por muito tempo, mesmo sabendo que ele deixa de existir quando comparado com um trabalho do passado, com as gigantescas muralhas da cidade de Micenas, com as dimensões de uma porta, com as dimensões de uma cama, com o enigma de uma pintura simbolista, com a feliz realidade de uma opereta. Minha mãe é Ítaca; minha juventude é Ítaca; minha idade é Ítaca; minha morte é Ítaca.

Então, o que a lata de cerveja pode representar?

Os motores a vapor são tão numerosos como uma lata de cerveja.

As máquinas de costura Singer são tão numerosas como uma lata de cerveja.

Os chapéus Borsalino são tão numerosos como uma lata de cerveja.

Os sacos de café, que marcaram uma era inteira, são tão numerosos como uma lata de cerveja.

As camas em uma enfermaria são numerosas.

Os cartões de identidade são numerosos.

As listas de prisões são numerosas.

Os copos de bar são numerosos.

Os jornais são numerosos.

Portanto, na minha ânsia de viajar, adoro a lata de cerveja porque se parece com uma máquina a vapor; mesmo sabendo que nunca representará a universalidade que uma obra do passado infunde em mim.

Um bilhete para a viagem de trem da Colônia para Berlim custa 15 latas de cerveja.

Um Volkswagen custa 13 mil latas de cerveja.

Um cavalo de corrida custa 2.000 latas de cerveja.

Um apartamento custa um milhão de latas de cerveja.

Um par de sapatos custa 100 latas de cerveja.

Um sobretudo custa 500 latas de cerveja.

Uma tela de um pintor novato custa 2.000 latas de cerveja.

Aprendi que as obras em que uso lã, nas quais ecoam aquela Arcádia perdida, fora do tempo, podem ser adquiridas pelo equivalente a 150 mil latas de cerveja.

Ítaca! Ítaca visionária!

Duas guerras mundiais foram travadas para que essa lata de cerveja possa finalmente ocupar um lugar privilegiado no meu coração.

Nós matamos o rei e, com ele, tudo o que é sagrado.Assim como pretendemos, o laicismo triunfou, como é justo. Mas é impossível não sentir a falta de espiritualidade representada por uma estatueta negra.

Se uma lata de cerveja pode viver ou morrer depende de se a arte vive ou

133 Sem título, 1968 Madeira, corda e trapo. $250 \times 200 \mathrm{~cm}$. Foto Claudio Abate. morre. Portanto, contra o vento em direção ao porto aberto à harmonia e ao paraíso, embora consciente de que o tão desejado e justo destino está muito distante. 


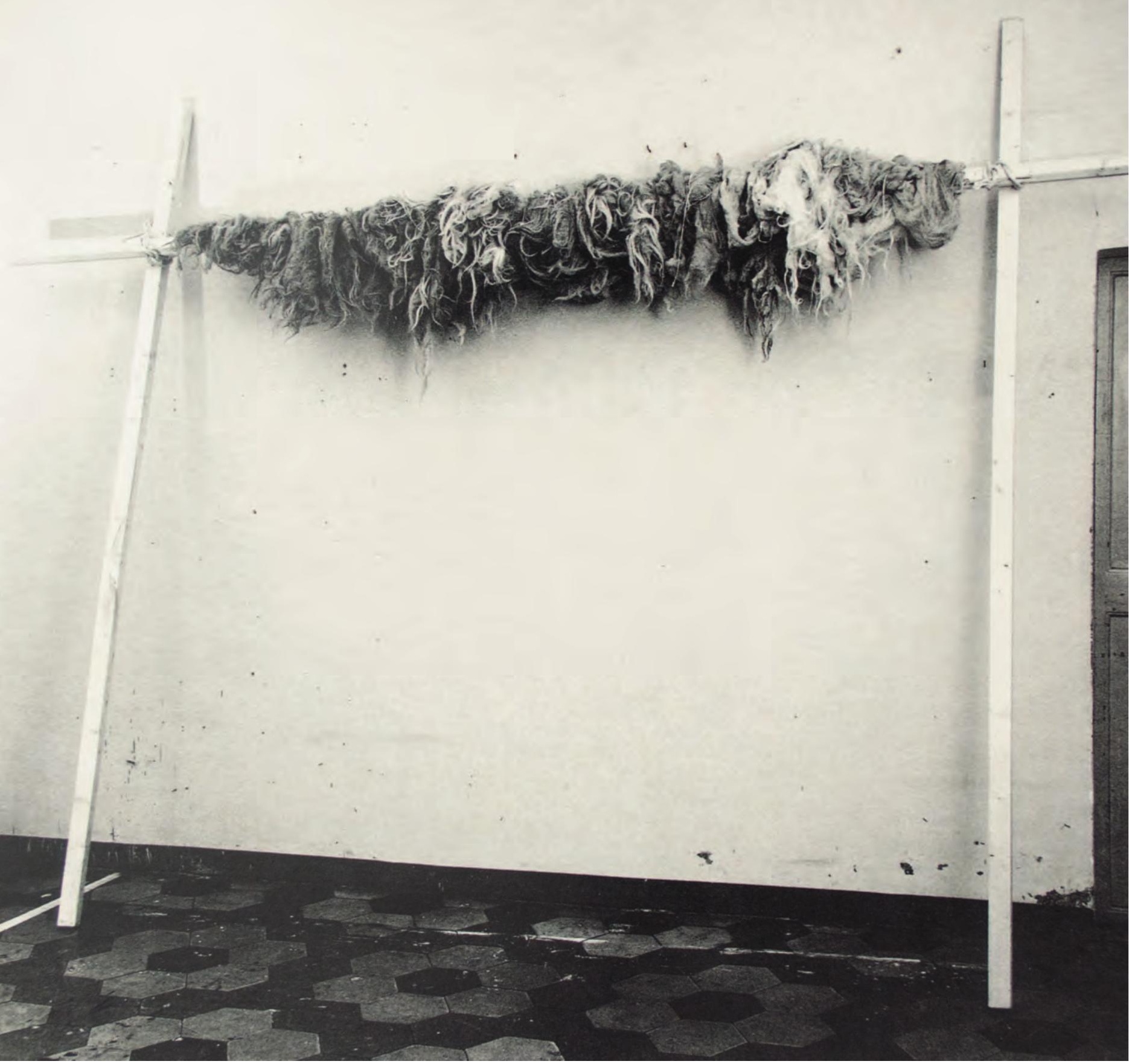




\section{A terceira janela do segundo andar do Palazzo Farnese I988}

Publicado originalmente em Charta, Milão: Palazzo Reale, 1988, p. 212-213.

A argila é matéria, o ferro é matéria, o papel é matéria. Tudo é matéria. O conceito de matéria precisa ser estendido; matéria a ser moldada, matéria que adquire significado, matéria que se torna pungente. Cem quilos de carvão, não plástico pintado de preto como o carvão, e não uma medida de peso abstrata. Um peso é o que oculta, a sua história, a sua moral. Para o artista, 100 kg de carvão é a história moral de uma estética.

As coisas se tornam mais reais, mais genuínas. Genuínas no sentido moral e não em termos de imitações, citações ou obviedades. Um truísmo é sempre falso e até o concreto pode ser bastante irreal.

A matéria assume um significado descobrindo a forma da natureza do material e as exigências que ela faz. Em outras palavras, o que você pode fazer com ela em um contexto cultural. Exigências linguísticas, pois nem tudo é permitido.

A possibilidade de fazer coisas mais reais e genuínas depende da relação com a tradição. A verdade de algo está em seu relacionamento - às vezes até simples, elementar - com a tradição. Tradição, não exemplos ou citações. A tradição possui alguns aspectos extremamente vastos e não pode ser situada. Uma tradição situada pode ser explorada politicamente. A tradição não significa exaltar o passado. Em vez disso, é necessário reorganizar os eventos para adquirir uma realidade presente, não um equívoco. A credibilidade nasce da elaboração dos valores inerentes a um trabalho no tempo presente. Você oferece uma ocasião para interpretar, para ver a tradição.

Visão e tradição: a tradição é visionária. O método para interpretála, adotando-a, é visionário. Não existe tal tradição. Todos os grandes visionários são intérpretes apaixonados da tradição, portanto, das medidas. O homem é a medida pela qual medir, e a medida deve ser sempre a da humanidade, a compreensão ou a concepção do que significa ser humano. Uma nova medida concede uma nova humanidade, e a tradição é a tradição de eventos humanos, não sobrenaturais. O potencial de

134 Sem título, 1992 Estrutura de madeira e ferro com saco contendo mobília antiga. Aproximadamente $36 \mathrm{~m}$ de altura. Foto: Victor E. Nieuwenhuijs. sobrevivência de uma forma depende da extensão de sua adoração. Esta é uma nova interpretação da tradição, própria, e é, portanto, estendida a outros. A tradição tem aspectos amplos, não pode ser situada e não é um fator regional. 
É necessário eliminar o máximo possível, mas nunca completamente, caso contrário, corre o risco de uma estética internacional inexistente. Ser curioso, amoroso, para poder compreender os sinais de uma tradição, a vastidão do fenômeno. Se você insiste em ser de outra forma, você estende a ideia de amor, sobre a qual a possibilidade de recuperar a força, a importância e a profundidade de uma forma depende, em todos os lugares, de certificar-se que você não perca o seu caminho e acabe jogando com estilos.

As bases da operação devem ser bem fundamentadas, ou então você se perde, você não é mais um interlocutor. Você não pode ser um turista na arte e no amor. Generoso, revolucionário talvez, mas nunca turista.

Isso deve ser ordenado, inserido em um código - até mesmo um código revestido de ferro -, caso contrário, você arrisca a aproximação e sua abertura inicial torna-se sentimentalismo, perdendo todo seu significado potencial. Abertura mental, tensão, mesmo em momentos de grande crise, uma aceitação de redescobrir o que provavelmente se afastará amanhã.

A conservação não significa mumificação. A conservação é um fator ativo, não decadente. Não há como conservar outras coisas além de elevando seu nível, ao não aceitar as regras da decadência e, em vez disso, tentando um caminho mais alto. Os meios de hoje não estão equilibrados e aquela grande qualidade do que é pintado não pode mais ser recuperada, nem pode ser preservada como um "bem ambiental." A pintura não é um bem ambiental, e deve ser redescoberta e preservada dentro de uma linguagem que faz sentido mais uma vez. Não pintar, hoje, significa pintar em dobro.

A terceira janela no segundo andar do Palazzo Farnese é o meu credo. Eu não tenho outro. Mas é o suficiente para me fazer um interlocutor internacional. É impossível para mim trabalhar para além dessa janela: para mim, é um requisito. Há aqueles que acreditam no Evangelho. Eu acredito nessa terceira janela no segundo andar do Palazzo Farnese. Isso me dá força para alcançar meus trabalhos. A janela é uma ideia da mesma maneira que uma porta é uma ideia. Ideia, invenção, não uma "inovação", ou uma antiguidade remota. Não existe uma "novidade". Isso Ihe conferiria um papel menor na história do pensamento. Um estilista pode ter esse papel, mas não um pintor, nem um poeta.

Você tem ferro para mostrar o papel. Um trabalho de papel também poderia ter sido uma solução. Teria sido um trabalho descritivo em vista do tema geral, arriscando-se a permanecer um trabalho pobre, diminuído

135 Sem título, 1968 Madeira e trapo. $250 \times 360 \mathrm{~cm}$. Foto: Claudio Abate. em relação ao resto, o principal assunto exibido, para representar com sucesso a "continuidade" e o desenvolvimento do papel, você teria que tomar uma questão preexistente. Por outro lado, não há telas 
fit

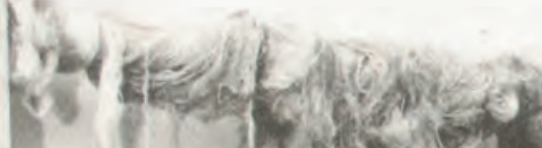

1.

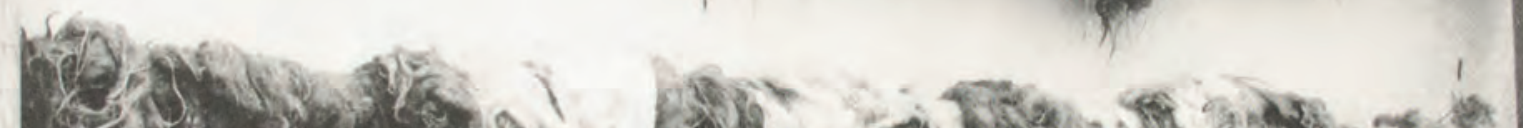
4.

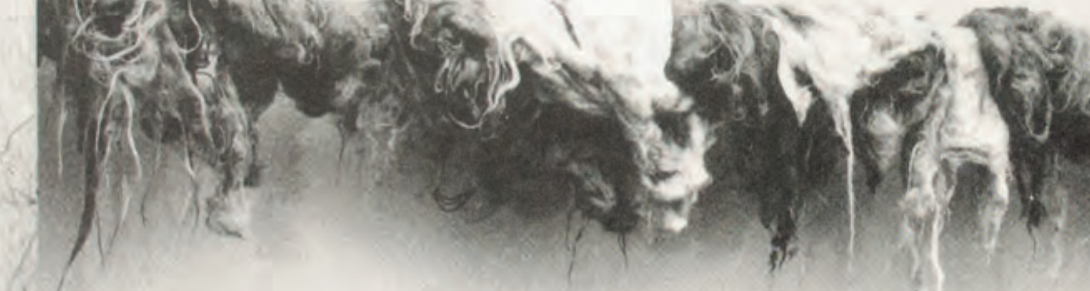

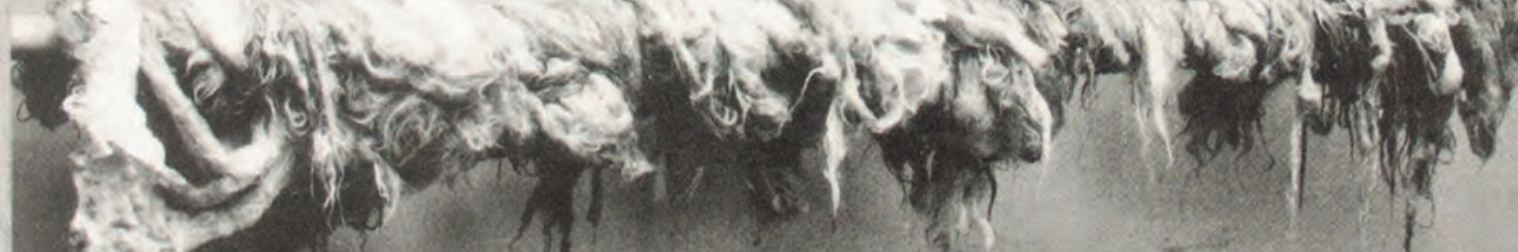

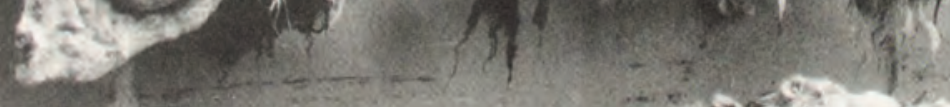

4 (19.

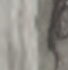
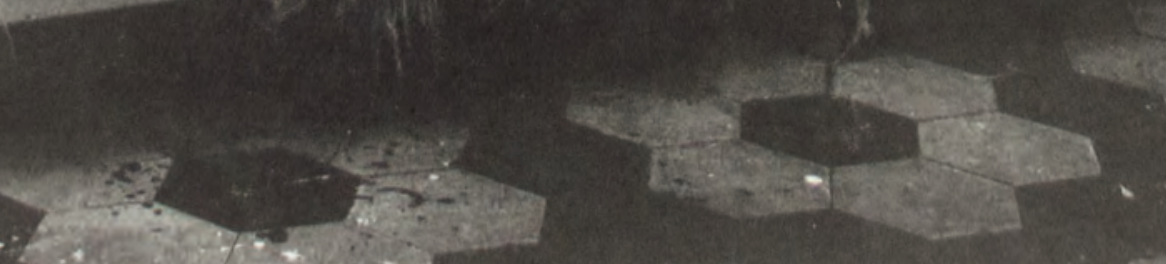
tradicionais sem pintores, publicações sem escritores e assim por diante. É necessário considerar o ato de exibição e mudar seus termos, com um trabalho. Encerrar uma exposição significa emprestar uma dimensão à própria exposição.

Você tem ferro para mostrar o papel, um conceito de ferro ligado ao século passado, algo que já não existe. Você "usa" a partir do momento em que não existe mais. Você volta a esse assunto que perde sua tensão pragmática e se torna mais maleável, pode ser tocado, dobrado como papel. A escolha de cada artista implica valores diferentes. Minha resposta já existe na solicitação para eu fechar esta exposição com um trabalho, e não pode ser outra. 

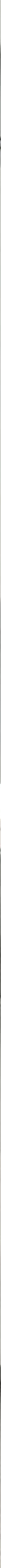


\section{Sobre o tema dos retratos 1990}

Publicado originalmente em Sul tema Ritratto, Roma: Galeria dell'Oca, 1990, p. 16.

É verdade. Fui eu que, na sexta-feira, 26 de março de 1936, por volta das 9 horas, assassinou o marinheiro em guarda na escotilha da popa da corveta, gloriosamente chamada Agamenon, num rompante de loucura e desejo desesperado de me apropriar do navio e escapar. 


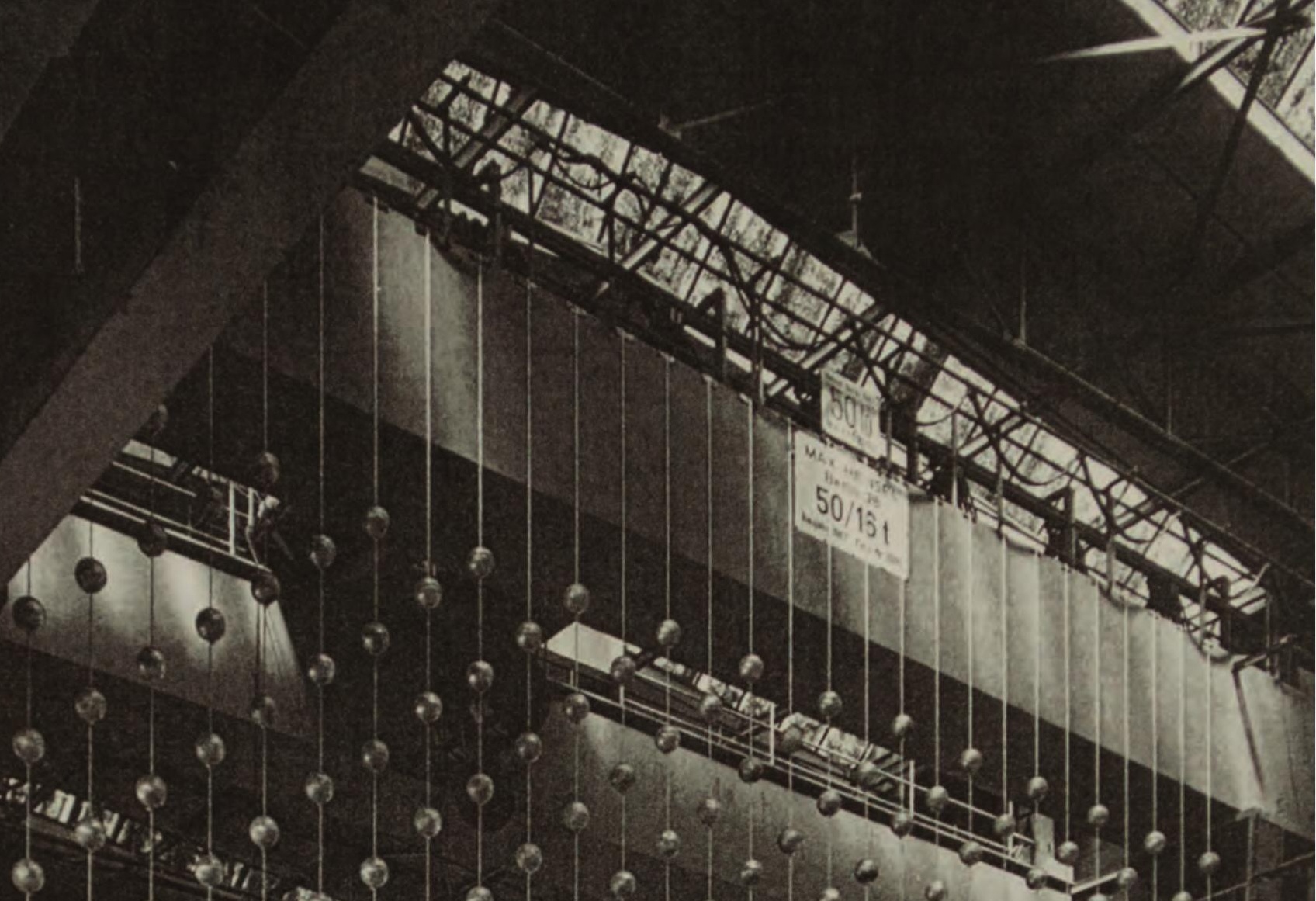

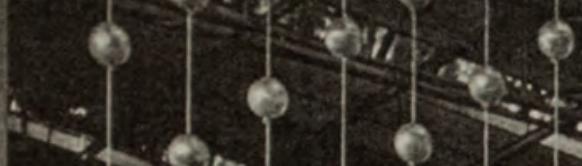

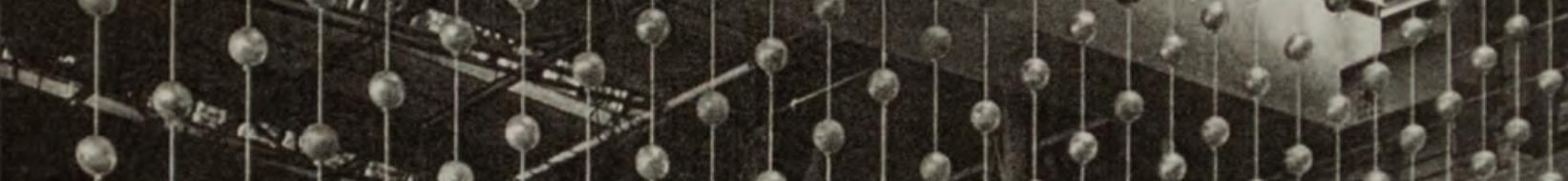

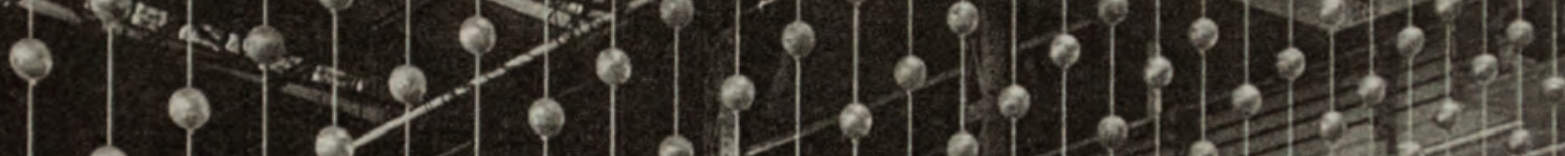

$9\{0$ ?

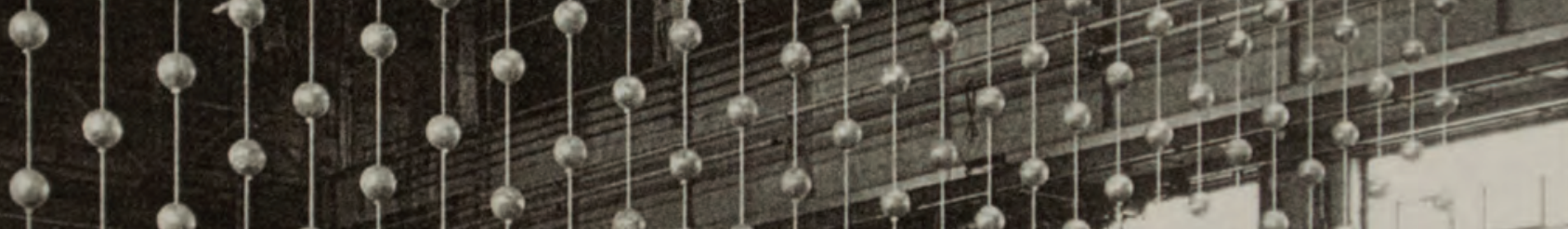

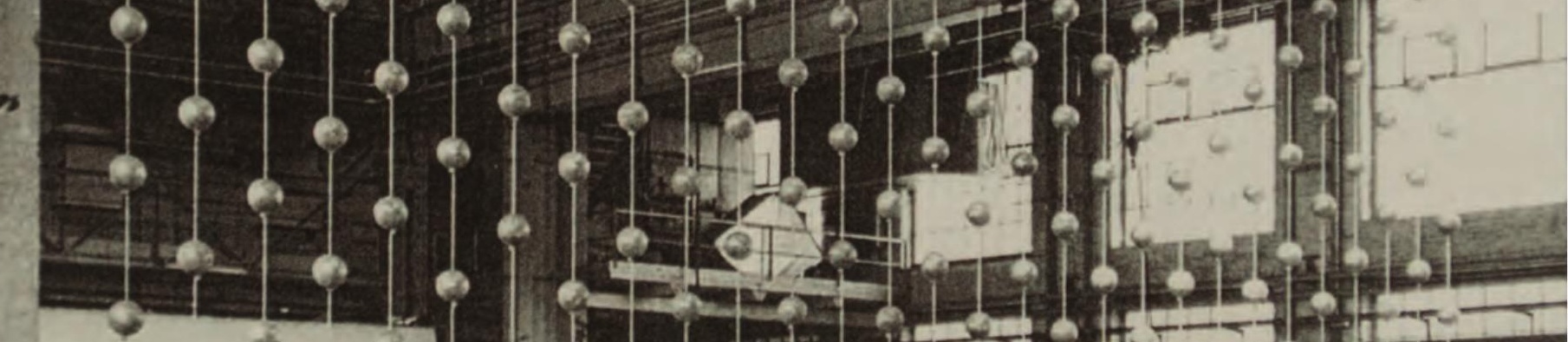

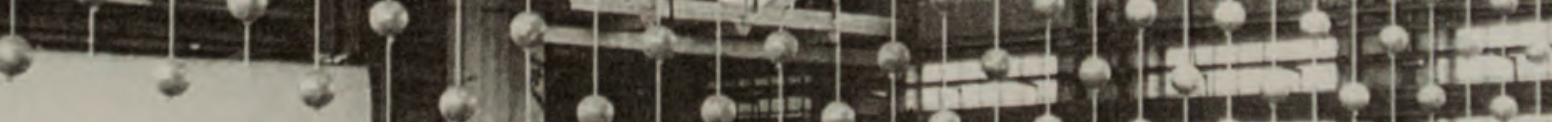

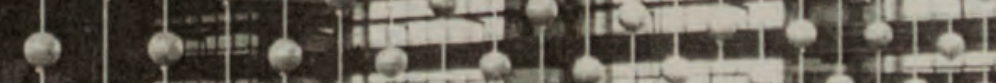

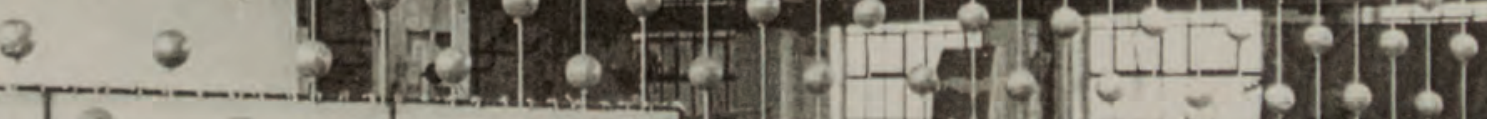
$4\left[\begin{array}{lll}3 & 3 & -2\end{array}\right.$

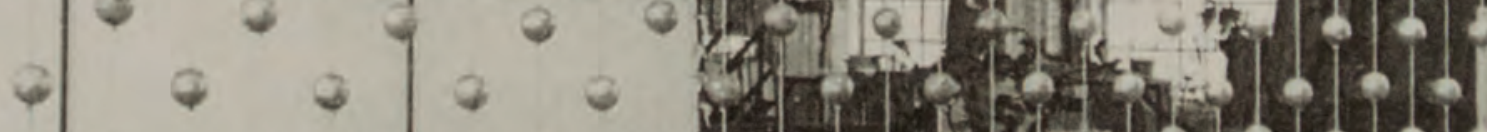

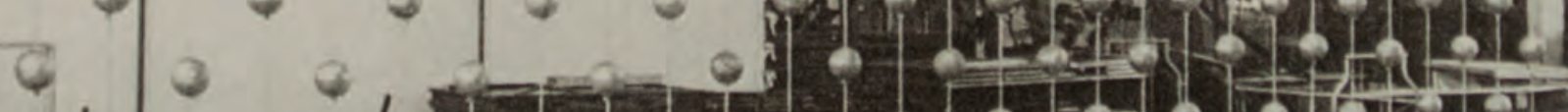

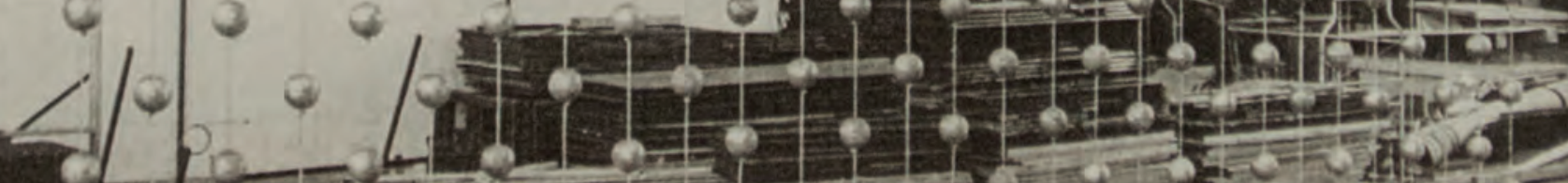

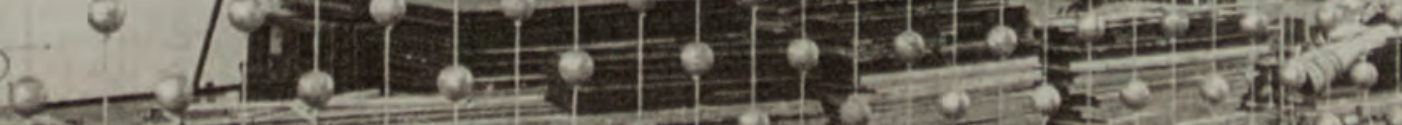

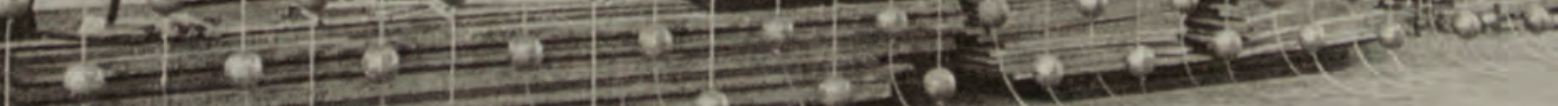

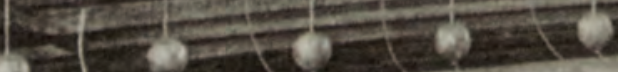




\section{Berlim I 990}

Publicado originalmente em Die Endlichkeit der Freiheit, Berlin 1990 - Ein Ausstellungsprojekt in Ost und West, Berlim: Hentrich Verlag, 1990, p. 146.

O trabalho está instalado na antiga usina elétrica, em ruinas e abandonada, no $n^{\circ} 8$ da Grotewohlstrasse, logo após a fronteira que dividiu a cidade. Reativando uma antiga linha de trem que ligava os dois blocos do edifício, não muito distantes um do outro.

Meu trabalho consistiu nessa reativação.

O segundo trabalho é imaginado na frente de uma casa de classe média na Fasanenstrasse: uma viga de ferro vertical que se levanta até a metade das janelas mais altas da casa. Em uma prateleira de ferro, no topo deste poste, fica um cubo de chumbo.

Essas duas obras não representam duas realidades opostas. São dois momentos da mesma realidade.

E não posso ocultar a emoção que me levou a imaginar, na minha própria língua, as obras naquela cidade, naquele país e, como um europeu bem ciente da natureza das novas perspectivas em vista, que inevitavelmente fico condicionado por isso, para o bem ou para o mal. 


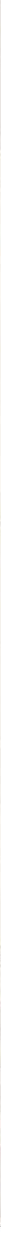




\section{Alberto Giacometti I99 I}

Publicado originalmente em Alberto Giacometti, Paris: ARC - Musée d'Art Moderne de la Ville de Paris, 1991, p. 439.

Eu nunca vi essas obras em seu estúdio na época, então devo imaginar tudo. Eu imaginei a escultura Homem andando em um quarto de hotel nos arredores de Paris.

Eu imagino a mesma escultura abandonada em uma fábrica de ferramentas, em Chicago.

Eu imagino a mesma escultura em uma necrópole europeia.

Eu imagino a mesma escultura em uma exposição coletiva com Picasso, Brancusi, De Chirico e Schwitters.

Esse homem da Antiguidade, Giacometti, o escultor, viu homens sem contornos e, com o gesto ascético de um monge pré-cristão, criou o tempo de um sopro de vento.

O homem como artista, que usava um sobretudo no inverno, tomou seu café no Les Deux Magots, comprou seus lápis, pegou o trem, experimentou livremente as aventuras da linguagem e, dia após dia, de acordo com seu coração, escolheu esses gestos permitindo que eles construíssem uma visão das esculturas sombrias aparentemente feitas de poeira, errática, em "movimento estático" perene, com dois pés grandes ancorados no chão.

Ele viveu sua era, ao lado da nossa, e com tenacidade nos deixou a centralidade do Homem. 


\section{Pulheim I99I}

Publicado originalmente em Kounellis, Pulheim: Synagoge Stommeln, 1991.

Stommeln, 21 de novembro de 1991

Estávamos caminhando alegremente, de forma segura e ordenada, ao longo da estrada rural arborizada, em direção a um certo e paradisíaco futuro.

Mas, de repente, a coincidência inesperada, diabólica e evasiva que nos leva para o sem forma e caótico. O que ainda era inaceitável há pouco tempo tornar-se-á uma realidade herdada.

Quem foi o traidor? O negociante de arte? Os generosos? Ou o rei cavalheiro? Quem foi o único a considerar a dor como uma impureza vencida? O proprietário ou o homem na rua? E pensar que tudo isso costumava ser uma defesa contra violações da confiança.

Agora sabemos que a fronteira entre o positivo e o negativo não possui contornos definitivos, como em tiras de quadrinhos. Estamos lentamente deslizando para a difícil tarefa daqueles que têm muito, ao contrário de quem não tem nada. Estar apaixonado hoje significa possuir os instrumentos para entender e a linguagem para recontar. Isso é tudo o que resta para um homem pensativo. Caso contrário, o castigo mais severo é deslizar para o meio do deserto, como quem cai nas entranhas do inferno. 


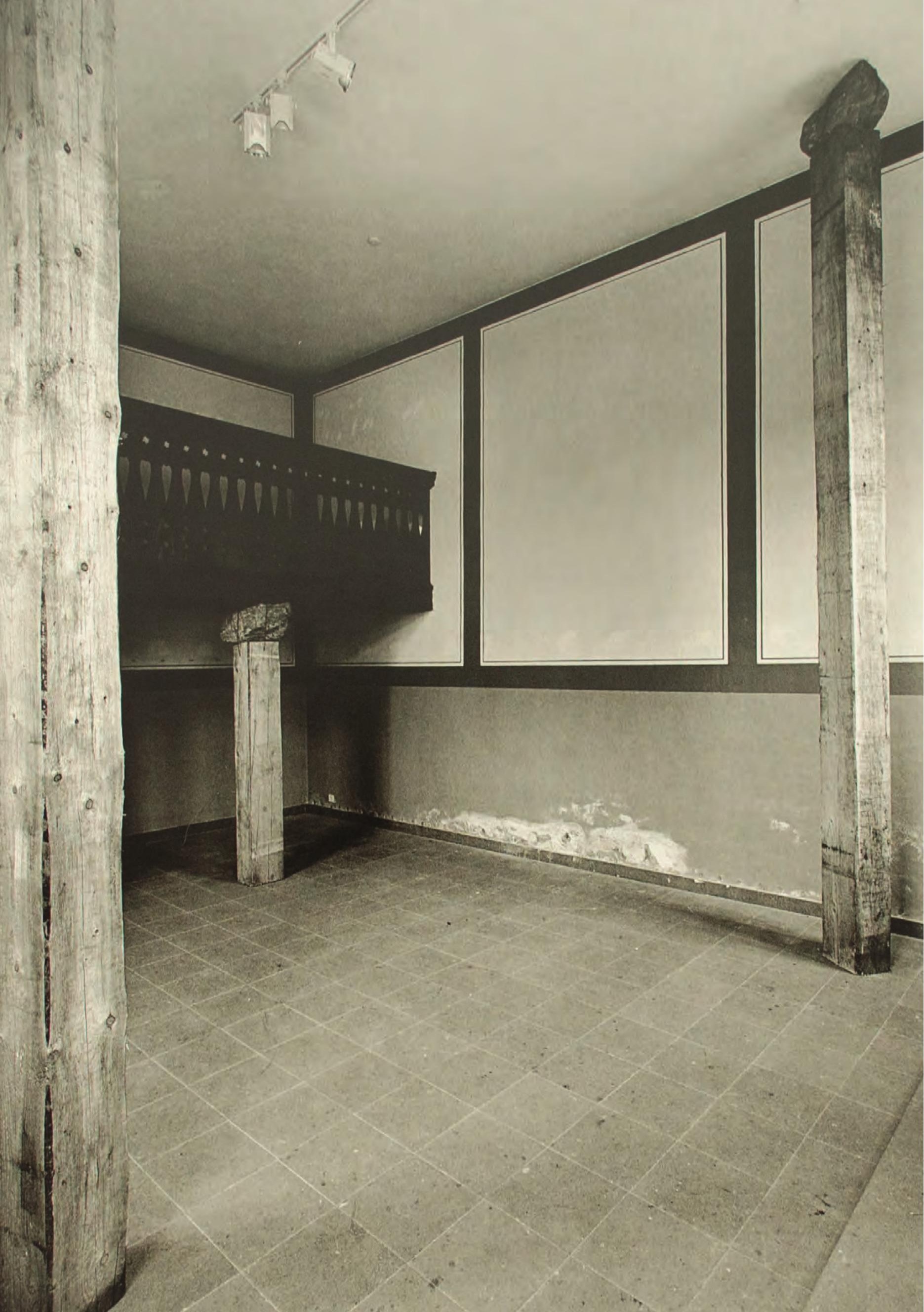




\section{La commedia dell'Arte 1992}

Publicado originalmente no convite da exposição Kounellis. La commedia dell'Arte, Nápoles: Galleria Lucio Amelio, 1992.

Nápoles, 20 de março de 1992

Talvez amanhã... não na sexta-feira... Talvez na próxima sexta-feira... talvez... talvez... talvez... talvez hoje... como sempre, mas definir qualquer coisa hoje é muito apressado. Em um mês talvez... talvez mais... talvez nunca... talvez nunca, ou então, hoje... sim, vou fazer isso hoje, como costumo estar pronto no início da manhã. E então, de alguma forma, eu esquecerei. Sabendo que amanhã será a ocasião que eu desperdicei ontem. 

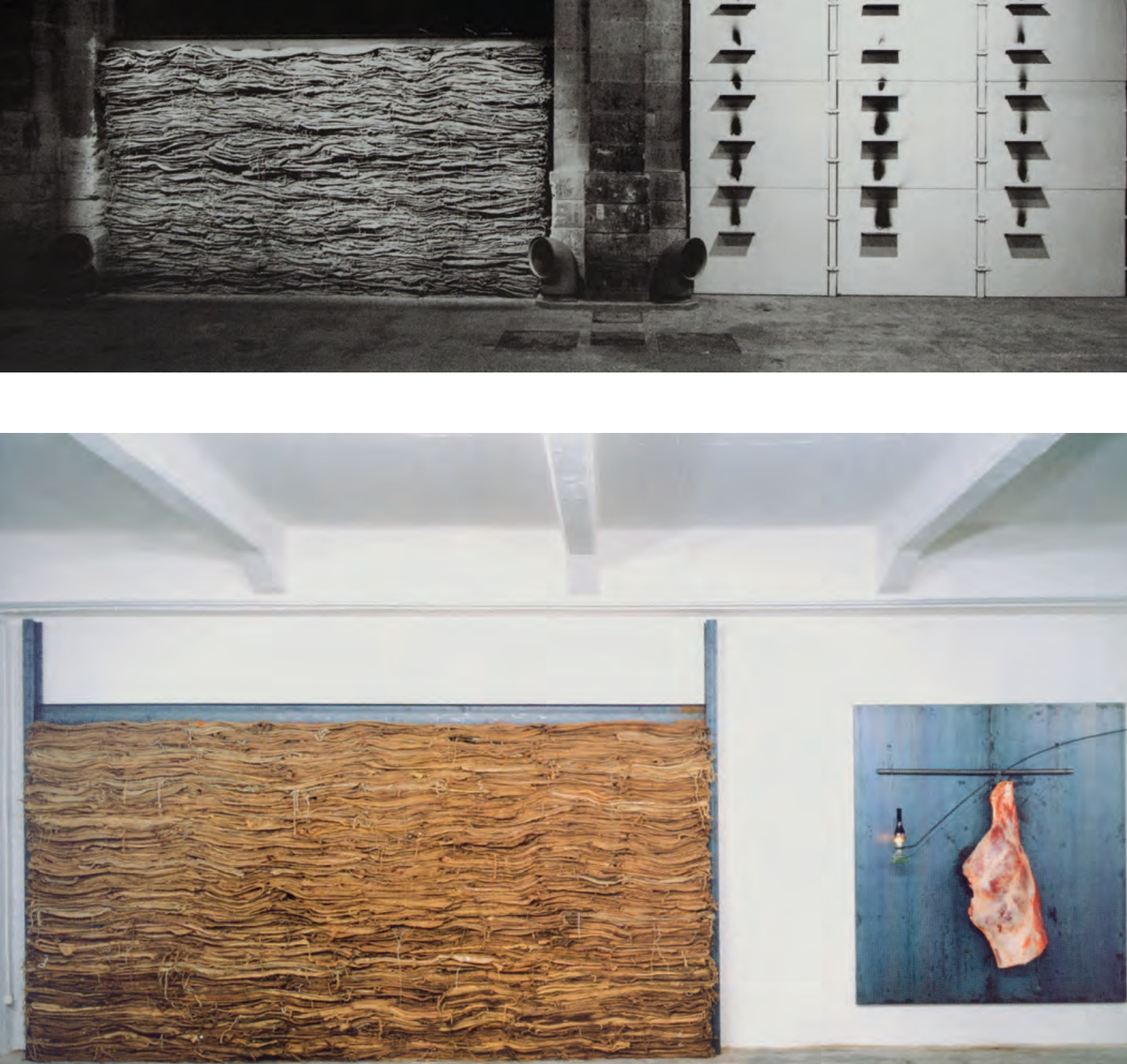


\section{Hydra 1992}

Publicado originalmente em Jannis Kounellis: works, writings 1958-2000, Barcelona: Ediciones Polígrafa, 2001, p. 257.

Agosto de 1992

Caminhando para o sul por dias e dias, num quente e opressivo dia, encontrei o Mestre B. Foi ele quem me ensinou a valorizar o espaço. Comecei a caminhar novamente, sudeste, pela trilha secreta do Mestre B, 30 milhas a leste, oculto na plantação de tabaco, estava o Mestre K, que me ensinaria a dirigir a emoção necessária para realmente representar a humanidade.

Após o encontro, que foi maravilhoso e útil, fui para o sul seguindo as indicações do Mestre K. Dessa vez, meu objetivo seria um encontro com o grande Mestre $X$ que me ensinaria a relação existente entre passado e presente, entre o passado que indica esse presente.

Em uma sociedade violenta e autoritária como a nossa, onde os valores se movem em frequências estridentes e onde a lógica simétrica entra em conflito com a lógica dominante dos interesses econômicos, sociais e do Estado, o que posso esperar dos encontros com aqueles homens de pensamentos sensíveis conhecidos como luzes orientadoras?

Talvez eu possa esperar encontrar a chave para a forma de governo.

Tal qual a última inovação, com a esperança de que o instinto, a parte mais pesada da vida de um artista, está bem desta vez, também. 


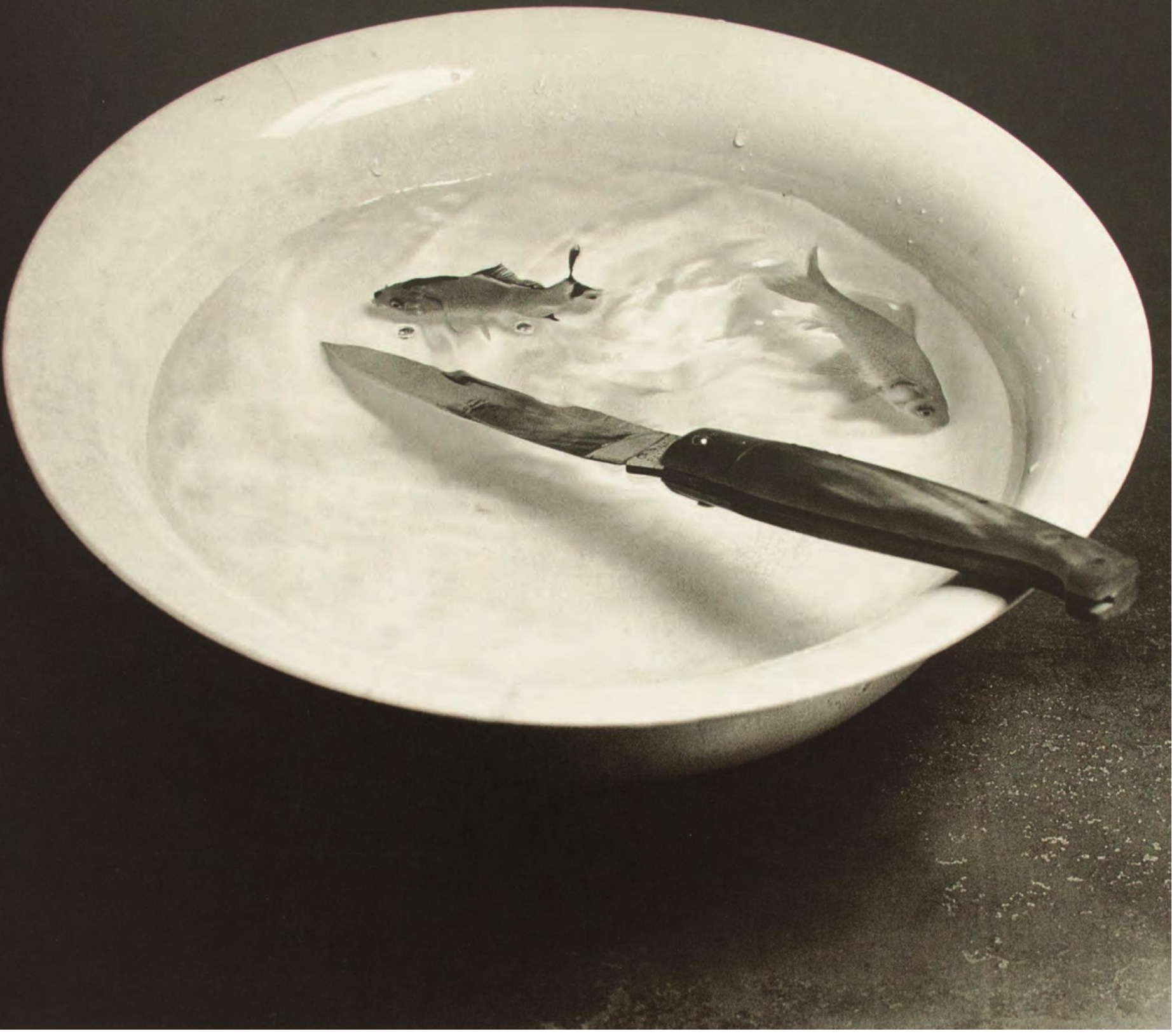




\section{Carta 1992}

Publicado originalmente na revista Tema Celeste, Siracusa, n 37-8, outono de 1992, p. 5-7.

A solidão louvada e representada pelos poetas românticos não tem nada a ver com a prisão de Gramsci. Somos, obviamente, parte dessa família ocidental que dispensa privilégios e bem-estar, mas, para que não nos esqueçamos, também somos a ovelha negra dessa família.

É evidente que, neste país, houve obstáculos e proibições que, pouco a pouco, deram origem ao isolamento, e que tal solidão pode aparecer como uma escolha de melancolia rara, mas precisamos deixar claro que a tarefa do pintor moderno, hoje como no passado, sempre foi e ainda é um esforço revolucionário. 

Senhoras e senhores, aqui está o meu balé estático I 992

Publicado originalmente em Terrae Motus alla Reggia di Caserta, Caserta: Reggia di Caserta, 1992, p. 82.

Nápoles, 2 de novembro de 1992

Senhoras e senhores, gostaria de apresentar meu balé estático a vocês. As figuras são uma coleção de imagens selecionadas. Um estágio vertical que consente a performance de uma peça de ação única. As dimensões das pinturas derivam das telas de Van Gogh. A figura de ferro corresponde aos óculos escuros do retrato de De Chirico de Apollinaire. Como um cego, escolhi as imagens de que eu gostava. Por um segundo, no palco, essas figuras falaram, cantaram e morreram.

Enquanto um terremoto e o naufrágio são imagens catastróficas, a Jangada de Géricault é positiva: é o primeiro passo que indica um caminho. Naquela manhã, há três dias, alguém gritou. Nem uma palavra foi ouvida, nem um choro. 


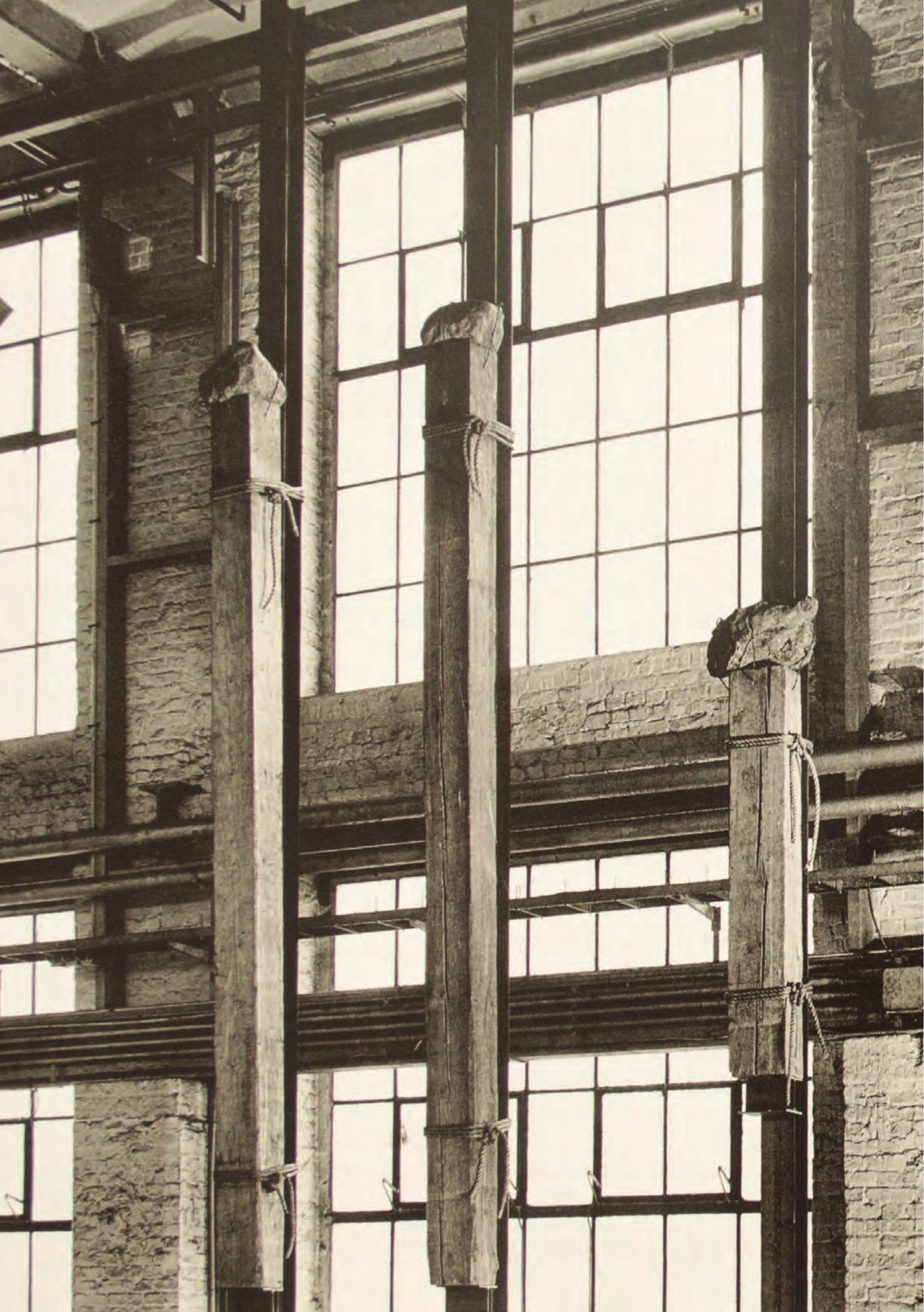




\section{Onde quer que eu tenha deixado minha capa de chuva I992}

Publicado originalmente em Configuraciones urbanas, Barcelona: Ediciones Polígrafa, 1992, p. 76

Roma, 9 de novembro de 1992

Onde quer que eu tenha deixado minha capa de chuva na noite passada, é onde eu também deixei minhas chaves da casa e minha lembrança disso desaparece lentamente.

No entanto, lembro-me claramente de que exibi as pequenas balanças de café em um barco de fundo chato ancorado, atrás do Stucky Mill em Veneza, e também em Nápoles, Roma, Chicago, Nova York, Paris, Krefeld, Eindhoven, Madri, Amsterdã e Moscou. Elas eram relativamente pequenas, eu poderia pegá-las com uma mão e elas sempre foram exibidas em ambientes fechados.

Desta vez, o trabalho foi recriado de forma vertical novamente, vertical como no passado, mas tão alto como o mastro de 18 metros de um navio e em ferro com uma tonelada. E é deixado lá, ao ar livre, numa pequena praça em Barceloneta, cabeça de ponte do grupo de casas que corre do interior para o mar, atrás da loja de tabaco via Almirante Cervera, com seu café, fruto da imaginação, do épico de transporte marítimo, da vida social do porto, com sua dor e sensação de aventura instilada. 


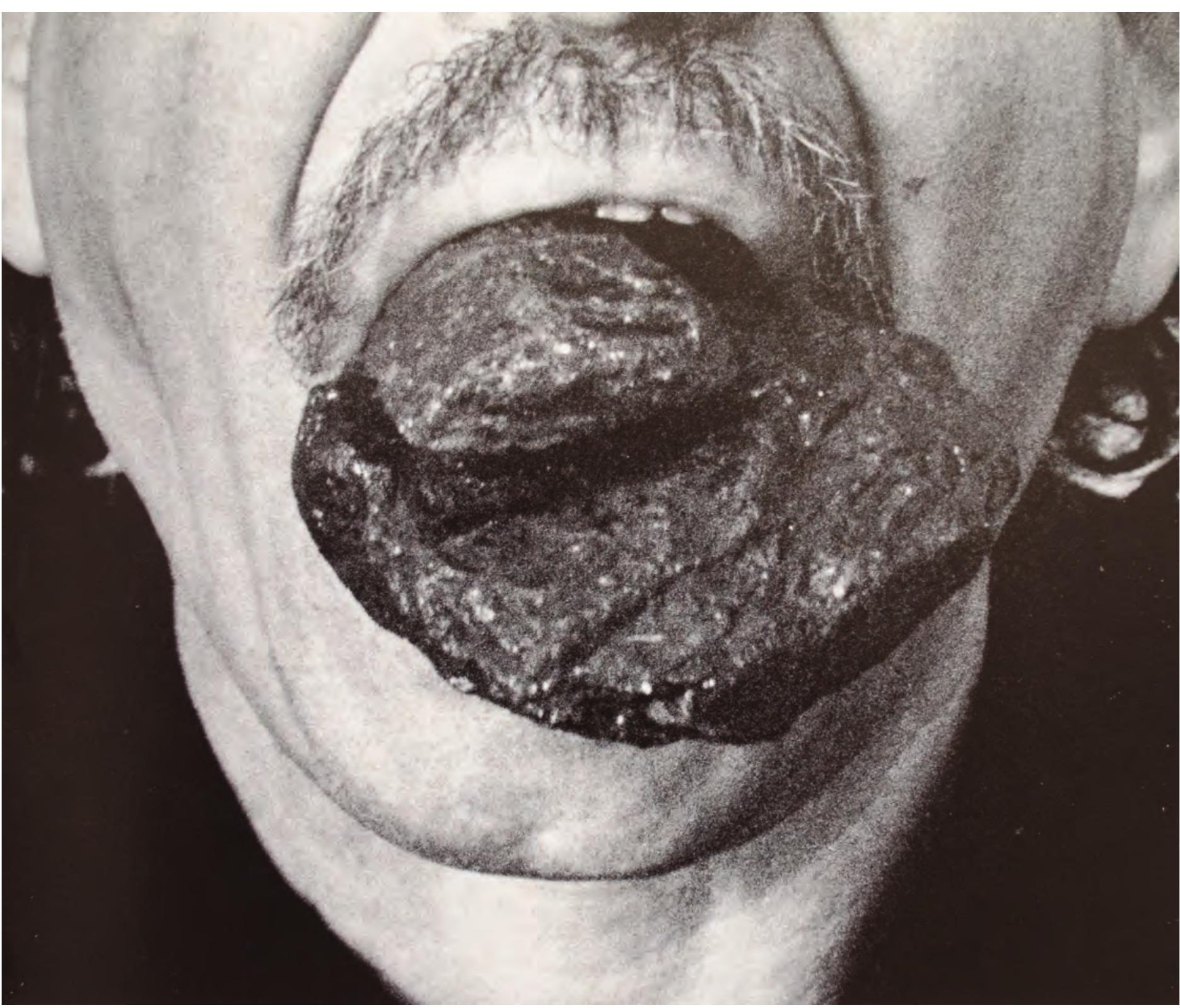




\section{Para Tempo di Migrare 1993}

Publicado originalmente como introdução do livro de Marco Gherardi, Tempo di Migrare, Milão: Rizzardi, 1993, p. 7.

\section{Café de l'Opera, Barcelona}

Esta figura feminina, gravada no espelho acima de mim, é iluminada e reflete as premissas e a clientela. Portanto, ela reflete, mas é uma imagem estável. Eu, como pintor, me atraio pela imagem gravada; ao mesmo tempo, vejo-me refletido e compreendo o motivo pelo qual aquele pintor escolheu há muito tempo o meio do espelho para gravar sua figura.

Minha imagem, como escrevo, não tem relação com a arquitetura, mas ao mesmo tempo tem relação com a realidade. Ela a ordena e a molda. No entanto, o espaço em que essa operação ocorre não é determinado em relação ao tamanho de um ser humano, mas é a essência codificada de sua voz.

Aqueles que pintam e aqueles que escrevem podem compartilhar uma visão; mas, para pôr em prática, cada um tem e usa um meio diferente. O escritor, como sua herança, tem a voz que reside em seu corpo e o pintor, a visão do sol que, do amanhecer ao pôr do sol, banha figuras, ilumina detalhes, cria sombras e divide o mundo em luz e escuridão. 

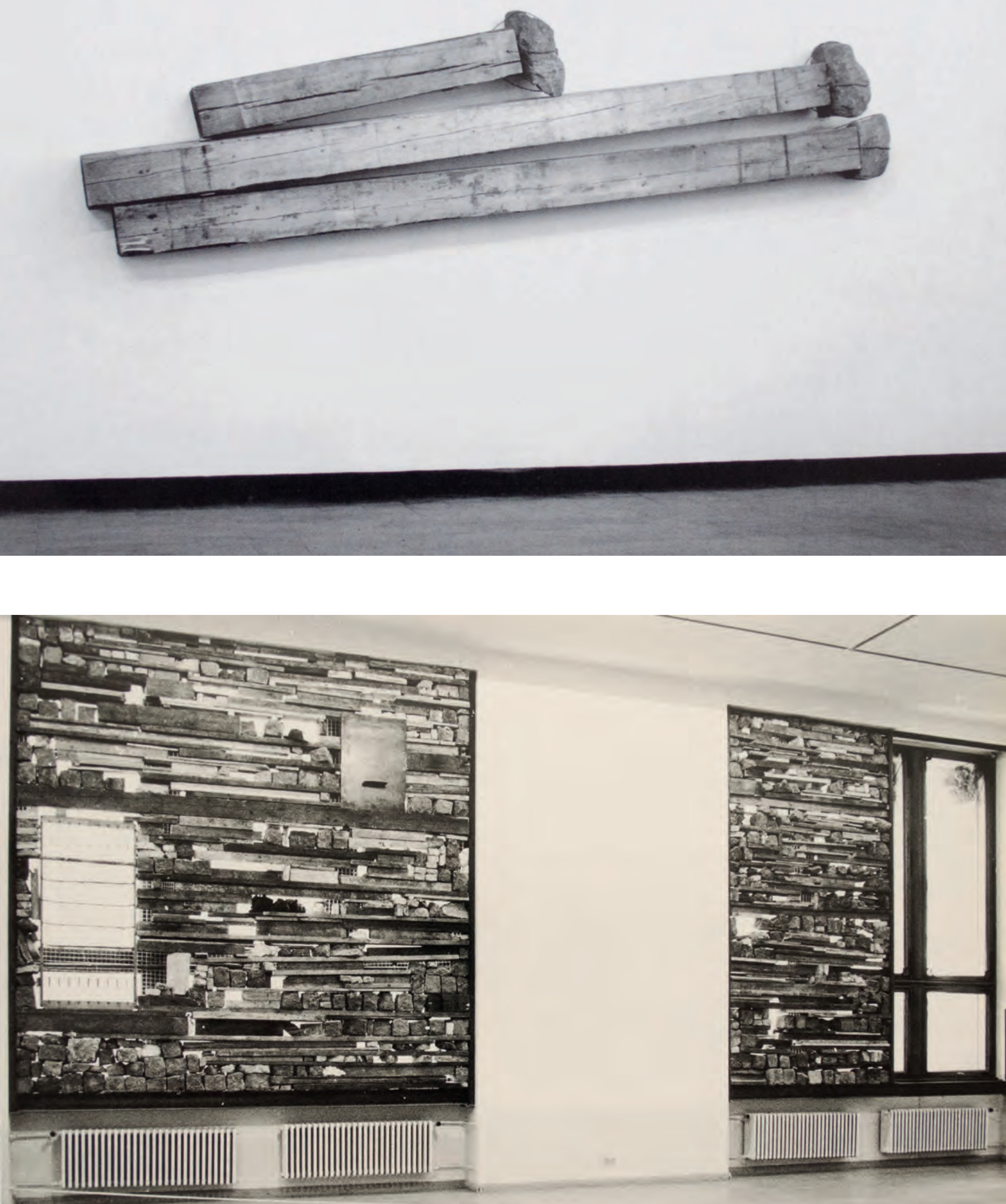


\section{Fumaça de pedra I 993}

Publicado originalmente em Kounellis Fumo di Pietra, Chatellerault: Galerie Lelong, 1993.

Nova York, 3 de novembro de 1993

Havia um pouco de fumaça nas janelas de uma casa de campo rústica para começar, e além delas podiam-se distinguir a paisagem e as casas na pequena aldeia. Então eu pensei que usaria meus dedos para apagar a fumaça que quase cobriu o vidro e desenhar rostos rapidamente, assim, desse jeito. Pelo mesmo procedimento, isto é, com meus dedos e tinta líquida, desenhei alguns rostos fantasmáticos na pedra, lembranças do tempo da janela esfumaçada no país. 


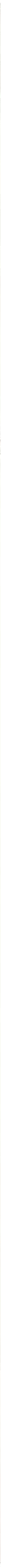




\section{Jogo selvagem 1994}

Publicado originalmente em L'Echoppe, Paris, 1994, p. 39.

26 de março de 1994

Atraído desde o tempo em que consigo me lembrar pela vida boêmia de artista, minha situação me permitiu, até agora, viver. Decepcionado pela atitude dos meios de comunicação de massa que deliberadamente retrataram o artista como uma cópia em série do financiador de Wall Street, fiz todo o possível na forma de falar e escrever para impedir esse projeto perverso, e talvez não tenha sido suficiente. "Talvez eu tenha sido muito indulgente." Espero que isso não seja interpretado como uma fraqueza ou um compromisso involuntário. De qualquer forma, todas as coisas contadas, considero a situação mais positiva do que parece. Eu prometo ser severo, continuar no caminho da oposição e extrair esse sopro de poética visível, mesmo que tenha que arrastá-lo pelas raízes. Eu prometo ser menos pluralista, reconhecer a única saída na verticalidade, não importa onde ela me conduza. Eu prometo pagar a minha dívida sempre em primeira pessoa.

153 Detalhe de Sem título, 


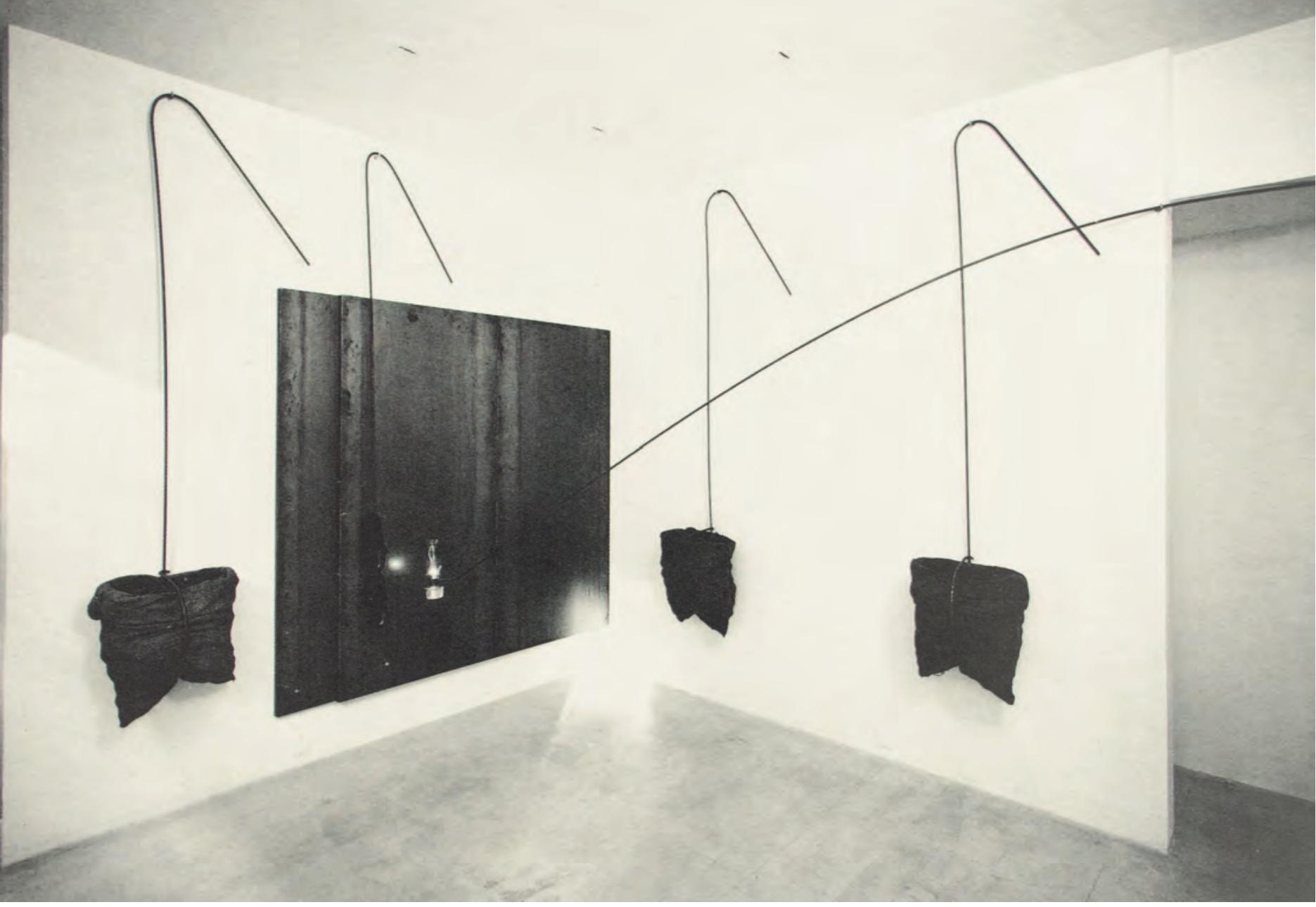




\section{Alto e baixo I994}

Publicado orginalmente em Affinità: cinque artisti a San Gimignano, San Gimignano: Studio per Edizioni Scelte, 1994, p. 6.

Alto e baixo, acredito que possua a altura necessária. A igreja de San Jacopo é alta, ou é baixa. O trabalho é tão alto quanto a igreja. Por isso, este trabalho se assemelha a uma torre sineira com a única diferença que possui um sino assombrado que nunca se move, e podemos ver que ele nunca se move. Naturalmente, é preciso ver para acreditar. Gostaria que o ferro com o qual ele foi projetado pudesse ser visto à tarde, porque naquela hora do dia a silhueta está escrita entre a pequena parede ao fundo e o céu, e com seu pequeno teto de ferro lembra as crucificações no campo, feitas de ferro, bem como as cruzes nas extremidades da torre ou as grades de ferro das casas abandonadas. O que é importante para mim é que ela não deve ser considerada uma escultura, mas uma caligrafia em uma parede marcada pela passagem do tempo. 

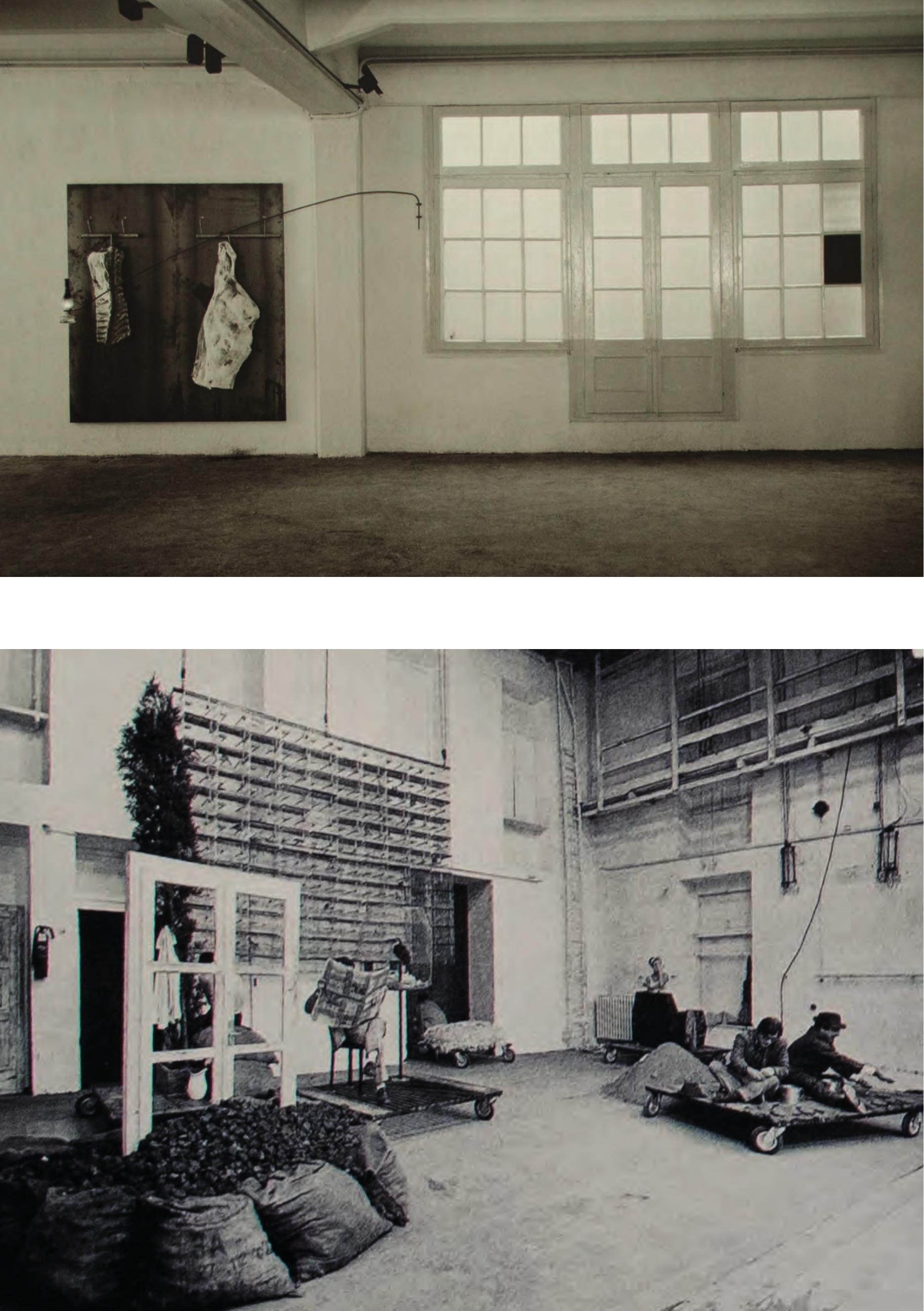


\section{Nós somos a minoria ou a maioria? 1995}

Publicado originalmente como introdução do livro de Vassili Vassilikos e Thanassis

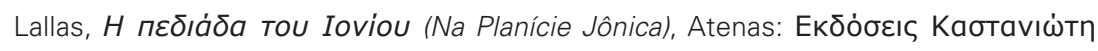
(Kastaniotis Publications), 1995.

Düsseldorf, fevereiro de 1995

Bem, somos uma minoria ou uma maioria? Somos a maioria das populações mortas, então somos artistas.

A partir dessa afirmação amarga, a visão assume uma realidade fantasmagórica. Conversamos e nos contamos sobre nós mesmos; pedimos dinheiro e, consequentemente, o dinheiro é distribuído, mas a nossa verdadeira realidade ocorre em um terreno diferente, incontaminado e virgem.

Somos a maioria desse oásis; nós amamos a humanidade, esperamos a fraternidade, buscamos uma alternativa.

Devemos vencer, ou, desta vez, também estamos condenados a perder; em comparação com os jovens recém-nascidos e com os idosos recémfalecidos, já somos os vencedores.

É uma boa ideia publicar ideias, observações espirituosas e imagens reunidas aqui e ali, com Thanassis Lallas e Vassili Vassilikos.

Embora nunca tenham sido exploradas, elas trazem novas perspectivas e saídas para a arte de um ambiente histórico e político muito diferente do que o de hoje.

As perguntas feitas por Vassilikos são uma mistura da curiosidade do estudioso literário em relação à arte e as ideias de política derivadas da experiência em primeira mão, apontam o caminho para as respostas banhadas no preto da arte e o azul (embora ideal quando se refere à pólis) das aberturas críticas. 


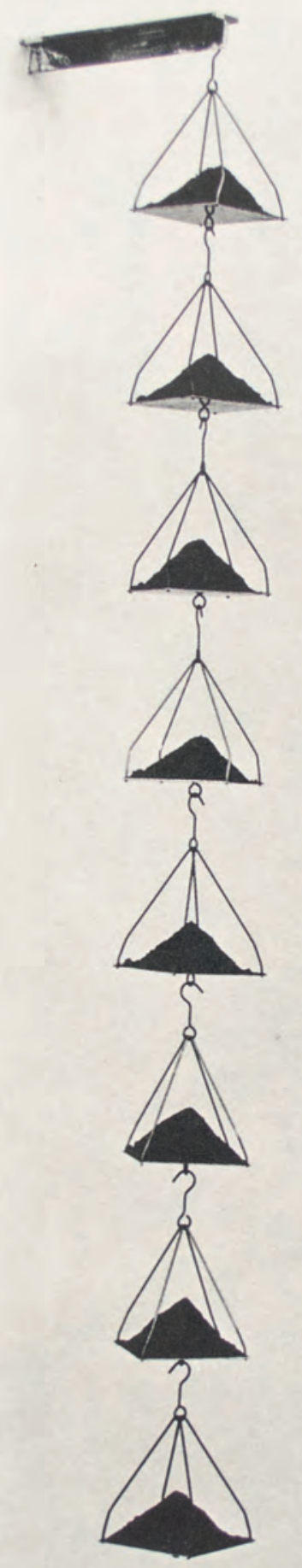

잉 


\section{Para Heiner Müller 1996}

Texto para a Fundação Heiner Müller, publicado originalmente em Echoes in the darkness, Londres: Trolley, 2001, p. 89-94.

Ao ver Heiner Müller falar sobre teatro em um palco ainda intacto por seu comando visionário, antes mesmo de os textos escritos terem sido incorporados nos gestos dos atores e suas respirações se tornarem história narrada, faz com que o palco de madeira vazio pareça um navio temporariamente sem um destino.

O início de seu trabalho no palco coincidiu precisamente com o desenvolvimento problemático desse espaço que se tornaria espaço, tempo, gestos, respiração e vozes. O próximo passo foi estruturado de forma a resistir a qualquer choque possível com uma audiência tão familiar para ele, e sua história como alemão foi o centro do seu teatro.

Propondo um jogo aberto estabeleceu um compromisso com a ilha dos mortos e sobreviventes. Os mortos nunca foram esquecidos naquele cruzamento no palco e parecia que o futuro, tão extremo quanto poderia ser, os incluiria.

A vontade de lembrar soou como um comando naquela cavidade cênica, como se o perigo de esquecer estivesse escondido nas asas. O temor natural era que as personagens, escritas com raiva, poderiam perder suas lembranças, seja pela fadiga ou pelo peso que as sobrecarregava, e, ao esquecer tudo e procurar uma paisagem idílica em que pudessem se perder, elas abandonariam a busca exaustiva de um futuro justo.

Então foi Müller o artista, e por isso frágil, tentando de todos os meios instilar o corpo do ator com uma frase-chave e um gestual (aparentemente muito exato para mim) de um soldado vencedor.

Não havia um enredo psicológico importante nos diálogos, mas sempre havia dois ou três personagens que pareciam arduamente esculpidos em ferro; tensos, seus gestos são eloquentes, eles pareciam iluminados pela lanterna de um soldado que destacava suas estruturas ósseas, como na pintura de Daumier.

157 Sem título, 1990. Estrutura de ferro e vidro contendo café em grãos, chapas de ferro, sacos de juta com carvão, hastes de metal e lamparina. Exposição em Berlim, 1990. Foto: Claudio Abate. Naquele "ginásio, navio de madeira, palco," o que era anguloso e grotesco adquiriu carne e alma, e enquanto alguma certeza fora dos muros do teatro naufragava e causava feridas e dores, o grande capitão Müller perseguiu sua luta. Na medida em que não estava claro se a tragédia acontecendo fora do Deutsche Theater tinha sido provocada pela encenação da peça ou se as ações no palco tinham sido condicionadas e 


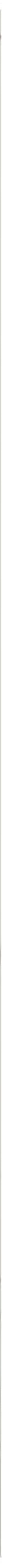


determinadas pelo que estava acontecendo lá fora.

Esta era a odisseia necessária para construir uma personagem previamente escrita dentro do corpo de um ator, que deve viver momentos de grande mudança, transmitir as palavras com a boca e, com seu corpo, os gestos para delinear as condições de um drama cujo epicentro é a base de uma cultura. Esse é o ponto em que o aviso para não esquecer torna-se uma realidade apocalíptica.

No projeto épico de Müller, os antigos não deveriam morrer, pois sua morte teria causado pânico, incerteza, perda de direção e qualquer inovação teria arriscado a ser desenvolvida em uma lama sem forma, em uma paisagem infernal que não oferecia nada além do estado trágico de uma superfície lacerada e instável.

O drama assim salvo e defendido foi mantido no palco com todos os meios possíveis, às vezes violentos, às vezes ternos, para evitar se afundar no esquecimento.

A política não era apenas uma escolha obediente para ele, mas acompanhou sua vida de teatro, poesia e dramaturgia, como a pintura A morte de Marat foi para David.

Este foi, finalmente, Germany, Year Zero, um visível não-futuro futuro, os motivos figurativos de uma "guerra de pós-guerra" ainda perdurada nos seus materiais originais. A luz sem alterações ao longo das décadas e até mesmo a poeira na janela tem um odor inesquecível para aqueles que sobreviveram.

A colaboração de Müller na trilogia com o Mauser Theater amadureceu durante esse panorama histórico, na paisagem urbana da Berlim Ocidental e da Berlim Oriental.

Começamos cortando um buraco de três metros de largura no palco. Um cilindro de ferro com um diâmetro de 80 centímetros emergiu do buraco com quatro metros de altura a partir do nível do palco.

A cavidade desse eixo vertical foi preenchida em suas extremidades com sangue. A uma altura aproximada de dois metros do perímetro externo

158 Vista da exposição fannis Kounellis - obras, 1958-2005, Faculdade de Arte de Edimburgo, Edimburgo, 2005-2006. Foto: Manolis Baboussis

159 Sem título, 2004.

Motores a diesel, grades de metal e biombos. Obra realizada em parceria com Magdalena Jetelová para a exposição O buraco na rede Magdalena fetelová e fannis Kounelis: bomenagem a Heiner Müller, Opera Paese, Roma, 2004. Foto: Claudio Abate. da cavidade, os trilhos do trem marcavam outro círculo e quatro vagões de trem do tipo utilizados para transportar carvão dos poços da mina percorriam esse trajeto: uma viagem obsessiva em torno de um centro indicado pela coluna de cheia de sangue. A terceira fase ocorreu no espaço além dos trilhos do trem circular. A peça começou com velhos armários de guerra saindo do buraco que contém o cilindro de ferro, e os armários foram colocados ao redor dele como um anfiteatro, desde a borda do buraco no palco até o ponto de partida dos trilhos.

Esse foi o espaço destinado à cena de abertura no Mauser. Müller era um extraordinário conhecedor do "teatro da Alemanha," de cujo gigantesco e imobilizado corpus extraía grandes e pequenos pedaços que ele trouxe para o palco para preencher vazios ou então para aplicar pesos onde 

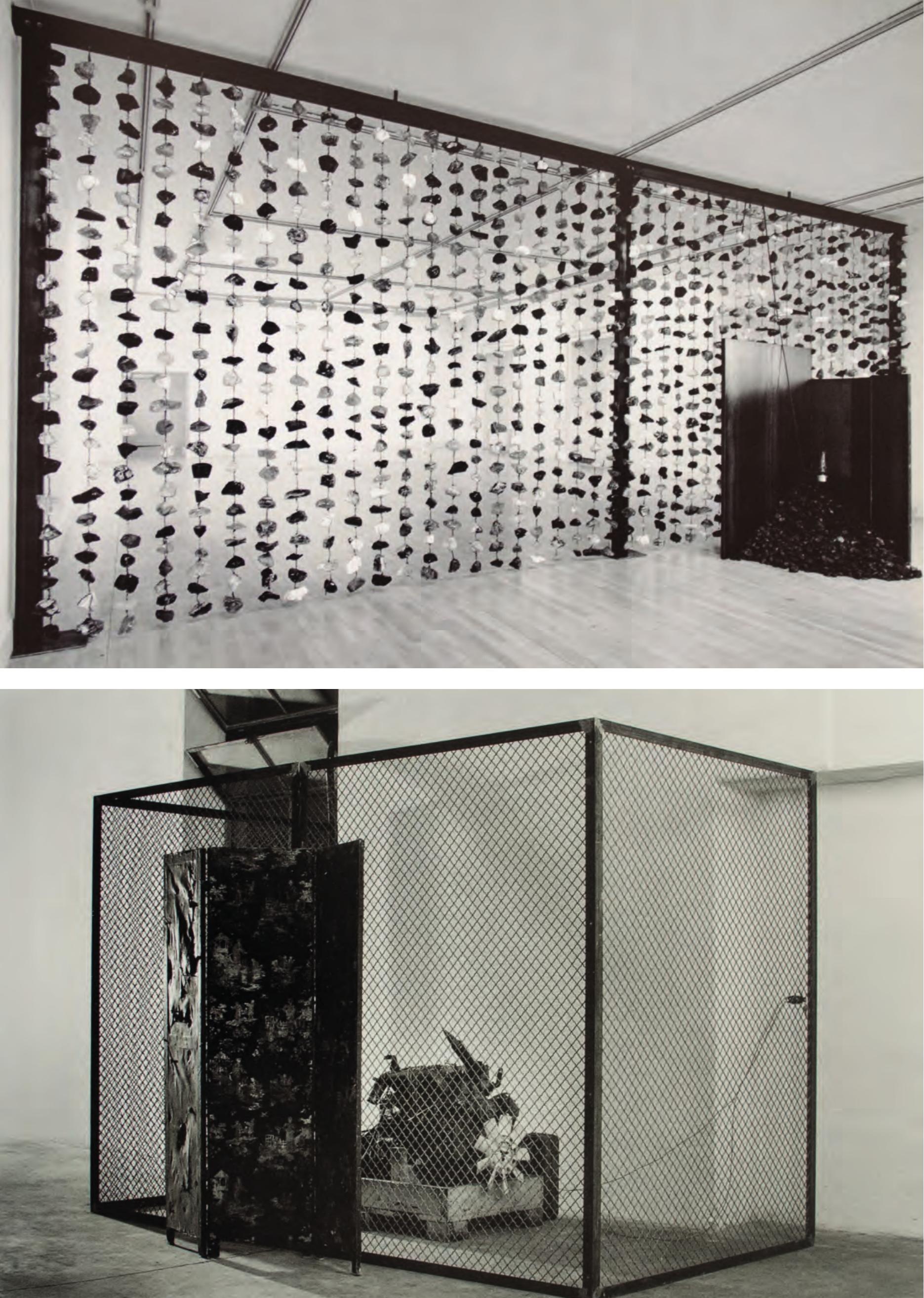
necessário, iluminado por uma luz que ele tinha visto anos antes, quando o drama era um fenômeno diário.

Os caprichos da crueldade que ele usava livremente e sem peso, como se estivesse decorando um apartamento no centro da cidade, como um jogo levado a cabo por alguém que tivesse experimentado esses jogos e agora é dominado e manifestamente marcado por seus traços.

O teatro era uma maravilha sombria, sanguinária e assassina, onde a performance ocorreu em uma mesa de cozinha, com antigos soldados de chumbo, modelos de caminhões em ferro fundido, trens em miniatura, figuras de papelão, cobertores militares e velhas placas de alumínio. Tudo era grotescamente para a música, interpretado por uma banda da aldeia. Müller estava recontando a realidade enquanto estava sentado em uma cadeira atrás de uma caixa de papelão em um palco de teatro iluminado sem efeitos, com atores habitualmente vestidos à sua frente, tentando com todos os meios possíveis criar tensão, moldar um vórtice, evocar centralidade, como se, milagrosamente, recuperando mestres dramaturgos (Brecht, por exemplo) ao longo de uma estrada rural, os defensores da tradição que indicavam o futuro de uma linguagem entre as linhas e impuseram suas indicações concretas sob pena de morte.

Depois de terem experimentado tantas tragédias, havia uma necessidade de se reunir em torno dos textos sobreviventes e recriar as condições de uma narrativa imaginária, para dar ordem aos fragmentos de uma identidade. Recentemente organizado e expresso, poderia então ser apresentado no palco, aquela mãe encantadora e severa, como a Olympia de Manet, cuja profundidade se pode expressar quaisquer que sejam as condições, mesmo as mais adversas, para uma audiência sentada e ouvindo à frente. Nessa arena de pós-guerra prolongada, uma zona fronteiriça de incerteza e silêncio, Müller, o dramaturgo, em essência morava no teatro, onde a única possibilidade de liberdade existia: as suas imagens no palco.

Durante esses anos no Deutsche Theater, em Berlim Oriental, que incluem a Hamlet Machine, a trilogia Mauser abrangeu um momento de emergência e mudança, e sentiu que o teatro era um território fundamental e privilegiado. Tudo parecia emanar desse centro incontestável. Foi a fonte de todas as tensões, e as análises podem ser classificadas quase visivelmente, como se fossem em uma biblioteca, para ser reutilizadas nos momentos importantes de encenação de uma das muitas peças a serem construídas e executadas.

A inovação desse cenário imaginativo foi que o texto foi recitado em um

160 Sem título (Cavalo), 1969. Doze cavalos vivos Galeria L'Attico, Roma. Foto: Claudio Abate. cenário sem intenções descritivas e que, em sua estranheza, serviu para enfatizar a essência das palavras e remover qualquer obrigação de ser decorativo. Isso permitiu que o buraco fosse cortado no palco do qual 


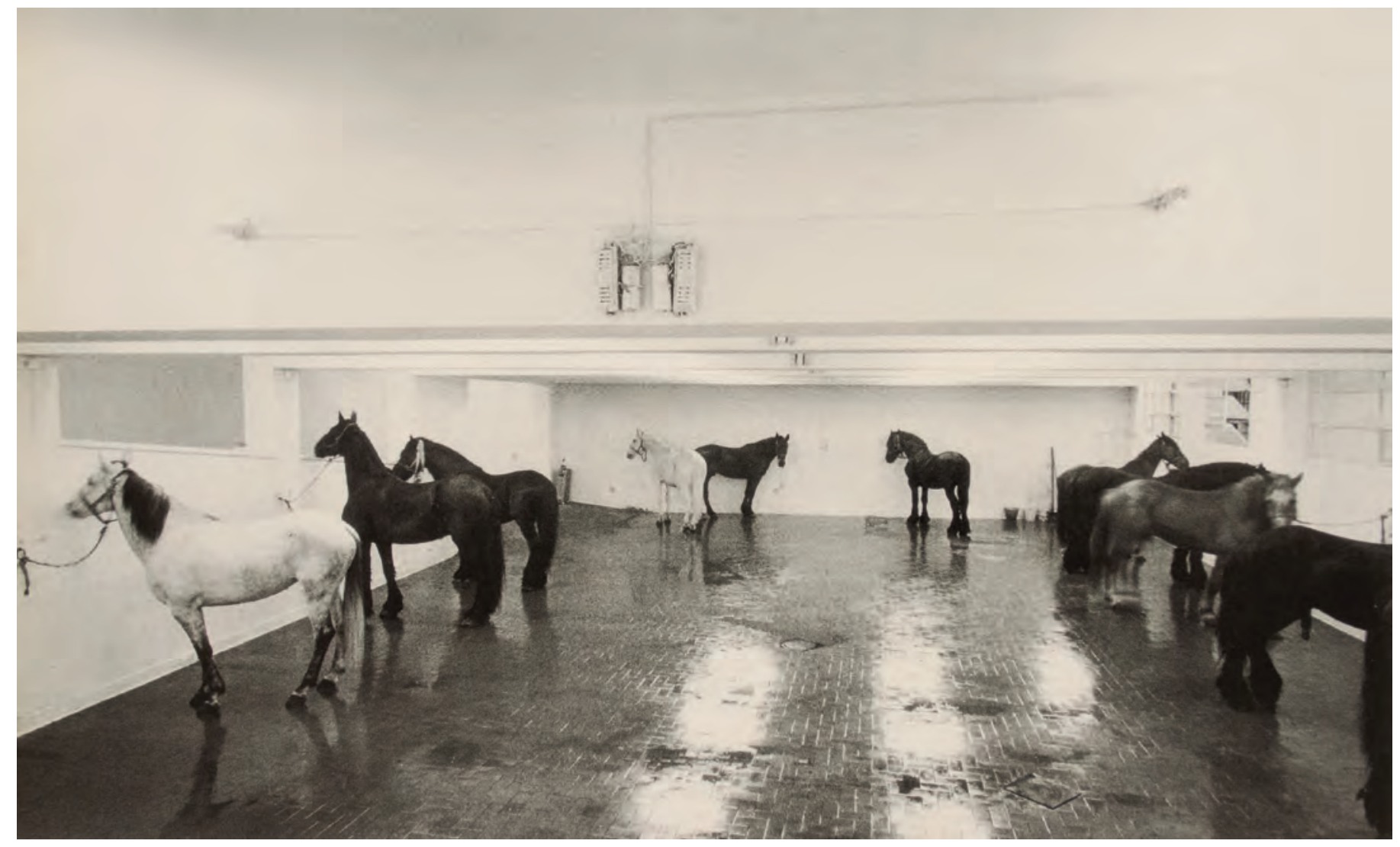


surgiu o cilindro de ferro preenchendo, como água em uma fonte, com sangue e com armários, as lembranças e a presença de uma era que realmente experimentamos. Essa ferida redonda tornou-se um poço lendário para nós, aqueles que caminhamos por aquele antigo palco de madeira. Müller não era um diretor. Ele organizou seus próprios textos. Ele não era um maneirista. Os textos orientadores eram evidentes e visíveis, observados de um ponto de vista único e banhados na realidade. Ele não era um perfeccionista, mas manteve sua emoção ancorada dentro, como qualquer pessoa faz ao construir uma pintura respeitável. O tempo de palco dele era o de um corredor de maratona, mais lento do que um velocista, mas incrivelmente consistente na busca de uma finalidade distante perdida no horizonte. Suponho que ele amava as pinturas por sua qualidade sintética, a facilidade com que se pode interpretá-las à primeira vista e porque sua construção é feita a partir de uma estratificação da memória misturada com outra que a cancela acrescenta outra memória recém-descoberta.

Guernica de Picasso pertence de alguma forma a essa visão de guerra de pós-guerra no teatro? A mão que carregava a lâmpada de óleo estava presente? O cavalo caiu em uma careta exasperada de dor presente na peça Mauser, ou as gordas figuras da classe média de Grosz empurrando e gritando, com seus chapéus de jogador, que povoaram suas pinturas? Eles estavam na peça Mauser? Os campos de trigo no campo ao Oriente, todos amarelos com pássaros cinzentos marcando a paisagem do verão, pinturas com visões retrógradas, soldados feridos, canhões, casas em chamas, socorristas... Sim! Eles foram fixados naquela cena da mesma maneira intensa que Guernica estava presente nas pinturas de Pollock, como o existencialismo exasperado de Beuys, a ideia de peso e as separações de corte entre uma coisa e outra, estavam presentes.

Ele cultivou sombras, dando uma qualidade até então desconhecida à sombra, conferindo futuro a ela em uma época em que cores planas eram predominantes em todos os lugares.

O amor de Müller por Faulkner foi indicativo, visto nessa perspectiva. Isso o levou a escolher uma certa América onde encontrou Faulkner, Pollock, Arshile Gorky, Duke Ellington e Billie Holiday.

Precisamos delinear confins e dar torres de observação nas colinas à hipotética pedra memorial onde os nomes de Paulo - Apóstolo de letras

161 Sem título, 1984. Trinta e cinco prateleiras de metal com fuligem. Foto: Claudio Abate. 162 Vista da exposição Kounellis. Galeria Lucio Amelio, Nápoles, 1969. Foto: Mimmo Jodice.

\section{-, Santo Agostinho, Giordano Bruno, Shakespeare, Marlowe, Diderot,} Goethe, Joyce, Brecht e Beckett seriam gravados. 


\section{Capodistria 1996}

Publicado originalmente em Jannis Kounellis. La Balera, Capodistria: Galleria Loza Koper, 1996.

Por trás de tudo, a pressão urgente do saber, para ter certeza de que a ferida existe; e que você pode mergulhar seu dedo nela.

Mas a vida com seu gozo alegre também existe.

Qual é o motivo dessa viagem. Fazê-lo agora é justificado pelo fato de que a realidade de hoje não pode ser repetida. A mensagem visível hoje só pode ser contada no futuro, mesmo amanhã, o que não é o mesmo. 


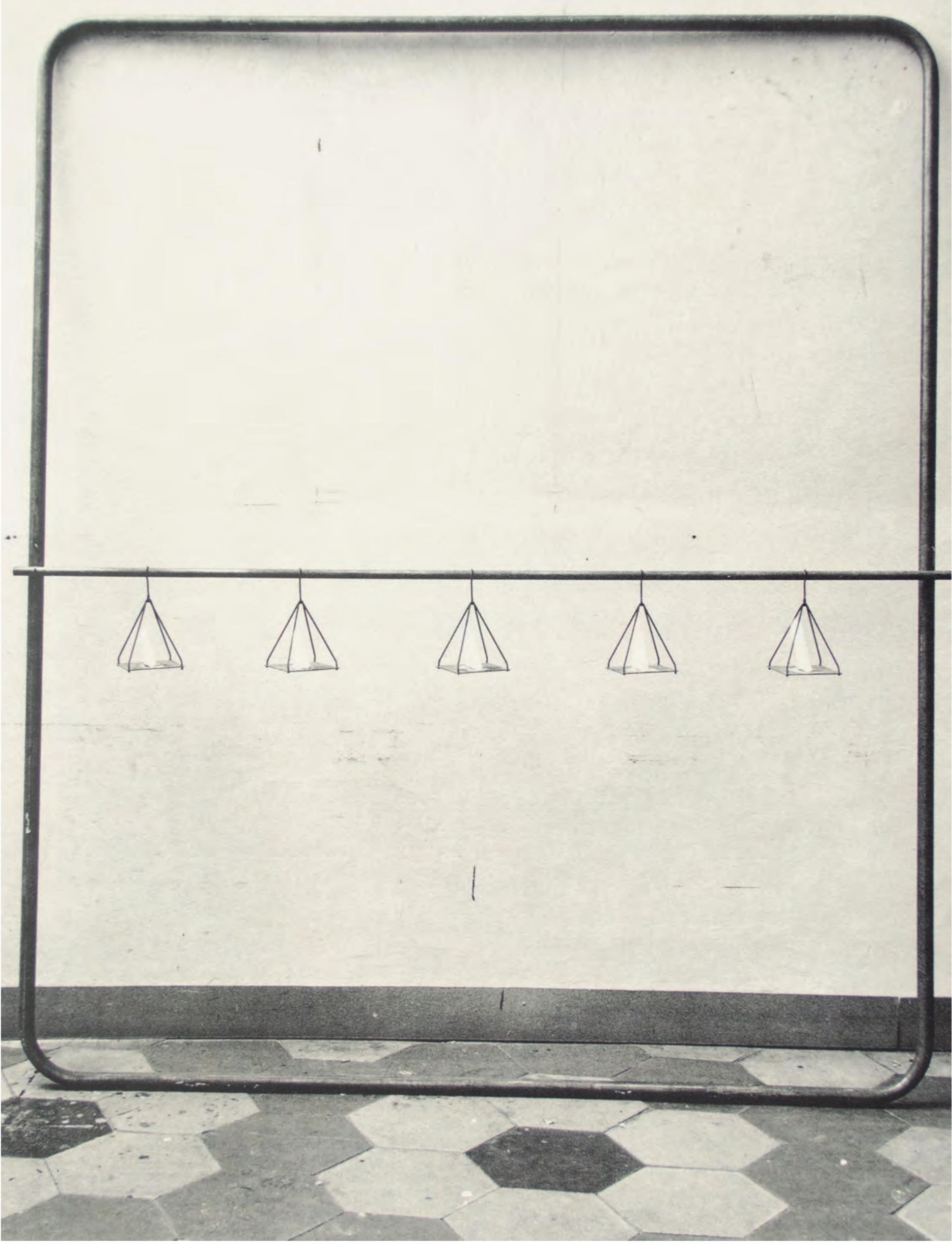




\section{Para Edvard Munch 1996}

Publicado originalmente em Munch en na Munch, Amsterdam: Stedelijk Museum; Oslo: Munch Musset, 1996.

Oslo, Ilha de Naoshina, 22 de março de 1996

Encontrei Munch através das pinturas de Boccioni, a "ponte principal", e aprendi a entender uma capacidade tocante para expressar a condição da humanidade em seus sombrios silêncios.

Suas pinturas são cativantes. Eles podem lançá-lo nos caminhos mais audaciosos com o risco de perder o caminho de volta, mesmo que se contraponham com a ideia de padrão e da harmonia de praças bonitas da cidade, de cemitérios secretos empoleirados em colinas, de calor feroz e de sombras negras que limpam o que quer que aconteça.

Munch, o pintor, possuía um conceito real de teatro. Ele pintou o drama da humanidade, em seus movimentos e em seus rostos, máscaras visionárias de uma história que reside no crepúsculo.

Ele era um marco fundamental e inevitável em viagens para o norte. Não se pode deixar de admirá-lo, e, depois de retornar, não se pode esquecê-lo.

Assim como os ciprestes de Van Gogh, O grito de Munch deixou suas marcas na expressão de uma dualidade que considerava celestial como bonito e infernal como feio. Isso nos permitiu uma visão em primeira mão de um inferno positivo e belo, e, ao mesmo tempo, nos carregava com a pura e abrangente, libertadora, tensão de agarrar um vínculo intelectual no centro de uma celebração sem fim e tornando-nos um cúmplice. 


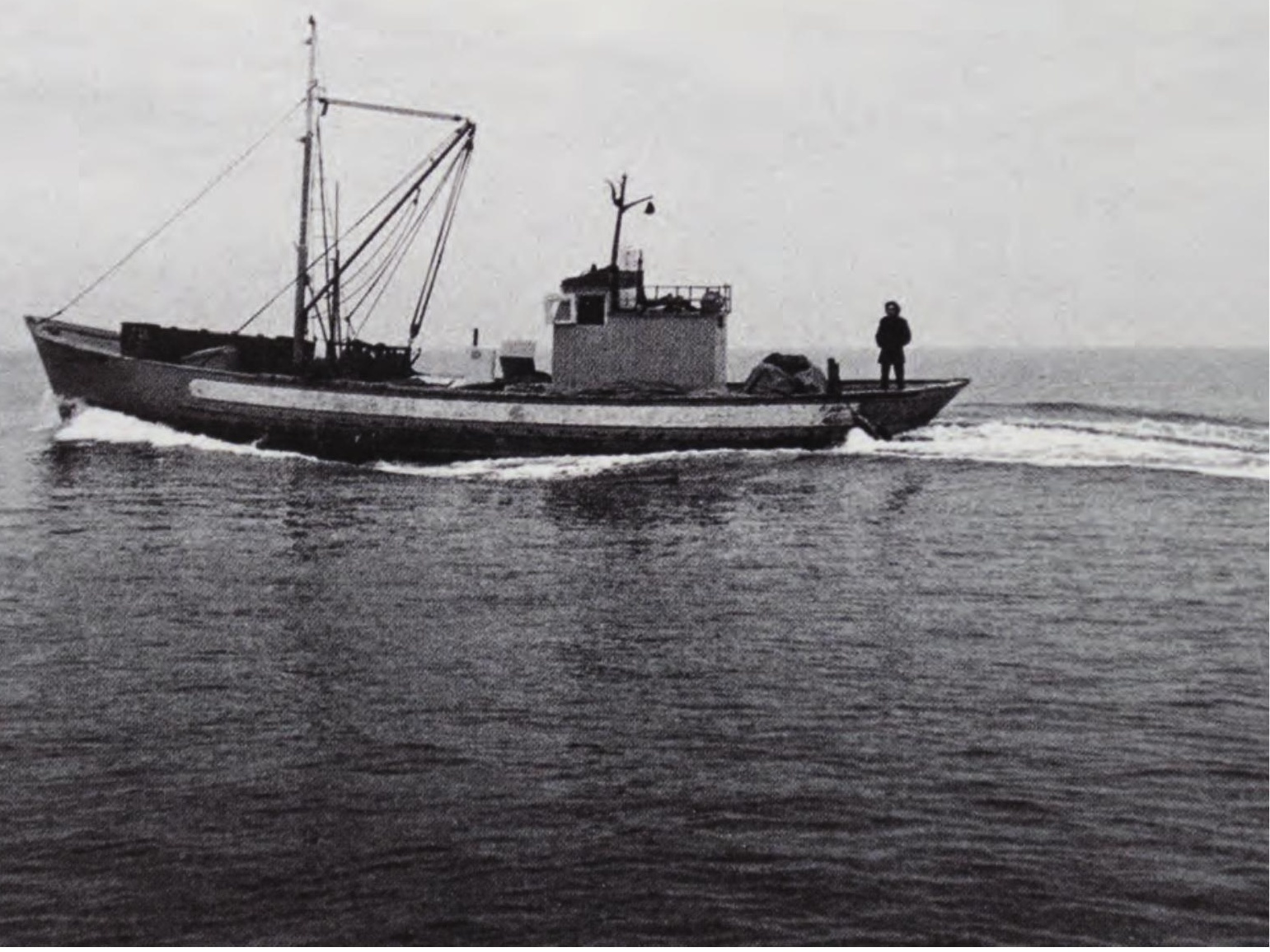




\section{As palavras que me explicam 1996}

Publicado originalmente no jornal L'Espresso, Roma, 1 de agosto de 1996, p. 102-103.

Artista ou pintor

Eu fui chamado de artista nos anos sessenta porque eles não sabiam como definir uma pilha de carvão. Mas eu sou pintor, e afirmo minha iniciação na pintura. Porque a pintura é a construção de imagens e não indica uma maneira ou, menos ainda, uma técnica. Cada pintor tem suas próprias visões e seus meios de construir imagens, e a linguagem que associa a palavra pintor à arte tradicional e a palavra artista ao papel de anarquista, modernista, experimental, é ridícula.

Jackson Pollock foi um pintor que reinventou epicamente o espaço americano. Os murales mexicanos estão pintados, todavia Duchamp também é pintor. O liberalismo concedeu à pintura uma liberdade chegando aos limites do imaginário e restaurou completamente o papel do intelectual para o artista.

Fogo

O fogo não é apenas calor, mas também uma fonte de luz. A lâmpada de óleo que iluminava a cena de Guernica, ou a vela que iluminava o rosto da mulher perto da mesa na pintura de La Tour, criava sombras, volumes marcados e, com alguns toques aqui e ali, determinava a imagem.

A primeira vez que usei um maçarico foi em 1967, para marcar o centro de uma escultura, uma margarida metálica, de modo a acentuá-la. Então, em 1969, na Galeria lolas em Paris, coloquei maçaricos ao longo da parede, em uma linha horizontal, ao nível dos olhos, para indicar o perímetro da galeria. O fogo, para mim, é equivalente ao papagaio em 1967. É vivo, gira-se agressivamente em direção ao exterior. Mas nenhum deles, nem o fogo nem o papagaio, teria sentido sem o suporte de ferro. Eles são vivos, reais, mas acima de tudo são signos de uma imagem construída a partir de relações. E, em meu entendimento de longo prazo, ambos são pinturas

165 Sem título, 1978. Modelo de barco, sacos de juta e tela pintada. $100 \times 80 \mathrm{~cm}$. Foto: Claudio para mim. Me perguntam se eu sou um pintor realista, e a resposta é não. O realismo representa enquanto eu apresento. 


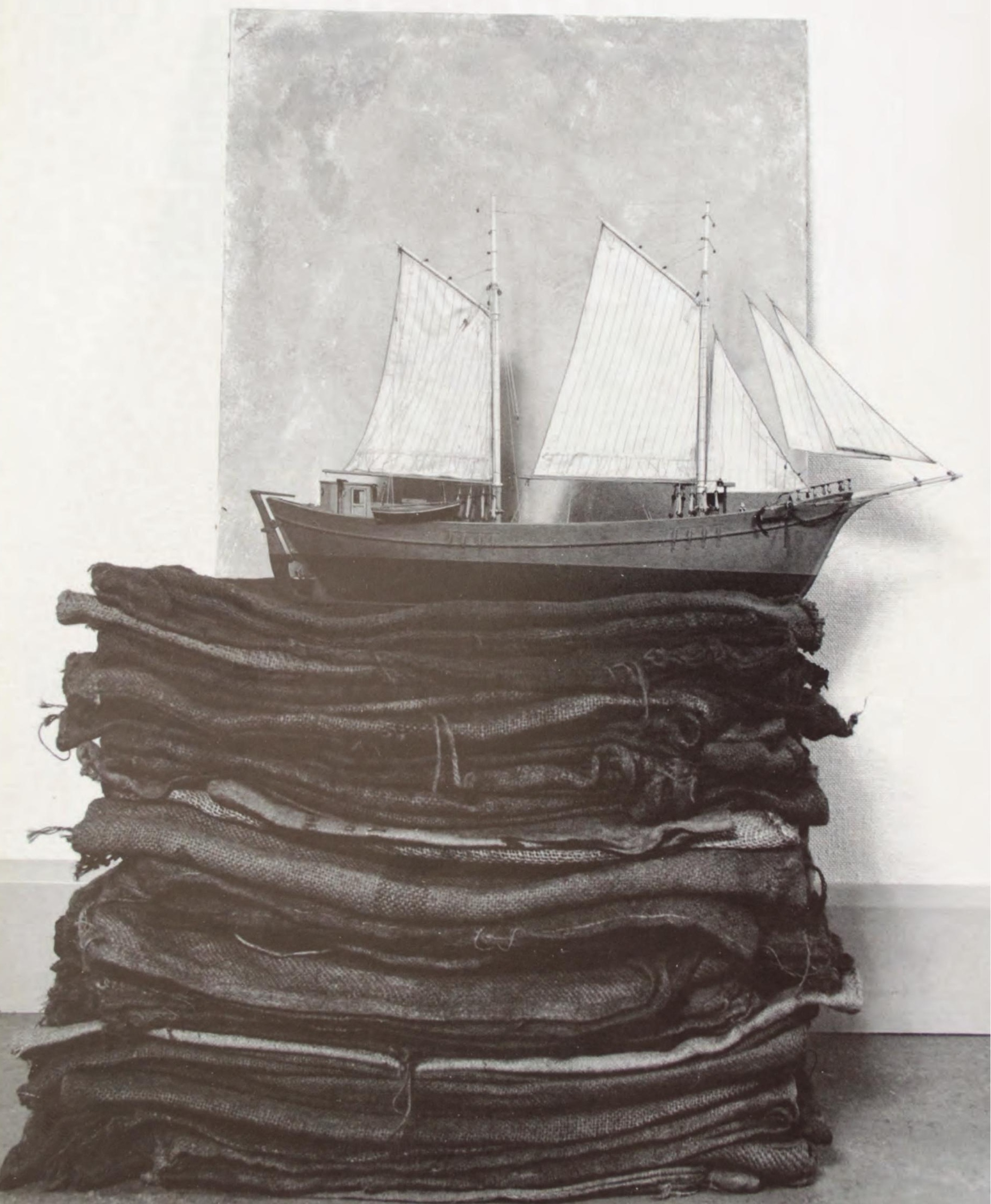


Parede

Eu construí muitas imagens com fogo e muitas com paredes. Paredes de pedra, madeira, troncos, livros, sacos. Uma parede coberta com folha de ouro. E minhas primeiras imagens com flechas e letras também eram paredes. Elas tinham as dimensões das paredes da minha casa e foram pintadas com tinta de parede. A tela encostada contra a parede, eu a removeria e colocaria outra. Tudo isso só para dizer que nunca pintei uma imagem sobre um cavalete. Em 1969, em San Benedetto del Tronto, emparedei uma porta com pedras simplesmente encaixadas. A cavidade da porta me permitiu construir essa imagem inteiramente de pedra. Não era uma oclusão, era uma imagem com as dimensões da porta. O meu problema não é o encerramento, mas sempre a revelação.

\section{Declaração}

Na minha individual em Berlim em 1990, quando o Muro caiu, reativei um velho carrinho cheio de sacos de carvão, fazendo-o ir de um lado para outro em trilhos que juntavam duas partes de um edifício abandonado. A exposição abriu no dia 13 de setembro e fechou no dia 2 de outubro, último dia da República Democrática Alemã. Isso é apenas para ressaltar o fato de que expor em uma galeria ou em um museu é planejado com uma visão direcionada e simbólica. No século XIX, não havia exposições individuais. Havia apenas exposições coletivas nas quais cada artista mostrava o seu melhor trabalho. Isso não Ihes deu uma chance de fazer uma declaração. Cada artista hoje pode afirmar algo com uma individual porque seu papel é mais forte. Ele tem sua própria identidade de pensamento e liberdade intelectual.

Teatro

A teatralidade é uma coisa e o teatro é outra. Toda a pintura italiana é teatral até certo ponto. Caravaggio, por exemplo, ou Tiepolo. Essa é uma espécie de teatralidade que busco no meu trabalho. Contudo, também trabalhei no teatro como pintor. Quero dizer, nunca trabalhei como ilustrador, mas trabalhei como cenógrafo, com Carlo Quartucci e

166 Sem título, 1969. Seis sacos de juta costurados e estrutura tubular. $190 \times 160 \mathrm{~cm}$. Foto: Claudio Abate. Heiner Müller, em espaços novos e clássicos, como o Teatro Gobetti e o Teatro Deutsche, ou na Ópera em Amsterdã e em Berlim, mas com liberdades desconhecidas para um cenógrafo. Trabalhei nesse teatro que buscava suas raízes clássicas e desejava deixar a ambiguidade da 


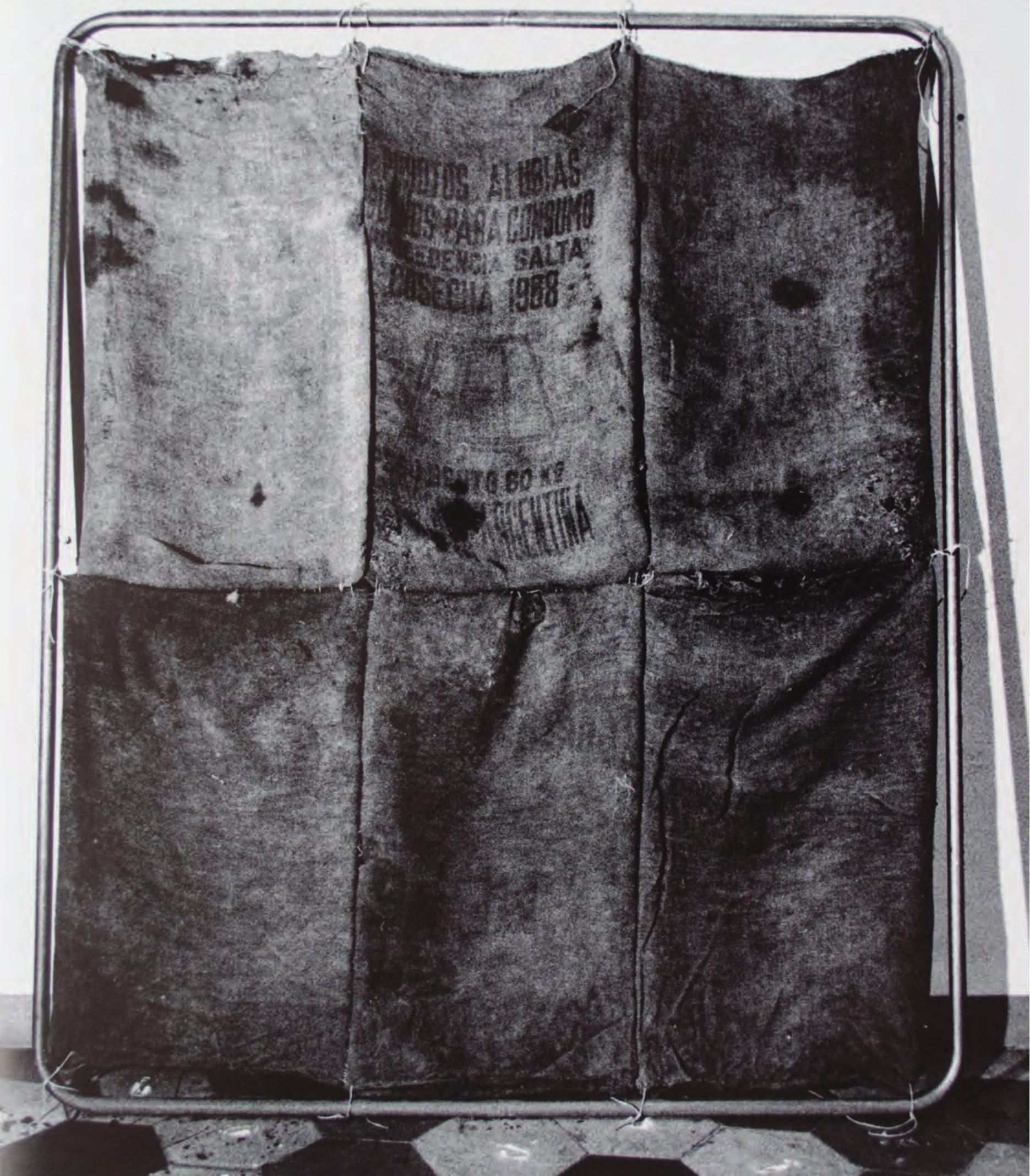


comédia burguesa do século XIX. Cenário naturalista ambientado num espaço descritivo que, com tons cinematográficos, sublinha os eventos narrativos: a chamada decoração. Tentamos reconstruir o teatro. Não me fale, porém, sobre limites de cruzamento. Eu não sei o que isso significa. Eu nunca ultrapassei os limites.

\section{Viagem}

Uma viagem significa "ir ao outro lado" para mim. Eu me atraio por ir ao outro lado, como qualquer outro artista, por razões culturais e por esse senso de aventura que sempre é instilado na arte. Porém, não é exato afirmar que uma busca é uma jornada para o desconhecido. Sempre se é atraído por algo conhecido, ainda que pequeno. Desejando ver uma pintura de Van Gogh, chega-se em Paris. Encontra-se Paris e, com Paris, a cultura francesa ...

Cada viagem tem uma natureza iniciática, é uma ideia ativa, amorosa e expansiva do conhecimento. Muitas vezes, as viagens estão implícitas em minhas obras, entretanto seria óbvio associá-las à minha individual no navio. A exposição em Chicago era muito mais parecida com uma jornada, na medida em que se expandia para fora, em direção a outros espaços periféricos, além das salas do museu.

\section{Guardião}

Eu sou um conservador. Um guardião. A realidade invisível é apócrifa e seu significado é conhecido pelo seu guarda. Portanto, o guardião preserva um acesso geral aos segredos místicos conservados.

A origem da composição é a custódia e, em termos de composição, conserva a ordem e une o presente e o passado. E o pintor moderno é um homem da antiguidade, como em qualquer outra época. 

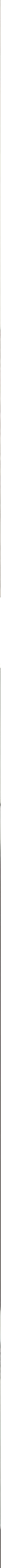


\section{Caro Ingrao 1996}

Publicado originalmente no jornal L'Unità 2, Roma, 17 de setembro de 1996, p. 1-2.

Caro Ingrao da Galeria de Arte Moderna de Roma

A Galeria de Arte Moderna, em seu potencial para exposições e coleções, não desempenha nem mesmo um quarto da atividade de um museu em qualquer cidade alemã. Certamente não é culpa do deputado, mas também é sua culpa, e dessa mentalidade que dificulta a condução de uma exposição e não aceita que as críticas, realizadas pelos críticos, sejam a única ferramenta aceitável que leva à maturidade. Perguntou-se ao chanceler Kohl o que poderia ser feito pela arte e ele respondeu: garanta a liberdade de exibição. Esperamos que nossos políticos entrem e visitem as exposições, mas como espectadores. O retorno a um realismo ou a um classicismo revisitado, por vontade do Estado, não é sequer pensável. Estou curioso para saber o que o deputado dirá sobre a Bienal da Moda em todos os museus da Toscana, imagino que nada, é claro que onde os meios econômicos existem, a harmonia está em casa e tudo fica bem. Os anos se passaram com lutas e esperanças, discussões para não acabar com o amor deste belo país. Parecia ultimamente que havia sido alcançado um equilíbrio e que uma verdadeira democracia estava à porta, mas aqui está o deputado, desta vez de esquerda, que corre para a delegacia para denunciar um artista que ousou ser livre e antidogmático. Caro poeta Ingrao, protesto e sinto como se alguém tivesse roubado meus sonhos, esperanças e futuro, e anseio pela cultura de esquerda. Quanto ao deputado, não se preocupe. Eu não torturo pássaros e não como crianças, meu papagaio de trinta anos atrás ainda vive comigo. 

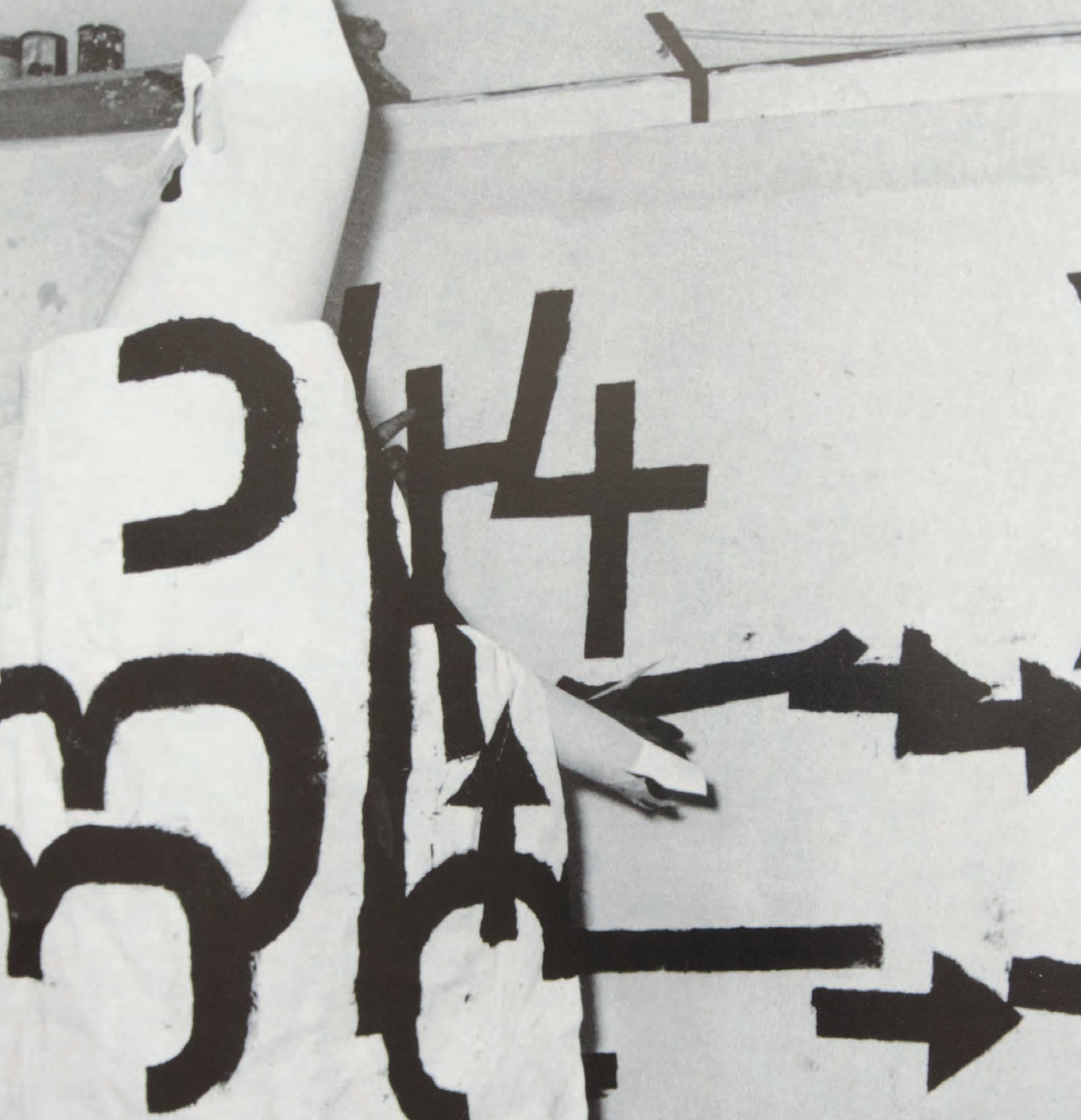

7
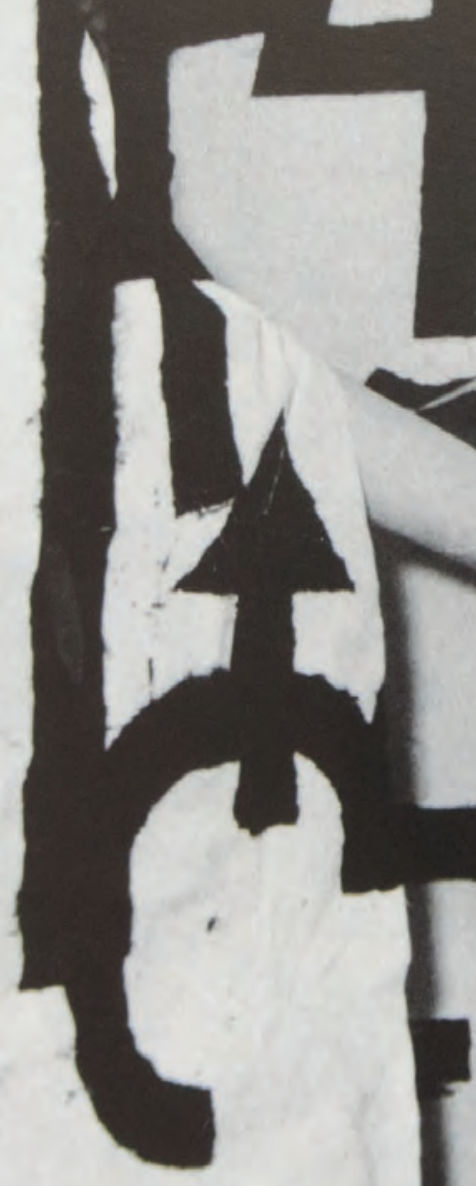


\section{Projeto para escultura em Haia I 997}

Publicado originalmente em Unbuilt Roads: 107 Unrealised Projects, Stuttgart: Cantz Verlag, 1997, p. 62.

Ferrara, 6 de abril de 1997

A escultura deveria ser colocada na frente da nova ala do parlamento holandês em Haia. Meu ponto de partida era a grande e imponente estrutura das chaminés no telhado do antigo edifício do Parlamento. No meu projeto, essa estrutura arquitetônica seria a base de ferro que apoiava meu "objeto de escultura" de 1967, que inicialmente continha algodão, mas essa vez deveria ser preenchida com carvão. No geral, a peça teria sido quase tão alta quanto dois andares do edifício do antigo Parlamento e colocada na pequena praça, de frente para a entrada da nova ala.

Evidentemente, os vários representantes do partido que avaliaram o projeto devem ter percebido que este também constituía uma inovação embaraçosa: o modelo do herói e da vitória, de origem helênica, havia desaparecido. Em vez disso, em termos de espírito e pathos, minha proposição se referia aos Comedores de batatas de Van Gogh, com suas mãos ásperas e desgastadas pelo tempo, iluminadas por uma lâmpada de óleo pendurada sobre seus rostos severos em uma sala humilde. Para mim, isso representava beleza, inovação e justiça. E ainda considero Van Gogh um galhardete intelectual, tanto na sua loucura quanto no seu gênio, a quem não se pode deixar de amar. Então, usando uma de suas imagens como referência mestre, eu tinha começado a criar um monumento que, na minha imaginação, representava a Holanda que eu tinha descoberto através de suas pinturas. 


\section{Para Antoni Tàpies 1997}

Publicado originalmente em Tàpies, Prato: Museo Pecci, 1997, p. 36-37.

Umbertide, $1^{\circ}$ de março de 1997

Falar sobre a civilização camponesa tão claramente retratada por Pasolini em seus textos escritos é também uma referência ao fruto e à expressão de um território cultural; de viver a vida à sombra de uma igreja românica ou barroca ou outra; de pertencer a uma família de artesãos ferreiros capazes de fazer rosas e folhas de ferro forjado, aqueles que são criadores de lâminas e espadas, mas também ourives que sabem bordar heráldica e motivos arabescos em frontões de pedra.

Isso significa conhecer as estradas que podem ser cruzadas à noite e quais os bairros ainda escuros quando o sol está batendo neles. Significa reconhecer as mortes que moldam essa terra, à sombra da catedral, no centro da praça perto da prefeitura; e, apesar desse acessório visceral, permanecer livre para viajar, conhecer os outros, compreender o espírito de renovação e o fato de que as discussões entre diferentes pessoas levam a conceber novas leis em um novo idioma, em formas até agora invisíveis. Isso significa restabelecer tudo nas sombras da catedral, no meio da praça perto da prefeitura. Significa misturar esse solo arenoso com suas cores escuras e profundas do deserto um instante antes de se transformar em deserto; Isso significa raspar isso aqui e aí com uma agulha de ponta seca, dia após dia, como um prisioneiro sem esperança de escapar, naquele calor, na terra seca que causa o deserto e aquelas sombras negras como incisões morais que separam a vida da morte. Eu sou incapaz de interpretar o fenômeno de Tàpies de qualquer outra forma. Meu amigo Antoni Tàpies é o legítimo herdeiro daqueles que pintaram as paisagens de Toledo vistas das janelas, que pintaram os crucifixos vivazes e trágicos; ele é o filho de Gaudì em Güell Park, de Goya em suas pinturas negras; ele é um homem que cultiva um drama e depois enche esse drama de tinta, apesar da conformidade e uniformidade em nossa era do virtual, no qual o drama de hoje não merece destaque.

Falar de Antoni Tàpies é como olhar para a areia do deserto elevando-se em um céu tempestuoso e, caindo com fúria, pintando tudo à mão com a areia. 


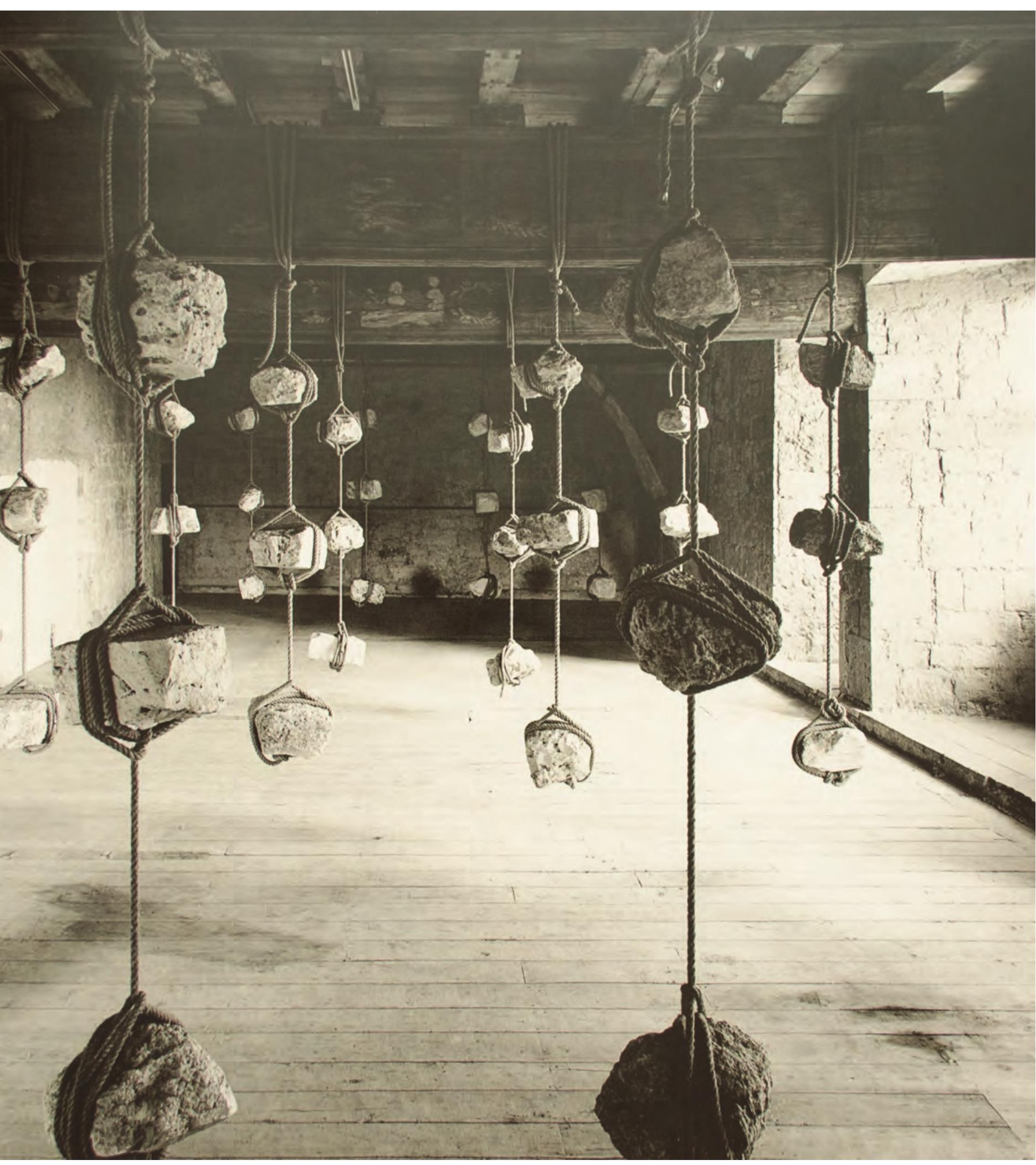


Não se pode falar de monumentalidade 1998

Publicado originalmente em Artecittà: 11 artisti per il passante ferroviario di Torino, Torino: Hopefulmonster, 1998, p. 20-21.

Penso que não se pode falar de monumentalidade para um artista praticando uma linguagem longe de uma formalização na qual não há reflexo da matriz da escultura no sentido clássico da palavra. Não há Balzac para ser apresentado. Mas temos a oportunidade de colocar uma visão imaginária em tal e tal praça ou em tal e tal avenida; uma visão feita de ferro e carbono, tão alta quanto necessária, que serve para refletir o drama da linguagem nascida dos problemas de uma época e, portanto, real.

Por esse motivo, é aceitável colocá-lo ao ar livre como uma representação emotiva e orgulhosa que, a partir desse momento, mantém um diálogo com os demais trabalhos e a paisagem. 

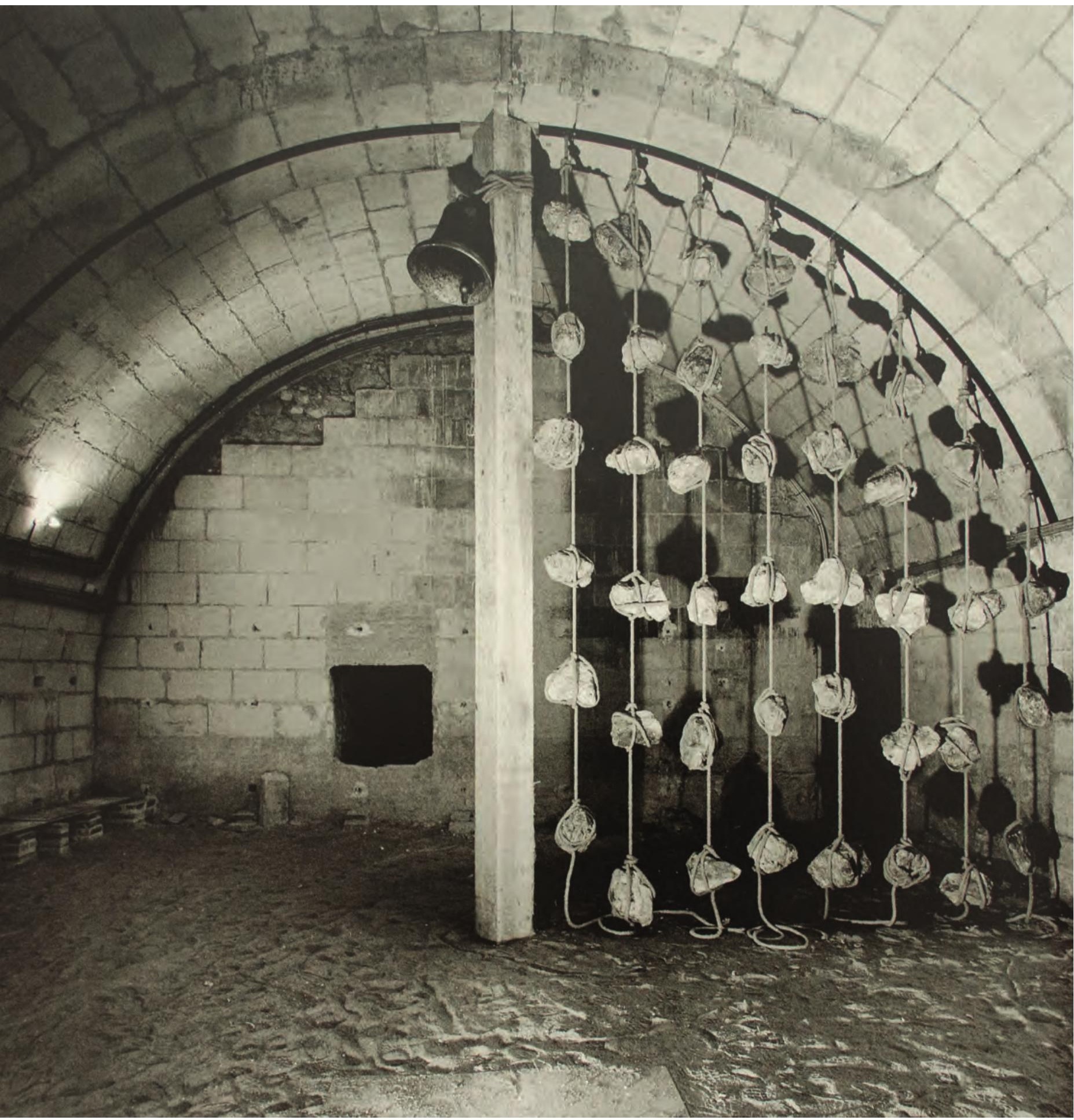


\section{A sociedade europeia que nos rodeia 1998}

Publicado originalmente em Disegni a mano libera, Roma: Opera Paese, 1998.

A sociedade europeia que nos rodeia é, sem dúvida, bastante próspera. Em todos os lugares que você viaja, você vê sinais da força que o poder desta sociedade expressa. Naturalmente, nem tudo é tão róseo. Existem bolsões de pobreza óbvia que são acentuados no contraste entre a brilhante perfeição daquela parte rica do mundo e a miséria e o abandono da parte pobre. Então, viajando para o mundo em desenvolvimento talvez por mar - esses contrastes se multiplicam mil vezes, e a distância entre nós, produtores e aqueles que têm, para dizer o mínimo, uma produção tecnológica menor ou até inexistente, apenas aumenta. Diante desse cenário - sobre o qual somos informados apenas da maneira mais vaga -, um artista, com suas ferramentas e a sensibilidade que o levou a se tornar um artista, não pode deixar de reconhecer o perigo inerente a esse desequilíbrio.

A recusa de gostos decadentes que nos leva a aceitar essa condição sem forma e sombria como algo normal leva a dizer: É isso aí.

É o bastante. Este caminho é muito doloroso. Somos mais uma vez humanistas, esse limite cultural nos pertence; nossa força está no diálogo, em contraste com aqueles que acreditam que o "pós-humanismo" é uma novidade emocionante a ser divulgada nos salões de um "Salò" cínico e conformista. Considere a pólis, com todas as suas perspectivas harmoniosas e poliédricas. É a imagem mais feroz, bonita e apocalíptica do novo que alguém pode imaginar.

173 Detalhe de Sem título, 


\section{Os outros que estavam lá e respirando I999}

Publicado originalmente em Arti Visive/Arts Visuels: Roma 1999 - Sarajevo 2001, Roma: Castelvecchi Arte, 1999, p. 7.

Roma, sábado 22 de maio de 1999

Nos anos 60 e 70, sabia-se exatamente o que estava acontecendo nas galerias de Nova York, os problemas e as formalizações, mas muito poucos sabiam onde estava Liubliana geograficamente e o que esse eremitério perdido e incisivo representava, desde a queda dos muros e o consequente aparecimento de contradições tempestuosas e dramáticas notamos os outros que estavam lá e respirando.

O Mediterrâneo que banha os territórios de grande civilização e cultura: os países árabes, Israel, Turquia, Grécia, Espanha, França, Itália, diante do espelho da água, é uma história que pode ser lida e os contrastes acumulados, às vezes, eles ainda não conseguem expressar um diálogo moderado. Esta bienal da Juventude Mediterrânea pretende ser um ponto de encontro, que contribui para o desenvolvimento de uma atitude artística, o primeiro ato a se tornar um ponto de modernidade, no futuro sem modernismo, garantindo os limites certos que as culturas enraizadas impõem.

Por um lado, é evidente que a identidade, o ponto-focal da credibilidade e da harmonia, deve ser preservada e, por outro lado, através do diálogo e das tensões vertiginosas das quais apenas a poesia é capaz, causar impacto, a fim de encontrar uma frequência comum, e com ela as linguagens artísticas renovadas em um clima que permite que as defesas mútuas caiam, e a curiosidade e o desejo reinem, a única alma da criatividade. Então as diferenças podem ser riquezas e razões para um diálogo profundo. Longe dos falsos modelos globalizantes e das homologações e defesas difusas com uma espada desembainhada, penso precisamente por esse motivo que a Itália e Roma em particular podem ter um papel central e oferecer ao mundo da arte mediterrânea um teatro nivelado, distante das tentações da neutralidade, um terreno para uma nova legenda, oferecendo um ponto fixo para a construção e promoção do debate entre os artistas que representam os povos

174 Sem título, 1977. Miniatura de trem elétrico sobre helicoidal de ferro fixada a um pilar. Estúdio Tucci Russo, Turim, 1977. Foto: Paolo Mussat Sartor. antigos. A exposição Roma, a Ilha de Citera, como na pintura de Watteau, aguarda aqueles maravilhosos viajantes a se redescobrirem amados e amados, como somente as pessoas daqui podem fazer. Finalmente, com a consciência de que há uma guerra que causa dor e desespero às 

populações, gostaria de sublinhar meu pesar dirigido, antes de tudo, aos jovens artistas originários dessas regiões em conflito e que estão aqui hoje para apresentar seu trabalho.

Gostaria também de agradecer a Laura Cherubini, Mario Codognato, Eduardo Cicelyn, Teresa Macrì, curadores especializados com uma sólida preparação e conhecimento das questões artísticas atuais, o mérito de construir este festival é deles. 


\section{Para meus alunos em Düsseldorf I 999}

Publicado originalmente em Echoes in the darkness, Londres: Trolley, 2001, p. 107-108.

Havia uma necessidade de encontrar o apropriado trabalho dramático para criar uma aula em que os jovens estudantes pudessem formar suas próprias personalidades artísticas num idioma nascido da discussão e da crítica.

A Classe Morta, de Tadeusz Kantor, mostrou a importância da noção de uma "classe" e serviu de indicação dramática para revelar a presença de um grupo de jovens, em um determinado momento histórico, no processo de aprendizagem das técnicas apropriadas para essa expressiva construção iluminada pela história. Em outras palavras, uma classe como a nossa em uma estrutura pública.

Durante os últimos cinco anos, repetimos os ritos de ensino e aprendizagem, com a perspectiva de uma "diáspora" inevitável e, eventualmente, um "ego" com um papel de liderança na cena artística atual, tentando transmitir a jornada aventureira em direção a outra coisa.

Todos sabemos que nossas sociedades não são mais as nações do século XIX, e, portanto, o outro, fora e dentro de limites, juntamente com sua diversidade, torna-se crível, torna-se um interlocutor crível.

O que precisamos é encontrar uma maneira de abordá-lo, ouvi-lo, tornarse curioso sobre isso, compreendê-lo quando parecer acessível e tentar formalizar uma imagem que, ao mesmo tempo, também incorpore suas indicações, sua visão de centro, seu senso de dimensão. Nossa abordagem é enriquecida por esse encontro, nascido no livre arbítrio, e é nossa tarefa verticalizá-lo e, em um novo momento com um novo ritmo, descobrir a forma certa para compor esse encontro épico, redescobrir seu drama, o ágil espírito que revigora essa capacidade de respiração possuída por toda imagem verdadeira.

Com essas premissas, esses ideais, como ponto de partida, tentamos dar forma a indicações desprovidas de doutrinas ecoadas que trazem experiências visuais absolutamente diferentes em uma única cavidade. Então, esta é a classe: uma riqueza de recursos e um centro para mergulhar mais profundamente, uma unidade de drama e montagem de desejos fortes para projetar o futuro da forma. Um de cada vez, mostram

177 Sem título, 1966

Mármore com miniatura de locomotiva.

$19,5 \times 20 \times 14,6 \mathrm{~cm}$. Foto: Aurelio Amendola. as suas imagens selecionadas em público, fruto de entendimentos compartilhados sobre o trabalho e de um desejo selvagem de se comunicar. 


\section{O novo não é necessariamente sempre banhado por luz de néon 1999}

Publicado originalmente em Jannis Kounellis. II Sarcofago degli Sposi, Viena: Osterreichischeses Museum für agewandte Kunst, 1999, p. 11.

Viena, 9 de abril de 1999

O novo não é necessariamente sempre banhado por luz de néon. Você pode ver ligeiramente reveladas visões ainda imemoriais, curvando-se à rítmica e trabalhada respiração de uma pessoa que determina o espaço da cena. Ter a animosidade de dizer: "isto é algo novo", despreza o fato de que todo o senso crítico formal foi prejudicado pela uniformidade. Ou para poder dizer, entrelinhas: "Esta é a maneira que eu penso" hoje, quando é tão difícil sussurrar até mesmo um desejo, trocar uma pilha de carvão de um teatro-museu para outro e introduzi-la em outra pilha, aquela massa de pessoas como se estivessem em um anfiteatro, com expressões tocadas aqui e ali pela luz - às vezes verde-escura - pintada e repintada, de pé como em uma corrida num semicírculo em frente ao quadro, enquanto é impresso em suas mentes a inesquecível imagem do touro que deve morrer e do toureiro que deve vencer.

Bam, Bam, Bam, Bam, os soldados entram pela porta à esquerda, em frente ao grande prato de ferro chamado "Trabalho para Budapeste".

Bam, Bam, Bam, Bam, soldados de infantaria invadiram o território da pintura de ferro chamada "Trabalho para o Hospital Psiquiátrico de Viena".

Bam, Bam, Bam, Bam, a cavalaria entra no campo visual da grande placa de ferro com papel branco chamado "Trabalho para o Palazzo Reale".

Bam, Bam, Bam, Bam, os partidários da arte entram pela porta da direita e, depois de uma batalha sangrenta travada mão a mão, derrotam os

178 Vista da exposição Jannis Kounellis, Teatro Attis, Atenas, 2005. Foto: Manolis Baboussis. exércitos inimigos e restauram a pintura ao seu estado antigo e puro.

Para defender insistentemente essa presença monstruosa, aquelas peças desmedidas, pesadas, dispendiosas e ingovernáveis concebidas na Paris de Victor Hugo, a maneira imaginária de fazer coisas contrasta, devo admitir, com os instrumentos de comunicação que todos conhecemos tão 
bem, os que asseguram uma rápida difusão de imagens de um ponto a outro do planeta.

No entanto, apesar de tudo isso, eu ainda apresento meu carvão, meu ferro representando dimensões, os sacos cosidos um a um para criar configurações no espaço. Cada vez que eu os exponho, se redescobre o significado do drama, aquele objetivo misterioso que até agora me concedeu a vida de um aventureiro, mas também me permitiu entender esse inferno como apenas um teatro entre muitos, e reconhecer paixão e dor como um jogo que deixa marcas. Isso me re-desperta e me permite exercitar o desejo de ver e viajar de uma cidade fronteiriça para um centro e além, usando as técnicas que adquiri através da experiência. A redescoberta do espaço gravado é parecida com o couro macio, a progressão das obras colocadas uma após a outra a uma distância determinada pelo ritmo, é a soma das utopias experimentadas no passado e recontada mil vezes.

180 Sem título, 1985. Chapas de metal, base de cama, fragmentos de madeira e estruturas de metal com carvão. $391 \times 575$ cm. Exposição fannis Kounellis, Galeria Nacional, Berlim, 2007 2008. Foto: Manolis Baboussis. 181 Sem título, 1985. Chapas de metal com prateleiras, fragmentos de peças de gesso e madeira parcialmente pintados; sacos de juta e vigas de ferro. $487 \times 964 \times 45 \mathrm{~cm}$. Vista da exposição fannis Kounellis: uma retrospectiva em cinco lugares, Museu de Arte Contemporânea de Chicago, Chicago, 1986. Foto: Claudio Abate. 



\section{Para Adel Abdessemed 1999}

Publicado originalmente Jannis Kounellis, Londres: Phaidon, 2019, p. 139.

Em um momento como este, quando sinais e signos do que conhecemos são veículos de supressão do núcleo onde reside nossa própria identidade, em outras palavras que inevitavelmente suprimem a diversidade, o valor do outro e, portanto, qualquer fundamento para a dialética.

Adel Abdessemed, que conheci em Roma e convidei a participar da Bienal de Jovens Artistas do Mediterrâneo, nos diz visualmente, com a maturidade e violência necessária, que seu orgulhoso e justo universo cultural é uma alternativa à atual tendência de padronização, e, se ele continuar assim, mostrará resultados fantásticos. 


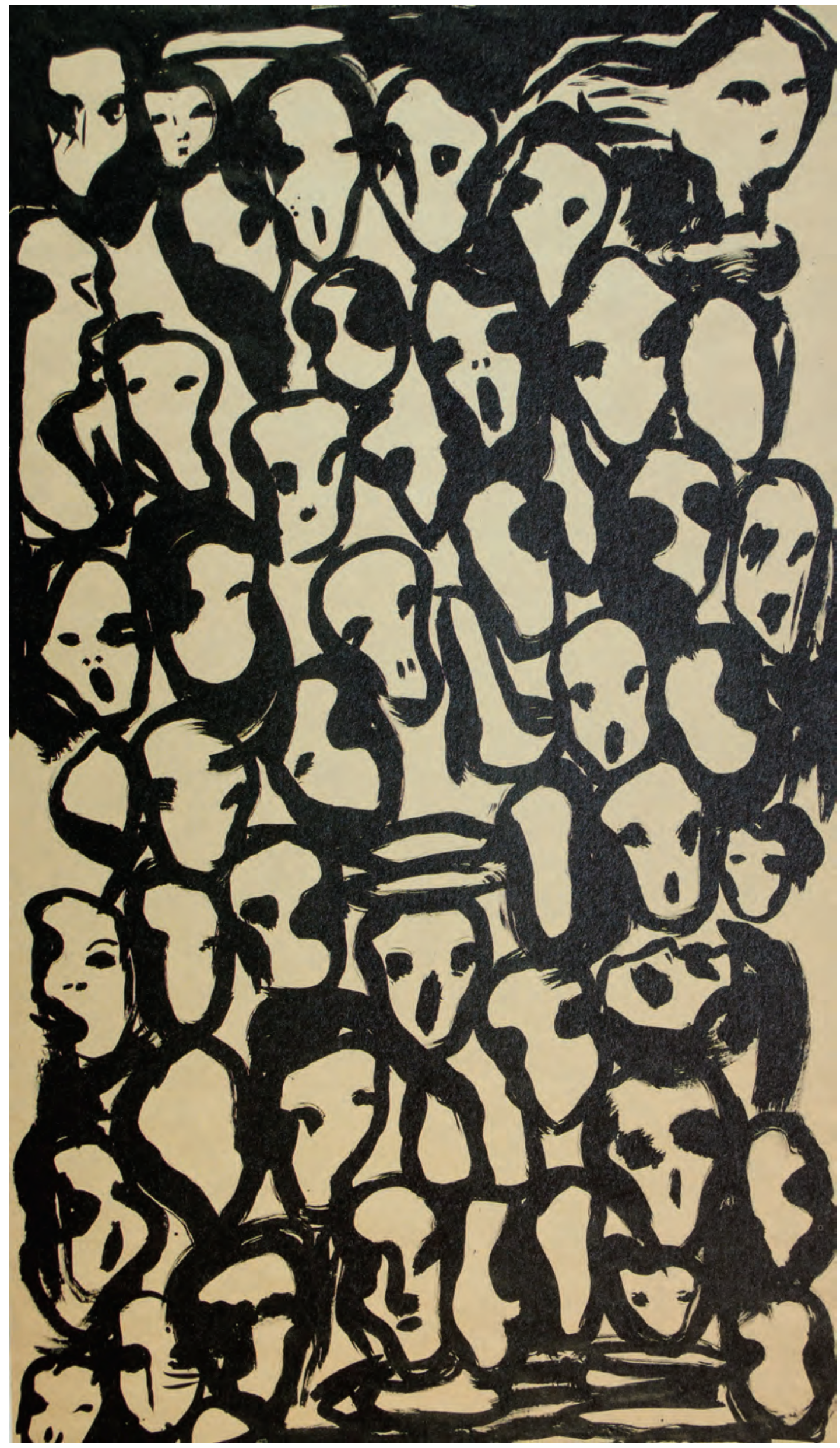




\section{Vamos reviver o coração de Roma 1999}

Publicado originalmente no jornal La Repubblica, Roma, 26 de outubro de 1999.

O uso de um ambiente industrial abandonado foi uma descoberta de pintores nos anos 1960. Indicou uma atração poética, uma abertura coerente para uma formalização artística que havia visto um limite na pintura tonal e destacou o desejo de ter uma história dentro de uma cavidade, considerando que esses edifícios foram esvaziados, como parte de um discurso de abertura e imaginando uma narrativa que partia de uma sombra para alcançar uma coluna através de uma janela brilhante. Essa litania expressiva foi repetida em centenas de lugares da Europa do pós-guerra. Após a descrição literária de Victor Hugo dos subterrâneos de Paris nos Miseráveis, edifícios industriais abandonados carregam uma canção amaldiçoada e um ar pré-revolucionário gravado em suas paredes mofadas, e os artistas se rendem com prazer às delícias desses ambientes vívidos e revividos. O Testaccio, tão ligado à história da cidade, a dois quilômetros de distância de San Pietro, um da sinagoga, dois do Capitólio pode, com sua beleza dolorosa, ter o mesmo destino e inspirar os mesmos amores. Este coração pulsante de Roma, que está inativo há anos, atualmente abriga os carros da polícia. Penso, no entanto, que um lugar tão "especial" pode ter um único objetivo: dar as boas-vindas aos artistas e suas novas pinturas, abraçá-las com calor. E que lugar melhor para artistas solares do que o chão encharcado de sangue sobre o qual repousam suas esculturas. 


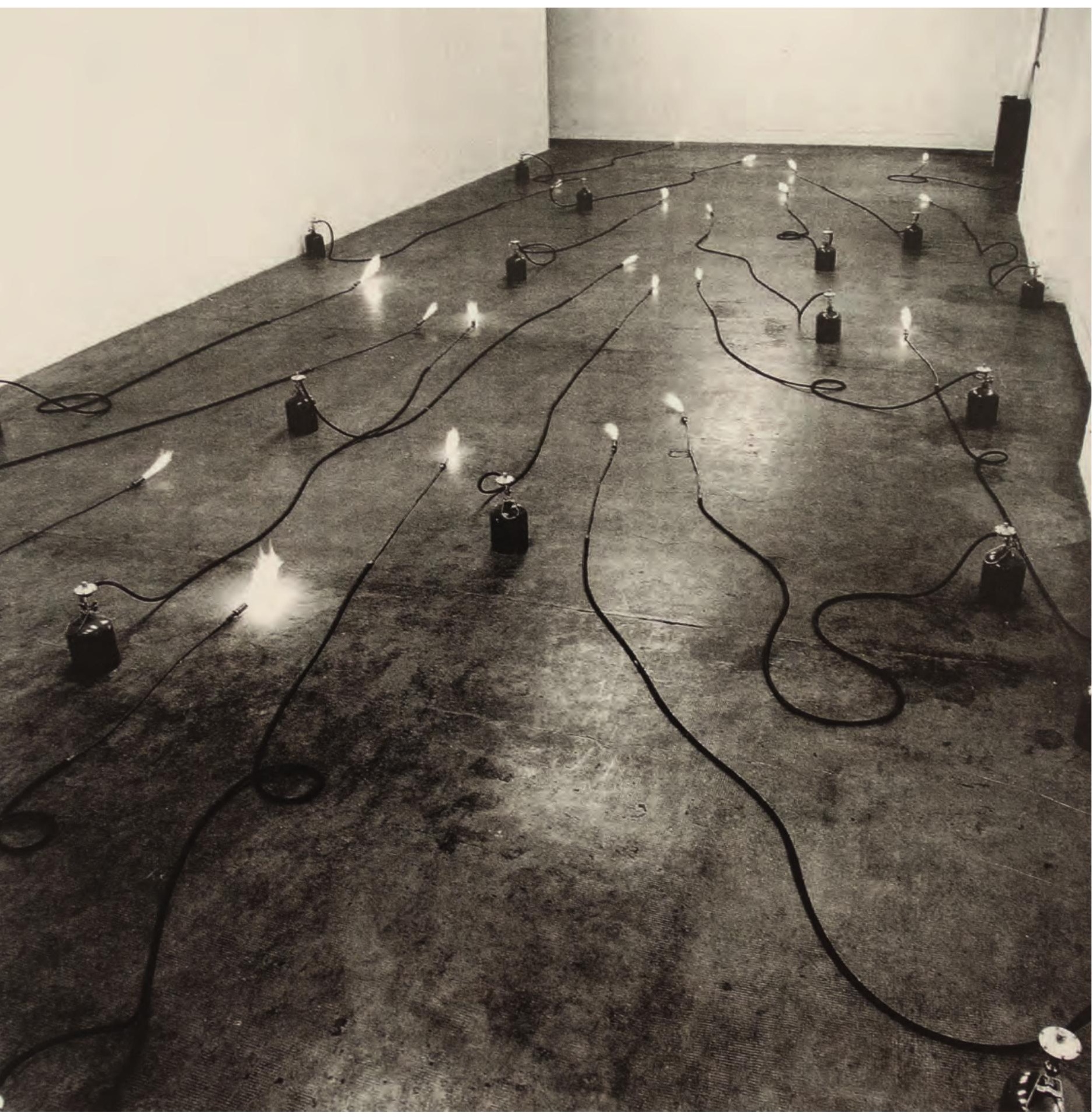




\section{Caravaggio e o poder da sombra 2000}

Publicado originalmente no jornal La Repubblica, Roma, 4 de abril de 2000, p. 1.

Que grande dia de celebração seria se Caravaggio, rei da montanha, soberbo carrasco, com sua espada tirada do anjo guardião do castelo, retornasse a Roma para restaurar a beleza sob uma ditadura oligárquica, para executar aqueles traidores estrangeiros, aqueles que adoram cores planas, aqueles que nunca acreditaram nos poderes revolucionários das sombras, aqueles que não conseguiram ver a luz que determina os volumes, os profissionais intermediários que não percebem, no fundo do poço, o sinal único que separa os limites. Para eles, apenas o exílio, porque a harmoniosa sinfonia, pintada sem descrição, mas com o poder da linguagem, voltará a iluminar o moderno.

O nosso próprio Otelo, voz do povo, príncipe reconhecido por sua diversidade, retornará. Os anjos sombrios, pintados em cores de barro, que se erguem sobre o Rio Tibre na ponte do Castelo de Sant'Angelo em pinturas de Scipione, fazem parte de uma ladainha que antecipa o retorno de todo belo, único, autárquico e independente. Aclamem o príncipe solar sedento de sangue. Que ele venha se vingar daqueles que levaram nossos maiores sonhos à escravidão e assim os desviaram do curso. 


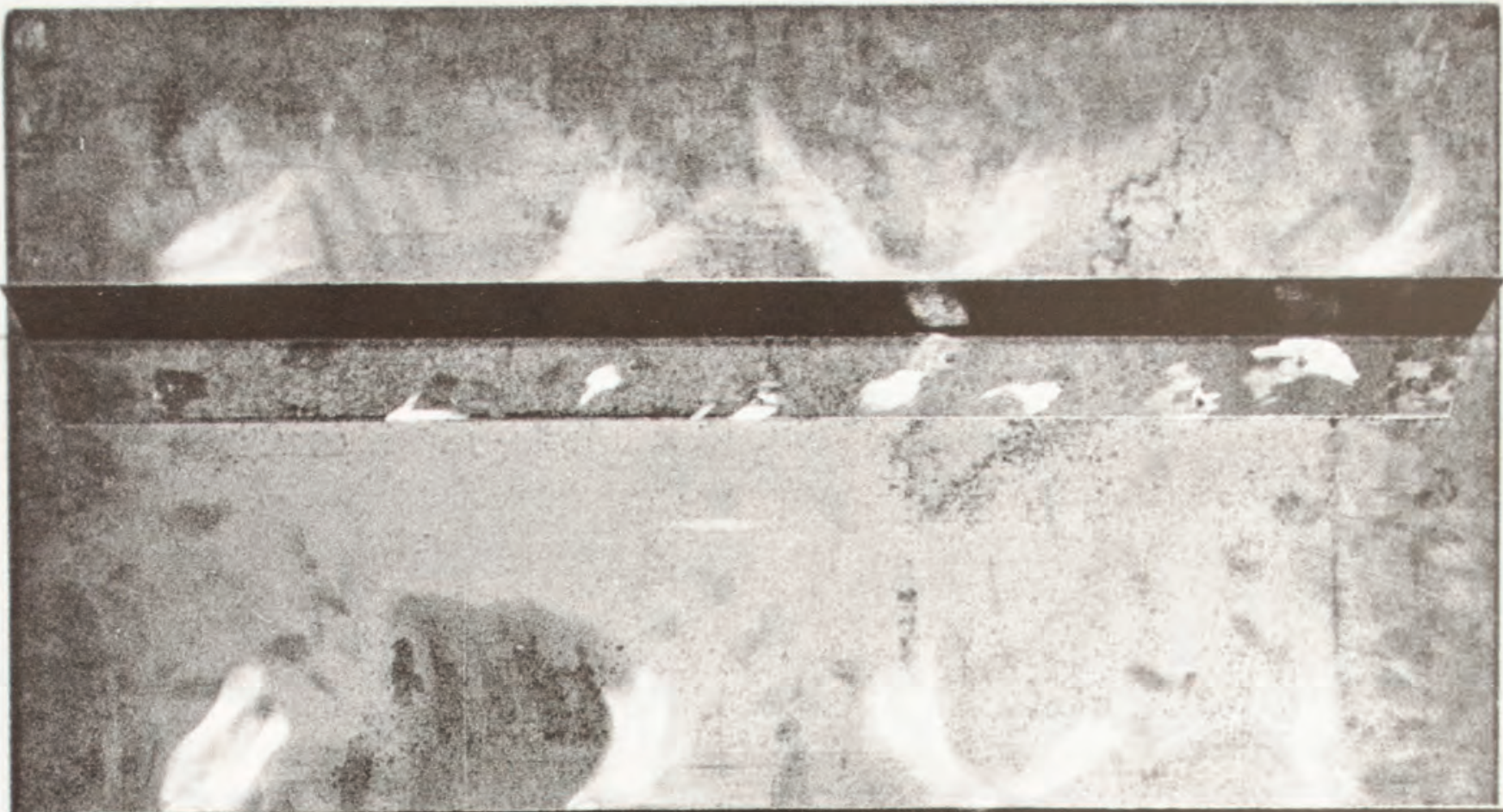
W.

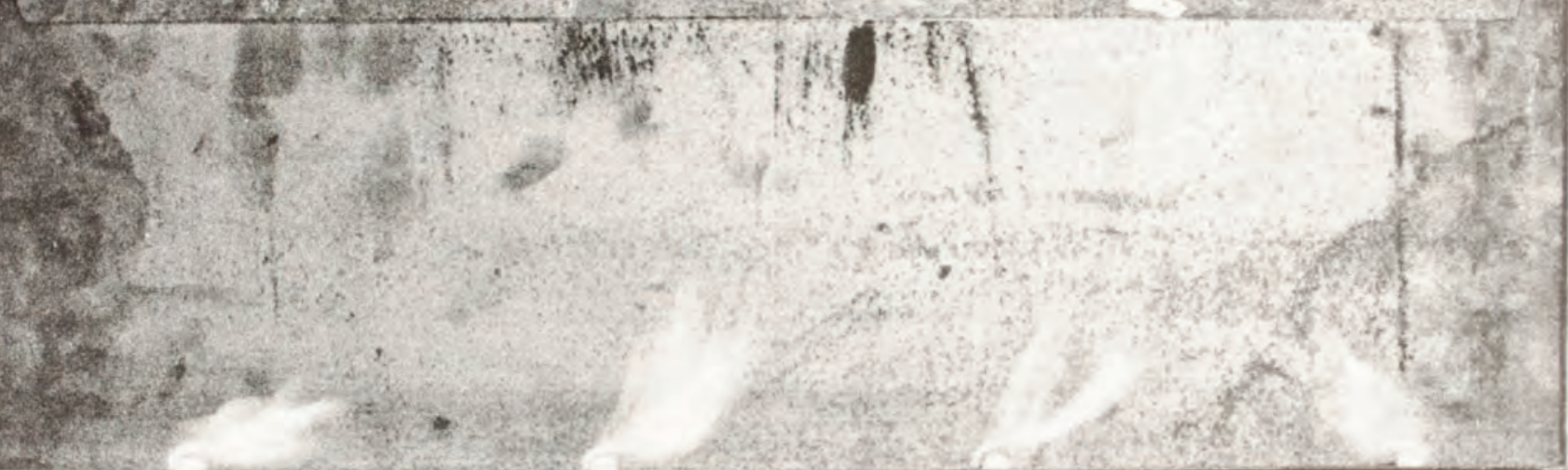

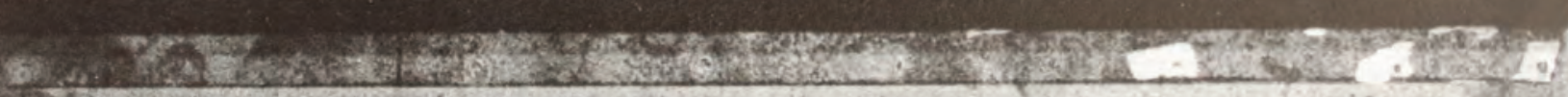

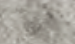

$3 x^{2}+2=0$

$\cos ^{2} \times x^{2}$

2.
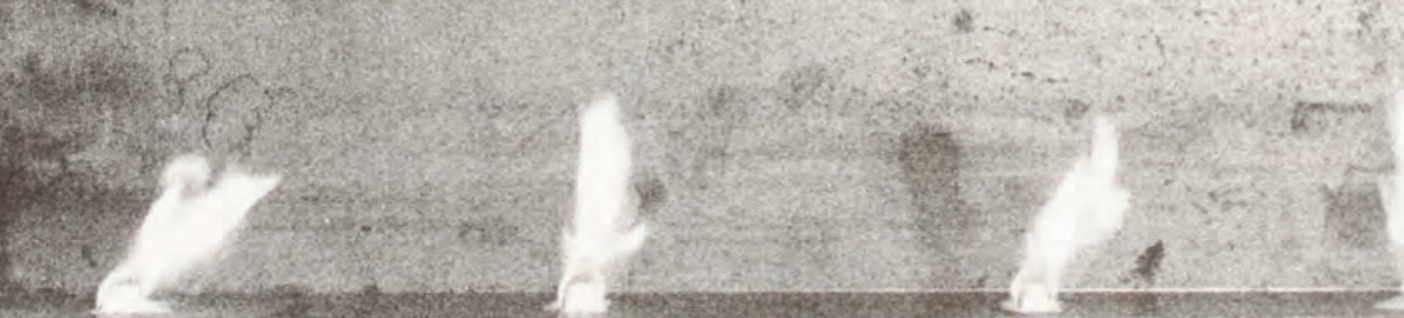

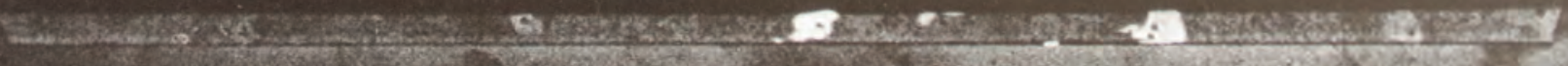
tem 


\section{Um imaginário para narrar 2000}

Publicado originalmente em Sandro Franchina. II fantasma di lato, Turim: Torino Film Festival - Associazione Cinema Giovani, 2000, p. 77.

A ideia de filme de Sandro não tinha essa correlação com a indústria que, por sua própria natureza, o filme exige. Talvez fosse por essa grande afinidade com o mundo da pintura. Isso provavelmente determinou e moldou seu tipo de presença para a produção de filmes que progrediram em um universo lento, contemplativo e único, em que os takes amadureciam dia após dia, incluindo os domingos, como se estivesse em um cavalete.

Não quero dizer uma distância da construção literária, no lugar onde a imagem do filme mantém sua força expressiva, mas, como qualquer arquiteto respeitável faria, ele se certificou de enfatizar que as salas do prédio de frente para o jardim adquiriram substância uma a uma após discussões intermináveis, ataques nervosos, o desejo desesperado de definir outra sala com uma porta, passando por um corredor, levando a outra sala ainda a ser construída. Ele sempre teve uma ideia do todo antes de começar qualquer trabalho, mas sua leitura, sua visão, deu origem a dúvidas e, portanto, a inovações. O tempo necessário para alcançar o objetivo é que cresceu infinitamente e está mais para a quasepintura coberta de poeira do O grande vidro de Duchamp na fotografia de Man Ray. Mas esse pó, mestre sutil que é, ordenou a imagem futura para uma indiferença arcadiana. A urgência não era um objetivo prático para Sandro. Quão afortunado ele era nesse aspecto.

Gostaria de recordar a capacidade muito preciosa de Sandro - tão inexistente nos dias de hoje - de construir um mundo imaginário em que ele pudesse recontar sem ser incomodado, como ele era, pela necessidade opressiva de completá-lo na próxima sexta-feira à tarde. 


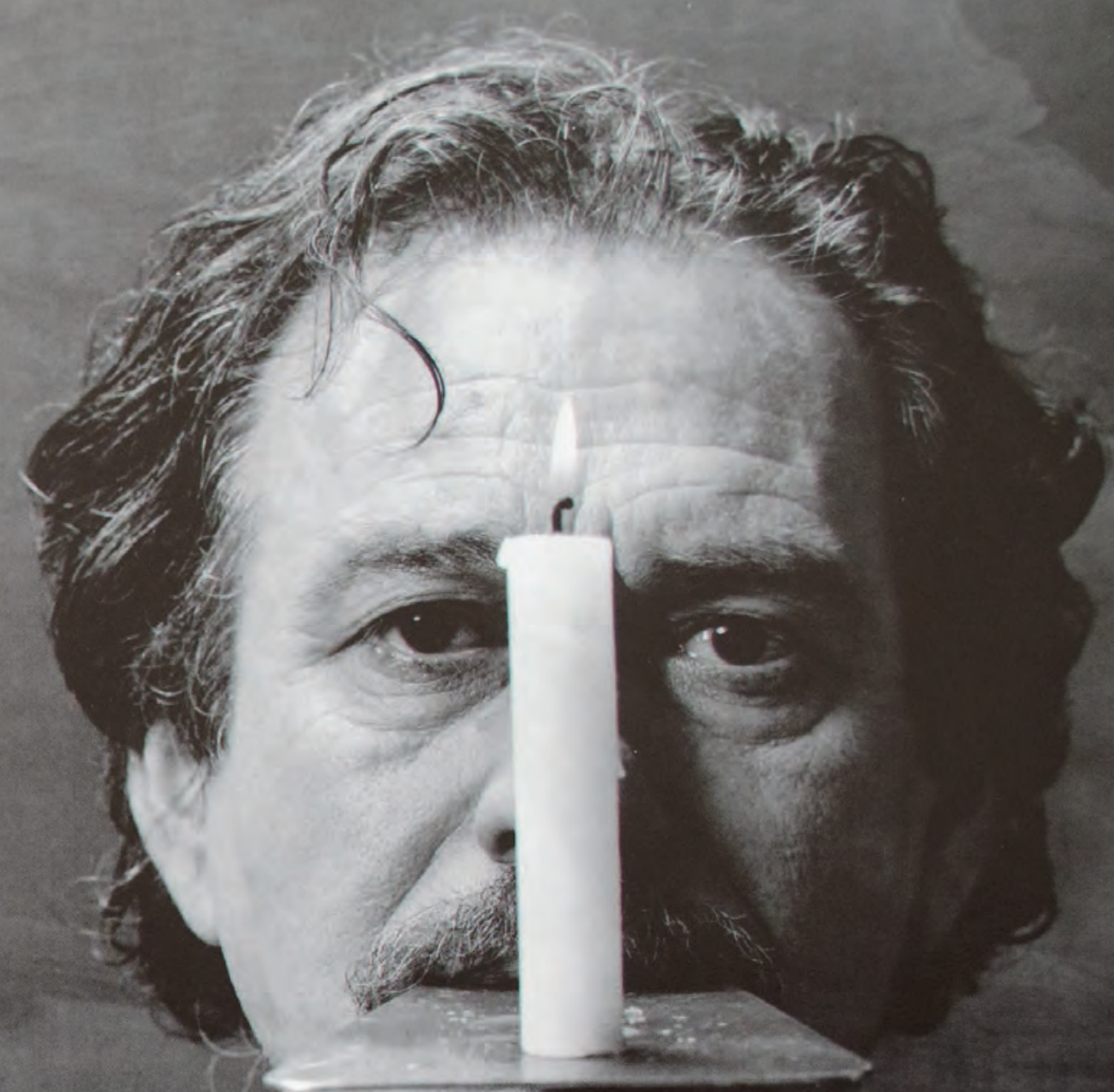




\section{O canto $200 \mathrm{I}$}

Texto para o livro L'Humanité de I'homme, Paris: Cercle d'Arte, 2002. Publicado originalmente em Echoes in the darkness, Londres: Trolley, 2001, p. 115-119.

Umbertide, 23 de dezembro de 2000

A descoberta remonta a uma noite há muito tempo, eu tinha 10 anos ou mais, quando a luz tremulante de uma vela na frente da Madonna e do São Jorge a cavalo permitiu que visse o canto do meu quarto enquanto eu estava sentado à escrivaninha. Pode ter sido o medo que me fez notar o misterioso símbolo do canto, como se a janela e a porta ao lado dela houvessem perdido todo significado e a fuga tornou-se impossível. A presença desse canto cresceu em proporções gigantescas na minha mente e foi tão assustadora que a mera lembrança ainda me aterroriza hoje. Vivo em minha vida milhares de altos e baixos, de uma cidade para outra, uma vez que as condições do meu trabalho exigem isso; todavia, é sempre em locais fechados que os cantos de uma sala se repetem e sua presença determina um espaço e elimina a atmosfera. Esse símbolo mestre, que junta duas paredes e suporta o telhado, é claramente intencionado, por um lado como um espaço interno, como uma longa matéria grávida que acolhe a vida entre quatro cantos, uma arca de Noé para salvar os viajantes exaustos e maltratados; por outro lado, é a invenção-chave para infundir mobilidade e dinamismo em cavidades.

Um canto inspira canais escuros no lugar sagrado onde as forças se encontram e vivem uma existência estática eterna apontando para o céu, a sede de seu ponto de apoio e onde sua criação e destino estão inscritos. Aldeias e cidades são uma fonte interminável de cantos, não aquelas de marcas gravadas no chão, mas essa poderosa força vertical que começa no chão e sobe para o telhado. Vivemos nessa intriga de cantos que molda teatros, os acentos dos dramas reais.

Eu me considero afortunado; durante aquela longa noite e graças à tremulação da luz diante da imagem da Madonna, o canto me foi revelado em toda sua grandeza trágica e, a partir desse momento, as portas e as janelas perderam seus significados e as paredes anguladas, um labirinto prolongado, nunca mais me permitiram sair e desfrutar o pôr do sol.

186 Sem título, 1969. Porta obstruída com pedras. Foto: Paolo Mussat Sartor. Portas e janelas são aberturas, avanços, atos de fraqueza por eremitas que não têm a coragem de se aproximar do centro e capturar a besta sagrada que habita lá desde a pré-história. Essa besta indica o centro e 


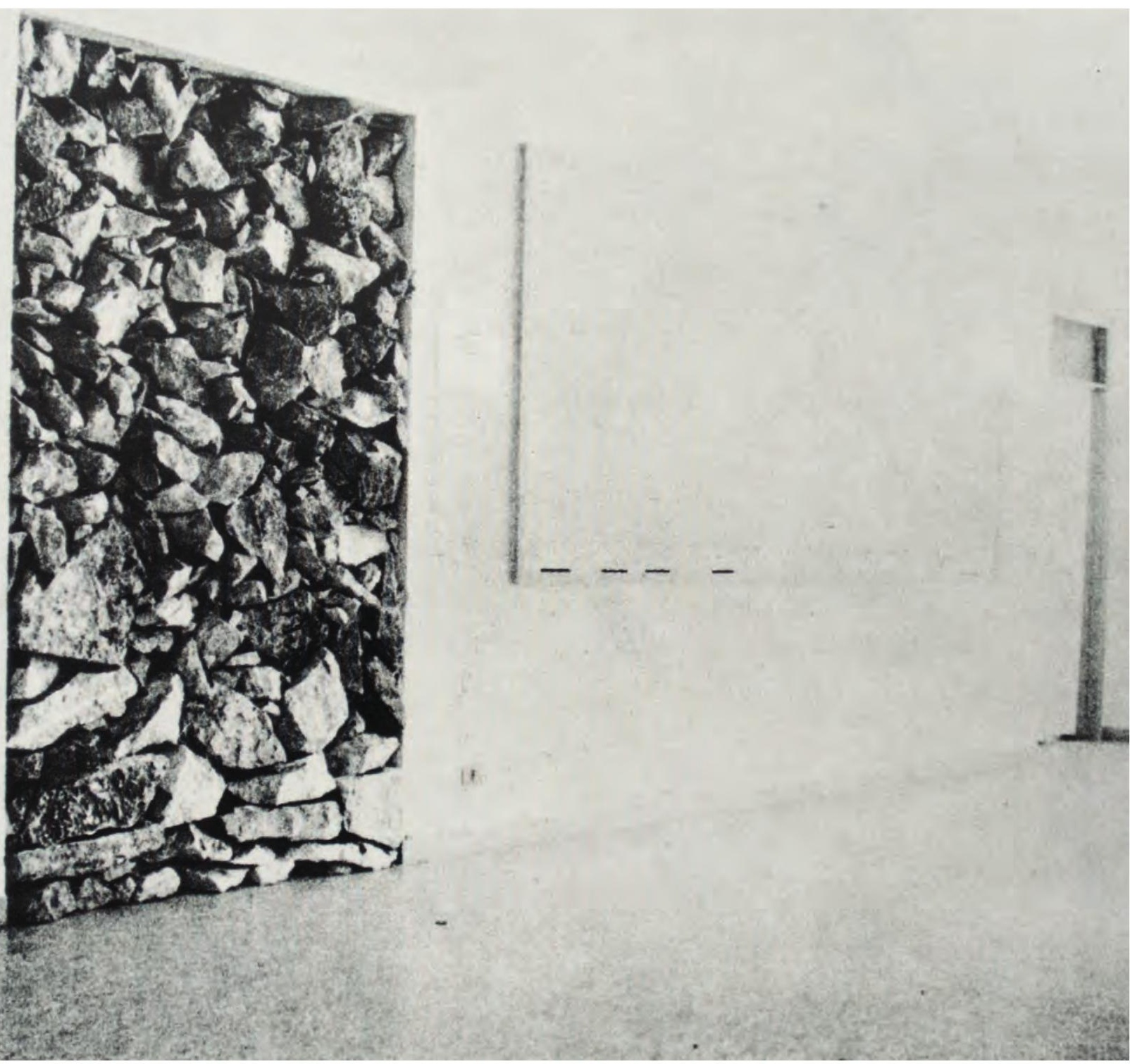


dá um significado profundo à celebração de um sacrifício destinado a recuperar uma liberdade luminosa.

Olhando para baixo de uma montanha em direção a uma aldeia nas planícies, pode-se facilmente discernir a mobilidade animalesca com a qual esse ser vivo escapa do centro, nunca para e com uma gula sem precedentes, graças à invenção grandiosa do canto. Eu entendo e reconheço e, acima de tudo, escrevo sobre isso para superar meu terror, bem como para acentuar (e esta é a minha descoberta) que esses cantos poderosos são o pórtico de um labirinto tão grande que nenhum homem, até agora, vislumbrou algo parecido. É absolutamente inútil esculpir janelas e portas, sugeridas por uma fúria informal cega por um medo do escuro, porque gestos tão aproximados certamente não resolveriam o enigma. O que precisamos é inventar um instrumento de precisão, um navio com velas poderosas anexadas ao mastro principal que nos levem ao centro. Precisamos despertar e reunir toda a nossa energia corporal para imaginar o ar fresco que percorre as paredes desse ponto distante e pouco iluminado, vislumbrado como se fosse um esconderijo secreto no domínio da cegueira. Esse é o instante em que eu gostaria de possuir uma voz fraca, gentil, uniforme (às vezes) feminina, cantar os cantos nus, do meu terror e minha determinação explícita de ser realmente salvo e superá-la, diante de minha descoberta. 


\section{Eu gostaria 2002}

Publicado originalmente em Arte Povera: art from Italy 1967-2002, Sydney: Museum of Contemporary Art, 2002, p. 67.

Eu gostaria (apenas) de ser exilado em uma pequena casa na kasbah de Tlemcen, com paredes caiadas de branco e piso de azul e branco, do tipo que você vê em algumas pinturas de Matisse, com cobertores de lã listrados coloridos, um baú incrustado com madrepérola, um leque para as horas quentes do dia e uma jarra de chá de menta. Neste lugar requintado das Les demoiselles d'Avignon, o da direita, o africano; comer o peixe da natureza-morta de Rembrandt, provar as uvas do Baco de Caravaggio; pescar no barco a remo de Manet; e morrer na glória, como Marat na pintura de David. 
S2)

2. 3 (1)

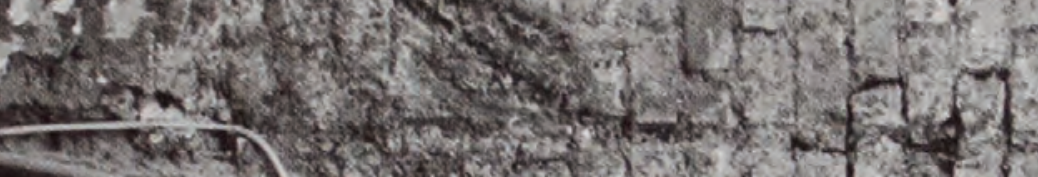

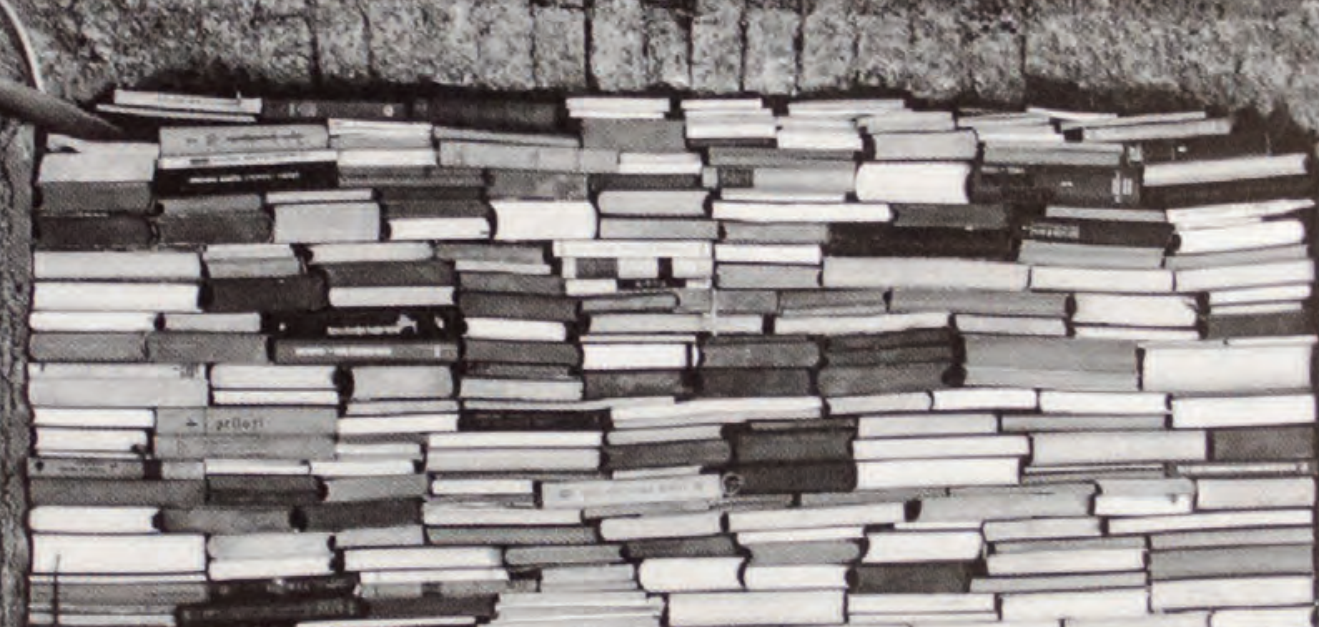

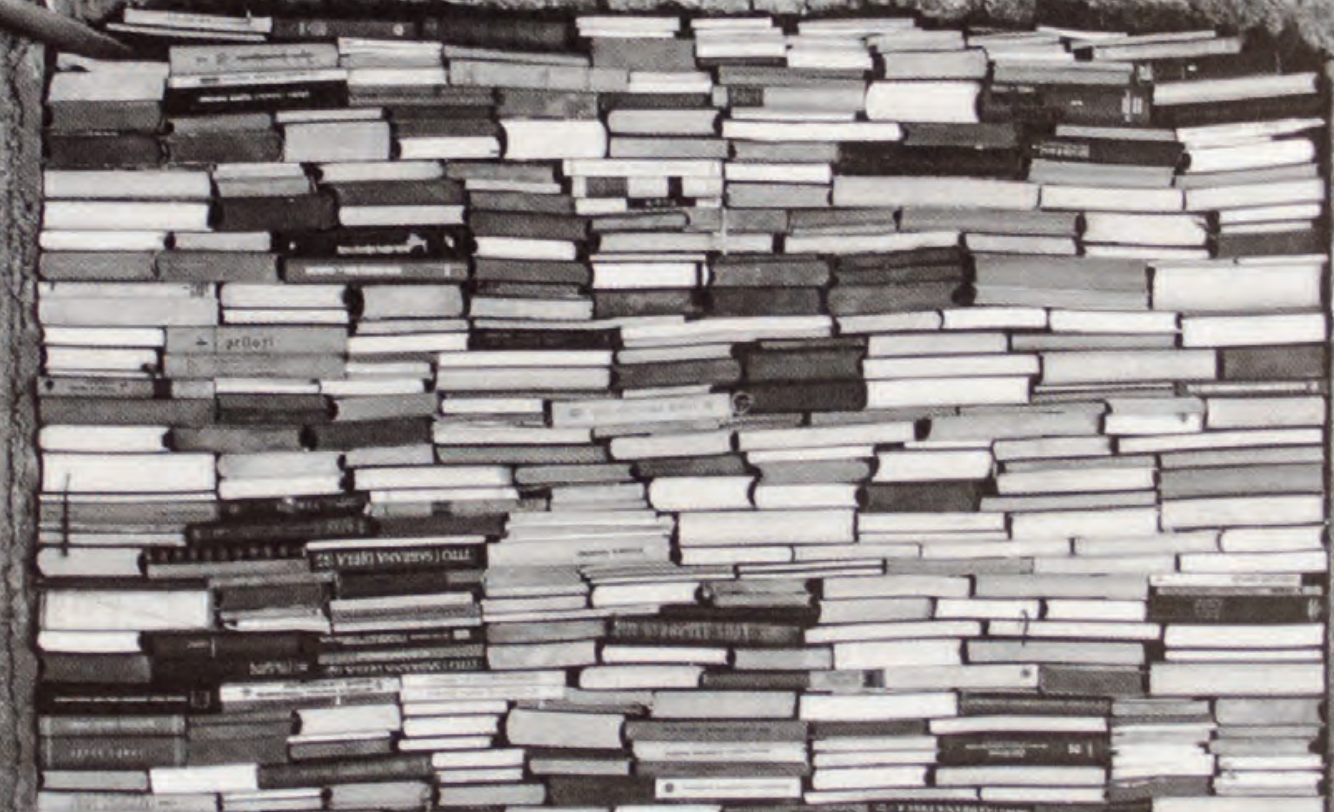

${ }_{n}$

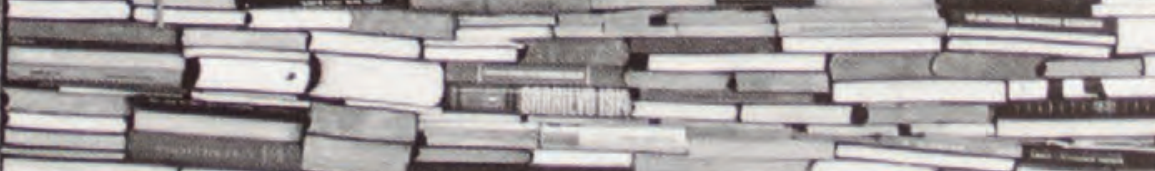
(2) (n)

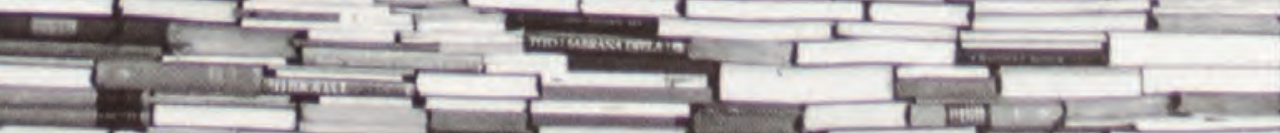

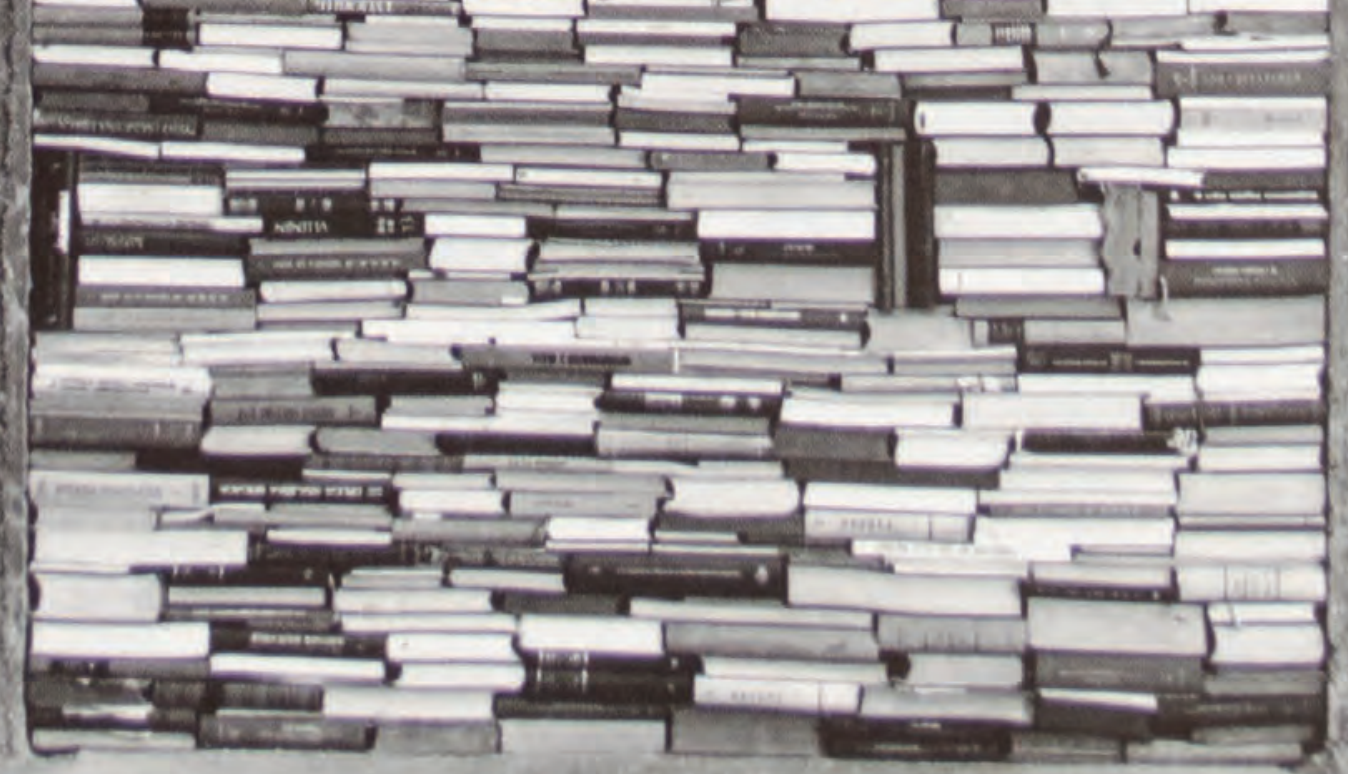




\section{Dúvida, arte e paixão civil 2004}

Publicado originalmente na revista Micromega, Roma, n. 3, julho-agosto de 2004, p. 173.

\section{O QUE A GLOBALIZAÇÃO QUER DIZER}

Vi os eventos se desenrolando atrás das janelas do meu ateliê, mas as mensagens enviadas pelos piratas em uma garrafa não me satisfizeram. Prefiro que, depois de uma viagem, tenha algo a dizer, sussurrar no ouvido de alguém, talvez em uma taberna, esperando ansiosamente por um sinal de aprovação, mesmo que seja de um artista que está morto há séculos, pois encontro nas suas pinturas o seu discurso, goste ou não. Quando viajo, penso em Rimbaud, na Etiópia. No mundo da globalização, você não tem um destino preciso e, portanto, não viaja porque não tem um destino. É bom ir a Hong Kong, mas é aterrorizante pensar em voltar, depois de uma semana, sem ter, pelo menos, conhecido uma pessoa. Hoje passamos de uma maneira convulsiva de uma loja para outra, como os vendedores ambulantes dos anos cinquenta. A globalização é como um lago cujas margens são facilmente atravessadas: acredita-se que os países já não existem mais e o sonho de fazer as diferenças remotamente lembrarem um conflito foi finalmente realizado. Enquanto isso, na América existiu um pintor como Jasper Johns que, há muito tempo, pintou a bandeira americana indicando um centro real. A globalização não questiona esse centro e reduz todo o resto a uma periferia sombria. Estou acostumado a considerar um pintor como protagonista: a condição do artista definida por Picasso quando ele pintou Les demoiselles d'Avignon em um pequeno estúdio em Paris. Considero essa pintura linguisticamente revolucionária: ela não indica um lago, mas um oceano, e não se pode deixar de amar o oceano. Os impressionistas eram nômades, mudavam-se para todos os lados em busca de um sonho de liberdade, o de abandonar seus ateliês e pintar ao ar livre. Os cubistas fizeram o contrário, voltaram ao ateliê para encontrar a liberdade de inventar uma nova linguagem pictórica. Os impressionistas e os cubistas indicam um pensamento forte. Hoje, no entanto, o pintor é o último elo de uma manifestação da fraqueza, também desejada por uma certa política de esquerda, que queria essa perda de relevância. Embora uma volta à pintura tenha centralizado o interesse cultural, hoje é a instituição burocrática

189 Sem título, 1985. Sapatos e maçaricos. Foto: Salvatore Licitra. que oferece a centralidade, mas essa ideia global de pluralidade afasta as críticas e é um discurso nefasto escondido sob uma aparência libertária. 

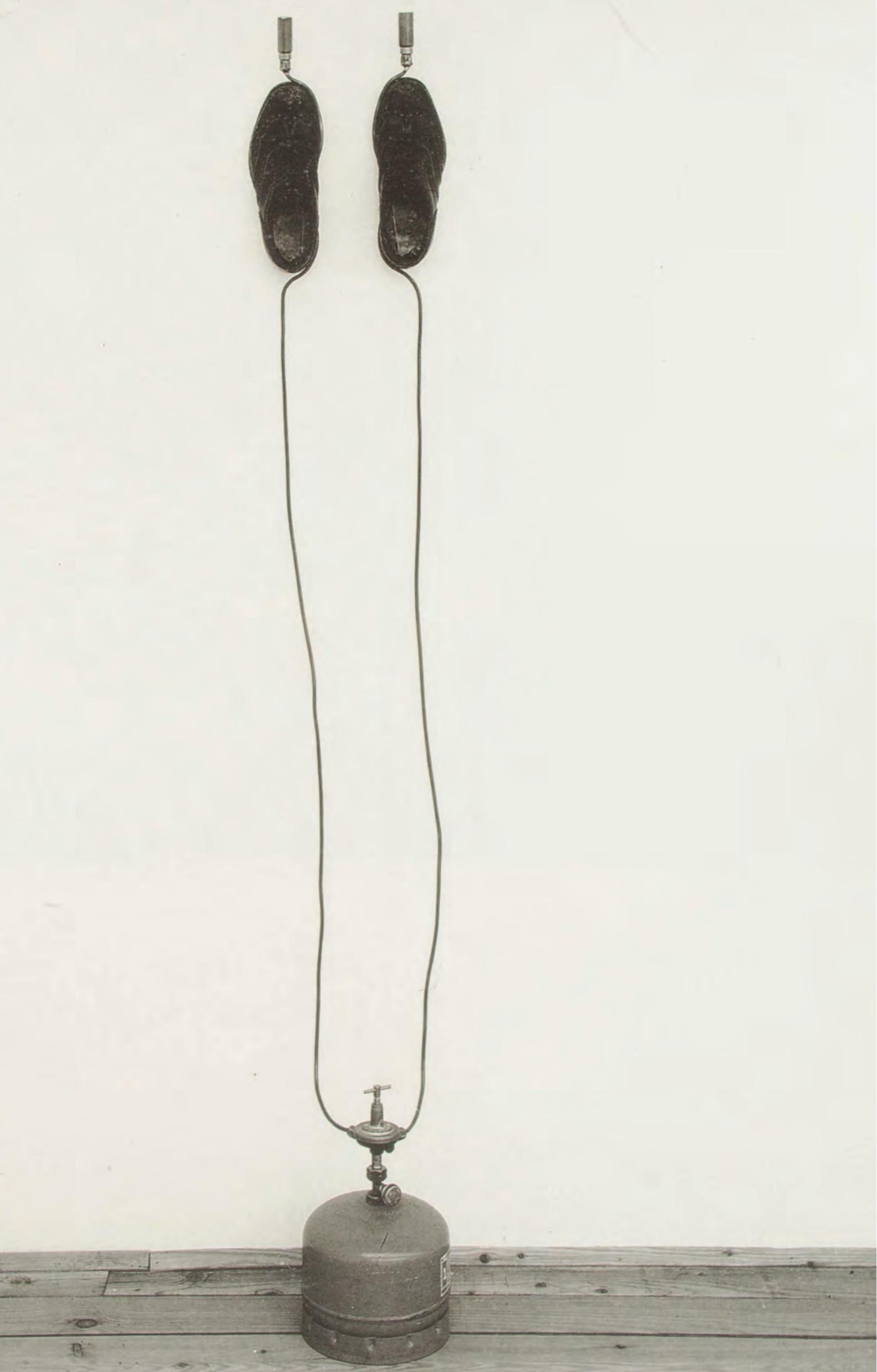
É nesse momento em que o lado laborioso também adverte que é na construção das coisas que o futuro é projetado (o que é uma crítica à sociedade de serviços), que o retorno à vontade de construir e o fim da dispersão não é um sonho que termina, mas um horizonte que se abre.

\section{ORIENTE OESTE}

No Oriente Próximo, há agora um conflito crônico entre os judeus, com os quais temos uma dívida enorme e nunca se deve esquecer disso, e os palestinos, um povo martirizado em busca de uma terra possível. Esta condição paralisou qualquer investimento cultural neste canto do Mediterrâneo. Embora grandes personalidades como Kaváfis, Ungaretti e Marinetti tenham nascido no porto de Alexandria, não se pode esquecer que Atatürk, que revolucionou a política turca e do Oriente Médio, nasceu em Tessalônica. Todas essas costas, de Esmirna a Istambul, de Veneza a Barcelona, foram locais de vibrante atividade comercial e cultural, e a presença de Joyce em Trieste, onde ele escreveu Ulisses, é prova disso.

\section{A IDENTIDADE EUROPEIA}

Em qualquer museu da Europa Central, você vê a identidade europeia pendurada nas paredes pois todos os momentos criativos foram coletados, do neoclassicismo ao moderno. A identidade da Europa moderna se alimenta da diversidade. O europeu não tem a certeza monumental do americano, todas as profundidas tragédias que ele experimentou o levaram a ser crítico. Isso significa ser europeu: cultivar a dúvida, a distância e, portanto, exercer críticas. O europeu não pode ser um homem ligado a qualquer forma de desculpas, como os americanos, que têm grandes pradarias e nos deram uma ideia única do espaço, da qual Pollock é um dos amados protagonistas e com razão. Seu lirismo é profundamente poético e não se desculpa. A Europa nunca terá uma única bandeira, mas muitas, e isso não nos torna menos europeus, mas muito mais. Pintores ideológicos como Masaccio ou Caravaggio marcaram minha vida. Suas pinturas não têm o dogmatismo medieval dos ícones. São pessoas que assinam suas opiniões poéticas e as defendem.

190 Vista da exposição Jannis Kounellis. Navio Cargueiro Ionion, Pireu, 1994. Fotos: Aurelio Amendola e Manolis Baboussis. A modernidade da pintura também está nesta assinatura. A herança visual não existe apenas como história, mas como presença e novidades condicionantes, mesmo as mais extremas, dialogam e reimaginam esses textos fundamentais que são as pinturas e seus signos apócrifos. A globalização certamente serve aos Estados Unidos para não recaírem 

no isolacionismo, e serve às forças separatistas europeias porque cria um álibi para não se unir verdadeiramente. Mas, no que diz respeito à poesia escrita na língua local, é inútil. Na verdade, é bastante prejudicial.

\section{ONDE ESTÁ O POVO?}

As pessoas sempre marcaram os limites e separaram claramente o bem do mal, talvez também tenham encontrado o fundamento por trás da beleza. A política existe como opinião ou emoção. Não foi $O$ Capital de Karl Marx, mas os romances de Dickens ou Victor Hugo que me levaram a ser partidário de quem sofre, a ficar próximo não dos Olimpos ou dos Fêtes Galantes de Watteau, mas dos camponeses de Millet. Hoje, na Europa, não existe mais uma esquerda ou uma direita verdadeira. Opiniões fortes desapareceram, a classe trabalhadora não existe mais e dizem que as pessoas não estão mais lá. Como vivemos sem pessoas? Entendo que podemos viver sem a classe trabalhadora, mas sem pessoas? Toda a nossa tradição pictórica deriva de um conceito popular de civilização camponesa, bem como das Madonas, aquelas pintadas por Ticiano, que usava prostitutas como modelos. É difícil se distanciar do conceito de pessoas. Talvez tenhamos entendido ao longo do tempo que o conceito de massa não era realmente importante, mas o conceito de pessoas é muito importante, todas as coisas nasceram dessa indicação.

\section{TERRORISMO}

Apoiar o cubismo hoje, antes da vontade americana de administrar o século, já é subversivo. Lembro-me de nossas exposições dos anos sessenta, formalizadas fora da tela com uma moldura, que não apenas revolucionaram o aspecto visual, mas também reduziram o suporte da tela a um determinado tipo de forma que acabou representando a conformidade, além de oferecer uma hierarquia de valores diferente. Hoje há uma grande velocidade que matou o tempo, não há mais uma classe média capaz de mediar. Os eventos são tão rápidos que todos vivemos em um terrível paroxismo. O terrorismo surge da complexidade do Ocidente. Nós, ocidentais, oferecemos não apenas produtos, mas também os criticamos. Então, colocamos uma hipoteca pesada nos novos. Outros apenas têm a opção de consumir. 


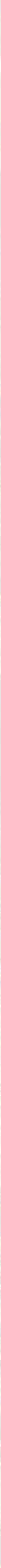


Meu sentimento esquerdista vem de uma imagem, Os comedores de batata de Van Gogh. A esquerda hoje se tornou abstrata, enquanto historicamente nasceu para contrastar a direita e trazer uma moralidade diferente, um conceito diferente de prática civil. Hoje, longe de sua fonte popular, as antigas virtudes vivem nas sombras, mas não se sabe, contudo, em que estrutura piranesiana as depositaram. Então veio a incerteza. Diante do monumentalidade dos anos 20, as paisagens romanas de Mafai nascem da oposição e são de esquerda, mas no que diz respeito à pintura, pertencer a um partido não conta. Hoje, mais do que ontem, é claramente visto que há ligações entre Sironi e Burri pelo menos como uma emoção, como uma capacidade de ancorar-se na Itália, e isso não é um escândalo.

\section{ARTE E POLÍTICA}

Se alguém vive dentro da cidade, percebe facilmente que o poder político deixa sinais visíveis e condicionantes. É difícil de entender o artista que ignora isso. É claro que há a escolha do eremitério, mas fica longe do centro, das casas. Artistas são inúteis. Eles constroem suas imagens com lentidão sem precedentes, levam ao extremo a capacidade de serem compreensíveis através da linguagem e podem ser, para quem os lê, a introdução em uma frequência diferente. Isaac Singer escreveu artigos em í́diche para um jornal judeu de Nova York que tinha trezentos leitores. Ele acreditava que era importante escrever sem levar em conta, como faz um bom pároco do país, ou um artista de vanguarda em suas primeiras experiências de exibição. Grande precisão e pouca audiência, é difícil imaginar o teatro de Beckett dentro de uma arena. Hoje, os políticos perseguem a quimera da globalização com suas técnicas de televisão altamente populares. É preciso dizer que esses museus de quilômetros, projetados com habilidade e destinados a receber milhões de espectadores por ano, oferecem uma ideia de cultura drasticamente contrária ao modelo dadaísta do Cabaret Voltaire. Se, por outro lado, a construção é o que importa hoje, se a era virtual seguiu seu curso, talvez a atitude sutil e aguda que os artistas oferecem, como construtores de

192 Sem título, 2007. Coluna de madeira com sacos de juta preenchidos com café, arroz, lentilhas, ervilhas e sementes. Altura

$350 \mathrm{~cm}$. Foto: Patrice imagens por excelência e capazes de transformar a matéria, possa ser útil ao político: ele oferece o passado em uma placa de prata, remodelada e, na melhor das hipóteses, brilhante e dialética. 


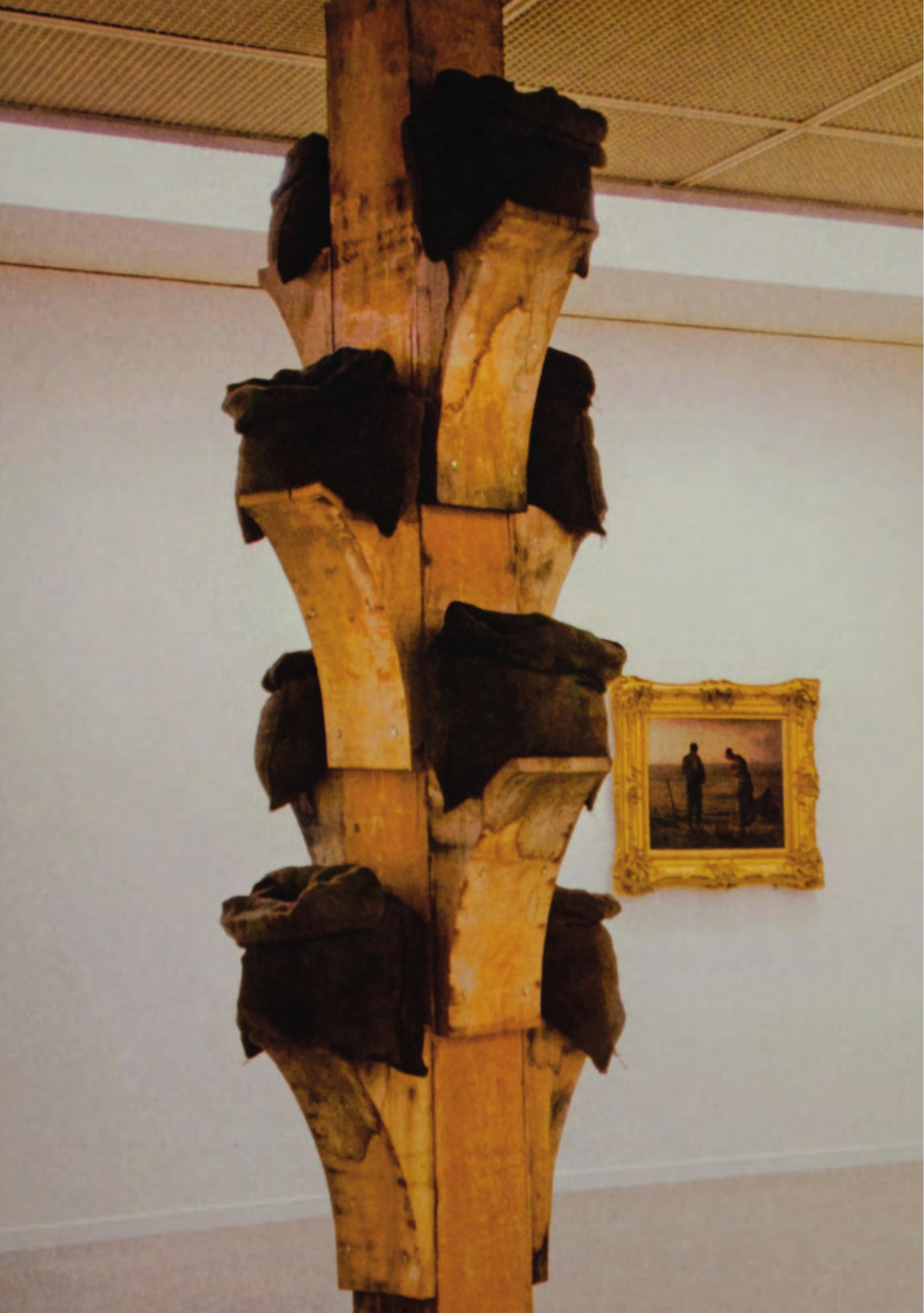




\section{A perda do ponto de vista 2008}

Publicado originalmente em La perdita del punto di vista, Paris: Editions Jannink, 2008.

Tenho manchas de chumbo no meu corpo, tenho trinta manchas de chumbo no peito, tenho manchas de chumbo na testa, tenho manchas de chumbo no cabelo, lembro-me dos dias distantes em que deixei as ondas do lago acariciarem minha pele livre, mas a pele manchada que descobri ontem é a minha verdade autêntica hoje.

Desde 14 de janeiro de 1969, descobri que era um assassino; desde então, sempre que tive a oportunidade, pratiquei minha perversão com um hedonismo decisivo e hoje, depois de tantos anos, acho que essa máscara de liberdade é a minha verdadeira identidade.

As vias aéreas estão fechadas, não posso mais ser um náufrago. O futuro é curto, tenho um grito na garganta, tenho a memória de um dançarino, não me lembro mais da estrada que leva à cidade desde a colina, não me lembro mais da crença em minha fé, não me lembro mais do rosto de minha mãe. Eles me dizem que não há soluções, o cativeiro no meu caso é quase hereditário, mas pacientemente elaboro um plano de fuga.

Atravessamos o Lago Vitória juntos, atravessamos florestas seculares, atravessamos a Etiópia, Eritreia, Egito, Canal de Suez, o deserto, Israel, atravessamos o templo de Salomão, atravessamos a Síria, o Iraque, o Irã, e então talvez outro deserto, e uma grande cidade que fica no fundo do horizonte e, talvez, o Oceano Pacífico, e outra cidade.

Agora que Ítaca está morta, a jornada é pura curiosidade.

Eu te odeio ilha dos mortos, não tenho nada a perder, te espero às oito da manhã no bar do teatro de sempre.

Nesta ilha sem navio, como enviaremos uma mensagem e para onde, e por que relatar sua presença, que bom dizer que $A$ tempestade de Giorgione é verdadeiramente única, vista da ilha.

Dentro da igreja, a pintura parece o fantasma de uma cigana esculpida em uma superfície de alabastro.

Talvez amanhã eu escreva duas linhas sobre o assunto, mesmo sabendo que os navios nunca chegam a esta ilha.

A próxima subida não leva a nenhum oásis, o antigo gólgota carece da figura de Cristo, a cruz de madeira com a escrita latina e judaica, "lesus

193 Sem título, 1982. Vigas de ferro com pedras e fragmentos de estátuas de gesso. Foto: Claudio Abate. Nazarenus Rex ludaeorum", foi pulverizada, ou foi escondida em uma tumba pagã, ou transportada com um navio não se sabe para onde? De qualquer forma, se foi e eu, que sou pintor, perdi de vista esse 


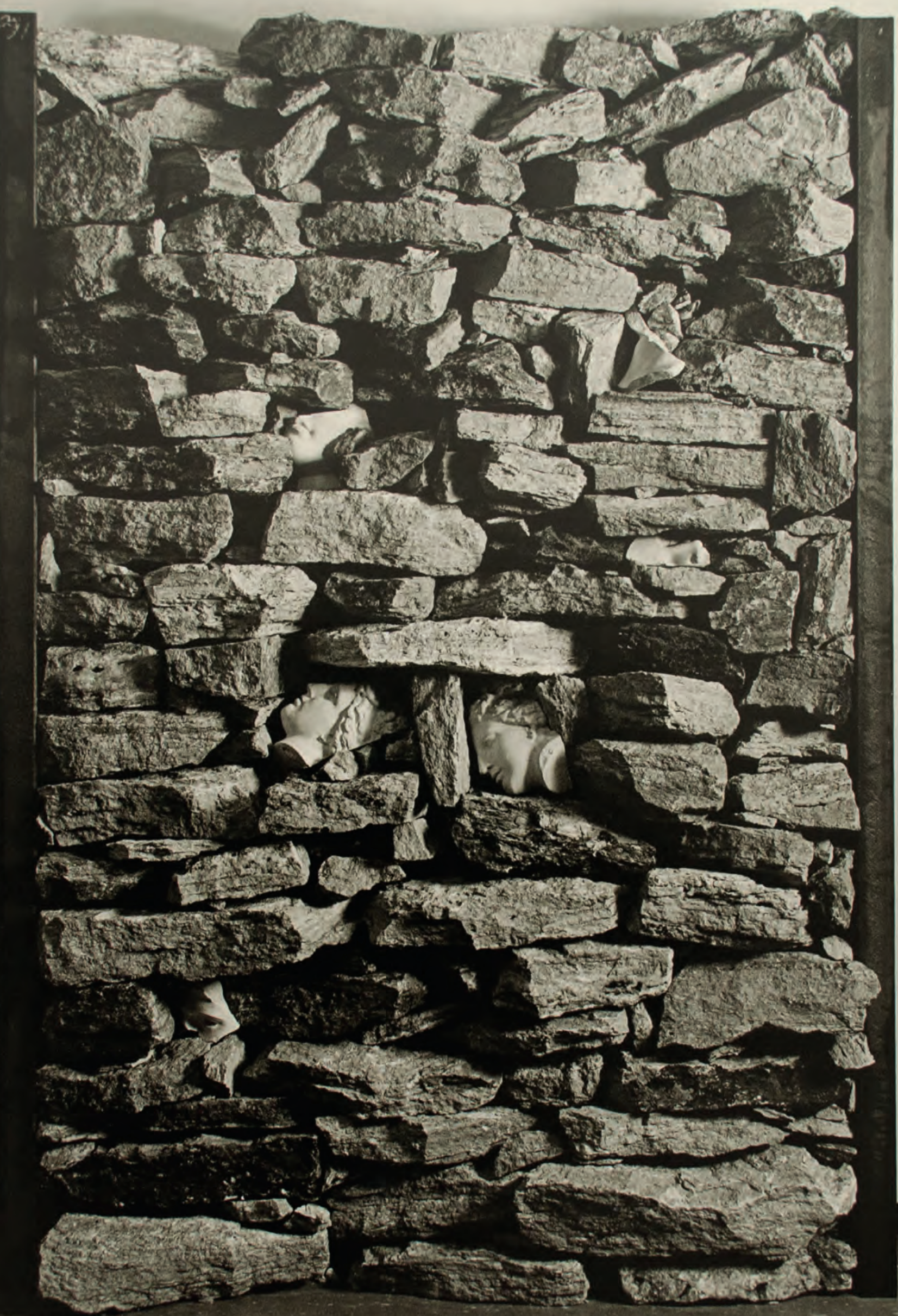


modelo, mãe de muitas imagens, como ainda posso fazer uma pintura, como posso sobreviver sem drama, sem tradição, como posso imaginar a jornada concluída, onde posso esconder a minha lógica um dia, a quem devo dar o desenho mais recente.

Vitória, o tirano está morto, a gaiola ideológica acabou, o fio de ouro, que nasce nas entranhas do labirinto e se perde na memória dos tempos, atravessa mar e montanhas até a porta da casa na Etiópia, até a cama onde dorme Rimbaud, o homem diferente, o novo homem.

Todo mundo diz que fora dos muros existe um mundo animado, as pessoas nas ruas cantam e dançam, há trens rápidos que rapidamente levam pessoas de todo o mundo a pessoas que dançam e cantam em outro idioma.

Dentro das paredes há um cálculo silencioso da lógica, o amanhã está perfeitamente programado, a alegria é calculada como um projeto perfeito, o oxigênio é rarefeito.

"O que fazer", a guerra contra soldados desconhecidos! Conquiste o palácio e quebre as paredes para construir, imediatamente após, paredes maiores para receber milhares de recém-chegados!

Construindo novos rios, novo sangue nas veias, mudando olhos e dentes, mordendo a vida, perturbando o que resta da simetria, dando à natureza o peso que ela merece, sem esquecer que o pensamento é o ponto central da existência.

Você pode esperar: tenho forças para pedir para não desistir do fio umbilical que me une à terra, tenho o rosto que merece, a história foi misericordiosa, o início de uma respiração antiga esculpiu dentro da minha boca.

Que Satanás, de vitalidade e promessas, venceu, para que eu possa dar a ele minha vida sem pensar duas vezes, mas não de graça.

Eu, eu quero o lago na colina que sonhei quando menino.

É do conhecimento público que Van Gogh foi assassinado no trem que o levou de Arles a Rouen, com destino a Eindhoven. Sim, existem trens rápidos como de Marselha para São Petersburgo, mas no retorno sua rota pode mudar, às vezes passa por Zurique e às vezes vai primeiro para Viena, depois para Milão, Turim e, finalmente, Marselha. Outra rota ferroviária vai de São Petersburgo a Berlim, depois Colônia, Bruxelas e termina em Marselha. $\mathrm{O}$ assassinato de Van Gogh, pelo que as autoridades informaram, é obra de um louco, mas nunca acreditei nessa versão, mas na premeditação.

Sempre que viajo de trem, penso nessa atroz "notícia" que afetou profundamente a sociedade artística europeia, pois, isso deve ser dito, libertou os cubistas de uma realidade desconfortável, tornando-a um poderoso fantasma.

Hoje tudo mudou, finalmente não estamos muito inclinados ao drama, a sociedade civil e econômica está globalizada, ninguém mais pensa em assassinar Van Gogh, até porque não existe mais Van Gogh. 

Chegará o dia em que a neve terá um reflexo catastrófico de ouro puro e brilhante.

Chegará o dia em que os corredores de maratona serão os mestres do mundo.

Tentamos dizer "não", como antigamente, pois não queremos aceitar que Ítaca esteja morta, porque esperamos que um monstro ou um santo viva em uma casa semiabandonada, um pintor prodigioso com um desenho positivo para o pensamento, que todos os dias no final da tarde começa a pintar o pôr do sol.

Sua voz é um grito ambíguo entre os freios do trem e as sirenes dos bombeiros, mas ele tem ao seu lado a visão convulsiva do futuro e em suas mãos esqueléticas uma esperança "libertinomórfica".

O quadro é como um edifício, você pode tocá-lo, mas não pode vê-lo por inteiro, você pode vivê-lo, dançar dentro dele, você pode acordar de manhã e reviver as novidades que ele absorve, ele é um canibal feroz, você pode ficar bêbado dentro da pintura, ficando doente e se curando, recomeçando e tecendo um novo caminho, abandonando tudo e recomeçando com um novo ritmo, sempre renovando a dinâmica agitada da revelação.

Depois que você sai do centro, o comprimento de uma superfície é um drama a ser percorrido.

A pintura é uma longa caminhada no deserto que pode terminar com a vida. A vila fantasma desaparece em determinados momentos do dia e volta a existir em momentos de silêncio, quando aparece, a água entra nas fontes, as vozes enchem as praças, os trens chegam à estação, os bancos abrem as portas, os serviços funerários funcionam maravilhosamente... não há nascimentos, eles são inúteis pois as horas entre aparição e desaparecimento são curtas.

Nenhum pintor jamais pintou a vida épica da aldeia, porque não há epopeia, a morte cancela a curta vida da aparição.

É impossível se apaixonar, só há tempo para provar um sorvete. 


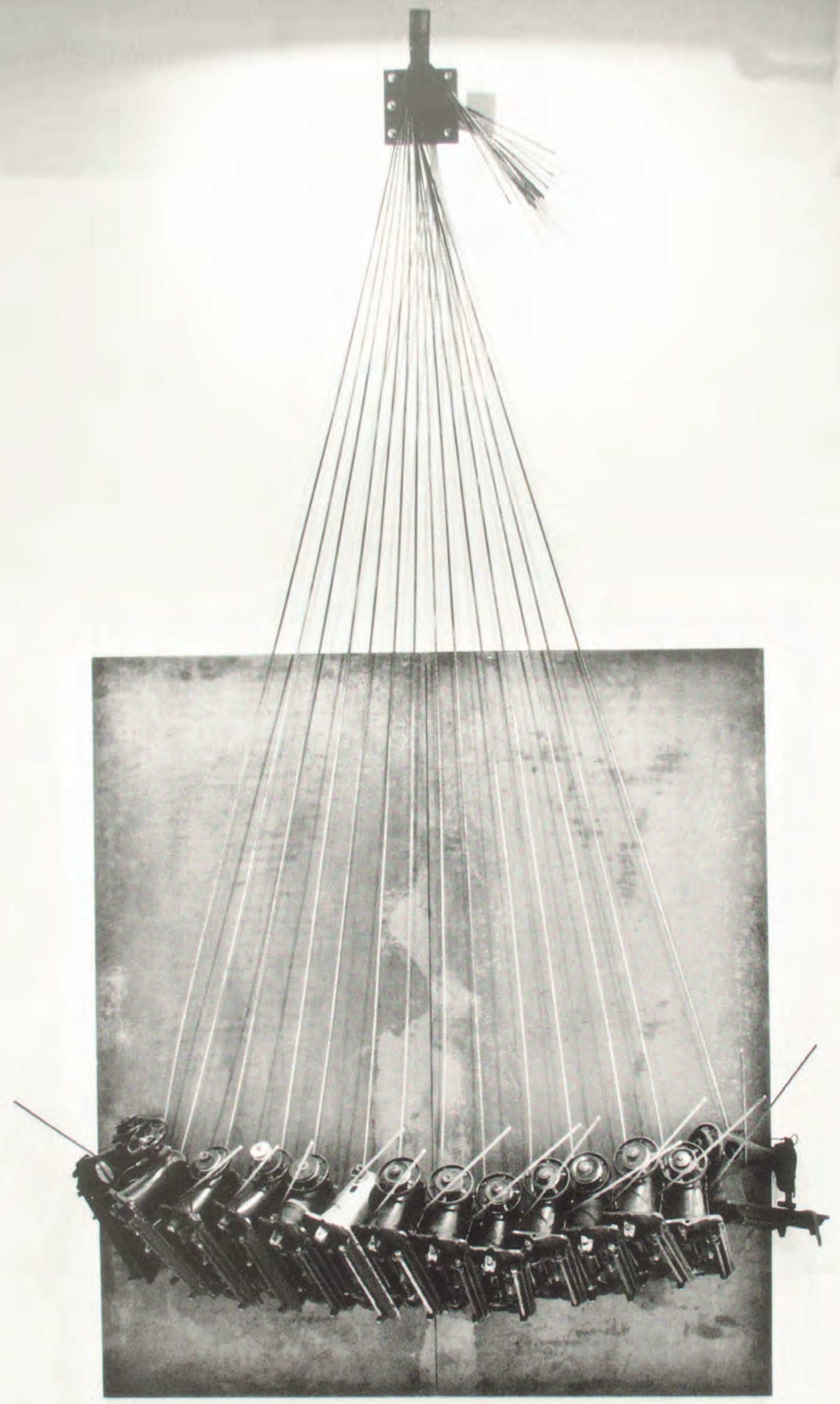




\section{Um labirinto sutil 2009}

Publicado originalmente no convite da exposição Jannis Kounellis, Madrid: Matadero Madrid, 2009.

Um labirinto sutil, sem linhas verticais, a uma altura em que os olhos espiam o construído entre uma coluna e a seguinte, feito por meio da técnica de uma aranha. O ponto de vista está no alto, em uma posição privilegiada, logo abaixo do teto, pendurado em um gancho, imóvel; você pode ver o crescimento do antigo véu (pode ser entendido como um pedaço de material ou algo parecido), o bordado épico criado, ponto após ponto, para formar uma pele forte para capturar a fera mítica que sobrevoa, logo ao anoitecer, esses espaços em Matadero. 



\section{O Embarque para Citera 2016}

Publicado originalmente em Jannis Kounellis, Londres: Sprovieri, 2016.

Roma, maio de 2016

Meu Deus, que catástrofe, e pensar que toda vez que tento pintar tenho em mente $O$ Embarque para Citera, de Watteau, mas a realidade que me cerca é bem diferente, extravagante e dramática.

A sala com fragmentos de casacos ao nível dos olhos, ao longo das quatro paredes do espaço expositivo, tem a mesma agressividade que os maçaricos alinhados ao longo da parede na exposição de 1969, na galeria Iolas em Paris e, também, dos pedaços de carne pendurados em chapas de metal da exposição em Barcelona, 1989.

Além disso, há uma viga vertical no centro da sala que levanta os fragmentos dos casacos até o teto. Eu prometo, no entanto, que da próxima vez, mais cedo ou mais tarde, farei uma pintura inspirada no O Embarque para Citera, de Watteau. 

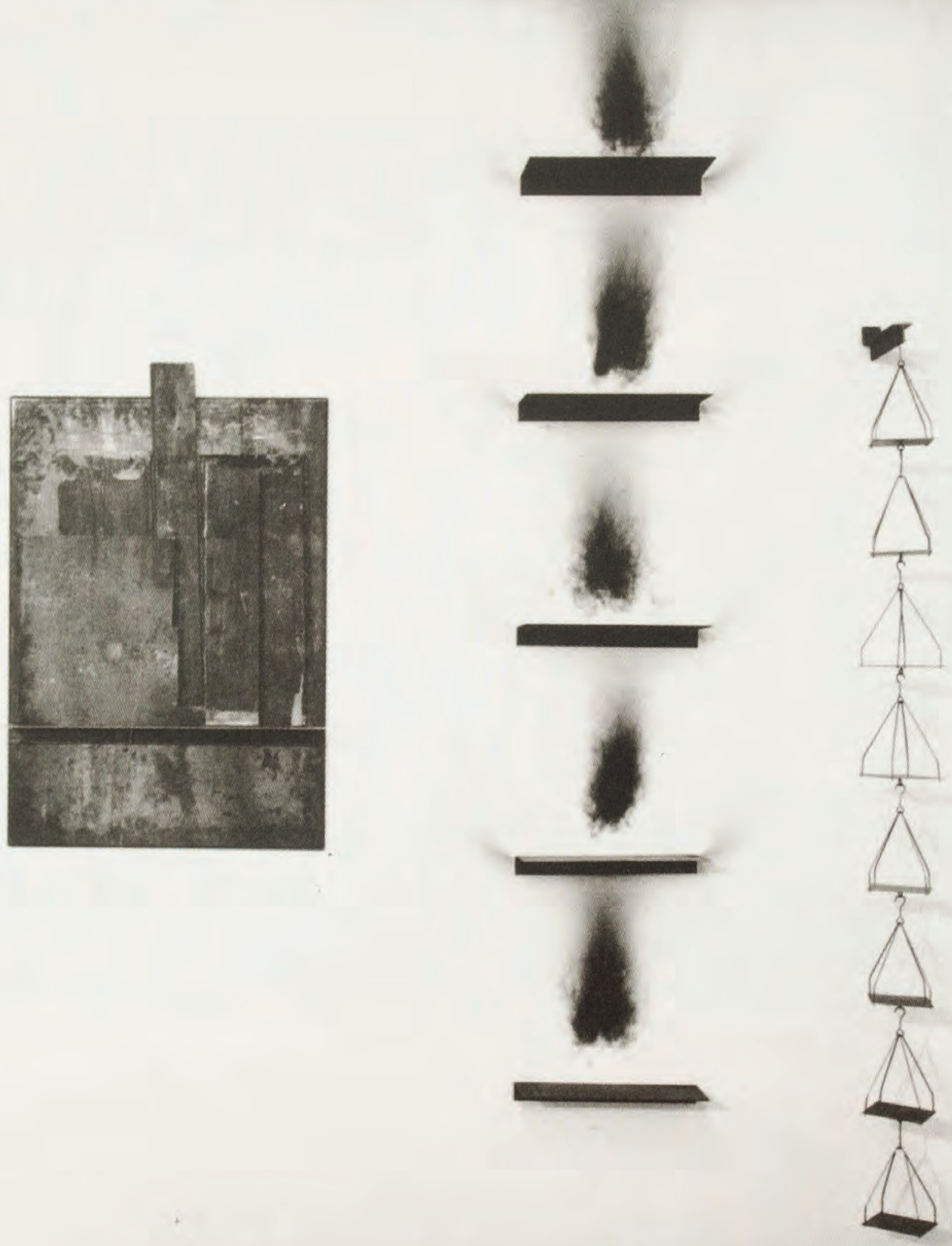


\section{Para David Hammons 2016}

Publicado originalmente em David Hammons: Give Me a Moment, Atenas: George Economou Collection, 2016.

Roma, maio 2016

Querido David,

Estou muito feliz por você estar fazendo uma exposição na Grécia; eu não vou com frequência, mas, como você sabe, nasci no Pireu e o fato de você ter decidido fazer uma exposição em Atenas me enche de alegria. É claro que não me esqueci de nossa exibição de 1993 nos jardins da Academia Americana em Roma, nem o prazer de vê-lo novamente na abertura da minha exposição na Gavin Brown, em Nova York. Se você tiver algum tempo livre, visite o Partenon e o museu arqueológico; não se esqueça, você sendo americano, de que toda a democracia nasceu em Atenas e que a América hoje é o seu porta-estandarte. A filosofia estabeleceu a centralidade do homem, você pode ver imediatamente que um monumento como a Grande Pirâmide está fora de lugar e que, como alternativa, a ideologia do metro e da medição em nossa cultura ocidental é dominante. Além disso, você deve admitir que Vênus é retratada como uma linda mulher. Todos nós apreciamos essas noções e devemos protegê-las e lembrá-las. Tenho certeza de que, se seus novos trabalhos acabarem incorporando cores e materiais locais, eles incluirão, sem dúvida, pelo menos uma pequena dose de alma grega.

Como artista, espera-se que você seja dialético - ofereça alguma América, pegue algo que você gosta da Grécia, jovens artistas visitando sua exposição, e muitos deles bons, verão isso como uma oportunidade para discutir a tragédia da forma nesta era da globalização, que nos afastou da visão vertical que provocou uma mudança tão vertiginosa na arte moderna. Mas seria uma pena renunciar ao velho ditado de que "a vida é linda": então, se você tiver um momento livre entre as obras, vá em direção ao mar e dê uma olhada no pôr do sol.

Boa sorte, Jannis Kounellis 


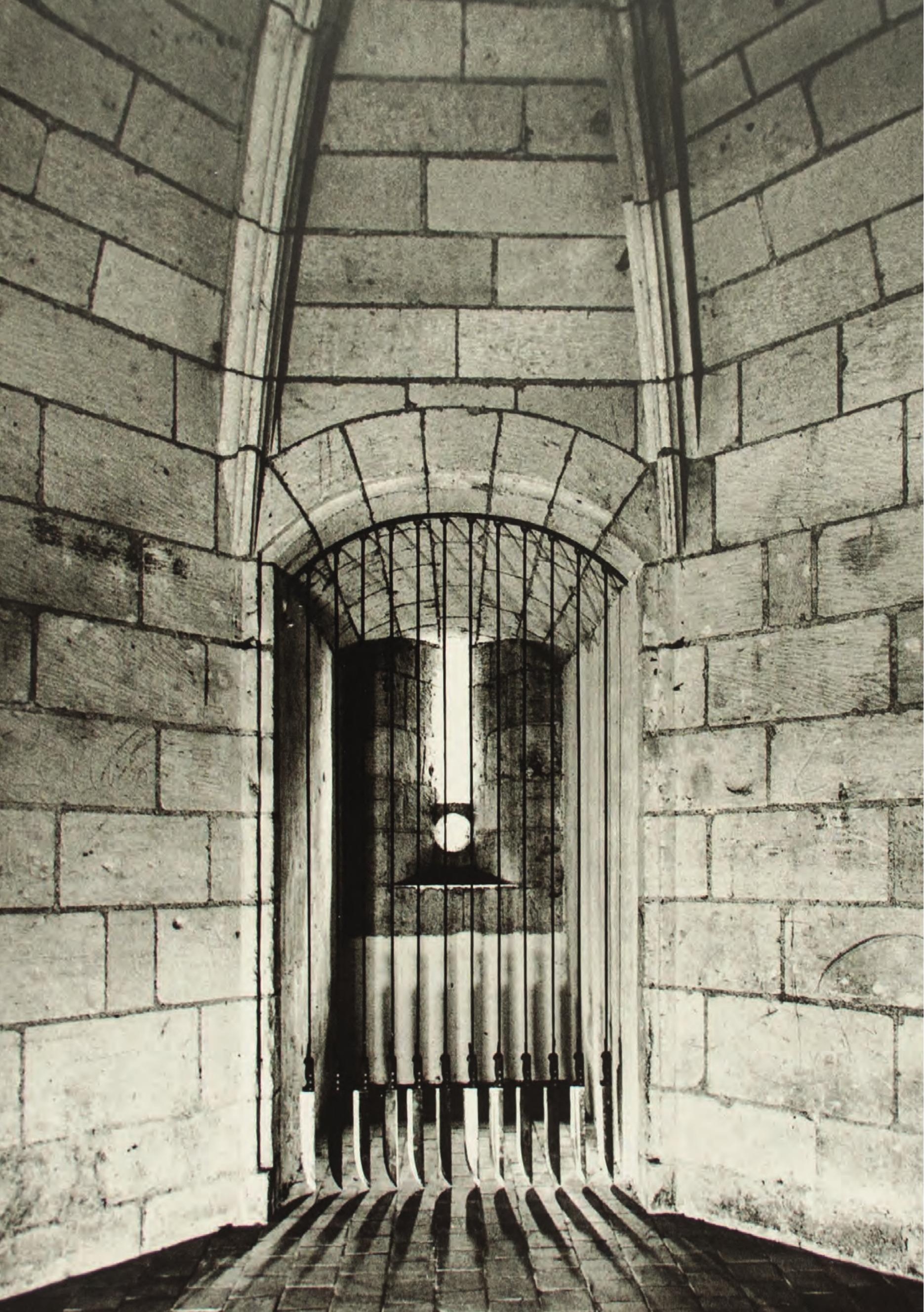




\section{Dodecafonia 2016}

Publicado originalmente no material de divulgação da exposição Dodecafonia, Gavin Brown's Enterprise, Roma, 2016.

Qual seria a melhor maneira de realizar uma viagem: um camelo ou um barco? Como todos sabemos, em ambos os casos, olhamos para o céu em direção à constelação da Ursa Menor para traçar o caminho até o objetivo final.

Para mim, o caminho do mar é muito mais natural para chegar ao destino, seja próximo ou distante, impulsionado pelo desejo de ter um diálogo numa língua ali então inventada, mas nunca esquecendo suas raízes, enterradas sob uma pilha de pedras, numa fábrica têxtil abandonada no inverno de 1907. 


$$
\sqrt{90}
$$




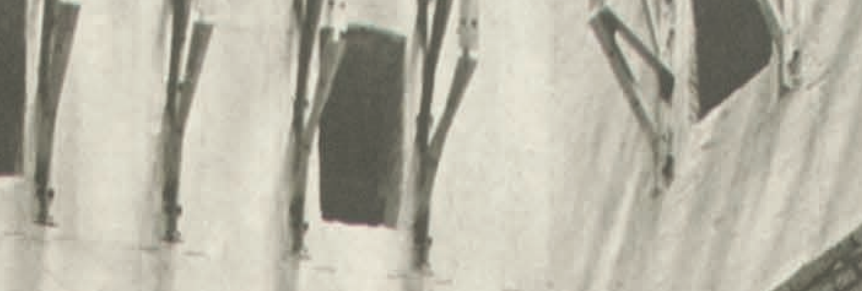

(wos)

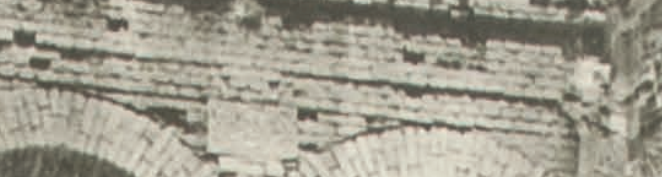

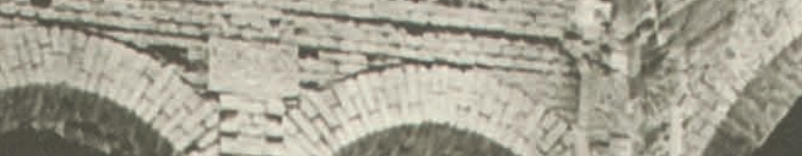

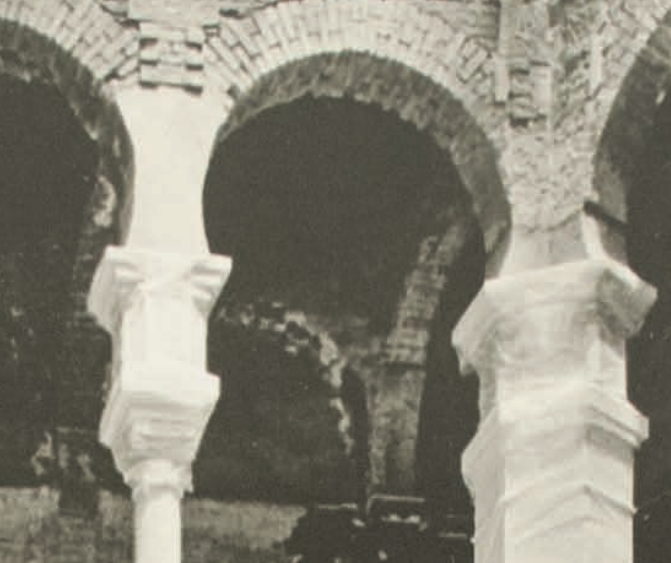

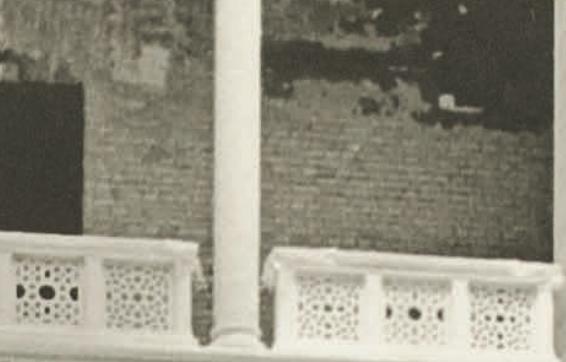

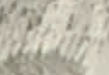




\section{Bibliografia}

ABBAGNANO, Nicola. Dicionário de filosofia. São Paulo: Martins Fontes, 2000.

ARGAN, Giulio Carlo. História da arte italiana. São Paulo: Cosac Naify, 2013. 3 v.

BELTING, Hans. Antropologia das imagens. Lisboa: KKYM, 2014.

BACHELARD, Gaston. O ar e os sonhos. São Paulo: Martins Fontes, 1990.

BACHELARD, Gaston. A terra dos devaneios da vontade. ensaio sobre a imaginação das forças. São Paulo: Martins Fontes, 1991.

BACHELARD, Gaston. A poética do espaço. São Paulo: Martins Fontes, 2008.

BANN, Stephen. As invenções da história: ensaios sobre a representação do passado. São Paulo: Ed. Unesp, 1994.

BATTCOCK, Gregory. Minimal art: a critical anthology. London: Studio Vista, 1969.

BATTCOCK, Gregory. A nova arte. São Paulo: Perspectiva, 2004.

BELL, Julian. Uma nova história da arte. São Paulo: Martins Fontes, 2008.

BOIS, Yve-Alain. A pintura como modelo. São Paulo: WMF Martins Fontes, 2009.

BOIS, Yve-Alain; FOSTER, Hal; KRAUSS, Rosalind E.; BUCHLOH, Benjamin H. D.;

JOSELIT, David. Art since 1900. London: Thames \& Hudson, 2015.

BOIS, Yve-Alain; KRAUSS, Rosalind E. Formless: a user's guide. New York: Zone Books, 1997.

BOIS, Yve-Alain; NUNES, Leonardo. Entrevista com Rosalind Krauss. ARS, São Paulo, v. 16, n. 34, p. 29-54, 2018.

BORGES, Jorge Luis. Borges oral \& sete noites. São Paulo: Companhia das Letras, 2011. BRANDÃO, Junito de Souza. Mitologia grega. Petrópolis: Vozes, 2007. 3 v.

BUXTON, Richard. Imaginary Greek: the contexts of mythology. Cambridge: Cambridge University Press, 2000.

CARDOSO, Elis de Almeida. O léxico no discurso literário: a criatividade lexical na poesia moderna e contemporânea. São Paulo: Edusp, 2018.

CABANNE, Pierre. Marcel Duchamp: engenheiro do tempo perdido. São Paulo: Perspectiva, 2002.

CALVINO, Italo. Seis propostas para o próximo milênio. São Paulo: Companhia das Letras, 2012.

CALVINO, Italo. Mundo escrito e mundo não escrito. São Paulo: Companhia das Letras, 2015.

CAUQUELIN, Anne. A invenção da paisagem. São Paulo: Martins Fontes, 2007.

CELANT, Germano. Appunti per uma guerriglia. Flash Art, Milano, n. 5, 1967.

CELANT, Germano. Art Povera: conceptual, actual or impossible art? London: Studio Vista, 1969.

CHEVALIER, Jean; GHEERBRANT, Alain. Dicionário de símbolos. Rio de Janeiro: José Olympio, 2018.

CHRISTOV-BAKARGIEV, Carolyn. Arte Povera. London: Phaidon, 2014.

CHIPP, Herschel. Teorias da arte moderna. São Paulo: Martins Fontes, 1988.

DAMISCH, Hubert. A theory of cloud: toward a history of painting. Stanford: Stanford University Press, 2002. 
DAMISCH, Hubert. Noab's Ark: essays on architecture. Cambridge: The MIT Press, 2016.

DANTO, Arthur C. A transfiguração do lugar-comum. São Paulo: Cosac Naify, 2005.

DIDI-HUBERMAN, Georges. Que emoção! Que emoção? São Paulo: Editora 34, 2016.

DIDI-HUBERMAN, Georges. Cascas. São Paulo: Editora 34, 2019.

ELIADE, Mircea. O sagrado e o profano: a essência das religiões. São Paulo: WMF Martins Fontes, 2019.

FARIAS, Agnaldo A. C. Esculpindo o espaço: a escultura contemporânea e a busca de novos modos de relação com o espaço. 1997. Tese (Doutorado em Arquitetura) - Faculdade de Arquitetura e Urbanismo, Universidade de São Paulo, São Paulo, 1997.

FEBVRE, Lucien; MARTIN, Henri-Jean. O aparecimento do livro. São Paulo: Edusp, 2017. FERREIRA, Glória; COTRIM, Cecília (Orgs.). Escritos de artistas: anos 60/70. Rio de Janeiro: Jorge Zahar, 2006.

FLUSSER, Vilém. A filosofia da caixa preta. Rio de Janeiro: Relume Dumará, 2002.

FLUSSER, Vilém. A dúvida. São Paulo: Annablume, 2011.

FOSTER, Hal. O retorno do real. São Paulo: Cosac Naify, 2014.

FOSTER, Hal. O complexo arte-arquitetura. São Paulo: Cosac Naify, 2015.

FOUCAULT, Michel. As palavras e as coisas: uma arqueologia das ciências humanas. São Paulo: Martins Fontes, 1999.

GODFREY, Mark. David Hammons: give me a moment. Athens: The George Economou Collection, 2016.

HARRISON, Charles; WOOD, Paul (Eds.). Art in theory 1900-2000: an anthology of changing ideas. Hoboken: Willey-Blackwell, 2003.

HARRISON, Charles; WOOD, Paul; GAIGER, Janson (Eds.). Art in theory 1648-1815: an anthology of changing ideas. Hoboken: Willey-Blackwell, 2003.

HARRISON, Charles; WOOD, Paul; GAIGER, Janson (Eds.). Art in theory 1815-1900: an anthology of changing ideas. Hoboken: Willey-Blackwell, 2003.

HUGO, Victor. O corcunda de Notre Dame. Rio de Janeiro: Jorge Zahar, 2013.

JUDD, Flavin; MURRAY, Caitlin (Eds.). Donald Fudd writings. New York: David Zwirner, 2016.

KANTOR, Tadeusz. O teatro da morte. São Paulo: Perspectiva: Sesc, 2008.

KAPROW, Allan. O legado de Jackson Pollock. In: FERREIRA, Glória; COTRIM, Cecília (Orgs.). Escritos de artistas: anos 60/70. Rio de Janeiro: Jorge Zahar, 2006. p. 37-45. KRAUSS, Rosalind. Sculpture in expanded field. October, Cambridge, v. 8, p. 30-44, 1979. KRAUSS, Rosalind. The originality of the Avant-Gard and other modernist myths. Cambridge: The MIT Press, 1996.

KRAUSS, Rosalind. Caminhos da escultura moderna. São Paulo: Martins Fontes, 1998.

KRAUSS, Rosalind. A voyage on the North Sea: art in the age of the post-medium condition. New York: Thames \& Hudson, 1999.

KRAUSS, Rosalind. Under blue cup. Cambridge: The MIT Press, 2011.

LICHTENSTEIN, Jacqueline (Org.). A pintura: textos essenciais. São Paulo: Editora 34, 2014. $14 \mathrm{v}$.

MADESTA, Andrea. Frammenti dell'Arte Povera: Jannis Kounellis und Mario Merz in der Sammlung Speck. Klagenfurt: Museum Moderner Kunst Kärnten, 2007. 
MAMMÌ, Lorenzo. O que resta: arte e crítica de arte. São Paulo: Companhia das Letras, 2012.

MORRIS, Robert. Have I reasons: work and writings, 1993-2007. Durham: Duke University Press, 2008.

MUNCH, Edvard. The mad author's journal MM T 2743. [S. l.: s. n.], 1909. Disponível em: https://emunch.no/TRANS_HYBRIDMM_T2734.xhtml. Acesso em: 2 fev. 2020.

PAIXÃO, Fernando. Arte da pequena reflexão: poema em prosa contemporâneo. São Paulo: Iluminuras, 2014.

PALLASMAA, Juhani. Los ojos de la piel: la arquitectura y los sentidos. Barcelona: Gustavo Gili, 2006.

PEREC, Georges. Especies de espacios. Barcelona: Montesinos, 2007.

POE, Edgar Allan. A filosofia da composição. In: POE, Edgar Allan. Poemas e ensaios. Rio de Janeiro: Globo, 1985. p. 17-34.

PONGE, Francis. O partido das coisas. São Paulo: Iluminuras, 2000.

PONGE, Francis. A mesa. São Paulo: Iluminuras, 2002.

RODIN, Auguste. Grandes catedrais. São Paulo: WMF Martins Fontes, 2002.

SEBALD, Winfried G. Austerlitz. São Paulo: Companhia das Letras, 2008.

SELBY, Aimee (Ed.). Art and text. London: Black Dog, 2009.

SERRA, Richard. Richard Serra: escritos e entrevistas, 1967-2013. São Paulo: IMS, 2014.

SHAPIRO, Meyer. A arte moderna: séculos XIX e XX. São Paulo: Edusp, 2010.

STANGOS, Nikos. Conceitos da arte moderna. Rio de Janeiro: Jorge Zahar, 2000.

STILES, Kristine; SELZ, Peter (Orgs.). Theories and documents of contemporary art. a sourcebook of artists' writings. Berkeley: University of California Press, 1996.

STOICHITA, Victor. Breve história da sombra. Lisboa: KKYM, 2016.

UMBERTO, Eco. Obra aberta. São Paulo: Perspectiva, 1991.

UMBERTO, Eco. Seis passeios pelos bosques da ficção. São Paulo: Companhia das Letras, 1994.

WOOD, James. A coisa mais próxima da vida. São Paulo: Sesi, 2017a.

WOOD, James. Como funciona a ficção. São Paulo: Sesi, $2017 \mathrm{~b}$. 


\section{Bibliografia específica sobre Jannis Kounellis}

BANN, Stephen. Fannis Kounellis. London: Reaktion Books, 2003.

BARRO, David; NAVAS, Adolfo M.; REIS, Paulo; PIOVANO, Rubens. Fannis Kounellis.

Rio de Janeiro: ARTEDARDO, 2008.

BERNABEI, Roberta. Fannis Kounellis. Roma: Editalia, 2012.

BEUYS, Joseph; CUCCHI, Enzo; KIEFER, Anselm; KOUNELLIS, Jannis. Bâtissons une cathédrale. entretien. Paris: L'Arche, 1986a.

BEUYS, Joseph; CUCCHI, Enzo; KIEFER, Anselm; KOUNELLIS, Jannis. The culturalhistorical tragedy of the European continent. Flash Art, Milano, n. 128, p. 36-39, 1986b.

BOATTO, Alberto. Kounellis: il giardino, i giuochi. Roma: Galleria L'Attico, 1967.

BONVICINI, Caterina; BRIGANTI, Giuliano. Fannis Kounellis edizioni. Roma: Galleria dell'Oca, 2007.

CASTAGNOLI, Pier Giovanni; PASSARELLA, Fabrizio. Kounellis: salara. Bologna: Comune di Bologna, 1995.

CELANT, Germano. Fannis Kounellis. Rimini: Musei Comunali, 1983.

CELANT, Germano. Kounellis. Milano: Skira Fabbri, 1992.

CELANT, Germano. Fannis Kounellis. Venezia: Fondazione Prada, 2019.

CICELYN, Eduardo; CODOGNATO, Mario. Fannis Kounellis: Museo Madre. Naples:

Madre, 2006.

COTTER, Suzanne; FUCHS, Rudi H.; NAIRNE, Andrew; ZEVI, Adachiara. Fannis Kounellis. Oxford: Modern Art Oxford, 2014.

CORÀ, Bruno. Burning is the image in the hour of the eclipse. Parkett, Zurich, n. 6, p. 21-43, 1985.

CORÀ, Bruno. Kounellis: Mistral. Bergamo: Bolis, 1996.

CORÀ, Bruno. Kounellis: Labirinti. Pistoia: Gli Ori, 2003.

CORÀ, Bruno. Fannis Kounellis - Sarajevo: Le Porte. Sarajevo: Pescara, 2004.

CORÀ, Bruno. Fannis Kounellis: atto unico. Firenze: Il Ponte, 2007a.

CORÀ, Bruno (Ed.). Fannis Kounellis: la storia e il presente. Pistoia: Gli Ori, 2007b.

CORÀ, Bruno. Fannis Kounellis en Santiago de Compostela. Santiago de Compostela: Fundación Caixa Galicia, 2008.

CORÀ, Bruno. Kounellis. Milano: Silvana, 2010.

CORÀ, Bruno (Ed.). Mafai Kounellis: la libertà del pittore. Pistoia: Gli Ori, 2014a.

CORÀ, Bruno. Fannis Kounellis. Milano: Silvana, 2014b.

CORÀ, Bruno; CICELYN, Eduardo; FUCHS, Rudi H.; RAUSSMÜLLER, Urs. Fannis Kounellis. Naples: Mag, 2016.

CORÀ, Bruno; GALGUERA, Hilario; GODOY, Dulce; LA TORRE, Carlos. Kounellis.

Ostfildern: Hatje Cantz, 2016.

DIACONO, Mario. Fannis Kounellis: “alfabeto”. Roma: Erco D'Aliberti, 1966.

DIACONO, Mario; KOUNELLIS, Jannis. MysticFicActions. Roma: [s. n.], 1963. 
DIACONO, Mario; KOUNELLIS, Jannis. Originali m'other. Roma: [s. n.], 1965.

FANELLI, Franco. Fannis Kounellis. Milano: Silvana, 2011.

FRÉMON, Jean. Fannis Kounellis. Paris: Galerie Lelong, 1989.

FRÉMON, Jean. Fannis Kounellis. Paris: Galerie Lelong, 1998.

FUCHS, Rudi H. Fannis Kounellis. Munich: Editions Schellmann, 1991.

FUCHS, Rudi H.; FROMENT, Jean-Louis. Fannis Kounellis. Bordeaux: CAPC Musé d'Art Contemporain, 1985.

FUCHS, Rudi H.; GACHNANG, Johannes; MUNDICI, Cristina. Fannis Kounellis. Milano: Fabbri, 1988.

HOET, Jean; ILLY, Andrea; IORI, Aldo; KAVAFIS, K. P.; ROELSTRAETE, Dieter. Fannis Kounellis. Milano: Charta, 2002.

HOLSTEN, Siegmar. Fannis Kounellis. Baden-Baden: Staatliche Kunsthalle, 1982.

KOLLER, Michael; LENSSEN, Jürgen (Eds.). Fannis Kounellis im Museum am Dom.

Würzburg: Museum am Dom, 2012.

KOUNELLIS, Jannis. Fannis Kounellis. Roma: Galleria L'Attico, 1967.

KOUNELLIS, Jannis. Kounellis. Naples: Lucio Amelio, 1980.

KOUNELLIS, Jannis. Hotel Louisiane. TAU MA, Bologna, n. 7, p. 61-71, 1981.

KOUNELLIS, Jannis. [Sem título]. Parkett, Zurich, n. 6, 1985.

KOUNELLIS, Jannis. Odyssée lagunaire. écrits et entretiens 1966-1989. Paris: Daniel Lelong, 1990.

KOUNELLIS, Jannis. Kounellis. Santa Monica: Jacob Samuel Editions, 1999.

KOUNELLIS, Jannis. Fannis Kounellis. Köln: Galerie Michael Werner, 2003.

KOUNELLIS, Jannis. Fannis Kounellis: senza titolo. London: Ivorypress, 2013.

KOUNELLIS, Jannis; BLOK, Aleksandr. Fannis Kounellis. Mönchengladbach: Städtisches Museum Mönchengladbach, 1978.

KOUNELlis, Jannis; CODOGNATO, Mario; D'ARGENZIO, Mirta. Echoes in the darkness: Jannis Kounellis writings and interviews 1966-2002. London: Trolley, 2002.

KOUNELLIS, Jannis; CORÀ, Bruno; FUCHS, Rudi H. Fannis Kounellis. London: Sprovieri, 2016.

KOUNELLIS, Jannis; FRÉMON, Jean; JUNCOSA, Enrique. Kounellis. Barcelona: Galeria Carles Taché, 2002.

KOUNELLIS, Jannis; FRIEDEL, Helmut; GROWE, Bernd; STOCKEBRAND, Marienne. Fannis Kounellis. Munich: Städtische Galerie im Lenbachhaus, 1985.

KOUNELLIS, Jannis; FUCHS, Rudi H. Fannis Kounellis. Eindhoven: The Van Abbemuseum, 1981.

KOUNELLIS, Jannis; GRÜTERICH, Marlis; AMMANN, Jean-Christophe. Fannis Kounellis. Pollenza: La Nuova Foglio Editrice, 1977.

KOUNELLIS, Jannis; HAENLEIN, Carl. Fannis Kounellis: frammenti di memoría. Hannover: Kestner-Gesellschaft, 1991.

KOUNELLIS, Jannis; JACOB, Mary Jane. Fannis Kounellis: a retrospective in five locations. Chicago: Museum of Contemporary Art (Chicago) \& Arnoldo Mondadori, 1986. 
KOUNELLIS, Jannis; LARRATT-SMITH, Philip; FUCHS, Rudi H. Fannis Kounellis.

London: Phaidon, 2019.

KOUNELLIS, Jannis; MOURE, Gloria. Fannis Kounellis: works, writings 1958-2000.

Barcelona: Polígrafa, 2001.

KOUNELLIS, Jannis; PARISI, Chiara. Fannis Kounellis. Ostfildern: Hatje Cantz, 2016.

LONZI, Carla. Kounellis. Milano: Galleria Dell'Ariete, 1967.

MOURE, Gloria (Ed.). Kounellis. New York: Rizzoli, 1990.

PARIS, Mathieu (Ed.). Fannis Kounellis. London: White Cube, 2017.

RENZITTI, Antonella. Kounellis: impronte. Pistoia: Gli Ori, 2017.

ROELSTRAETE, Dieter. Kounellis. Innsbruck: Galerie Elisabeth \& Klaus Thoman, 2004.

ROSENTHAL, Mark; FERGUSON, Bruce W.; CLADDERS, Johannes. Kounellis. Köln:

Galerie Karsten Greve, 2007.

SCHEIBLER, Victoria; DANCH, Kurt (Eds.). Fannis Kounellis. Cologne: Kunst-Station Sankt Peter, 2001.

SCHEPS, Marc. Fannis Kounellis: the gospel according to Thomas. Jaffa: Har-El, 2001.

SCHEPS, Marc. The odyssey of Kounellis the European. In: SCHNEIDER, Angela; DAEMGEN, Anke. Fannis Kounellis in the Neue National Galerie. Berlin: Hatje Cantz, 2008. p. $42-66$.

SCHEPS, Marc. Fannis Kounellis. Santander: Fundación Marcelino Botín, 2009.

SCHEPS, Marc. Kounellis stations on an odyssey. Munich: Prestel, 2010.

SCHNEIDER, Angela; DAEMGEN, Anke. Fannis Kounellis in the Neue National Galerie. Berlin: Hatje Cantz, 2008.

ULLRICH, Ferdinand. Fannis Kounellis: lineare notturno. Recklinghausen: Druck-und Verlagshaus Bitter, 1993.

VIVALDI, Cesare. F. Kounellis. Roma: La Tartaruga, 1964.

ZAZA, Giacomo. Fannis Kounellis. Molfetta: Torrione Pasari, 2003.

ZEVI, Adachiara. Fannis Kounellis: Santa Fe. Milano: Fondazione Achille e Giulia Boroli, 2005.

\section{Filmografia específica sobre Jannis Kounellis}

ARTIST Jannis Kounellis installing "Untitled 1984/87". Sidney: Art Gallery of NSW, 2011. 1 vídeo (1 min). Publicado pelo canal Art Galley of NSW. Disponível em: https:// bit.ly/39POdwr. Acesso em: 2 fev. 2020.

JANNIS Kounellis: atto único. Direção: Ermanno Olmi. [S. l:: s. n.], 2006. 1 vídeo (41 min). Disponível em: https://bit.ly/2HDOrL1. Acesso em: 2 fev. 2020.

JANNIS Kounellis. Louisiana: Louisiana Channel, 2015. 1 vídeo (20 min). Publicado pelo canal Louisiana Channel. Disponível em: https://bit.ly/37JX115. Acesso em: 2 fev. 2020. 


\section{Outros textos de Jannis Kounellis não incluídos neste trabalho}

KOUNELLIS, Jannis. Per catalogo prima pagina oscuro. In: KOUNELLIS, Jannis et al. Processi di pensiero visualizzati: Junge italienische Avantgarde. Lucerne: Kunstmuseum, 1970.

KOUNELLIS, Jannis. La via del sangue. Roma: Galleria La Salita, 1973. (Collana de Perle, 4).

KOUNELIS, Jannis. Warm gibt's keinen Mondrian unter den Spaniern? In: A D A 2. Aktionen der Avantgarde: Dokumentation der Projekte von Amelith, Buren, Canogar, Gerz, Kaemmerling, Kienholz, Kounellis, Vostell. Berlim: Neuer Berliner Kunstverein, 1975.

KOUNELLIS, Jannis. Cavolo! Che bella donna! La città di Riga, Pollenza, n. 1, p. 43-49, 1976. [Disponível em português: KOUNELLIS, Jannis. Sem título no 7. In: FERREIRA, Glória; COTRIM, Cecília (Orgs.). Escritos de artistas: anos 60/70. Rio de Janeiro: Jorge Zahar, 2006. p. 364-373].

KOUNELLIS, Jannis. Probabilmente è vero. In: PROGETTO Genazzano. Genazzano: La Zattera di Babele, 1983.

KOUNELLIS, Jannis. Aderisco alla problemática. Il Manifesto del Mese, Roma, n. 4, p. 50$51,1992$.

KOUNELLIS, Jannis. Questo lavoro esposto. In: CAVALLUCCI, Fabio (Ed.). Tuscia electa: 14 artisti internazionali in Toscana. Torino: Hopefulmonster, 1996. p. 58.

KOUNELLIS, Jannis. Für eine noch mögliche Lehre. In: GOSTOVANJE studenata sa Kunstakademie-Düsseldorf u Salonu muzej suvremene umetnosti u Beogradu. Belgrado: Salon Muzej Suvremene Umenosti, 1997.

KOUNELLIS, Jannis. Centralità della forma. In: CORÀ, Bruno; BRUNO, Raffaele (Eds.). Tempo e forma nell'arte contemporanea: atti del convegno-esposizione internazionale Cassino, 13-15 maggio 1996. Cassino: Università degli Studi, 1998. p. 37-39.

KOUNELLIS, Jannis. La storia non conosce negazioni. In: FICACCI, Luigi (Ed.). Tirannicidi (il disegno). Roma: Calcografia Nazionale: Istituto Nazionale per la Grafica, 2000. p. 21-23.

KOUNELLIS, Jannis. Senza titolo. In: KOUNELLIS. Prato: Gli Ori, 2001.

KOUNELLIS, Jannis. Senza titolo. In: KOUNELLIS ai Bottini dell'Olio. Livorno: Comune di Livorno, 2001.

KOUNELLIS, Jannis. Senza titolo. In: KOUNELLIS. Barcelona: Galeria Carles Taché, 2002.

KOUNELLIS, Jannis. Senza titolo. In: JANNIS Kounellis. Molfetta: 2003.

KOUNELLIS, Jannis. Senza titolo. In: CORÀ, Bruno; FALLETI, Franca; D'AFFLITTO,

Chiara (Eds.). Forme per il David. Florence: Giunti, 2004.

KOUNELLIS, Jannis. Senza titolo. In: KOUNELLIS. Atenas: K. Adam, 2006. 
KOUNELLIS, Jannis. Senza titolo. In: REENBERG, Holger (Ed.). Kounellis: Frihed eller døden. Herning: Heart, 2009.

KOUNNELIS, Jannis. Senza titolo. In: FANELLI, Franco (Ed.). Fannis Kounellis. Milano: Silvana, 2010.

KOUNELLIS, Jannis. Senza titolo. In: JANNIS Kounellis “Atto Unico" Mosca-Nizhny Novgorod. Roma: Centro Nazionale di Arte Contemporanea: RAM Live, 2012.

KOUNELLIS, Jannis. Senza titolo. In: JANNIS Kounellis. Berlin: Jovis, 2012.

KOUNELLIS, Jannis. Senza titolo. Mozart, [S. l.], n. 2, p. 6, 2012.

KOUNELLIS, Jannis. Senza titolo. In: IMPONENTE, Anna; SALDARI, Eloisa (Eds.). About Caravaggio: visioni e illusioni contemporanea. Turim: Umberto Allamandi, 2013.

KOUNELLIS, Jannis. Senza titolo. In: TRIONE, Vicenzo (Ed.). Post-classici: la ripresa dell'antico nell'arte contemporanea italiana. Milano: Mondadori Electa, 2013.

KOUNELLIS, Jannis. Senza titolo. In: JANNIS Kounellis. Imola: Manfredi Edizioni, 2015. 

